$$
\operatorname{Pontifícia~}_{\text {Universidade }_{\text {do Rio de Janeiro }}}
$$

Eric Vallotti Pereira

Influência de Fibras de Aço no Comportamento Mecânico e nos Mecanismos de Fissuração de Concretos Autoadensáveis

Dissertação de Mestrado

Dissertação apresentada ao Programa de Pós-graduação em Engenharia Civil da PUC-Rio como requisito parcial para obtenção do grau de Mestre em Engenharia Civil.

Orientador: Prof. Flávio de Andrade Silva 


$$
\operatorname{Pontifícia~}_{\text {Universidade }_{\text {do Rio de Janeiro }}}
$$

Eric Vallotti Pereira

\section{Influência de Fibras de Aço no Comportamento Mecânico e nos Mecanismos de Fissuração de Concretos Autoadensáveis}

Dissertação apresentada como requisito parcial para obtenção do grau de Mestre pelo Programa de Pósgraduação em Engenharia Civil da PUC-Rio. Aprovada pela Comissão Examinadora abaixo assinada.

Prof. Flávio de Andrade Silva Orientador

Departamento de Engenharia Civil e Ambiental - PUC-Rio

Prof. Daniel Carlos Taissum Cardoso

Departamento de Engenharia Civil e Ambiental - PUC-Rio

Prof. Conrado de Souza Rodrigues

Centro Federal de Educação Tecnológica de Minas Gerais

Prof. Marcio da Silveira Carvalho Coordenador Setorial do Centro Técnico Científico - PUC-Rio 
Todos os direitos reservados. É proibida a reprodução total ou parcial do trabalho sem autorização da universidade, do autor e do orientador.

\section{Eric Vallotti Pereira}

Graduou-se em Engenharia Civil na UFJF (Universidade Federal de Juiz de Fora) em 2012.

Ficha Catalográfica

Pereira, Eric Vallotti

Influência de fibras de aço no comportamento mecânico e nos mecanismos de fissuração de concretos autoadensáveis / Eric Vallotti Pereira ; orientador: Flávio de Andrade Silva. - 2017.

170 f. : il. color. ; $30 \mathrm{~cm}$

Dissertação (mestrado)-Pontifícia Universidade Católica do Rio de Janeiro, Departamento de Engenharia Civil e Ambiental, 2017.

Inclui bibliografia

1. Engenharia Civil e Ambiental - Teses. 2. Concreto reforçado com fibras de aço. 3. Concreto autoadensável. 4. Fibras de aço. 5. Comportamento mecânico. 6. Comportamento estrutural. I. Silva, Flávio de Andrade. II. Pontifícia Universidade Católica do Rio de Janeiro. Departamento de Engenharia Civil e Ambiental. III. Título. 
Aos meus pais, José Carlos e Angela Maria, pelo apoio e incentivo. 


\section{Agradecimentos}

Os maiores incentivadores para meu ingresso no Mestrado foram meus pais, José Carlos Pereira e Angela Maria Vallotti Pereira, cujo apoio e incentivo sempre foram determinantes em toda a minha vida. Também destaco o apoio e carinho da minha irmã Renata Vallotti Pereira e de toda família.

Também agradeço às pessoas que me ajudaram a superar os desafios que antecederam o ingresso na pós-graduação da PUC-Rio. São eles os professores da Universidade Federal de Juiz de Fora e os amigos que obtive durante a carreira de Engenheiro Civil: Adriano Campos e Sérgio de Oliveira Pregnolato.

Agradeço imensamente ao meu amigo Vinícius Feitosa Pimenta e a sua esposa Mariana Monnerat, pelo apoio oferecido quando da minha chegada ao Rio de Janeiro.

Agradeço ao meu orientador Flávio de Andrade Silva, por todos os recursos disponibilizados, pela confiança e apoio concedido até a conclusão deste trabalho.

Agradeço ao técnico Euclides Domingues de Moura Neto por todo auxílio prestado na instrumentação de ensaios e na operação das máquinas de testes do Laboratório de Estruturas e Materiais da PUC-Rio.

Agradeço aos alunos de Iniciação Científica, Gabriel Bernardo Saraiva Pereira e Vítor Moreira de Alencar Monteiro, por me auxiliarem por diversas vezes.

Por fim, agradeço a todos os demais professores, técnicos, funcionários e colegas da PUC-Rio, que me deram suporte até conclusão deste trabalho. 


\section{Resumo}

Pereira, Eric Vallotti; Silva, Flávio de Andrade. Influência de Fibras de Aço no Comportamento Mecânico e nos Mecanismos de Fissuração de Concretos Autoadensáveis. Rio de Janeiro, 2017. 170p. Dissertação de Mestrado - Departamento de Engenharia Civil e Ambiental, Pontifícia Universidade Católica do Rio de Janeiro.

No presente trabalho foi investigado o comportamento mecânico de um concreto autoadensável reforçado com fibras de aço. Foram utilizadas fibras de aço torcidas e com ganchos, nos comprimentos de 25,30 e $60 \mathrm{~mm}$ e diâmetros de 0,5, 0,62 e 0,75 mm. Para cada uma destas fibras e para cada uma das frações volumétricas investigadas $(0,5,1,0$ e 2,0\%) foram realizados os ensaios de flexão em quatro pontos em corpos de prova prismáticos e de tração direta em corpos de prova do tipo dog bone shaped. Nos ensaios de flexão, os índices de tenacidade e as cargas residuais foram contabilizados. Alternativamente, determinou-se a energia absorvida nos ensaios de flexão de painéis circulares conforme a ASTM C1550, cuja abertura de fissuras foi medida com o auxílio de transdutores de deslocamento. Os corpos de prova reforçados com fibras de aço submetidos à tração direta se mostraram mais dúcteis com relação à matriz de concreto autoadensável, observando-se grande influência do volume e comprimento ancorado das fibras nas cargas residuais da zona de pós-fissuração. Nos ensaios de flexão, observaram-se grandes incrementos na tenacidade e deformações correspondentes às cargas residuais. Por fim, analisou-se a influência desses concretos no comportamento de vigas armadas sujeitas à flexão. A evolução da abertura de fissuras foi monitorada com sistema de correlação digital de imagens, sendo posteriormente correlacionadas com cargas aplicadas e com os deslocamentos obtidos nos ensaios. Observou-se nestes ensaios, que o reforço fibroso aumentou a capacidade de carga e a rigidez à flexão, atrasando consideravelmente o surgimento de fissuras.

\section{Palavas-chave}

Concreto reforçado com fibras de aço; concreto autoadensável; fibras de aço; comportamento mecânico; comportamento estrutural. 


\section{Abstract}

Pereira, Eric Vallotti; Silva, Flávio de Andrade (Advisor). Influence of Steel fibers in the Mechanical Behavior and Cracking Mechanisms of Self-Consolidating Concretes. Rio de Janeiro, 2017. 170p. Dissertação de Mestrado - Departamento de Engenharia Civil e Ambiental, Pontifícia Universidade Católica do Rio de Janeiro.

In the present work the mechanical behavior of a self-consolidating concrete reinforced with steel fibers was investigated. Twisted and hooked end steel fibers were used in lengths of 25,30 and $60 \mathrm{~mm}$ and diameters of $0.5,0.62$ e $0.75 \mathrm{~mm}$. For each of these fibers and for each volumetric fractions investigated $(0.5,1.0$ and $2.0 \%$ ), the four-point bending tests on prismatic specimens and direct tensile in dog bone shape specimens were performed. In the flexural tests, the toughness and residual strengths were computed. Alternatively, the energy absorption capacity in the round panel tests was determined following the ASTM C1550. During the test the crack opening was measured through displacement transducers. The steel fiber reinforced concrete subject to direct tensile loading was more ductile than the self-consolidating concrete matrix, showing a high influence of the volume and embedded length of the fibers in the residual loads in the post-cracking zone. In the bending tests, a large increase in the toughness and strains corresponding to the residual loads were observed. Finally, the influence of the fiber reinforced concretes on the behavior of reinforced beams subject to bending was investigated. The evolution of the crack openings was monitored with a digital image correlation system and correlated to the applied load and displacements. It was observed in these tests that the fibrous reinforcement considerably increased the load capacity and flexural stiffness, delaying the crack growth.

\section{Keywords}

Steel fiber reinforced concrete; self-consolidating concrete; steel fibers; mechanical behavior; structural behavior. 


\section{Sumário}

1 Introdução 25

$\begin{array}{ll}\text { 1.1 Motivação e objetivos } & 27\end{array}$

1.2 Estrutura do trabalho 28

2 Revisão da literatura $\quad 29$

2.1 Perspectiva histórica sobre a tecnologia do concreto 29

2.2 Concretos reforçados com fibras de aço 31

2.3 Tipos de fibras de aço 32

2.4 Propriedades dos concretos reforçados com fibras de aço 34

2.4.1 Propriedades dos SFRSCCs no estado fresco 34

2.4.2 Propriedades dos SFRSCCs no estado endurecido 38

2.4.3 Mecanismos de pré e pós-fissuração $\quad 40$

2.4.4 Zona de transição interfacial 48

2.4.5 Mecanismos de transferência de tensões 50

2.4.6 Mecanismos de fissuração $\quad 56$

2.4.7 Comportamento à compressão $\quad 59$

2.4.8 Comportamento à tração 62

2.4.9 Comportamento à Flexão 71

2.4.10 Comportamento de elementos estruturais à flexão 74

3 Programa experimental $\quad 79$

$\begin{array}{ll}3.1 \text { Introdução } & 79\end{array}$

$\begin{array}{ll}\text { 3.2 Materiais utilizados } & 81\end{array}$

$\begin{array}{ll}\text { 3.2.1 Material cimentício } & 81\end{array}$

$\begin{array}{ll}3.2 .2 \text { Agregados } & 81\end{array}$

$\begin{array}{ll}3.2 .3 \text { Adições } & 81\end{array}$ 
3.2.4 Aditivo $\quad 82$

3.2.5 Fibras de aço $\quad 82$

3.3 Ajuste para produção do concreto autoadensável 83

3.4 Ensaios do programa experimental 85

3.4.1 Ensaios na escala do material 85

3.4.2 Ensaios semiestruturais 93

3.4.3 Ensaios estruturais 96

4 Resultados e análises 100

4.1 Ensaios na escala do material 100

4.1.1 Determinação do espalhamento e do tempo de escoamento 100

4.1.2 Determinação da resistência e do módulo à compressão axial 104

4.1.3 Determinação da resistência à tração direta 105

4.1.4 Determinação da resistência à tração na flexão 114

4.2 Ensaios semiestruturais 122

4.2.1 Ensaios de flexão em painéis circulares 122

$\begin{array}{ll}\text { 4.3 Ensaios estruturais } & 129\end{array}$

4.3.1 Ensaios em vigas curtas armadas $\quad 129$

4.3.2 Cálculo da capacidade de carga das vigas armadas e reforçadas 140

5 Conclusões

6 Referências bibliográficas 150

7 ANEXOS 160

7.1 ANEXO I - Resultados individuais dos ensaios 161

7.2 ANEXO II - Fotomontagem dos corpos de prova ensaiados 164 


\section{Lista de figuras}

Figura 1 - Tipos de fibras de aço e seções transversais típicas.

Figura 2 - Comportamento geral ao arrancamento de fibras torcidas, com ganhos e lisas; adaptado de [41].

Figura 3 - Arranjos espaciais de fibras idealizados

Figura 4 - Modelo para distribuição das tensões em função do comprimento crítico de fibras retas e lisas; adaptado de Brandt [42]

Figura 5 - Figura esquemática da microestrutura formada na vizinhança das fibras de aço; adaptado de [16, 47]

Figura 6 - llustração: a) da fibra de geometria simples utilizada nos modelos; b) da distribuição de tensões nas fibras de aço assumida para uma matriz perfeitamente elástica; c) dos arranjos espaciais quadrados e hexagonais; adaptado de $[49,16]$

Figura 7 - Modelos da distribuição de tensões cisalhantes na fibra em compósito: a) íntegro; b) fissurado; adaptado de Bentur \& Mindess [16].

Figura 8 - llustração: a) dos modelos que descrevem as tensões cisalhantes ao longo das fibras; adaptado de Li \& Stang [51]; b) dos intervalos que descrevem as relações de tensões cisalhantes adesionais e friccionais; adaptado de Bentur \& Mindess [16].

Figura 9 - llustração: a) do modelo de arrancamento com escorregamento de fibras lisas adaptado de Naaman et al. [50]; b) de um gráfico típico de tensão adesional versus deslocamento com decaimento friccional, adaptado de Naaman et al. [50]; c) de 
um gráfico típico de arrancamento versus deslizamento, adaptado de Alwan et al. [53]; d) da contribuição adesional e friccional da força total e da energia de arrancamento adaptado de Bentur et al. [52]

Figura 10 - Curva típica dos ensaios carga versus deslizamento das fibras de aço; adaptado de [16, 54].

Figura 11 - llustração: a) do processo de dano na matriz em fibras sujeitas à tração; b) do processo de fratura na matriz quando as fibras são sujeitas ao cisalhamento e flexão; adaptado de [54, 16]

Figura 12 - Detalhe esquemático do comportamento dos SFRCs à tração; adaptado de Li et al. [57].

Figura 13 - Detalhe esquemático do efeito das pontes de fibras e agregados no processo de fratura dos SFRCs à tração adaptado de $[65,47,55]$.

Figura 14 - Gráfico esquemático dos concretos comuns e reforçados com fibras sobre compressão axial; adaptado de [9, $16,65,66]$.

Figura 15 - Gráficos tensão-deformação à compressão para observação da influência do volume e razão de aspecto das fibras de aço; adaptado da ACI 544.4R [40].

Figura 16 - Comportamento típico dos FRCs e HPFRCCs sob tração direta; adaptado de [67, 84, 83].

Figura 17 - Classificação dos FRCs baseada no comportamento à tração como de alto desemprenho ou dúctil; adaptado de Naaman \& Reinhardt [92]. 
Figura 18 - Gráfico: a) da distribuição granulométrica dos agregados; b) da distribuição granulométrica das adições

Figura 19 - Geometria das fibras de aço utilizadas

Figura 20 - Índices de fluidez da argamassa do traço para volumes crescentes de aditivo superplastificante

Figura 21 - Fases do programa experimental

Figura 22 - Ilustração: a) das dimensões do cone de Abrams; b) da placa base para ensaio de espalhamento

Figura 23 - llustração: a) do corpo de prova do tipo dog bone shaped; b) das partes da fôrma bipartida; c) das partes $A / B$ da fôrma bipartida

Figura 24 - llustração: a) da máquina retífica adaptada; b) da marcação de centro; c) da perfuração; d) do corte das barras de aço; e) da montagem do aparato para ensaio

Figura 25 - Máquina de ensaios e aparato utilizados nos ensaios de tração direta

Figura 26 - Detalhe do corpo de prova prismático e das marcações efetuadas.

Figura 27 - Detalhe da montagem do ensaio de flexão em quatro pontos

Figura 28 - Detalhe do pórtico rígido utilizado nos ensaios de flexão de corpos de prova prismáticos

Figura 29 - llustração: a) do painel circular com LVDTs e pontos de apoio colados; b) das marcações de pontos chave 
Figura 30 - llustração: $a-b)$ detalhes da disposição dos transdutores

Figura 31 - Detalhe de um painel circular posicionado na máquina de ensaios

Figura 32 - Detalhe das armaduras e de montagem dos ensaios de flexão em vigas armadas

Figura 33 - Detalhe do pórtico rígido utilizado nos ensaios de flexão em vigas armadas

Figura 34 - Detalhe da pintura base para monitoramento por sistema de correlação digital de imagens (DIC).

Figura 35 - Gráfico: a) comparativo dos espalhamentos em função da frações volumétricas de fibras; b) comparativo dos tempos de escoamento em função das frações volumétricas de fibras

Figura 36 - Fotografia: a) da placa base e do cone de Abrams na posição invertida; b) da borda da matriz de concreto autoadensável; c) do concreto reforçado com a fração volumétrica de $0,5 \%$ de fibras com ganchos de $30 \mathrm{~mm}$ e razão de aspecto 45 ; d) da borda do autoadensável reforçado com fibras de aço.

Figura 37 - Fotografia: a) do concreto autoadensável reforçado com a fração volumétrica de $1,0 \%$ de fibras torcidas de comprimento $25 \mathrm{~mm}$ e razão de aspecto 50 ; b) do concreto autoadensável reforçado com a fração volumétrica de $2,0 \%$ de fibras torcidas de comprimento $25 \mathrm{~mm}$ e razão de aspecto 50 ; c) do concreto com a fração volumétrica de $1,0 \%$ de fibras com ganchos de comprimento $60 \mathrm{~mm}$ e razão de aspecto 80; d) do concreto reforçado com fibras com as fibras de "c", mas com a fração volumétrica de 2,0 \% 
Figura 38 - Gráfico tensão-deformação à tração direta da matriz de concreto autoadensável

Figura 39 - Gráfico: a-c) tensão-deformação à tração direta dos concretos reforçados com fibras torcidas de razão de aspecto 50 e comprimento $25 \mathrm{~mm}$, nas frações volumétricas de 0,5, 1,0 e $2,0 \%$, respectivamente; d) comparativo de tenacidadedeformação médios à tração direta dos mesmos concretos de "ac"

Figura 40 - Gráfico: a-c) tensão-deformação à tração direta de corpos de prova dog bone shaped moldados com concreto reforçado com fibras providas de ganchos nas extremidades com razão de aspecto 45 e comprimento $30 \mathrm{~mm}$, nas frações volumétricas de 0,5, 1,0 e 2,0\%, respectivamente; d) comparativo de tenacidade-deformação médios à tração direta dos mesmos concretos de "a-c"

Figura 41 - Gráfico: a-c) tensão-deformação à tração direta de corpos de prova dog bone shaped moldados com concreto reforçado com fibras providas de ganchos nas extremidades com razão de aspecto 80 e comprimento $60 \mathrm{~mm}$, nas frações volumétricas de $0,5,1,0$ e 2,0 \%, respectivamente; d) comparativo de tenacidade-deformação médios à tração direta dos mesmos concretos de "a-c"

Figura 42 - Detalhe da seção rompida do corpo de prova HE $80 / 60-2 \%$, CP 1

Figura 43 - Gráfico de resistências residuais na deformação de $0,5 \%$, com relação à de primeira fissura 
Figura 44 - Gráfico: a-c) tenacidade-deformação médios à tração direta de concretos reforçados com diferentes fibras de aço, em frações volumétricas crescentes

Figura 45 - Gráfico tensão-deformação à flexão da matriz de concreto autoadensável;

Figura 46 - Gráfico a-c) carga-deslocamento à flexão de concretos reforçados com fibras torcidas de razão de aspecto 50 e comprimento $25 \mathrm{~mm}$, nas frações volumétricas de 0,5, 1,0 e $2,0 \%$, respectivamente; d) comparativo de energia-deslocamento médios à flexão dos mesmos concretos de "a-c"

Figura 47 - Gráfico: a-c) carga-deslocamento à flexão de corpos de prova prismáticos moldados com concreto reforçado com fibras providas de ganchos com razão de aspecto 45 e comprimento $30 \mathrm{~mm}$, nas frações volumétricas de $0,5,1,0$ e 2,0\%, respectivamente; d) comparativo de energia-deslocamento médios à flexão dos mesmos concretos de "a-c"

Figura 48 - Gráfico: a-c) carga-deslocamento à flexão de corpos de prova prismáticos moldados com concreto reforçado com fibras providas de ganchos com razão de aspecto 80 e comprimento $60 \mathrm{~mm}$, nas frações volumétricas de $0,5,1,0$ e 2,0\%, respectivamente; d) comparativo de energia-deslocamento médios à flexão dos mesmos concretos de "a-c"

Figura 49 - Gráfico de resistências residuais na deflexão de 1 $\mathrm{mm}$, com relação à de primeira fissura

Figura 50 - Gráfico de resistências residuais na deflexão de 2 $\mathrm{mm}$, com relação à de primeira fissura 
Figura 51 - Gráfico: a-c) energia-deslocamento médios à flexão de concretos reforçados com diferentes fibras de aço, em frações volumétricas crescentes

Figura 52 - Gráfico carga-deslocamento à flexão de painéis circulares moldados com: a) matriz de concreto autoadensável; bd) concreto autoadensável reforçado com fibras de aço providas de ganchos de razão de aspecto 45 e comprimento $30 \mathrm{~mm}$, nas frações volumétricas de 0,5, 1,0 e 2,0\%, respectivamente

Figura 53 - Gráficos carga-deslocamento à flexão de painéis circulares moldados com concreto autoadensável reforçado com a fração volumétrica de 2,0 \% de fibras de aço do tipo: a) torcidas de razão de aspecto 50 e comprimento $25 \mathrm{~mm}$; b) fibras com ganchos de razão de aspecto 45 e comprimento $30 \mathrm{~mm}$; c) fibras com ganchos de razão de aspecto 80 e comprimento $60 \mathrm{~mm}$

125

Figura 54 - Gráfico: a) de resistências residuais na deflexão de 5 $\mathrm{mm}$, com relação à de primeira fissura; b) de resistências residuais na deflexão de $10 \mathrm{~mm}$, com relação à de primeira fissura

Figura 55 - Gráfico: a) energia-deslocamento médios à flexão de painéis circulares moldados com concreto autoadensável reforçado com fibras de razão de aspecto 45 e comprimento 30 $\mathrm{mm}$ nas frações volumétricas de 0,5, 1,0 e 2,0\%; b) comparativo de energia-deformação à flexão de painéis circulares moldados com concreto autoadensável reforçado com as diferentes de fibras utilizadas, na fração volumétrica de 2,0 \%

Figura 56 - Gráficos a-b) carga-abertura de fissuras à flexão de painéis circulares moldados com concreto autoadensável reforçado com fibras de aço providas de ganchos de razão de aspecto 45 e comprimento $30 \mathrm{~mm}$, nas frações volumétricas de $0,5,1,0 \%$, respectivamente 
Figura 57 - Gráficos carga-abertura de fissuras à flexão de painéis circulares moldados com concreto autoadensável reforçado com a fração volumétrica de $2,0 \%$ de fibras de aço do tipo: a) torcidas de razão de aspecto 50 e comprimento $25 \mathrm{~mm}$; b) fibras com ganchos de razão de aspecto 45 e comprimento $30 \mathrm{~mm}$; c) fibras com ganchos de razão de aspecto 80 e comprimento $60 \mathrm{~mm}$

Figura 58 - llustração: a) do modo de ruptura esperado (ASTM C 1550 [3]); b) do outro modo de ruptura observado nos ensaios de flexão em painéis circulares

Figura 59 - Gráficos carga-deslocamento à flexão de vigas armadas com pares barras de aço de 6.3, 8.0 e $10 \mathrm{~mm}$ e moldadas com: a) matriz de concreto autoadensável; b) concreto autoadensável reforçado com fibras de aço com ganchos de razão de aspecto 45 e comprimento $30 \mathrm{~mm}$, na fração volumétrica de $2,0 \%$

Figura 60 - llustração: a) do detalhe da viga armada sob flexão; b) do modelo utilizado para cálculo dos gráficos momento-curvatura; c) do gráfico momento-curvatura típico

Figura 61 - Gráfico: a) momento-curvatura de vigas moldadas com a matriz de concreto autoadensável e armadas com pares de barras de 6,3, 8,0 e 10,0 mm; b) do trecho inicial da curva "a"; c) momento-curvatura de vigas armadas e reforçadas com concreto autoadensável contendo a fração volumétrica de 2,0\% de fibras com ganchos de comprimento $30 \mathrm{~mm}$ e razão de aspecto 45 ; d) do trecho inicial da curva "c"

Figura 62 - Gráficos rigidez-momento de vigas armadas com pares barras de aço de 6.3, 8.0 e $10 \mathrm{~mm}$ e moldadas com: a) matriz de concreto autoadensável; b) concreto autoadensável 
reforçado com fibras de aço com ganchos de razão de aspecto 45 e comprimento $30 \mathrm{~mm}$, na fração volumétrica de 2,0 \%

Figura 63 - Gráficos deformação-distância de vigas armadas com um par de barras de $10 \mathrm{~mm}$ para: a) uma linha que passa na altura do eixo das barras de aço; b) a região inteira monitorada pelo sistema de correlação digital de imagens (DIC)

Figura 64 - Gráficos comparativos de deformação-distância de vigas armadas com um par de barras de $8.0 \mathrm{~mm}$ : a-b) sem reforço fibroso; b-d) com reforço de 2,0 \% de fibras de aço de aspecto 45 e comprimento $30 \mathrm{~mm}$

Figura 65 - Gráficos comparativos de deformação-distância de vigas armadas com um par de barras de $6.3 \mathrm{~mm}$ : a-b) sem reforço fibroso; b-d) com reforço de 2,0 \% de fibras de aço de aspecto 45 e comprimento $30 \mathrm{~mm}$

Figura 66 - Leis constitutivas dos SFRCs em termos de $\sigma-\varepsilon$ e $\sigma-w$

Figura 67 - Considerações de projeto para análise de vigas concreto armado contendo fibras de aço; adaptado da ACI 544.4R [40]

Figura 68 - Leis constitutivas do concreto reforçado com fibras de aço com base nas recomendações do RILEM TC 162-TDF [97]

Figura 69 - Ilustração: a) do detalhe da reta paralela ao período inicial elástico do gráfico carga-deflexão utilizada para interceptar a curva e determinar a carga máxima $\mathrm{F}_{\mathrm{u}}$; $\mathrm{b}-\mathrm{c}$ ) da contribuição das fibras na capacidade de absorção de energia; d) das distribuições de tensões simplificadas; adaptado do RILEM TC 162-TDF [97] 
Figura 70 - Gráficos carga-deslocamento à flexão de um único corpo de prova prismático de $150 \times 150 \times 500 \mathrm{~mm}$ com entalhe de espessura $3 \mathrm{~mm}$ e profundidade $25 \mathrm{~mm}$, contendo: a) detalhe da reta paralela ao trecho elástico do gráfico carga-deslocamento; bc) detalhes das áreas utilizadas para cálculo das forças residuais equivalentes

Figura 71 - Fotomontagem dos corpos de prova tipo dog bone shaped ensaiados à tração direta: séries CAA - 0\% e TW 50/25

Figura 72 - Fotomontagem dos corpos de prova tipo dog bone shaped ensaiados à tração direta: séries HE 45/30 e HE 80/60

Figura 73 - Fotomontagem dos corpos de prova prismáticos ensaiados à flexão: séries CAA - 0\% e TW 50/25

Figura 74 - Fotomontagem dos corpos de prova prismáticos ensaios à flexão: séries HE 45/30 e HE 80/60

Figura 75 - Fotomontagem dos painéis circulares ensaiados à flexão: séries CAA - 0\% e HE 45/30 - 0,5\%

Figura 76 - Fotomontagem dos painéis circulares ensaiados à flexão: séries HE 45/30 - 1,0\% e HE 45/30 - 2,0\%

Figura 77 - Fotomontagem dos painéis circulares ensaiados à flexão: séries TW 50/25 - 2,0\% e HE 80/50 - 2,0\% 


\section{Lista de tabelas}

Tabela 1 - Configurações típicas dos ensaios de tração direta com amostras tipo dog bone shaped; adaptado de [78]

Tabela 2 - Configurações típicas dos ensaios de tração direta com amostras cilíndricas/prismáticas: a) sem entalhe; b) com entalhe; adaptado de [78]

Tabela 3 - Propriedades das fibras de aço utilizadas

Tabela 4 - Traço do concreto autoadensável

Tabela 5 - Métodos de ensaio e universo amostral

Tabela 6 - Parâmetros do ensaio de tração direta

Tabela 7 - Parâmetros do ensaio de flexão em corpos de prova prismáticos

Tabela 8 - Parâmetros do ensaio de flexão em painéis circulares

Tabela 9 - Parâmetros do ensaio de flexão em vigas armadas

Tabela 10 - Resumo dos resultados dos ensaios de espalhamento modificado

Tabela 11 - Resumo dos resultados dos ensaios de resistência e módulo elástico à compressão axial do concreto de referência

Tabela 12 - Resumo dos resultados dos ensaios de resistência e módulo elástico à compressão axial da série HE 4530 - 2\% 
Tabela 15 - Resumo das resistências e energias de deformação médios à flexão de corpos de prova prismáticos

Tabela 16 - Resumo dos resultados de flexão em painéis circulares

Tabela 17 - Valores característicos individuais à flexão de vigas

Tabela 19 - Resumo das resistências individuais dos ensaios de tração direta

Tabela 20 - Resumo dos resistências individuais dos ensaios de flexão em corpos de prova prismáticos

Tabela 21 - Resumo dos resultados individuais à flexão de painéis circulares 


\section{Lista de símbolos e abreviaturas}

Abreviaturas

$\mathrm{a} / \mathrm{c}$

Relação entre os conteúdos de água e cimento, em massa.

DIC

Digital Image Correlation (Correlação digital de imagens).

DSP

Densified Cement Ultra-fine Particle-based Materials

ECC

Engineered Cementitious Composites.

FRC

Fibre-Reinforced Concrete (Concreto Reforçado com Fibras).

FRCC

Fibre-Reinforced Cement Composite (Compósito Cimentício Reforçado com Fibras).

GFRC

Glass Fiber-Reinforced Concrete (Concreto Reforçado com Fibras de Vidro).

HFRC

Hybrid Fiber Reinforced concrete.

HPFRCC

High-Performance Fibre-Reinforced Cement Composite (Compósito Cimentício Reforçado com Fibras de Alto Desempenho).

HPSFRC

High-Performance Steel Fibre-Reinforced Concrete (Concreto Reforçado com Fibras de Aço de Alto Desempenho. 
HSC

ITZ

LWAC

NFRC

RPC

SCC

SCHPFRC

SFRC

SFRSCC

SIFCON

SIMCON

SNFRC
High-Strength Concrete (Concreto Concreto de Alta Resistência).

Interfacial Transition Zone (Zona de Transição Interfacial.

Light Weight Aggregate Concrete (Concreto Leve).

Natural Fiber-Reinforced Concrete (Concreto Reforçado com Fibras Naturais).

Reactive Powder Concretes (Concretos de Pós Reativos).

Self-Compacting

Concrete

(Concreto

Autoadensável).

Self-consolidating High Performance Fiber Reinforced Concrete (Concreto Autoadensável de Alto Desempenho Reforçado com Fibras).

Steel Fibre-Reinforced concrete (Concreto Reforçado com Fibras de Aço).

Steel Fiber-reinforced Self-compacting Concrete (Concreto Autoadensável Reforçado com Fibras de Aço).

Slurry Infiltrated Fiber Concrete.

Slurry Infiltrated Mat Concrete.

Synthetic fiber Fiber-Reinforced Concrete (Concreto Reforçado com Fibras Sintéticas). 
UHPC

Ultra High Performance Concrete (Concreto de Ultraalto Desempenho).

Palavras em língua estrangeira

Dog bone shaped Faz referência à forma dos corpos de prova utilizados nos ensaios de tração direta.

Strain gages

Traduz-se por extensômetros elétricos.

Twisted

Traduz-se como torcida. Faz referência à forma de uma das três fibras utilizadas neste estudo.

Termos e definições

Razão de aspecto Definida como a razão entre o comprimento e o diâmetro equivalente das fibras.

Strain-hardening Diz respeito ao comportamento pós-fissuração de compósitos que apresentam cargas residuais maiores do que aquela observada à primeira fissura.

Strain-softening Diz respeito ao comportamento pós-fissuração de compósitos que apresentam cargas residuais inferiores àquela observada à primeira fissura. 


\section{1 \\ Introdução}

O concreto de cimento Portland se consolidou como o material de construção mais utilizado no mundo durante o século vinte. Neste período foram executadas barragens, pontes, usinas nucleares, túneis, portos, aeroportos, dentre inúmeras outras obras de infraestrutura no Brasil que impulsionaram o desenvolvimento técnico-econômico e a indústria do concreto no contexto nacional. Acompanhando este desenvolvimento, foi elaborada uma extensa normalização que incluía os requisitos que se aplicavam aos insumos e ao próprio concreto de cimento Portland. Outro passo na direção da qualidade dos processos relacionados com o concreto foi a recente elaboração da norma NBR 15146-1 [2], que regulamenta e estabelece a qualificação necessária ao pessoal que lida com a avaliação de qualidade do produto.

As construções em concreto tradicionais demandam grande dispêndio de trabalho devido à sua natureza artesanal, incluindo processos como execução de fôrmas, escoramento, armação, preparação do concreto, lançamento, cura, desenforma, acabamento, entre outros. Objetivando-se aumentar da eficiência na execução de obras foi necessário melhorar a produtividade com emprego de novos sistemas construtivos, conjugando-os com novas tecnologias em concreto. A partir da evolução da tecnologia do concreto e do aperfeiçoamento dos métodos construtivos, as possibilidades foram multiplicadas, resultando no desenvolvimento do concreto bombeável, pré-moldado, autoadensável e fibroso.

No meio acadêmico, a utilização de matrizes cimentícias reforçadas com fibras vem sendo estudada intensamente a partir da década de sessenta, a fim de superar a natureza frágil do concreto e de trazer novas possibilidades para utilização como material de construção. A combinação do concreto fibroso com o concreto armado e protendido, ao mesmo passo que tem potencialidade para substituir parcela das armaduras convencionais, pode conferir ao concreto características especiais. 
As fibras oferecidas no mercado possuem uma gama enorme de formas e são fabricadas a partir de materiais distintos. Algumas fibras podem ser usadas também na forma de tecidos, porém por razões econômicas, a utilização de fibras aleatoriamente dispersas em matrizes cimentícias sempre se manteve em evidência. As fibras mais utilizadas como reforço secundário no concreto armado são as fibras de polipropileno e as fibras de aço, ambas com a função de controlar a abertura e propagação de fissuras. A primeira é comumente utilizada para combater os efeitos da retração nas primeiras idades do concreto e a segunda para combater as fissuras de médio e longo prazo, ocasionadas por efeito de cargas cíclicas e impacto. Ambas as utilizações incrementam a vida útil e a segurança das estruturas, trazendo consigo benefícios de ordem econômica pela menor intervenção, manutenção e reparos.

O mecanismo por trás da incorporação de fibras no concreto está na habilidade das mesmas criarem pontes entre fissuras e controlarem a sua propagação e abertura, incrementando por consequência a tenacidade, as tensões residuais de tração e a rigidez à flexão. Do ponto de vista estrutural, a adição de fibras em volume considerável pode resultar no aumento da capacidade resistente e ductilidade do elemento estrutural, extrapolando os limites de carga convencionais para manter as mesmas condições de serviço.

As normas para cálculo de estruturas de concreto armado ainda são omissas quanto à consideração da influência da adição de fibras e não relacionam muito bem como se desenvolve a mecânica da abertura de fissuras. Outra dificuldade enfrentada para dimensionamento de estruturas com concreto reforçado com fibras é que os métodos normalizados para caracterização dos materiais não levam em conta a tenacidade dos mesmos, trazendo a necessidade de se estudar inicialmente o efeito escala nos ensaios. A partir daí, tem sido realizado um grande esforço no meio acadêmico para analisar o comportamento mecânico dos materiais compósitos, culminando na proposição de novos ensaios para melhor caracterizá-los e no desenvolvimento de modelos que orientam seu dimensionamento para finalidade estrutural. 


\section{1 Motivação e objetivos}

A motivação para realização deste trabalho surgiu da oportunidade de se analisar o comportamento mecânico um concreto que reunia as potencialidades do concreto reforçado com fibras de aço e do concreto autoadensável. Para caracterização destas misturas sob tração direta, se fez necessário a proposição de uma metodologia experimental, pois não havia normalização para realização deste ensaio. Também foi motivação contribuir com resultados de tração direta e de flexão em painéis circulares, pois se carece de publicações por razão de dificuldades associadas à realização destes ensaios. Outra motivação foi a possibilidade de se investigar o comportamento à flexão de vigas armadas concretadas com os mesmos concretos caracterizados.

O objetivo deste trabalho é analisar o comportamento mecânico de concretos autoadensáveis reforçados com três tipos distintos de fibras de aço, em frações volumétricas crescentes.

No estado fresco, os concretos foram caracterizados por meio do ensaio de abatimento modificado utilizando como referência a norma ASTM C1611 [3]. No estado endurecido, os concretos foram caracterizados por meio de ensaios de determinação da resistência à compressão e do módulo elástico utilizando como referência as normas ASTM C39 [4] e ASTM C469 [5]; de determinação da resistência à tração na flexão (ASTM C1609 [6]); e de determinação tração direta por meio de método experimental. Em ambos os casos foram contabilizadas as energias de deformação.

No nível semiestrutural, foram realizados ensaios de flexão em painéis circulares de concreto utilizando como referência a norma ASTM C1550 [1]. Para todos os ensaios, foram contabilizadas as energias de deformação, observandose a relação de carga para abertura de fissuras e o modo de ruptura das amostras.

No nível estrutural foram realizados ensaios experimentais de flexão em vigas armadas, cuja influência da incorporação de fibras de aço no concreto armado foi analisada por meio da observação dos momentos correspondentes à 
aberturas de fissuras de magnitudes arbitradas. Em todos os ensaios investigaram-se as deformações nas barras de aço e concreto por meio de extensômetros elétricos, sendo as deformações dos concretos também avaliadas por meio de sistema de correlação digital de imagens. Os deslocamentos centrais, por sua vez, foram monitorados diretamente por meio de transdutor de deslocamento e, indiretamente por meio de sistema de correlação digital de imagens.

\section{2}

\section{Estrutura do trabalho}

Este trabalho foi dividido nos sete capítulos descritos abaixo:

Capítulo 1 - Introdução: A introdução aborda os desafios contemporâneos que motivaram o estudo e descreve brevemente o programa experimental realizado.

Capítulo 2 - Revisão da literatura: Este capítulo aborda o panorama histórico da utilização dos concretos reforçados com fibras e descreve suas propriedades e características.

Capítulo 3 - Programa experimental: O terceiro capítulo agrupa os dados sobre as características dos insumos utilizados, descreve o programa de ensaios utilizados neste trabalho e as metodologias adotadas para realização dos ensaios.

Capítulo 4 - Resultados e análises: Neste caítulo, os dados de ensaios são analizados e discutidos.

Capítulo 5 - Conclusões: Este capítulo compreende todas as conclusões obtidas a partir da análise de todo o programa experimental.

Capítulo 6 - Referências bibliográficas: Este capítulo contém uma lista de todas as fontes de pesquisa utilizadas. 


\section{2 Revisão da literatura}

\section{1}

\section{Perspectiva histórica sobre a tecnologia do concreto}

O concreto e o aço são os materiais mais utilizados em aplicações estruturais. O aço é produzido sob condições controladas, cujas propriedades são avaliadas por meio de ensaios mecânicos, antes de sua utilização. O concreto, por sua vez, possui variabilidade intrínseca, que se deve às incertezas relacionadas com os seus materiais constituintes e ao processo de fabricação. $O$ controle de qualidade do cimento é garantido pelos fabricantes de maneira similar ao do aço, porém a qualidade do produto "concreto" depende dos lotes dos insumos, do controle de qualidade estabelecido, da precisão de dosagem na usina, do método de mistura, dos fatores ambientais, dos processos executivos e, também, dos procedimentos e métodos utilizados na avaliação de suas características. A variabilidade na produção causada por fatores humanos podem ser superadas com o controle adequado dos processos e a qualificação de pessoal. Segundo Neville [7], ambos os fatores devem ser levados em consideração pelos projetistas, pois há uma grande probabilidade dos concretos produzidos possuírem propriedades diferentes daquelas consideradas nos cálculos estruturais. O concreto, entretanto, é um material compósito de simples fabricação, constituído de partículas de agregados dispersos em uma matriz cimentícia, formada comumente por cimento Portland, água, aditivos químicos e adições minerais.

Em meados da década de 1960, a indústria do concreto e os projetistas estruturais utilizavam amplamente concretos de resistências características à compressão de 15 a $20 \mathrm{MPa}$. Neste momento da história, os concretos simples eram bem conhecidos, confiáveis e economicamente viáveis. No início da década de 1970, um grupo de projetistas e fornecedores de concreto iniciaram o estudo e desenvolvimento de concretos com objetivo de dobrar sua resistência. Os concretos denominados como de alta resistência (40 a $60 \mathrm{MPa}$ ) foram utilizados em número significativo de estruturas na área de Chicago durante a 
década de 1970, multiplicando em até três vezes as resistências no período de dez anos [8]. Depois de alcançada a resistência de $60 \mathrm{MPa}$, houve uma barreira tecnológica que não pôde ser superada com as matérias-primas disponíveis no mercado, pois os aditivos redutores de água disponíveis na época não se mostraram capazes de reduzir ainda mais os teores água/cimento, porque quando superdosados, incorporavam ar e retardavam os tempos de pega das misturas. Foi então que, na década de 1980, os primeiros superplastificantes com grande capacidade de redução de água surgiram no mercado. A partir da utilização destes redutores mais eficientes, os pesquisados conseguiram estudar concretos com teores a/c abaixo de 0,30 concluindo, entretanto, que este teor de água não era suficiente para hidratar completamente o cimento [9]. Contudo, Godfrey apud Aïtcin [9] reduziu o teor a/c abaixo de 0,30 utilizando cimento e superplastificantes cuidadosamente selecionados, obtendo a resistência de $130 \mathrm{MPa}$. Banche apud Aïtcin [9], utilizou teores a/c abaixo de 0,16 por meio da alta dosagem de superplastificante e substituição parcial de cimento por uma adição ultrafina, a microssílica, alcançando resistências à compressão da ordem de $280 \mathrm{MPa}$. A partir do início da década de 1990, a resistência do concreto foi elevada a outros patamares, mas esta já não era a única capacidade almejada, porque the foram atribuídas outras características especiais como: durabilidade, sustentabilidade, resistência aos ambientes agressivos, dentre outras. A partir de então, a utilização dos concretos de alto desempenho foi crescendo em vários países, mas representando ainda um pequeno volume do concreto fornecido no mercado. Em contrapartida, diversos países iniciaram seus maiores programas de estudo sobre concreto de alto desempenho, com conseguente aumento em número de publicações, revistas, seminários e congressos. Segundo Aïtcin [9], as tecnologias e os avanços são resultado dos programas de pesquisa iniciados nos Estados Unidos da América, Noruega, Canadá, França, Suíça, Austrália, Alemanha, Japão, Coreia, China e Taiwan.

Os termos relacionados com o concreto foram publicados no ACI Committee 116R [10] (Cement and Concrete Terminology), no ASTM C125 [11] (Standard Terminology Relating to Concrete and Concrete Aggregates) e, mais recentemente, no $\mathrm{ACl} \mathrm{CT}-16$ [12] ( $\mathrm{ACl}$ Concrete Terminology). desenvolvimento da tecnologia do concreto foi se aperfeiçoando e caminhou na direção do desenvolvimento de novas tecnologias como o HSC, LWAC, SCC, FRC/FRCC, HPFRCC e ECC. Outras nomenclaturas que foram revisadas por Naaman [13]. Segundo Zollo [14], houve um acordo quanto à terminologia do 
concreto reforçado com fibras a partir do ACI 544.1R [15], cujos termos adotados para os concretos reforçados com fibras passaram a ser definidos pelo tipo de fibra: SFRC para os concretos reforçados com fibras de aço, GFRC para os concretos reforçados com fibras de vidro, SNFRC para os concretos reforçados com fibras de carbono e polipropileno e, NFRC para os concretos reforçados com fibras de origem natural.

\section{2}

\section{Concretos reforçados com fibras de aço}

Segundo Bentur [16], data da antiguidade a utilização de fibras para melhorar o comportamento mecânico dos materiais. Incorporava-se palha e crinas de cavalo procurando aumentar a ductilidade de materiais frágeis utilizados no revestimento de casas e na fabricação de tijolos. Mehta \& Monteiro [17] citam que, há evidências de que as fibras de amianto foram utilizadas para o reforço de potes de argila há mais de 5000 anos atrás. Segundo a norma ACI 544.1R [15], desde a invenção do processo por Hatschek em 1898, ocorreu uso comercial em grande escala de matrizes de pasta cimentícia com fibras de amianto, mas por razão dos riscos associados à saúde atribuídos à indústria do amianto, novas fibras começaram a ser utilizadas em substituição entre as décadas de 1960 e 1970.

Os concretos reforçados com fibras de aço são materiais compostos por uma matriz cimentícia e fibras aço aleatoriamente dispersas. Esta matriz pode ser representada por um concreto, uma argamassa ou uma pasta, contendo também materiais pozolânicos, aditivos químicos e fibras de um ou mais tipos. Depois de anos de estudos experimentais em concretos reforçados com fibras de aço (SFRC) e em concretos de alto desempenho reforçados com fibras de aço (HPSFRC), foi possível alcançar incrementos significativos na resistência e tenacidade das misturas. Estes novos materiais ofereceram possibilidades interessantes para projeto e recuperação de estruturas, pois materiais cimentícios em geral são caracterizados pela baixa resistência à tração e pela pequena capacidade de deformação, pois são materiais rígidos. Esta fragilidade foi superada historicamente com a utilização de barras de aço contínuas para suportar as forças de tração e cisalhamento impostas às estruturas. Bentur \& Mindess [16] afirmam que, enquanto as armaduras convencionais promovem o aumento da capacidade de carga das estruturas, as fibras, por 
outro lado, podem ser utilizadas como reforço descontínuo na matriz cimentícia, controlando a abertura e propagação de fissuras.

Dependendo do volume de fibras incorporado ao concreto, pode ocorrer aumento substancial das resistências de tração e flexão pós-fissuração. Este efeito decorre por efeito das pontes formadas pelas fibras entre fissuras, impedindo sua propagação e abertura. Este pressuposto leva à conclusão de que existem aplicações em que o reforço fibroso pode ser mais eficiente do que a armação convencional $[17,16]$.

Em baixas frações volumétricas, (menores que 1\%) as fibras oferecem vantagens sobre a tela soldada, pois reduzem a fissuração de retração induzida pelas variações de umidade e temperatura de pavimentos, distribuindo de maneira mais eficiente as cargas por causa da sua distribuição aleatória no concreto. As fibras de aço também são menos sujeitas à corrosão do que as armaduras longitudinais e reduzem diretamente os custos da mão-de-obra envolvidos na execução das armações. Neste caso elas agem como reforço secundário, promovendo alguma ductilidade pós-fissuração.

Com frações moderadas de fibras (entre 1 e 2\%) há incremento do módulo de ruptura, da tenacidade à fratura e da resistência ao impacto. Esta fração volumétrica é utilizada em componentes que precisam resistir localmente a cargas de grande magnitude e deformações consideráveis, requerendo capacidade de absorção de energia, como no caso do concreto projetado em linhas de túneis, estruturas resistentes a explosões e estruturas pré-moldadas.

Com altas frações de fibras (maiores que $2 \%$ ), os concretos são denominados de concretos de alto desempenho reforçados com fibras de aço (HPSFRC). Por causa do seu aparente enrijecimento à flexão, eles podem ser utilizados como reforço principal em elementos esbeltos ou, em conjunto com as armaduras convencionais, promovendo ao mesmo tempo maior resistência e tenacidade.

\section{3}

\section{Tipos de fibras de aço}

As fibras de aço utilizadas como reforço nos SFRCs são definidas na $\mathrm{ACI} 544.1 \mathrm{R}$ [15] como curtas, formadas por pequenos comprimentos de aço, 
tendo razão de aspecto entre 20 e 100, com uma ou várias seções diferentes ao longo do seu comprimento e, que são suficientemente pequenas para serem dispersas em uma mistura de concreto fresco utilizando métodos de mistura tradicionais. A razão de aspecto é a relação entre o comprimento e o diâmetro equivalente das fibras $\left(\ell_{f} / d_{e}\right)$. Quando a fibra possui seção regular, o diâmetro equivalente pode ser calculado por meio da eq. (2.1), do contrário, se utiliza a relação de massa e densidade (vide eq. (2.2)).

$$
\begin{gathered}
d_{e}=\sqrt{\frac{4 \cdot A}{\pi}}, \operatorname{com} A=w \cdot t \\
\operatorname{com} A=\frac{m}{\rho \cdot \ell_{f}}, d_{e}=\sqrt{\frac{4 \cdot m}{\pi \cdot \rho \cdot \ell_{f}}}
\end{gathered}
$$

Onde,

$d_{e} \quad$ diâmetro equivalente da fibra;

$A$ = área da seção da fibra;

$w \quad=$ largura da fibra;

$t \quad=$ espessura da fibra;

$\ell \quad=$ comprimento da fibra;

$\rho \quad=$ densidade do aço;

$m \quad$ = massa da fibra.

As fibras de aço são classificadas pela ASTM A820 [18] conforme sua origem e tipo: I) estiramento a frio; II) chapas de corte; III) fundição; IV) usinagem e; V) estiramento a frio modificado [15, 18]. Segundo a ACI 544.3R [19], as fibras de aço disponíveis no mercado possuem comprimentos entre 6,4 a $63,5 \mathrm{~mm}$, diâmetros entre 0,45 a $1,00 \mathrm{~mm}$ e são utilizadas comumente nas frações volumétricas de 0,25 a $2,00 \%$ (i.e. de $20 \mathrm{~kg} / \mathrm{m}^{3}$ a $157 \mathrm{~kg} / \mathrm{m}^{3}$ ). A norma EN 14889 [20] estabelece que fibras devem possuir resistência à tração média maior ou igual a $345 \mathrm{MPa}$ e densidade média de $7850 \mathrm{~kg} / \mathrm{m}^{3}$, quando fabricadas a partir de aço comum e, de $7950 \mathrm{~kg} / \mathrm{m}^{3}$, quando fabricadas em aço inoxidável [20]. Tipicamente são encontradas no mercado fibras retas, curvas, torcidas e amorfas, com superfícies lisas ou estampadas. Paralelamente ao desenvolvimento das diversas geometrias (vide Figura 1), busca-se melhorar a ancoragem das fibras por meio da modificação de suas pontas com dobra ou 
achatamento. Atualmente, fibras de aço com geometrias mais complexas e tratamentos superficiais estão sendo desenvolvidos, buscando-se melhorar cada vez mais a aderência fibra-matriz.

Os tratamentos superficiais empregados nas fibras objetivam melhorar tanto a resistência à corrosão quanto a microestrutura desenvolvida no entorno das fibras. Porém a norma EN 206 [21] ressalta que o desempenho dos concretos que contém estas fibras precisa ser investigado antes da sua utilização, pois foi reportado reatividade em casos particulares.

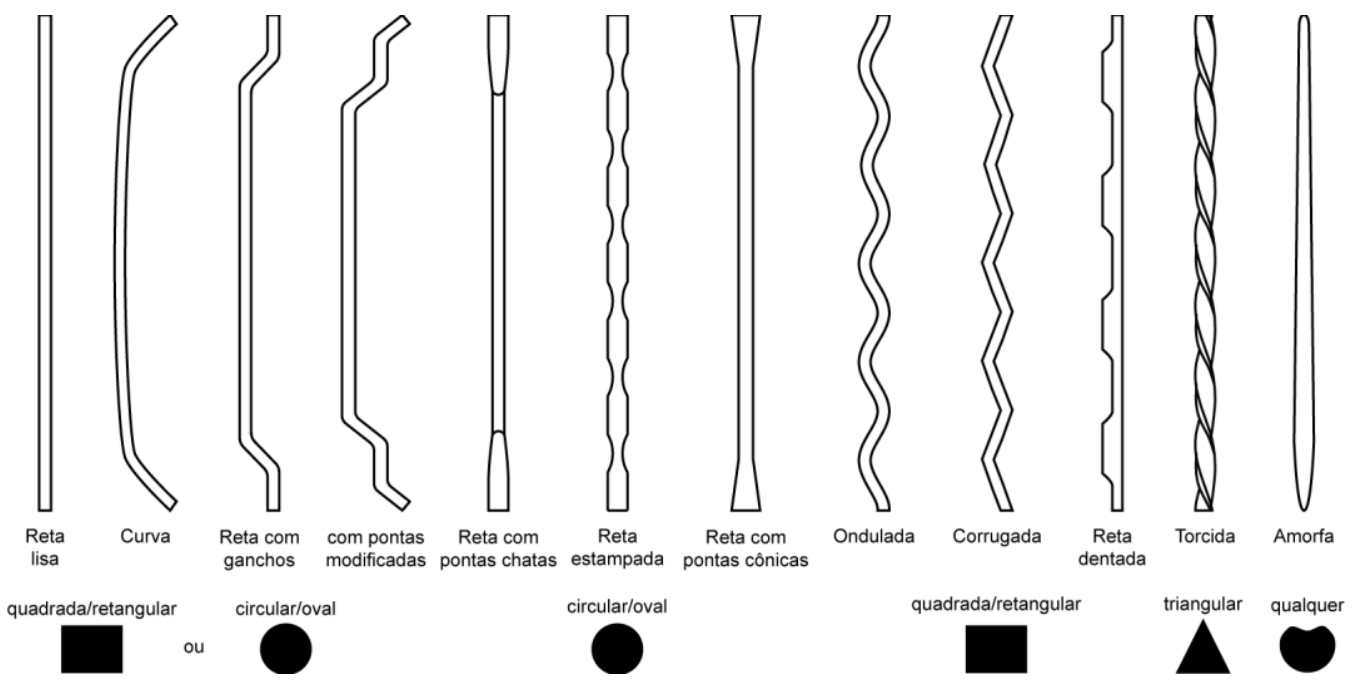

Figura 1 - Tipos de fibras de aço e seções transversais típicas.

\section{4}

Propriedades dos concretos reforçados com fibras de aço

\subsection{1}

Propriedades dos SFRSCCs no estado fresco

O recente avanço na tecnologia do concreto se deve, em grande parte, pelo desenvolvimento dos aditivos superplastificantes e das adições suplementares ao cimento. Estes materiais possibilitaram reduzir gradualmente os teores a/c e contribuíram para a melhoria da reologia dos concretos. Uma das propostas consistiu em substituir parcela do cimento utilizado por produtos naturais ou resíduos industriais, conhecidos como pozolanas. São exemplos de pozolanas as cinzas vulcânicas, as pedras vulcânicas moídas, as cinzas volantes geradas pela indústria energética e a escória de alto forno industrial. Também se incluem nesta lista novos materiais cimentícios como a microssílica resultante da produção de silício e de ferro-silício, os fillers calcários resultantes 
do processo de produção do clínquer, as cinzas da casca de arroz trituradas e o diatomito. Algumas adições como as cinzas volantes e as cinzas da casca de arroz possuem propriedades aglomerantes e têm potencial para utilização mesmo como simples adição, pois sua propriedade pozolânica permite a reação lenta com o cimento a partir da hidratação do silicato dicálcico e silicato tricálcico, formando silicato de cálcio hidratado. Segundo Aïtcin [22], estas adições contribuem para reduzir a perda de abatimento, normalmente prejudicada pelos altos consumos de cimento. Ainda segundo Aïtcin [22], as adições além de contribuírem para evitar a segregação causada pela superdosagem de aditivos redutores de água e promovem maior viscosidade às misturas no estado fresco, resultando em melhor manutenção e trabalhabilidade quando comparados aos concretos simples. A alta fluidez com ausência de segregação sempre foi almejada pela indústria para aumentar a eficiência na construção civil, que fomentou o desenvolvimento dos concretos autoadensáveis. Buscava-se obter concretos com habilidade de ser bombeado de forma rápida, preenchendo as fôrmas e os espaços deixados entre as armaduras e blocos de rochas, sem a necessidade de compactação durante o processo de lançamento. Houve a partir daí o desenvolvimento e proposição de métodos de dosagem de misturas autoadensáveis, buscando a viabilidade econômica e o desempenho em termos de resistência, tenacidade, permeabilidade, abrasão, ausência de fissuração e de retração plástica. Por estes e outros motivos técnico-econômicos, não se abriu mão de se utilizar agregados nas composições de misturas autoadensáveis, sendo desenvolvidas técnicas para compor um esqueleto granular compacto envolto por uma pasta cimentícia, relacionando-se as frações materiais com as características desejadas nos estados fresco e endurecido [23, 24], incluindo ou não a influência das fibras de aço $[25,26]$.

O comportamento do concreto no estado fresco é comumente resumido em termos da trabalhabilidade, que representa a habilidade dos concretos de serem misturados, manipulados, transportados e, o mais importante, serem lançados e adensados com a menor perda de homogeneidade, mínima incorporação de ar e mínima exsudação. Estas habilidades dependem da composição do concreto, dos equipamentos utilizados na mistura e transporte, da exposição ambiental, do tempo decorrido desde o início da mistura, das condições das fôrmas e, principalmente, do método de lançamento e adensamento. Sabe-se que os concretos reforçados com fibras de aço 
respondem mecanicamente com certa anisotropia, pois não ocorre uma distribuição perfeita e uniforme de fibras na matriz. Este aspecto mostrou-se sensível ao método de mistura, lançamento e vibração, que devem ser convenientemente planejados para não induzir aglomeração e o alinhamento das fibras. Observou-se que as fibras também mostram um alinhamento preferencial paralelo à direção do lançamento e às paredes das fôrmas (efeito de parede). Este efeito pode ser ampliado quando se trata de elementos com uma dimensão predominante, resultando em distribuições de fibras muito diferentes para uma viga e uma laje, comparativamente [27, 28, 29]. No caso dos concretos autoadensáveis, alguns autores [30,31] tem discutido a influência da direção do lançamento e do fluxo do concreto na orientação das fibras. Esses diversos fatores de influência na orientação e distribuição das fibras indicam a dificuldade de se parametrizar as características dos concretos para compreensão dos fenômenos que governam a mecânica do fluxo e consolidação do concreto, porque ao contrário dos líquidos comuns, o concreto é composto por diversas partículas, de diferentes dimensões (de poucos nanômetros a alguns centímetros) e de vários tipos (orgânicos ou minerais), suspensos na água.

O estudo da interação entre as partículas do concreto é realizado com interface entre várias disciplinas. Os conhecimentos em física e química são utilizados para se correlacionar as proporções constituintes dos materiais com as propriedades macroscópicas da mistura no estado fresco e, o conhecimento em mecânica dos fluidos permite a análise dos ensaios que definem estas propriedades. Estes ensaios consistem em submeter os corpos de prova à condições de carregamento mais ou menos controladas, a exemplo dos ensaios de abatimento, espalhamento, caixa $L$, funil $\mathrm{V}$, anel $\mathrm{J}$, dentre vários outros [32]. Ferraris [33] afirma, que esta abordagem de engenharia buscou, em um primeiro momento, quantificar e qualificar os concretos quanto a sua habilidade de ser lançado de forma mais simples, rápida e barata possível. Depois do desenvolvimento de inúmeros ensaios para avaliar o comportamento das misturas cimentícias, buscou-se modelar seu fluxo. Segundo de Larrard \& Hu [34], este processo iniciou-se pela determinação de parâmetros globais utilizados na dinâmica das misturas viscoelásticas com auxílio de reômetros, que foram posteriormente relacionados com a dosagem e com os índices de ensaio. Segundo Ferraris \& de Larrard [35], há relação direta destes parâmetros com o abatimento e tempos de escoamento. A utilização de reômetros, entretanto, não foi considerada rápida e prática para ser adotada no canteiro de obras, onde os 
ensaios de abatimento e espalhamento ainda são os mais utilizados para se avaliar a trabalhabilidade dos concretos. Pelo fato do concreto fluir na escala de observação, o comportamento do concreto pôde ser relacionado com os modelos de Bingham (eq. (2.3)) e Hershel and Bulkley (eq. (2.4)). Segundo Roussel [36], estes modelos relacionam a tensão cisalhante com a taxa de cisalhamento por meio da viscosidade e da tensão de escoamento. Ainda segundo Roussel [36], a tensão de escoamento pode ser associada à capacidade de preenchimento ou, de forma mais geral, se o concreto irá fluir ou não quando Ihe é aplicada uma tensão. A viscosidade plástica, por sua vez, pode ser associada à velocidade que é dada ao concreto quando o fluxo é iniciado, pois é a razão de proporcionalidade entre a força horizontal e o gradiente de velocidades. No caso dos concretos autoadensáveis, o fluxo se inicia devido ao efeito do peso próprio, que induz o gradiente de pressões. Quando a superfície do autoadensável não está nivelada, este gradiente gera uma tensão cisalhante no concreto, que por sua vez gera uma taxa de cisalhamento, que motiva o fluxo até o nivelamento da camada superior, cessando a pressão que o originou. Ferraris [33] afirma, que o concreto também pode ser tratado como uma suspensão de partículas, pois ele é composto de agregados suspensos em um meio viscoso de pasta cimentícia, na qual a pasta, por si só, pode ser considerada heterogênea e constituída de partículas de grãos de cimento em um meio líquido representado pela água (e aditivos). Nestes modelos relaciona-se a viscosidade, a concentração de suspensão e o empacotamento. Quando são incluídas fibras, os modelos de empacotamento são estendidos, considerando-se uma perturbação ou um diâmetro de empacotamento equivalente [25, 37].

$$
\begin{gathered}
\left\{\begin{array}{l}
\dot{\gamma}=0 \rightarrow \tau<\tau_{0} \\
\dot{\gamma} \neq 0 \rightarrow \tau=\tau_{0}+f(\dot{\gamma})
\end{array}, \text { sendo } f(\dot{\gamma})=\eta \dot{\gamma}\right. \\
\left\{\begin{array}{l}
\dot{\gamma}=0 \rightarrow \tau<\tau_{0} \\
\dot{\gamma} \neq 0 \rightarrow \tau=\tau_{0}+f(\dot{\gamma})
\end{array}, \text { sendo } f(\dot{\gamma})=K \dot{\gamma}^{n}\right.
\end{gathered}
$$

Onde,

$\tau, \tau_{0}=$ tensão cisalhante, tensão de escoamento, respectivamente;

$\eta \quad=$ viscosidade plástica;

$\dot{\gamma}=$ taxa de cisalhamento;

$K, n=$ constantes. 
O estudo do comportamento dos materiais cimentícios no estado fresco tem ganhado espaço nos últimos anos, com crescente número de publicações no campo da simulação numérica. Diferentes abordagens vêm sendo consideradas como a fluidodinâmica computacional de materiais homogêneos e a modelagem de fluidos viscosos com elementos distintos discretos, considerando-se a interação e o movimento entre partículas individuais. Nesta abordagem, a viabilidade para aplicações em escala real no campo prático limita-se pela capacidade computacional para lidar com as condições complexas do reforço estrutural. Superadas estas limitações do campo computacional, será viável responder perguntas sobre o comportamento local do fluxo de partículas em regiões densamente armadas, prevendo a aglomeração de fibras de aço sobre as condições de lançamento impostas e contribuindo de forma significativa na resolução de problemas de engenharia. Há também um esforço atual do meio acadêmico para se entender melhor a relação das pressões desenvolvidas nas fôrmas com os aspectos materiais, para o aperfeiçoamento dos processos de controle de qualidade [36, 38, 39].

\subsection{2 \\ Propriedades dos SFRSCCs no estado endurecido}

A norma $\mathrm{ACl}$ 544.4R [40] aponta que os fatores de maior influência nas propriedades mecânicas dos concretos autoadensáveis reforçados com fibras de aço são: o tipo da fibra; a relação comprimento/diâmetro (razão de aspecto); a quantidade de fibras; a resistência da matriz; o tamanho, forma e método de preparação do corpo de prova e; o diâmetro do agregado. A adição de fibras aço influencia também nos modos de falha dos compósitos por razão do mecanismo de transferência de tensões promovido pelo efeito conjunto do cisalhamento interfacial e intertravamento fibra-matriz. Além da própria matriz, as variáveis mais importantes que governam as propriedades dos concretos reforçados com fibras de aço são a quantidade (i.e. percentagem de fibras em massa ou volume com relação ao metro cúbico de concreto adensado) e a eficiência do reforço fibroso. A eficiência do reforço fibroso pode ser avaliada pela resistência de uma única fibra ao arrancamento, que depende da força de adesão com a interface fibra-matriz. Para fibras retas e lisas, as resistências ao arrancamento serão tão maiores quanto forem suas razões de aspecto e, quanto mais longas forem, mais eficiente será o incremento nas capacidades mecânicas do compósito. 
A resistência ao arrancamento é proporcional à área superficial da interface fibra-matriz, cujas fibras irregulares com seções de pequeno diâmetro promovem maior resistência ao arrancamento que fibras circulares de grande diâmetro. Utiliza-se a razão comprimento/diâmetro (razão de aspecto) para representar a maior eficiência do reforço fibroso em termos gerais. Infelizmente, como reportado na $\mathrm{ACI}$ 544.4R [40], do ponto de vista prático o uso de fibras com razão de aspecto maior do que 100 implica comumente em uma pior trabalhabilidade ou, em uma distribuição não uniforme das fibras, podendo ocorrer ambos, quando as misturas são realizadas por meio de métodos de mistura tradicionais. Em todo caso, o aumento da resistência ao arrancamento pode ser alcançado alternativamente com a utilização de fibras que possuem superfícies deformadas ou dispositivos de ancoragem (vide Figura 2). Ainda segundo a ACI 544.4R [40], na maioria das aplicações práticas são empregadas fibras de razão de aspecto menor que 100, cuja falha do compósito ocorre antes das fibras serem arrancadas. A norma ACI 544.4R [40] ressalva ainda, que o modo de falha com arrancamento de fibras tem a vantagem de ser gradual e dúctil se comparada à falha rápida e catastrófica quando ocorre ruptura das fibras por tração; e geralmente quanto mais dúcteis forem as fibras, mais dúcteis e graduais serão os processos da fissuração do concreto.

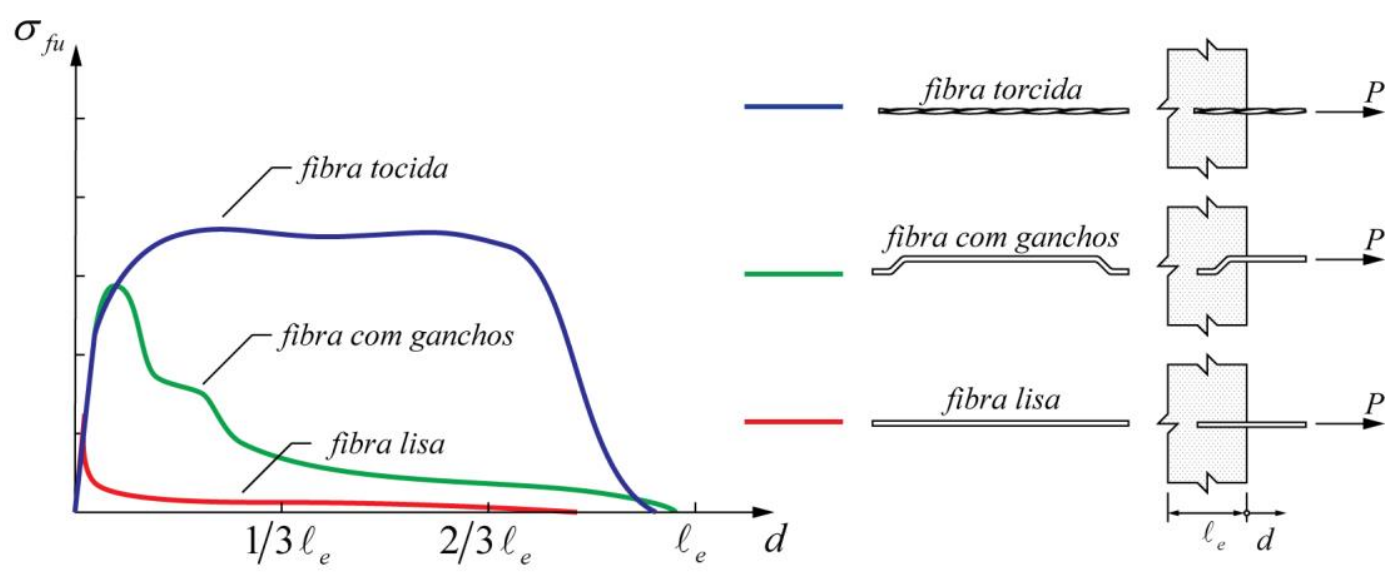

Figura 2 - Comportamento geral ao arrancamento de fibras torcidas, com ganhos e lisas; adaptado de [41]. 


\subsection{3 \\ Mecanismos de pré e pós-fissuração}

Os fatores relacionados com as fibras que representam maior influência no estado endurecido dos SFRCs são, segundo Brandt [42]: a resistência à tração, o módulo elástico, a razão de aspecto, a quantidade, a orientação, a distribuição, e adesão com a matriz cimentícia. Os mecanismos físico-químicos de adesão com a matriz são comumente avaliados por meio de ensaios de arrancamento de fibras e pela caracterização interfacial. Já a distribuição e orientação das fibras por sua vez são avaliadas qualitativa ou quantitativamente por meio de análise de imagens de raios- $x$ ou tomografia computadorizada. Este último método, entretanto, possui limitações quanto ao tamanho das amostras e comumente se limita a estudos de laboratório; dificuldade que vem sendo transposta com o desenvolvimento de novos métodos não destrutivos [31, 43].

A avaliação da influência da orientação e distribuição de fibras, bem como a análise de outros fatores como a razão de aspecto e quantidade podem ser feitas através de ensaios de caracterização. Entretanto, Bentur \& Mindess [16] ressaltam que a observância da influência da distribuição e orientação das fibras no comportamento mecânico do concreto sugere, que para análise ou controle de qualidade, talvez seja mais adequado cortar ou extrair amostras a partir de grandes elementos. Os demais fatores que influenciam no comportamento mecânico dos SFRCs se devem às características da matriz como resistência e diâmetro máximo dos agregados; às características dos corpos de prova como dimensão, geometria, método de moldagem e; aos métodos de ensaio como, por exemplo, a taxa de carregamento. Para que seja aumentado o grau de confiabilidade na utilização dos SFRCs, necessita-se ainda, que as incertezas relacionadas com a orientação e distribuição das fibras sejam elucidadas. $O$ reconhecimento da relevância desses aspectos nas propriedades dos SFRCs levanta a necessidade de se introduzem parâmetros que considerem estas variabilidades, bem como a necessidade de se avaliar a distribuição de fibras das estruturas no estado. Para se avaliar os efeitos da orientação e distribuição de fibras, pode-se levar em conta a abordagem teórica desenvolvida por Kaw [44], que assume algumas hipóteses da resistência dos materiais e faz simplificações a fim de transformar o comportamento de um material heterogêneo real, em um material elástico e homogêneo: 
a) a adesão é perfeita entre as fibras e a matriz;

b) o módulo elástico, os diâmetros e os espaços entre as fibras são uniformes;

c) as fibras são contínuas e paralelas;

d) as fibras e a matriz seguem a lei de Hooke (elásticos lineares);

e) as fibras possuem resistência uniforme;

f) o compósito não possui vazios.

A abordagem de Kaw [44] utiliza uma lâmina composta pela fibra e matriz, formando um compósito de mesma altura e profundidade, onde cada um dos componentes assume sua própria espessura e altura comum (vide eq. (2.5-2.7)). Neste caso, as frações das áreas de fibras e matriz são proporcionais aos seus volumes, definindo as relações de frações volumétricas (eq. (2.8) e eq. (2.9)). Quando esta amostra hipotética lamelar sofre ação de uma carga de tração, esta força pode ser considerada proporcionalmente distribuída entre a matriz e fibras, sendo posteriormente escritas em termos de tensões (vide equação 2.10). Assumindo que o compósito resultante seja isotrópico e obedece à lei de Hooke, no limite de proporcionalidade, as deformações de ambos os materiais serão iguais (vide eq. (2.11) e eq. (2.12)). Por fim, se forem utilizadas as definições de fração volumétrica, a eq. (2.8) resulta na regra das misturas (eq. (2.13)). Dela, parte o princípio de combinar dois materiais distintos para incrementar capacidades ao compósito resultante como, por exemplo, melhorar a estabilidade térmica, aumentar a resistência, tenacidade, dentre outros aspectos afins.

$$
\begin{gathered}
A_{c}=t_{c} \cdot h \\
A_{m}=t_{m} \cdot h \\
A_{f}=t_{f} \cdot h \\
V_{f}=\frac{A_{f}}{A_{c}}=\frac{t_{f}}{t_{c}} \\
V_{m}=\frac{A_{m}}{A_{c}}=\frac{t_{m}}{t_{c}}=1-V_{f} \\
\sigma_{c} \cdot A_{c}=\sigma_{m} \cdot A_{m}+\sigma_{f} \cdot A_{f} \\
E_{c} \cdot \varepsilon_{c} \cdot A_{c}=E_{m} \cdot \varepsilon_{m} \cdot A_{m}+E_{f} \cdot \varepsilon_{f} \cdot A_{f}
\end{gathered}
$$




$$
\begin{gathered}
E_{c}=E_{m} \cdot \frac{A_{m}}{A_{c}}+E_{f} \cdot \frac{A_{f}}{A_{c}} \\
E_{c}=E_{m} \cdot V_{m}+E_{f} \cdot V_{f}
\end{gathered}
$$

Onde,

$$
\begin{aligned}
& A_{c}, A_{m}, A_{f}=\text { área do compósito, matriz e fibras, respectivamente; } \\
& t_{c}, t_{m}, t_{f} \quad=\text { espessura do compósito matriz e fibras, respectivamente; } \\
& h \quad=\text { = altura da lâmina de referência (compósito); } \\
& V_{c}, V_{m}, V_{f}=\text { volume do compósito, matriz e fibras, respectivamente; } \\
& \sigma_{c}, \sigma_{m}, \sigma_{f}=\text { tensão no compósito, matriz e fibras, respectivamente; } \\
& \varepsilon_{c}, \varepsilon_{m}, \varepsilon_{f}=\text { deformação no compósito, matriz e fibras, respectivamente; } \\
& E_{c}, E_{m}, E_{f}=\text { módulo elástico do compósito, matriz e fibras, respectivamente. }
\end{aligned}
$$

A regra das misturas introduzida na eq. (2.13) deriva-se de diversas hipóteses e simplificações e não leva em conta outros aspectos importantes do comportamento dos SFRCs como a força de aderência fibra-matriz, a distribuição descontínua das fibras e as resistências residuais na zona de pósfissuração. Alguns autores [16, 31], entretanto, sugerem a introdução de dois fatores de eficiência $\left(\eta_{\ell}\right.$ e $\left.\eta_{\theta}\right)$. O fator $\eta_{\ell}$ diz respeito à eficiência que uma fibra pode ter em função da direção do carregamento, no qual cada fibra pode exercer a função de simples inclusão, quando a mesma está sobre um plano ortogonal ao do carregamento $\left(\eta_{\ell}=0\right)$, até sua eficiência máxima $\left(\eta_{\ell}=1\right)$, quando ela está alinhada na direção do carregamento. Já o fator $\eta_{\theta}$ se relaciona com os efeitos provocados pela distribuição irregular das fibras de aço na matriz cimentícia, que são idealizados para os arranjos 1D, 2D e 3D (vide Figura 3a e Figura 3b). Aveston \& Kelly [45] sugeriram relacionar o fator de eficiência $\eta_{\theta}$ com o número de fibras por unidade de área com a utilização de curvas de densidade de probabilidade (vide eqs. (2.14 e 2.15$)$ ). 
Arranjo espacial das fibras em uma, duas e três dimensões:
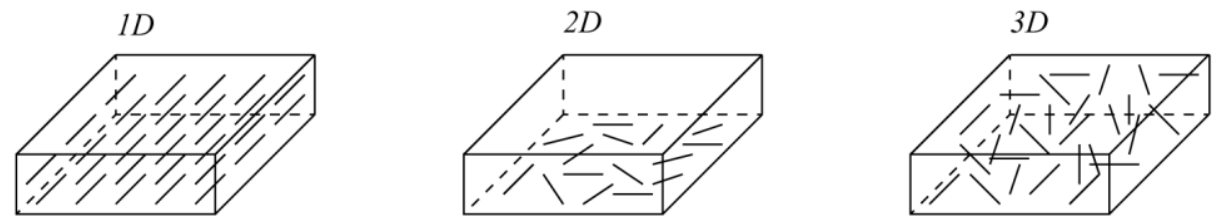

Modelo equivalente:
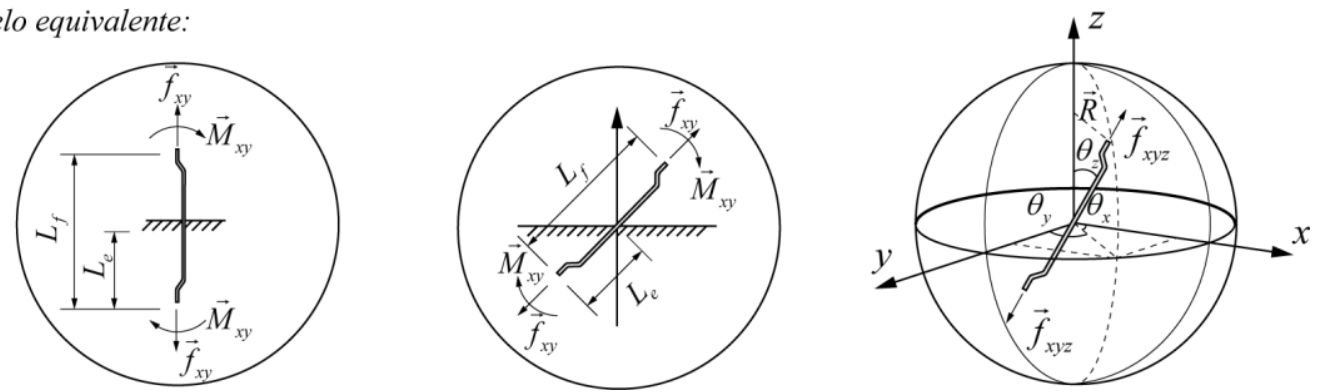

Figura 3 - Arranjos espaciais de fibras idealizados

para o arranjo 2D: $\quad \eta_{\theta}=\int_{0}^{\pi / 2} n \cdot \frac{2}{\pi} \cdot \sin \theta \cdot d \theta=\frac{2 n}{\pi}$

para o arranjo 3D: $\quad \eta_{\theta}=\int_{0}^{\pi / 2} n \cdot \cos \theta \cdot \sin \theta \cdot d \theta=\frac{n}{2}$

$$
n=\frac{V_{f}}{A_{f}}=\frac{4 \cdot V_{f}}{\pi \cdot d_{f}^{2}}
$$

Onde,

$n \quad$ = número de fibras alinhadas na seção transversal;

$V_{f} \quad$ fração volumétrica de fibras;

$A_{f} \quad=$ área de fibras;

$d_{f} \quad$ diâmetro das fibras.

O coeficiente de eficiência $\eta_{\ell}$ busca traduzir os efeitos intrínsecos da interação fibra-matriz, que é influenciada pelas propriedades geométricas das fibras, pela rugosidade superficieal e qualidade da interface fibra-matriz. Estes efeitos são analisados conjuntamente em termos dos mecanismos de transferência das tensões entre a fibra e a matriz, relacionando a tensão média ao longo da fibra com sua resistência à tração, sendo dada por $\eta_{\ell}=\bar{\sigma}_{f} / \sigma_{f u}$. Kelly apud Brandt [42] introduziu o conceito de comprimento crítico $\ell_{c r}$, definido como comprimento necessário para que as fibras sejam arrancadas da matriz ou exibam falha por tração. Segundo Bentur \& Mindess [16], este comprimento 
crítico pode ser estimado por meio do equilíbrio da força interfacial de cisalhamento com a de tração na fibra, partindo da hipótese que a fissura passa na metade do seu comprimento (equação 2.17). Ainda segundo Bentur \& Mindess [16], quando o comprimento da fibra é menor que o comprimento crítico, existe uma parcela insuficiente do seu comprimento ancorado para que seja gerada uma tensão igual à sua resistência última à tração, antes de ser arrancada. Em contrapartida, quando este comprimento excede um comprimento crítico, haverá parte suficiente da fibra ancorada para que ela seja solicitada à sua tensão de escoamento.

Bentur \& Mindess [16] afirmam que, nos compósitos formados a partir de matrizes frágeis, pode-se considerar que a capacidade resistente da matriz se esgota após o limite de proporcionalidade (i.e. $\varepsilon_{m u}=\varepsilon_{m}=\varepsilon_{f}$ ); e quando o volume de fibras excede um volume chamado crítico $\left(V_{f(c r i t)}\right)$, a tensão resistente do compósito será suportada apenas pelas fibras, tracionadas na sua tensão máxima $\sigma_{f u}$. Ao se desprezar a parcela resistente da matriz na regra das misturas (vide eq. (2.17) e eq.(2.19)), a tensão no compósito no estágio de pósfissuração $\sigma_{c u}$ será dado pela eq. (2.20). Quando o volume de fibras é inferior ao volume crítico, a capacidade de carga das fibras expressa pela resistência $\sigma_{c u}$, é menor que a resistência da matriz à primeira fissura $\sigma_{m u}$. Arbitrando os coeficientes de eficiência iguais à unidade, a interseção das equações $2.19 \mathrm{e}$ 2.20 resulta no volume crítico de fibras (vide eq. (2.21)).

Ao se considerar valores típicos dos materiais utilizados em aplicações dos SFRCs $\left(V_{f}\right.$ de $2 \%, E_{f}$ de $210 \mathrm{GPa}$ e, $E_{m}$ de $30 \mathrm{GPa}$ ), observa-se que 0 aumento do módulo elástico será menor que $10 \%$. Ou seja, em termos práticos $E_{c}$ não é muito maior que $E_{m}$ e, a eq. (2.21) resulta na eq. (2.22)). Muito embora Bentur \& Mindess [16] ressaltam que, neste caso, os coeficientes de eficiência serão diferentes daqueles considerados para a zona de pré-fissuração.

$$
\begin{gathered}
E_{c}=E_{m} \cdot\left(1-V_{f}\right)+\eta_{\ell} \cdot \eta_{\theta} \cdot E_{f} \cdot V_{f} \\
\sigma_{m u}=\sigma_{m u}^{\prime} \cdot\left(1-V_{f}\right)+\eta_{\ell} \cdot \eta_{\theta} \cdot \frac{\sigma_{m u}^{\prime}}{E_{m}} \cdot E_{f} \cdot V_{f}
\end{gathered}
$$




$$
\begin{gathered}
\frac{\sigma_{m u}}{\sigma_{m u}^{\prime}}=\left(1-V_{f}\right)+\eta_{\ell} \cdot \eta_{\theta} \cdot \frac{E_{f}}{E_{m}} \cdot V_{f}=\frac{E_{c}}{E_{m}} \\
\sigma_{c u}=\eta_{\ell} \cdot \eta_{\theta} \cdot \sigma_{f u} \cdot V_{f} \\
V_{f(c r i t)}=\frac{E_{c}}{E_{m}} \cdot \frac{\sigma_{m u}^{\prime}}{\sigma_{f u}} \\
V_{f(c r i t)}=\frac{\sigma_{m u}^{\prime}}{\sigma_{f u}} .
\end{gathered}
$$

Onde,

$$
\begin{aligned}
& E_{c} \quad \text { = módulo elástico do compósito; } \\
& E_{m} \quad \text { = módulo elástico da matriz; } \\
& E_{f} \quad \text { = módulo elástico das fibras; } \\
& \eta_{\ell} \quad=\text { fator de eficiência relacionado com o comprimento crítico da fibra; } \\
& \eta_{\theta}=\text { fator de eficiência relacionado com o ângulo relativo da fibra com a } \\
& \sigma_{m u}=\text { tensão no compósito na iminência de ruptura; } \\
& \sigma_{m u}^{\prime}=\text { tensão de ruptura da matriz. } \\
& \sigma_{c u} \quad=\text { tensão no compósito após a primeira fissura; } \\
& \sigma_{f u}=\text { tensão de escoamento das fibras de aço; } \\
& V_{f} \quad \text { fração volumétrica de fibras (como igual à área média de fibras na }
\end{aligned}
$$

Bentur \& Mindess [16] afirmam que é possível aumentar a resistência mecânica do compósito depois da ocorrência da primeira fissura na matriz, quando o volume de fibras empregado excede o volume crítico. Este volume calculado por meio da eq. (2.21) se encontra no intervalo de 0,2 a $15 \%$, considerando matrizes cimentícias de 30 a $90 \mathrm{MPa}$ e fibras de aço com tensões admissíveis entre 600 a $2100 \mathrm{MPa}$. Entretanto, a eq. (2.21) foi desenvolvida considerando fibras contínuas e alinhadas, dentre outras simplificações 
supracitadas como, por exemplo, a perfeita adesão fibra-matriz. Por outro lado, se forem levados em contra os fatores de eficiência, os volumes críticos serão ainda maiores. Segundo Bentur \& Mindess [16], espera-se que o aumento dos volumes críticos devidos aos fatores $\eta_{\ell}$ e $\eta_{\theta}$ sejam da ordem de 3 a 6 vezes, para distribuições aleatórias em duas e três dimensões. Nos casos práticos, observa-se ainda, que a quantidade máxima de fibras que é convenientemente misturada por meio dos processos de mistura convencionais se encontra no intervalo de 1 a $3 \%$. Além disto, Li et al. [46] ressalvam que a adição de fibras pode resultar no aumento da porosidade e de ligações frágeis na matriz. Por estes motivos, Bentur \& Mindess [16] afirmam que, para a maioria dos concretos produzidos in situ, a presença de fibras resulta na melhoria da ductilidade pósfissuração, mas não contribui efetivamente no aumento da capacidade de carga pós-fissuração, sendo observando o comportamento tensão-deformação conhecido como strain-softening. Por este motivo, ainda há o interesse no desenvolvimento de novos meios de controlar a reologia dos concretos, no aperfeiçoamento nos métodos de mistura e dosagem, no uso de novas fibras e, na melhoria das propriedades interfaciais, buscando-se obter o comportamento de strain-hardening (i.e. capacidade de carga na zona de pós-fissuração maior do que aquela observada na primeira fissura) com pequenas frações volumétricas de fibras.

Quando as fibras possuem comprimento menor que o comprimento crítico (i.e. $\ell \ll \ell_{c r}$ ), a ruptura do compósito na zona pós-fissuração ocorre predominantemente pelo arrancamento de fibras. Quando $\ell \gg \ell_{c r}$ em contrapartida, a ruptura se dá por escoamento das fibras na tensão $\sigma_{f u}$ (vide Figura 4). Este comprimento crítico pode ser determinado ao se considerar que a fissura passa a meio comprimento da fibra e que há equilíbrio entre as tensões de cisalhamento e de tração (vide eq. (2.23)). Partindo destas premissas, o fator de eficiência $\eta_{\ell}$ definido na eq. (2.24) pode ser reescrito para $\ell \leq \ell_{c r}$ e $\ell \geq \ell_{c r}$ utilizando-se distribuições de tensões hipotéticas triangulares ou trapezoidais (eq. 2.25). 

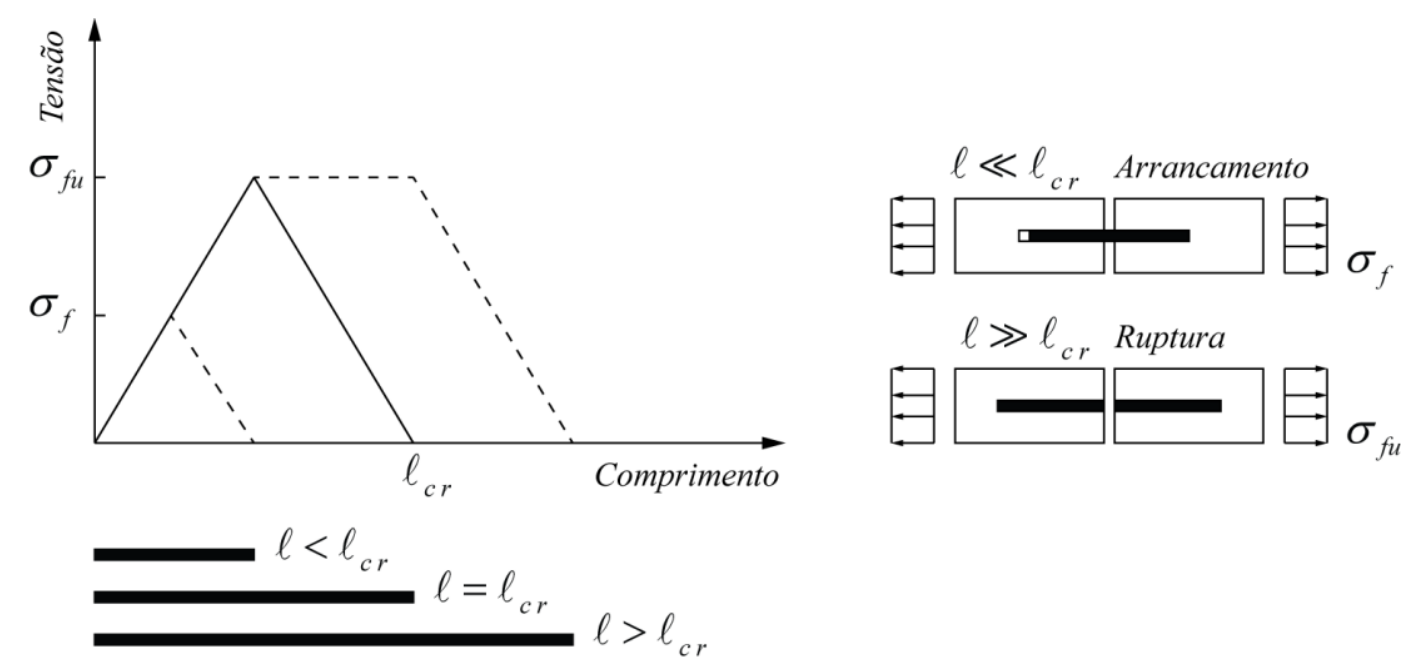

Figura 4 - Modelo para distribuição das tensões em função do comprimento crítico de fibras retas e lisas; adaptado de Brandt [42]

$$
\begin{gathered}
1 / 2 \cdot \ell_{c r} \cdot \pi \cdot d_{f} \cdot \tau_{f u}=1 / 4 \cdot \pi \cdot d_{f}^{2} \cdot \sigma_{f u} \\
\ell_{c r}=1 / 2 . d \cdot \frac{\sigma_{f u}}{\tau_{f u}}=r \cdot \frac{\sigma_{f u}}{\tau_{f u}} \\
\eta_{\ell}=\bar{\sigma}_{f} / \sigma_{f u} \\
\left\{\begin{array}{l}
\text { para } \ell_{f} \leq \ell_{c r} \rightarrow \eta_{\ell}=\frac{\tau_{f u}}{2 r \cdot \sigma_{f u}}=\frac{\ell_{f}}{2 \ell_{c r}} \\
\text { para } \ell_{f} \geq \ell_{c r} \rightarrow \eta_{\ell}=1-\frac{\ell_{c r}}{2 \ell_{f}}
\end{array}\right.
\end{gathered}
$$

Onde,

$\ell_{c r} \quad=$ comprimento crítico das fibras;

$d_{f} \quad$ diâmetro das fibras;

$\tau_{f u}=$ tensão de adesão fibra-matriz;

$\sigma_{f u}=$ tensão de escoamento da fibra de aço;

$\eta_{\ell} \quad=$ fator de eficiência relacionado com o comprimento crítico da fibra;

$\ell_{f} \quad=$ comprimento das fibras;

$\bar{\sigma}_{f}=$ tensão média das enésimas fibras de aço. 
Segundo Brandt [42], as equações supracitadas se mostram inadequadas para matrizes frágeis, pois a adesão com as fibras não é perfeita e a fissuração da matriz modifica consideravelmente este fenômeno, tornando-se inválida para todos os intervalos de carregamentos dos concretos reforçados com fibras. Porém, autores propuseram modificações da eq. (2.25) para a zona de pré e pós-fissuração, como Krenchel, Riley, Allen e Laws apud Brandt [42]. Neste contexto, os estudos apontam para dois objetivos centrais: o estudo da relação das propriedades da fibra com a natureza da adesão com a matriz e a modelagem da interação fibra-matriz, buscando dar subsídio à predição do comportamento e resistência ao arrancamento de uma única fibra.

\subsection{4}

\section{Zona de transição interfacial}

Os materiais cimentícios reforçados com fibras de aço são compósitos formados essencialmente por duas fases distintas - a primeira é representada pela matriz cimentícia, que pode ser pasta, argamassa ou concreto e, a segunda se caracteriza pelas fibras. A região compreendida entre estas duas fases, conhecida como Zona de Transição Interfacial (Interfacial Transition Zone, ou ITZ), possui microestrutura consideravelmente diferente do restante da matriz. Segundo Maso [47], a ITZ se estende aproximadamente $50 \mu \mathrm{m}$ da superfície das fibras e sua natureza depende tanto das propriedades das fases vizinhas, quanto das condições dependentes do tempo, a exemplo da mistura, hidratação, cura e envelhecimento dos materiais [16, 42]. Segundo Brandt [42], a razão principal da formação da ITZ entre dois componentes adjacentes é que as partículas de agregados são diferentemente empacotadas contra a superfície impenetrável das fibras de aço (wall effect). Outro efeito negativo relatado por Maso apud Brandt [42] é que, depois da adição de água à mistura, todas as partículas secas são cobertas por uma lâmina de água e de uma rede de cristais finos de etringita.

A ITZ é composta por algumas camadas distintas: a camada de hidróxido de cálcio ( $\mathrm{CH}$ layer), que pode ser uma camada fina de $1 \mu \mathrm{m}$ (duplex film) até uma camada muito mais densa com alguns micrômetros; e uma camada porosa que é resultante dos vazios formados entre o silicato hidratado de cálcio (C-S-H) e a etringita (vide Figura 5). Bentur \& Mindess [16] ressaltam que esta camada de hidróxido de cálcio adjacente à superfície da fibra não é necessariamente 
contínua e contem áreas altamente porosas formadas por alguns cristais de C-S-H e etringitas. Também ressaltam que, na vizinhança da zona porosa pode ser encontrada uma camada fina de hidróxido de cálcio, como a duplex film, porém menos densa. Como resultado, a interface fibra-matriz pode não ser necessariamente o elo fraco mais fraco da ligação - mas sim a zona porosa que se estende de 10 a $40 \mu \mathrm{m}$ das camadas massivas de $\mathrm{CH}$ ( $\mathrm{CH}$ layer) até a matriz densa.

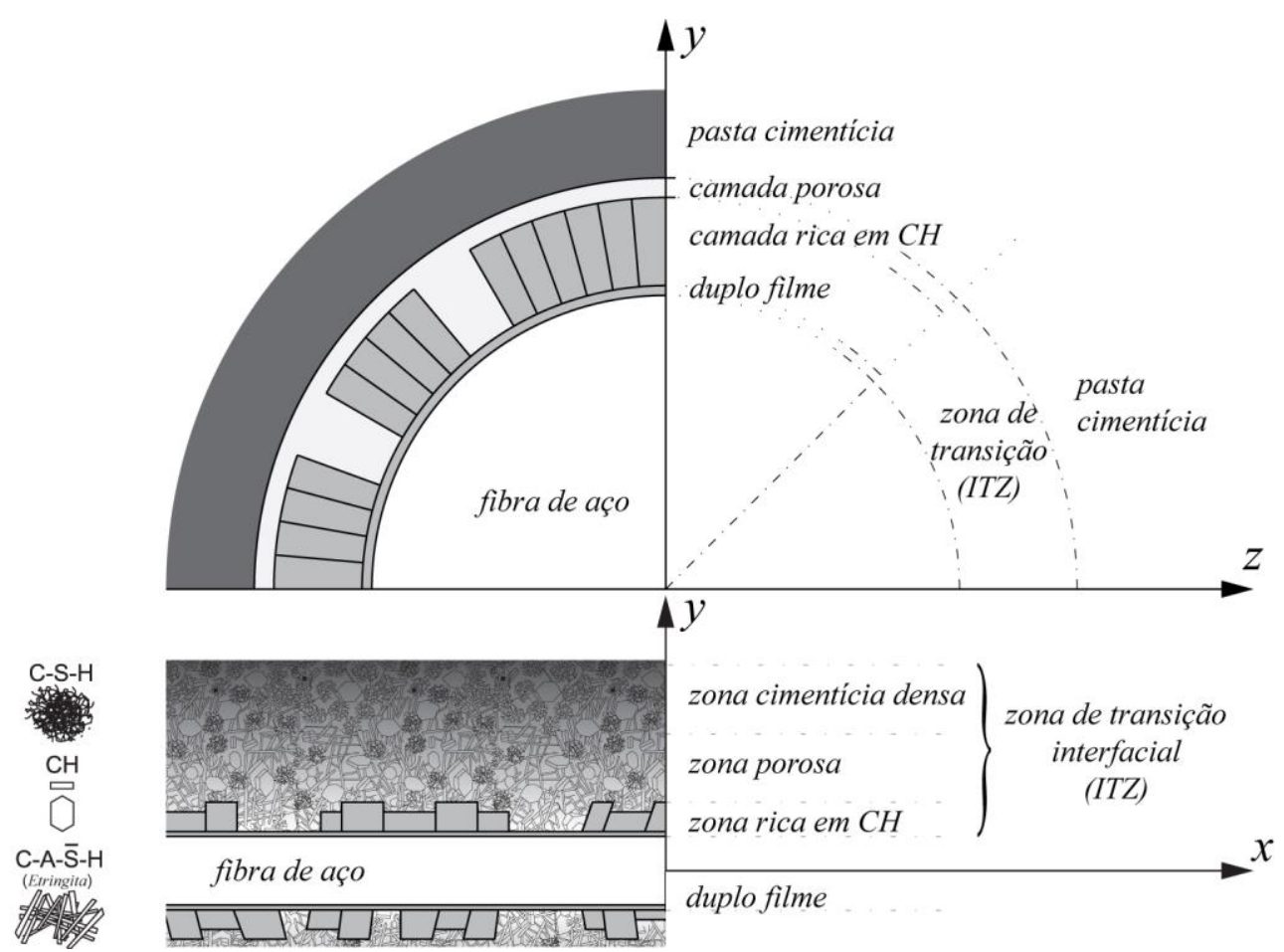

Figura 5 - Figura esquemática da microestrutura formada na vizinhança das fibras de aço; adaptado de [16, 47]

Foi reportado em [16, 42], que a qualidade da Zona de Transição Interfacial depende da matriz e dos processos de mistura. $O$ emprego de grande energia de mistura resulta em zonas de transição mais densas, trazendo como resultado melhor adesão fibra-matriz. Segundo Bentur \& Mindess [16], a zona de transição interfacial pode ser quase eliminada quando é feita dosagem de uma matriz bem graduada, contendo fillers, grãos finos de cimento e, quando são empregadas fibras de seções transversais suficientemente pequenas. Por razão das tensões serem transferidas de uma fase para outra nos materiais compósitos cimentícios, as características da interface fibra-matriz causam uma série de efeitos sobre a adesão e mecanismos de descolamento das fibras. Ocorre, que esta adesão entre as fibras e a matriz cimentícia é relativamente 
fraca, tendo contribuição significativa apenas nos compósitos que possuem grande área superficial de fibras [16, 42, 44].

\subsection{5}

\section{Mecanismos de transferência de tensões}

Os SFRCs comuns contêm fibras lisas com diâmetros da ordem de 0,1 mm, resultando em pequenas áreas superficiais de interação fibra-matriz que muitas vezes é insuficiente para promover reforço significante por adesão química. Isto acontece porque a ligação química da fibra com a matriz cimentícia tem natureza relativamente fraca, cujos processos de interação fibra-matriz ocorrem principalmente em um pequeno volume da matriz, no entorno das fibras, sendo a camada interfacial mais influenciada pelos efeitos de abrasão. Segundo Bentur \& Mindess [16], o reforço com fibras de aço só se tornou possível e eficiente com o desenvolvimento de dispositivos mecânicos de ancoragem promovidos por peculiaridades na geometria, a exemplo de indentações, ganchos e deformações. Entretanto, segundo Brandt [42], para fins de análise, as interações fibra-matriz são avaliadas de forma mais adequada quando se considera fibras curtas de aço, pois se excluem os fenômenos particulares causados pela baixa afinidade química, pela forma complexa e pela diferença de módulo elástico.

O primeiro modelo utilizado para descrever a transferência de tensões na fase elástica credita-se a Cox apud Bentur \& Mindess [16], que é conhecido como shear lag theory. Ela se baseia na análise do campo de tensões no entorno de uma fibra de geometria simples envolta por uma matriz elástica (vide Figura 6, eq. (2.26) e eq. (2.27)). 
a)

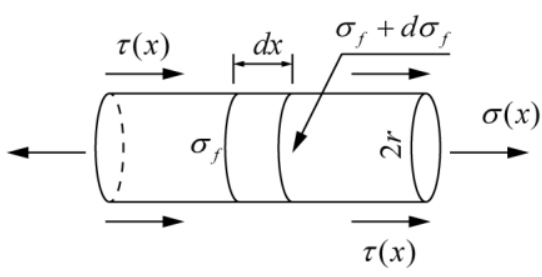

c)

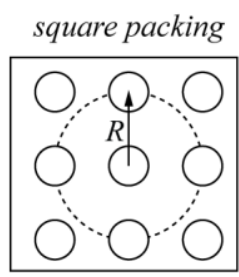

b)

antes do carregamento

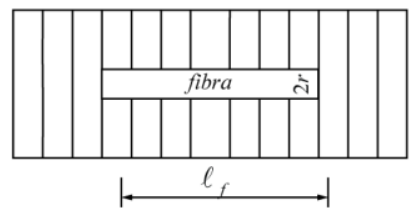

depois do carregamento

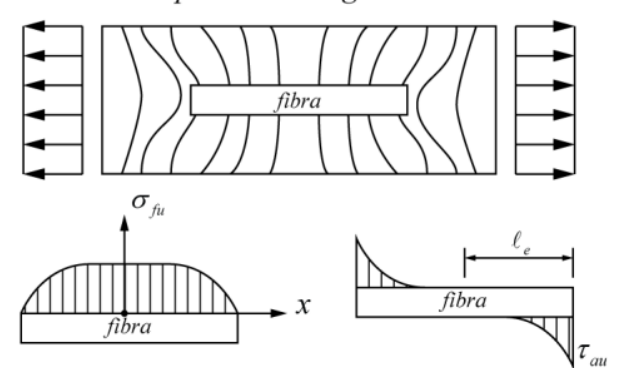

Figura 6 - llustração: a) da fibra de geometria simples utilizada nos modelos; b) da distribuição de tensões nas fibras de aço assumida para uma matriz perfeitamente elástica; c) dos arranjos espaciais quadrados e hexagonais; adaptado de $[49,16]$

$$
\begin{gathered}
\sigma_{f}=E_{f} \cdot \varepsilon_{c} \cdot\left[1-\frac{\cosh (n \cdot x / r)}{\cosh (n \cdot s)}\right] \\
\tau_{e}=\frac{1}{2} \cdot n \cdot E_{f} \cdot \varepsilon_{c} \cdot\left[\frac{\sinh (n \cdot x / r)}{\cosh (n \cdot s)}\right] \\
n^{2}=E_{m} /\left[E_{f} \cdot\left(1+v_{m}\right) \cdot \ln \left(R_{m} / r_{f}\right)\right] ; \\
s=L / r .
\end{gathered}
$$

Para os arranjos de empacotamento quadrados e hexagonais, respectivamente:

$$
\begin{gathered}
\ln (R / r)=\ln \left(\pi / V_{f}\right) / 2 ; \\
\ln (R / r)=\ln \left(2 \pi / \sqrt{3} \cdot V_{f}\right) / 2 ;
\end{gathered}
$$

Onde,

$\sigma_{f} \quad$ = tensão de tração da fibra de aço;

$E_{f} \quad=$ módulo elástico da fibra de aço;

$\varepsilon_{c} \quad=$ deformação do compósito;

$n, s$ = parâmetros adimensionais;

$x=$ coordenada $\mathrm{x}$ a partir do centro da fibra;

$r \quad=$ raio da fibra;

$R \quad$ = distância entre fibras igualmente espaçadas na matriz;

$v_{m} \quad=$ coeficiente de Poisson da matriz. 
Em outros tratamentos, são feitas distinções entre os processos que antecedem e sucedem as fissuras na matriz, no qual ambos os mecanismos são tratados simultaneamente, tais como a transferência de tensões elástica, o descolamento e o escorregamento friccional. No caso da pós-fissuração, o modelo assemelha-se ao anteriormente proposto por Cox [48], com a diferença que a máxima tensão cisalhante interfacial ocorre na parte central da fibra [49, 50, 51] (vide Figura 7).

a)

tensão cisalhanete adesional

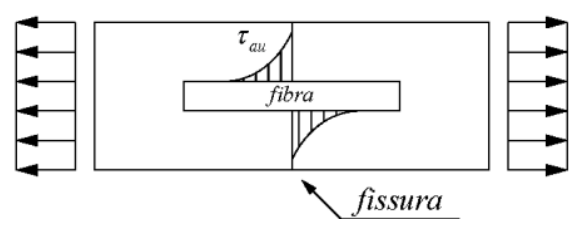

b) tensão cisalhanete adesional e friccional

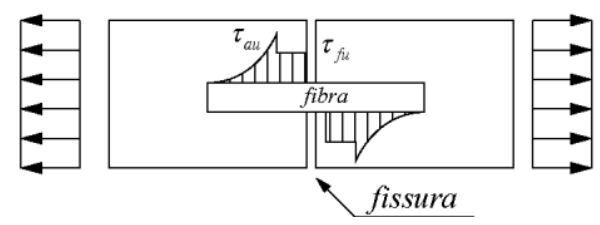

Figura 7 - Modelos da distribuição de tensões cisalhantes na fibra em compósito: a) íntegro; b) fissurado; adaptado de Bentur \& Mindess [16].

A capacidade de carga suportada pelas fibras é comumente avaliada por meio da determinação das características de uma única fibra ao arrancamento. Dois valores de força identificados nos gráficos carga-deslocamento se mostram suficientes para fins desta análise: a primeira se refere ao valor máximo correspondente ao fim da fase elástica e a segunda, à carga que corresponde à região de atrito, imediatamente após o descolamento. Estes valores de força são posteriormente escritos em função da tensão de cisalhamento adesional $\tau_{a u} \mathrm{e}$ da tensão máxima de cisalhamento friccional $\tau_{f u}$, cujas curvas dos ensaios de arrancamento mostram comportamentos entre os intervalos de slip-softening até slip-hardening (vide Figura 8b). 
a)
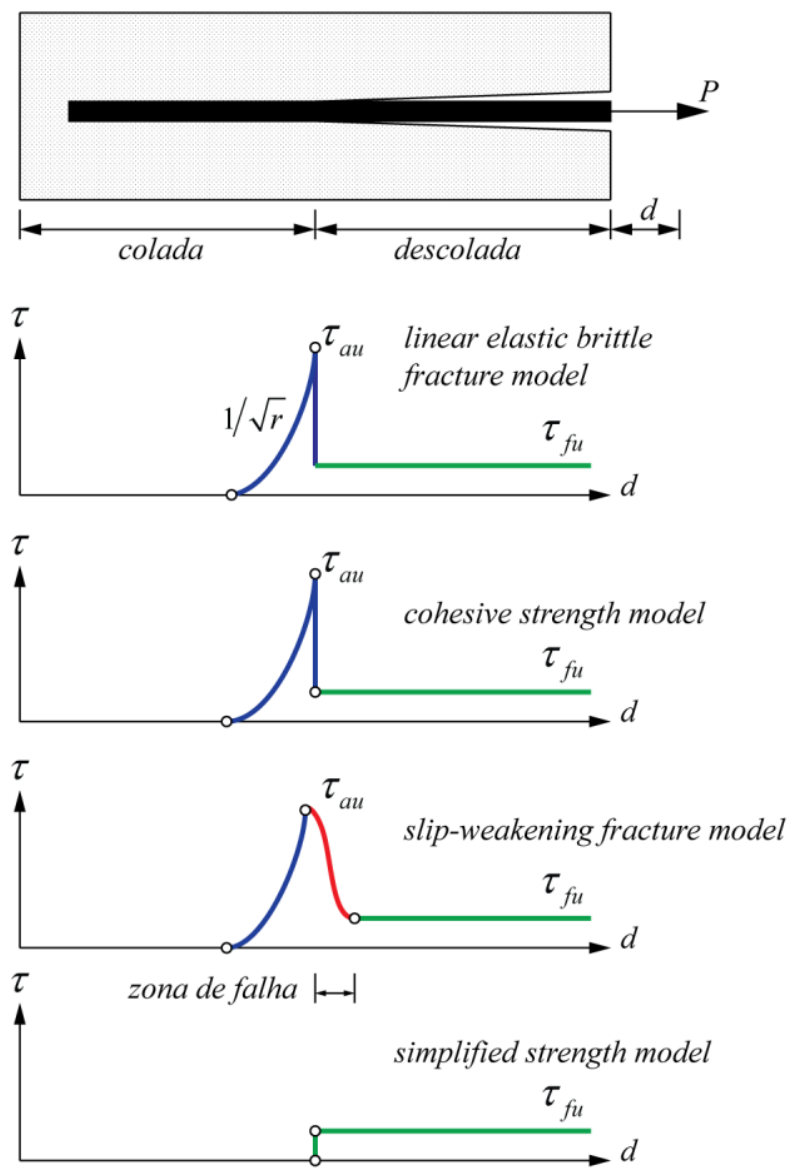

b)
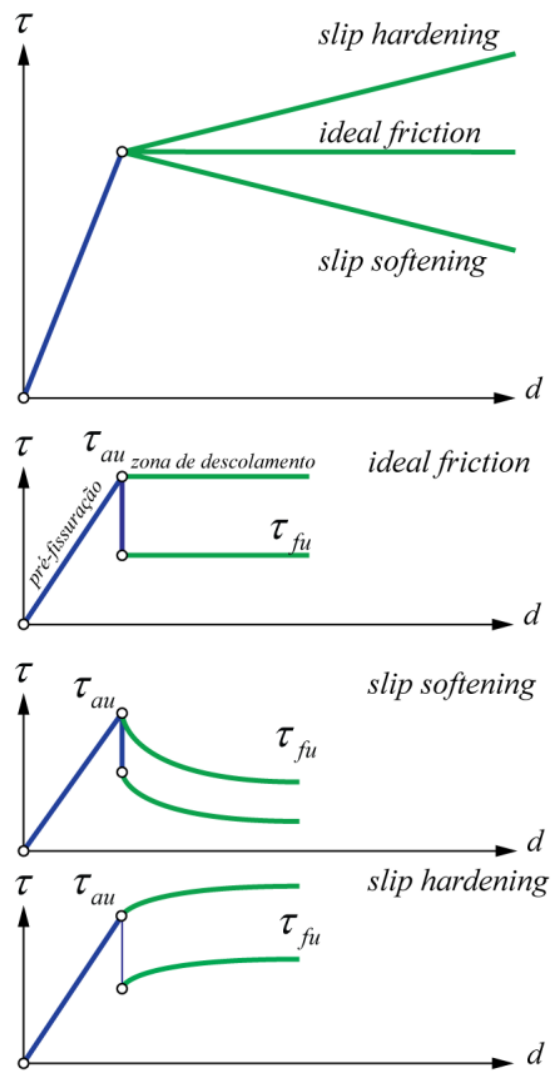

Figura 8 - Ilustração: a) dos modelos que descrevem as tensões cisalhantes ao longo das fibras; adaptado de Li \& Stang [51]; b) dos intervalos que descrevem as relações de tensões cisalhantes adesionais e friccionais; adaptado de Bentur \& Mindess [16].

Bentur \& Mindess [16] afirmam que antes do surgimento da primeira fissura, a transferência de tensões se dá pelo mecanismo predominante elástico, onde os deslocamentos longitudinais da fibra e da matriz são geometricamente compatíveis. A tensão desenvolvida na interface é a tensão cisalhante, que distribui a carga externa por meio da interface fibra-matriz. Ainda segundo Bentur \& Mindess [16], em estágios mais avançados de carga, o descolamento se inicia ao longo da interface, e o processo de transferência de tensões torna-se friccional. A tensão cisalhante friccional se caracteriza por um valor estático ou inicial de adesão ao qual precisa ser ultrapassado para que ocorra um deslocamento relativo na interface e, por um valor dinâmico de aderência necessário para manter o progresso do deslocamento a uma taxa correspondente. O processo de transição da fase elástica para a fase friccional se dá de forma gradual, no qual o módulo de $\tau_{f u}$ é muito sensível às tensões e 
deformações normais e, segundo Bentur \& Mindess [16], na maioria dos tratamentos analíticos, assume-se como sendo constante ao longo de todo processo de arrancamento (vide Figura 8a). Mehta \& Monteiro [17] afirmam, que depois que o descolamento se inicia, há uma combinação dos efeitos dos mecanismos de descolamento e do arrancamento friccional, que pode ser efeito da influência da geometria das fibras.

Os conceitos acerca da caracterização e da modelagem do comportamento ao arrancamento foram resumidos por Naaman et al. [50]. Estes modelos se basearam na análise das curvas de arrancamento de fibras retas, lisas e alinhadas, no qual se assumem tensões interfaciais adesionais elásticas, se tornando friccionais com o descolamento gradual ao longo da interface. Nos modelos posteriores, passou-se a calcular as contribuições das componentes de adesão elástica e friccional com relação à resistência e à energia global ao arrancamento, conforme demonstrado por Hansen apud Bentur [52] (vide Figura 9d). Uma curva típica de arrancamento de uma fibra curta pode ser vista na Figura 9c.

a)

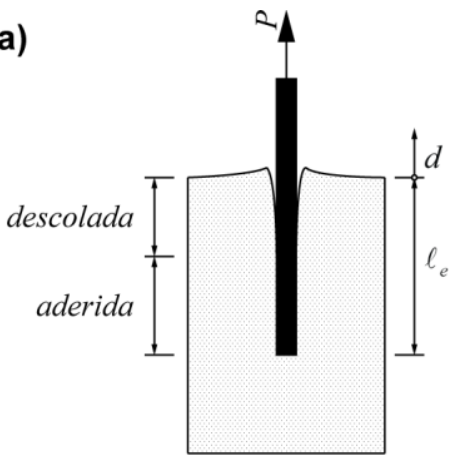

c)

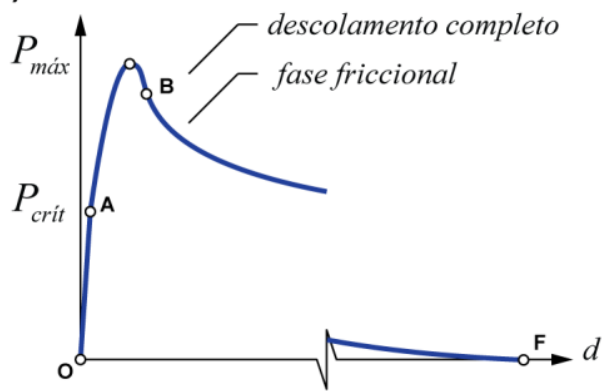

b)

d)
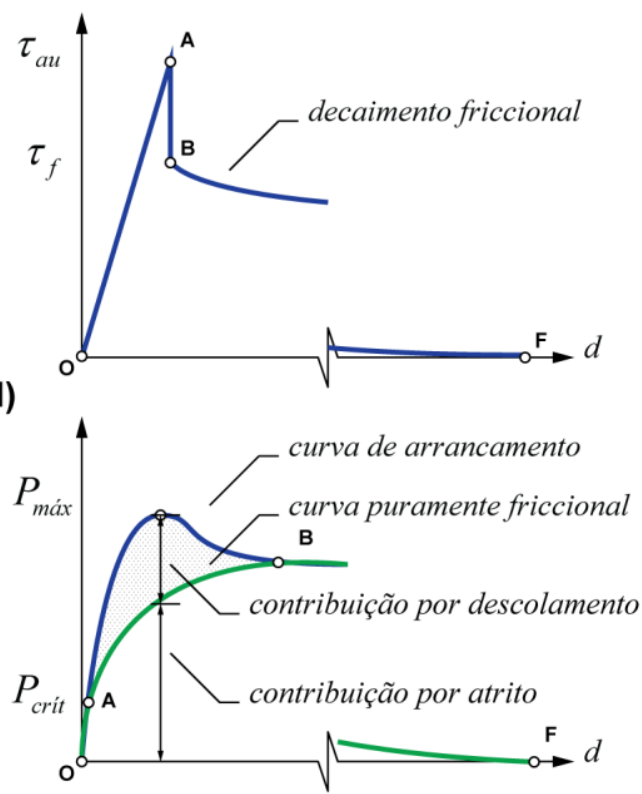

Figura 9 - llustração: a) do modelo de arrancamento com escorregamento de fibras lisas adaptado de Naaman et al. [50]; b) de um gráfico típico de tensão adesional versus deslocamento com decaimento friccional, adaptado de Naaman et al. [50]; c) de um gráfico típico de arrancamento versus deslizamento, adaptado de Alwan et al. [53]; d) da contribuição adesional e friccional da força total e da energia de arrancamento adaptado de Bentur et al. [52] 
Quando são utilizadas fibras com geometria modificada, as curvas de arrancamento mostram comportamento distinto (vide Figura 10). A parte ascendente da curva $(\mathrm{OA})$ se associa à transferência elástica ou adesional. No trecho seguinte da curva $(A B)$, o descolamento é iniciado e progride até que ocorra o descolamento completo (B). Em seguida, a fibra é arrancada oferecendo apenas a resistência ao atrito (BF). Nesta parte da curva, a carga de arrancamento é reduzida com o incremento do escorregamento, resultado da diminuição do comprimento ancorado da fibra e consequente decaimento da curva. Quando se trata de fibras com ganchos, a carga pode ser incrementada de $\mathrm{B}$ para $\mathrm{C}$ devido à ancoragem mecânica, começando a deslizar (CD), e a ser progressivamente deformada enquanto é arrancada da matriz (DE). Ao se utilizar fibras longas, o processo de deformação das pontas é gradual, ocorrendo em um ou mais estágios (D'-E'). Segundo Isla et al. [54], o processo de decaimento friccional se inicia ao passo que os ganchos das fibras são alongados e arrancados até o final do processo (EF).
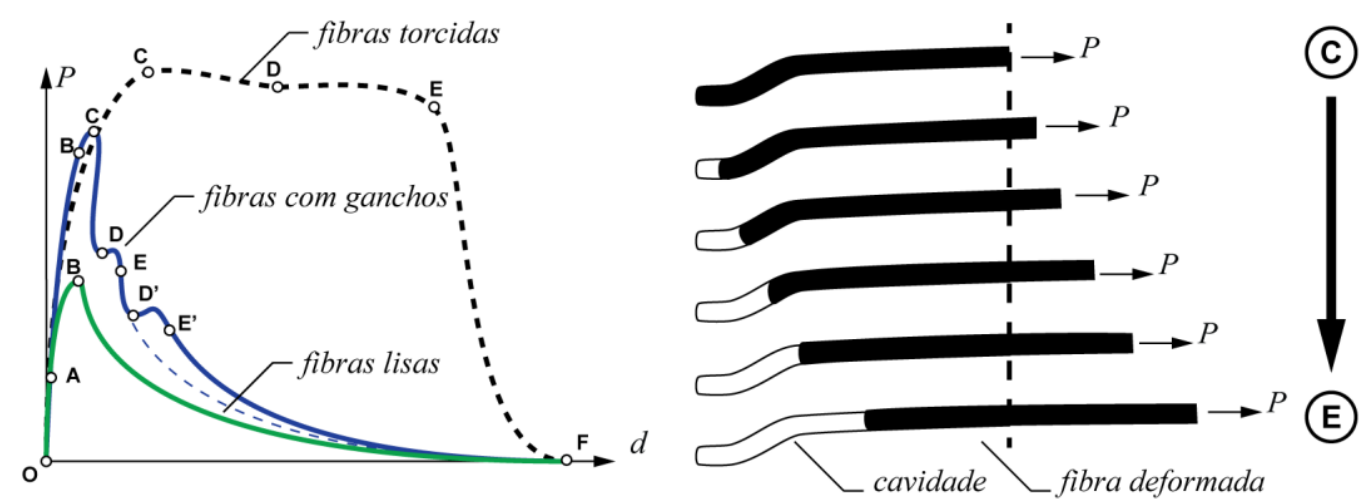

Figura 10 - Curva típica dos ensaios carga versus deslizamento das fibras de aço; adaptado de [16, 54].

Durante o arrancamento das fibras, ocorrem efeitos destrutivos na matriz. O primeiro se destina às deformações plásticas ocorridas nas superfícies das fibras sujeitas ao arrancamento e o segundo à flexão local induzida pela inclinação das fibras com respeito ao plano de carregamento. Estes efeitos reduzem a eficiência dos sistemas fibrosos, que são altamente sensíveis à resposta das matrizes rígidas à flexão local (vide Figura 11). Quando o ponto de escoamento da fibra é alto, ocorre maior dano na matriz, necessitando, portanto, de um balanço entre as propriedades da fibra e matriz para que se obtenha um comportamento mecânico ótimo. 
a)

antes do escorregamento

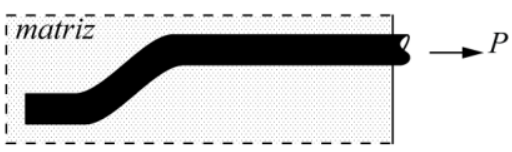

depois do escorregamento

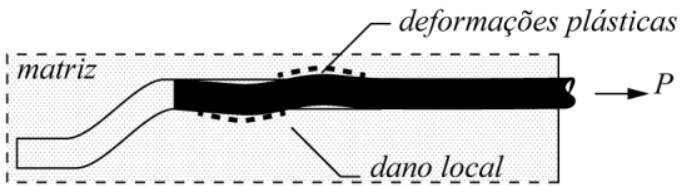

b)

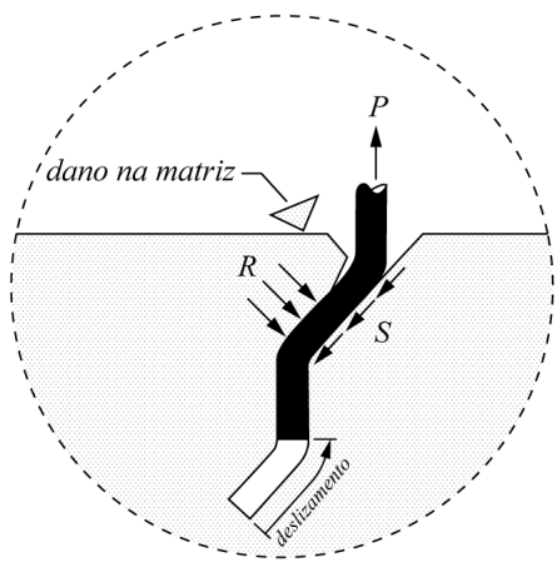

Figura 11 - llustração: a) do processo de dano na matriz em fibras sujeitas à tração; b) do processo de fratura na matriz quando as fibras são sujeitas ao cisalhamento e flexão; adaptado de $[54,16]$

\subsection{6}

\section{Mecanismos de fissuração}

Materiais cimentícios como o concreto possuem por natureza uma estrutura porosa e grande número de microfissuras antes mesmo que the seja aplicado qualquer esforço. Mehta \& Monteiro [17] citam que esta estrutura porosa é representada por um conjunto de vazios de diversas formas e tamanhos, comumente representados por poros, falhas, vasos capilares e por microfissuras presentes na ITZ. Muitas destas fissuras são causadas por segregação, fissuração ou expansão térmica da matriz cimentícia. Segundo van Mier \& Jan [55], durante o carregamento ocorre a interligação das microfissuras preexistentes com outras fissuras que surgem na ligação frágil entre os agregados e a matriz. Ainda segundo van Mier \& Jan [55], este sistema de microfissuras cresce e se propaga rapidamente através dos vazios e falhas, sendo responsável pelo comportamento não linear dos materiais cimentícios à tração. Uma vez sob compressão, os concretos de classes estruturais apresentam modo de falha menos quebradiço, sendo necessária maior energia para que as fissuras progridam em número e tamanho. Segundo Mobasher [56], após o surgimento da primeira fissura as tensões são transferidas por meio de pontes formadas entre as fibras e as fissuras, contribuindo para o mecanismo de mudança de rigidez destas regiões. Com o dispêndio de mais energia, após a carga de pico, as fibras são progressivamente arrancadas em um mecanismo combinado de descolamento, fricção superficial e arrancamento. Muito embora, para que isto ocorra, Mehta \& Monteiro [17] salientam que é necessário que haja 
um equilíbrio entre as resistências da fibra e da matriz, pois caso as fibras tenham adesão fraca com a matriz, elas podem deslizar em baixos níveis de carga e não contribuir significativamente para transferência de tensões. Por outro lado, se a adesão com a matriz for muito forte, a maioria das fibras pode fraturar antes que dissipem energia por arrancamento.

Ao contrário dos concretos simples, os concretos reforçados com fibras de aço não apresentam modo de ruptura frágil. Além disso, a capacidade de deformação é aumentada significativamente após o ponto crítico, ou de pico. A porção total de energia absorvida antes do surgimento da primeira fissura é chamada de tenacidade, representada pela área sobre a curva tensãodeformação específica $(\sigma-\varepsilon)$; e a porção de energia que relaciona a tensão para abertura de fissuras é chamada de energia de fratura, representada pela área sob a curva tensão-abertura de fissuras $(\sigma-w)$. Quando não há utilização de fibras, as microfissuras crescem até se tornarem fissuras passantes, na qual a resistência da matriz cai para zero. Quando são adicionadas fibras, Li et al. [57] observaram um processo de transferência de tensões e dissipação de energia conjunto com as pontes de agregados, até que seja alcançado todo o comprimento efetivo de ancoragem das fibras (vide Figura 12).

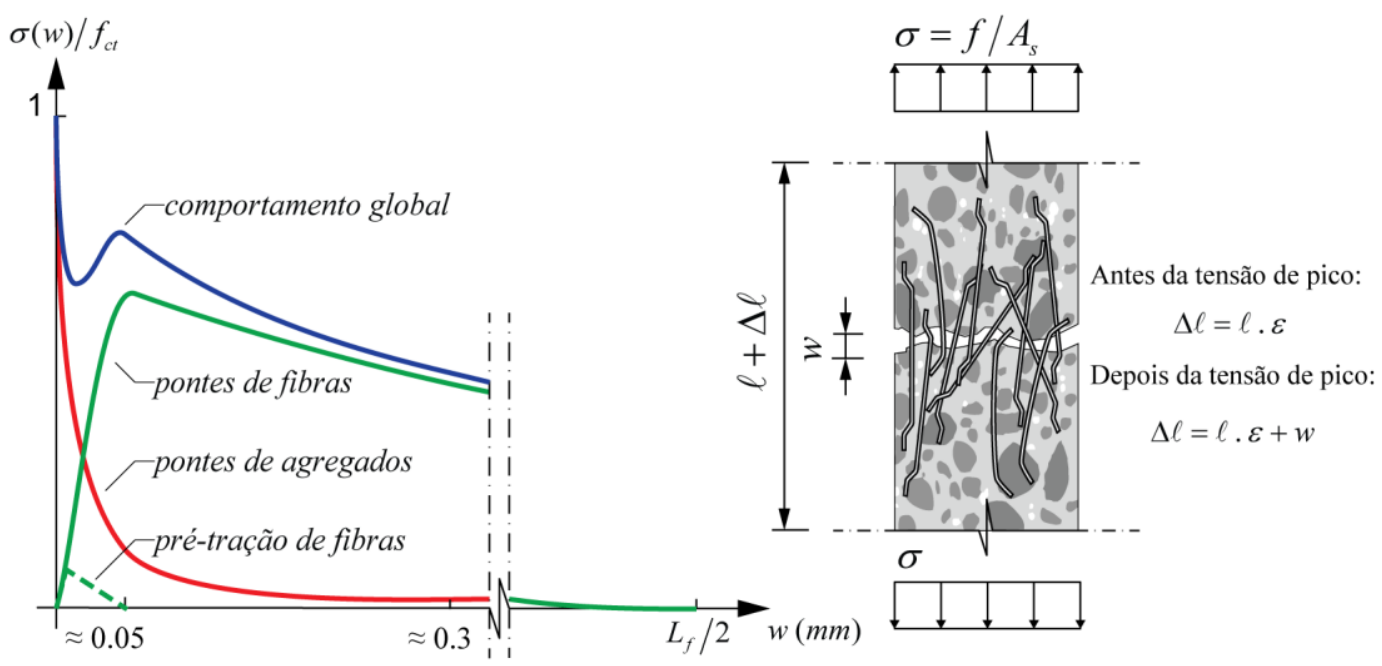

Figura 12 - Detalhe esquemático do comportamento dos SFRCs à tração; adaptado de Li et al. [57].

O processo de fissuração do concreto é um fenômeno complexo, no qual o comportamento e mecanismos ainda não são totalmente conhecidos. Em geral, se aceita que as fissuras evoluam na coalescência das microfissuras presentes 
na matriz em conjunto com as fissuras formadas nas suas interfaces, onde os mecanismos de progressão das fissuras na matriz são influenciados pela presença de agregados e/ou das fibras [58, 59, 60, 61, 62]. As dimensões da região fissurada estão relacionadas com a energia de fratura, e segundo Ohtsu [63], varia com a microestrutura, com o diâmetro e rugosidade do agregado, com a taxa de carregamento e, com a forma do corpo de prova. Segundo Shi [64], os mecanismos de fissuração incluem a microfissuração, as mudanças de direção das fissuras, a ramificação de fissuras, a coalescência de fissuras, o descolamento de agregados e o arrancamento de fibras. Estes mecanismos inelásticos de enrijecimento coexistem com a fissura principal, enquanto a mesma se propaga. Em termos práticos, van Mier \& Jan [55] descrevem o processo de fratura dos concretos reforçados com fibras de aço submetidos à tração direta em quatro estágios:

O) estágio elástico;

A) microfissuração (estável);

B) macrofissuração (instável) e;

C) processos de ponte e intertravamento.

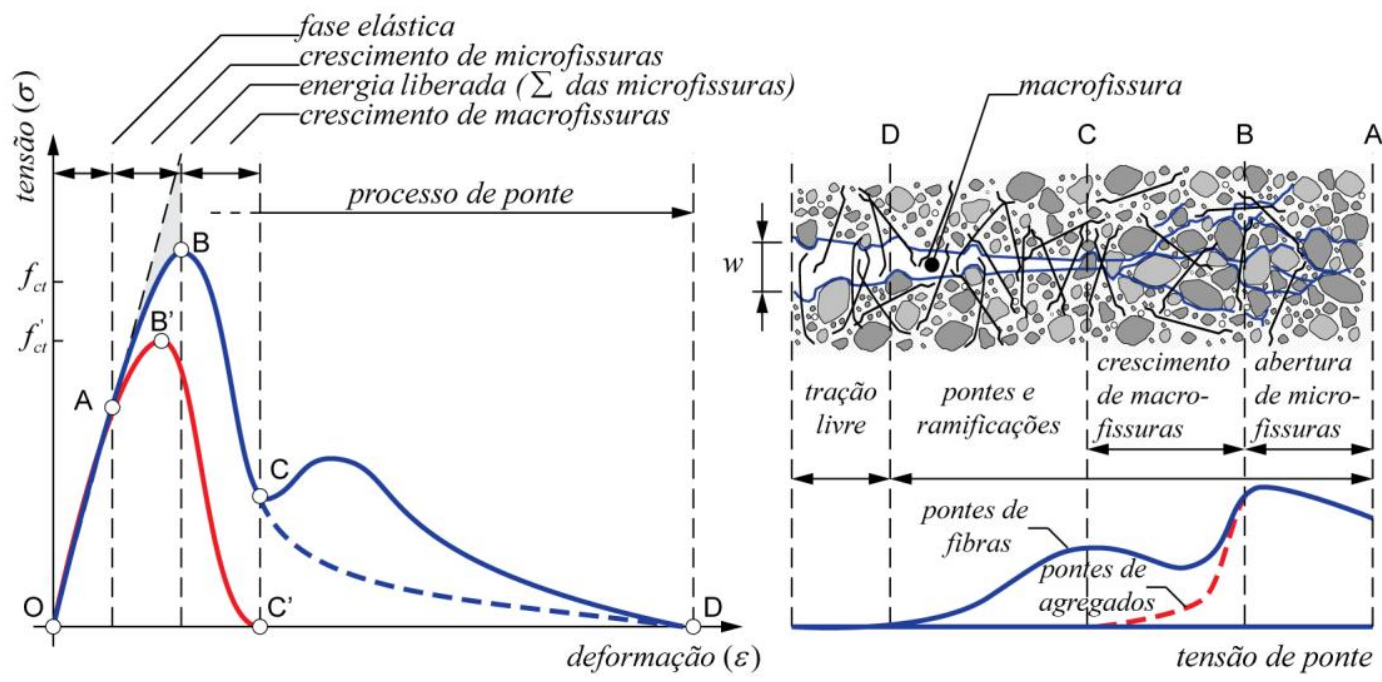

Figura 13 - Detalhe esquemático do efeito das pontes de fibras e agregados no processo de fratura dos SFRCs à tração adaptado de $[65,47,55]$.

O estágio elástico é representado por uma fase linear inicial que ocorre entre a origem e o limite de proporcionalidade (ponto A da Figura 13). Neste estágio, e até mesmo depois de se alcançar a tensão máxima (ponto B), as microfissuras ainda não serão visíveis, pois o dano no concreto é baixo ou 
ausente no nível macroscópico. Depois de alcançado este limite, surgem microfissuras nas regiões onde se concentram as deformações e, por razão do concreto ser constituído essencialmente de duas fases, ocorrem diferentes resistências à propagação dessas microfissuras nas fases da pasta cimentícia e dos agregados. Foi observado por Ohtsu [63], que como resultado disto, as fissuras não se propagam de uma vez, mas aumentam de extensão e param repetidas vezes, sendo eventualmente resistidas pelos agregados. Esta é a razão da parte não linear no ramo descendente do gráfico. Quando a progressão da fissura se interrompe, surgem novas microfissuras em regiões mais frágeis, que em coalescência com outras existentes em torno do plano de fratura, ligam falhas e vazios existentes na pasta cimentícia, tornando-se instáveis e, eventualmente ocasionam a ruptura da amostra (ponto C'). Dependendo da composição, o crescimento da fissura pode se estabilizar, causando decréscimo progressivo de energia ou até mesmo o aumento de energia absorvida por certo período de tempo com o "enrijecimento" da região de ponte, que é posteriormente degradada pelo arrancamento das fibras, a partir do ponto (C), e até que se esgote a capacidade resistente da amostra (ponto D).

\subsection{7 \\ Comportamento à compressão}

As curvas tensão-deformação dos concretos simples exibem um comportamento linear elástico até cerca de $30 \%$ da sua resistência última à compressão axial, então as curvas seguem por um comportamento gradual de softening descrito por van Mier \& Jan [55], até que ocorra a ruptura por esmagamento. Por meio de observações experimentais, van Mier \& Jan [55] sugeriram que a falha por compressão em nível macroscópico ocorre por escorregamento friccional ao longo de falhas preexistentes, resultando em fissuras de tração e no progresso das pontas dessas falhas. As fissuras se iniciam com o deslizamento da interface cimento-agregado da pasta (zona mais frágil) e, se propagam na matriz como fissuras de tração; estas tensões de tração, por sua vez, crescem com o incremento da carga e se tornam paralelas à direção das tensões principais de compressão. A falha ocorre com a interação dessas fissuras de tração, que se iniciam em estágios muito iniciais de carga.

O comportamento à compressão do concreto muda com o incremento de resistência se tornando cada vez mais quebradiço. Um concreto de resistência 
normal possui agregados significativamente mais resistentes e rígidos que a própria pasta cimentícia, enquanto concretos de alta resistência possuem resistência e rigidez semelhantes. Como resultado, Löfgren [65] cita, que neste caso algumas fissuras se estendem por entre os agregados, resultando em uma superfície fissurada mais suave quando comparada às tortuosas dos concretos de resistências normais.

Segundo Bentur \& Mindess [16], a influência da adição das fibras nas propriedades dos materiais compósitos cimentícios é menos efetiva quando sobre compressão, melhorando sensivelmente sua resistência relativa de negligenciável, nos concretos contendo quantidade normal de fibras de aço ( $V_{f}<2 \%$ ), e até próximo de $30 \%$ nos concretos de ultra-alta resistência, como os RPCs (4\% de fibras em volume), o $\operatorname{SIMCON}\left(V_{f} \geq 5 \%\right)$ e o SIFCON $V_{f}>10 \%$ ); cujo comportamento geral dos concretos simples e de alta resistência podem ser observados na Figura 14.

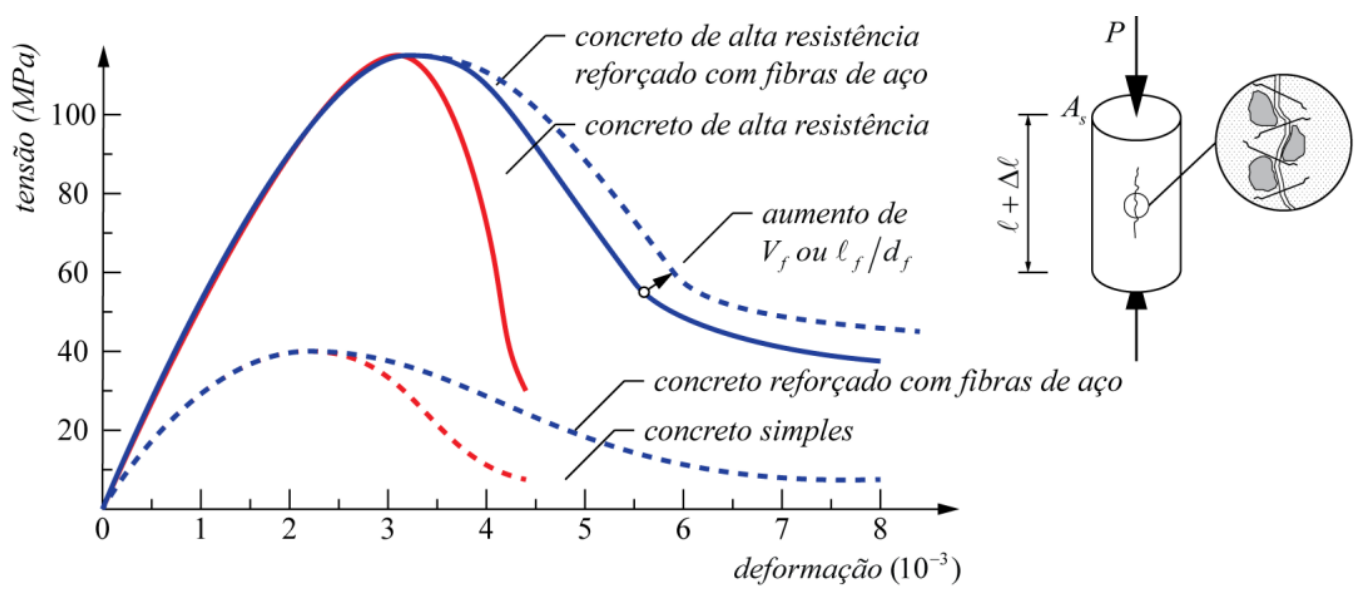

Figura 14 - Gráfico esquemático dos concretos comuns e reforçados com fibras sobre compressão axial; adaptado de $[9,16,65,66]$.

Naaman e Homrich [67] obtiveram a resistência característica à compressão de $200 \mathrm{MPa}$ com o SIFCON formado a partir de uma matriz de $90 \mathrm{MPa}$ com $12 \%$ de fibras de aço. Porém, foi citado por Wille et al. [68] que o alto custo do material envolvido com a utilização de volume considerável de fibras e tempo de preparação tornou desvantajosa a aplicação prática do SIFCON. 
Wille et al. [68] creditaram à de Larrard e Sedran [69] a utilização do termo "Concreto de Ultra-alto Desempenho" (UHPC) para denominar um concreto com teor a/c de 0,14 com alta quantidade de material ligante, resultando na resistência à compressão de $165 \mathrm{MPa}$ sob condições normais de cura. Também pode ser citado o desenvolvimento de altas resistências características à compressão os concretos obtidos com emprego de condições de cura especiais, em conjunto com a utilização de fibras de uma ou mais dimensões, a exemplo do DSP introduzido por Banche [70], dentre outros produtos comerciais como o Densit $^{\circledR}$, Ductal $^{\circledR}$, e Ceracem $^{\circledR}$.

Quando se trata dos SFRSCCs com volumes de fibras menores que 2,0 \%, a resistência à compressão se mostra muito próxima à da própria matriz. Marangon [26] reportou o incremento de 1,5 a $12 \%$ na resistência à compressão axial de concretos autoadensáveis reforçados com fibras de aço de $35 \mathrm{~mm}$, em uma matriz de $80 \mathrm{MPa}$ contendo as frações volumétricas de fibras de aço de 1 a $2,0 \%$. As fibras utilizadas neste estudo tinham razão de aspecto 64 e ganchos nas pontas. Neste estudo não se observaram incrementos consideráveis de rigidez, porém as deformações máximas correspondentes às resistências de pico tiveram incrementos de até $12 \%$ com relação àquela da mistura de referência. Utilizando uma matriz semelhante à do estudo desenvolvido por Marangon [26], Rambo [32] observou da redução de $9 \%$ até um aumento de aproximadamente $24 \%$ na resistência à compressão, quando utilizou de 1,0 a $1,5 \%$ de fibras lisas de aço de comprimento $12 \mathrm{~mm}$ hibridizadas com fibras de aço providas de ganchos com comprimento $35 \mathrm{~mm}$. Ambos os autores [26, 32] não observaram influência significativa no módulo elástico à compressão, pois os resultados se encontraram dentro do intervalo de desvios-padrão.

É sabido que o aumento da quantidade de agregados influencia na rigidez dos concretos, mas foi reportado por Khayat [71] que, embora os SCCs possuam menor quantidade de agregados, eles apresentam módulos parecidos com os concretos simples, pois há grande quantidade de pasta em compensação. Embora seja necessário um volume muito considerável de fibras para que se obtenha incremento significativo nas resistências à compressão, as fibras aumentam substancialmente a ductilidade pós-fissuração ou a absorção de energia do material. Estes efeitos podem ser observados graficamente nas curvas tensão-deformação dos SFRCs contidas na ACI 544.4R [40], no qual a 
tenacidade à compressão também é aumentada ao passo que se aumenta a razão de aspecto e volume das fibras (vide Figura 15a e Figura 15b).

a)

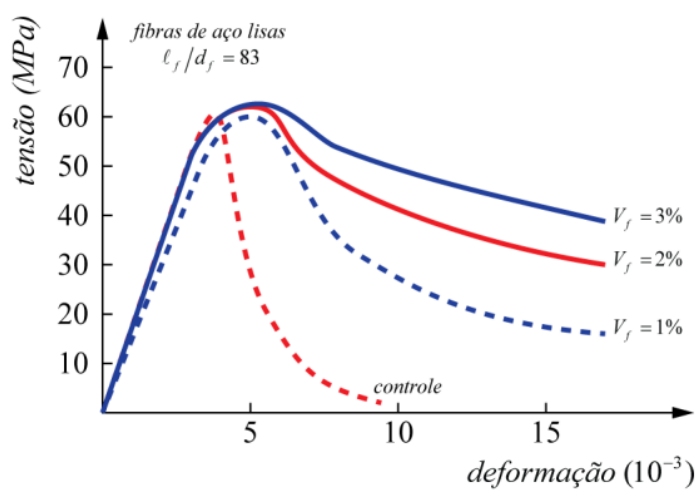

b)

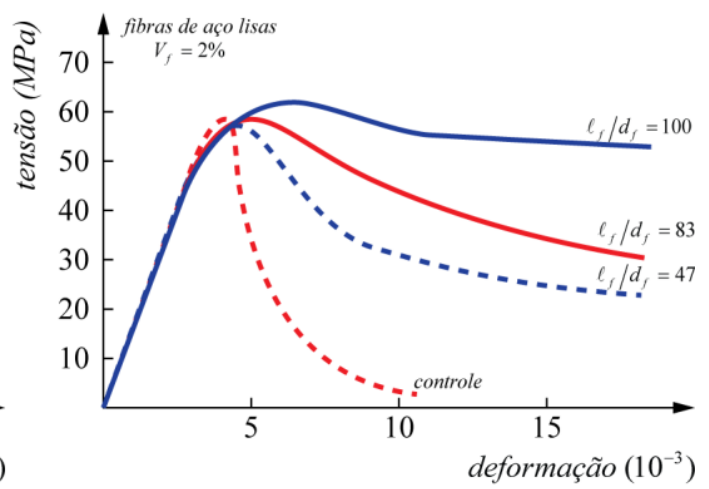

Figura 15 - Gráficos tensão-deformação à compressão para observação da influência do volume e razão de aspecto das fibras de aço; adaptado da ACI 544.4R [40].

\subsection{8}

\section{Comportamento à tração}

Segundo van Mier \& Jan [55], espera-se que a resistência à tração dos concretos não signifique mais do que $10 \%$ da sua resistência correspondente à compressão. Este desequilíbrio entre as resistências à tração e à compressão é tradicionalmente levado em conta por meio do uso de aço como reforço nos locais onde se localizam as maiores forças de tração nas estruturas. Quando o reforço é realizado por meio do emprego de fibras de aço, o incremento na resistência à tração é mais significante do que aquele que ocorre na compressão. Porém, os resultados variam, pois não existe um ensaio normalizado para se determinar a curva tensão-deformação do concreto à tração. Além disto, os ensaios de tração direta dependem de diversos fatores como dimensões e forma dos corpos de prova; do controle e método de ensaio; da rigidez da máquina de ensaios; dos graus de liberdade dados às extremidades dos corpos de prova; da resolução dos transdutores de deslocamento e; se uma única ou múltiplas fissuras ocorrem dentro do intervalo de controle cobertos pelos transdutores $[40,55]$.

Embora sejam relevantes os efeitos de escala (vide [72, 73]), as amostras utilizadas nos ensaios de tração possuem comprimentos limitados, cuja distribuição de tensões nem sempre é ideal, pois a força aplicada não está 
infinitamente distante para promover tensões perfeitamente homogêneas na seção central do elemento de concreto. Além disto, o método utilizado para fixar as amostras nas máquinas de ensaios por colagem ou mordedura pode implicar em efeitos negativos como imperfeições de alinhamento e concentração de tensões nos corpos de prova. Nos casos práticos, procura-se evitar estes efeitos empregando-se ensaios de tração indireta. O ACI 554.2R [74] recomenda a utilização do método de ensaio brasileiro (ASTM C496 [75]) para caracterizar os concretos reforçados com fibras de aço à tração. A resistência à tração indireta, por sua vez, pode ser relacionada com a resistência à compressão por meio de relações empíricas [76, 77]. Embora este ensaio seja simples, há uma dificuldade para se interpretar o resultado do ensaio depois da primeira fissura, uma vez que as distribuições de tensões não são conhecidas. Além disto, a ACI 554.2R [74] cita que a identificação da primeira fissura no corpo de prova pode ser difícil de ser detectada, podendo ser feita com utilização de métodos sofisticados, como a emissão acústica ou holografia a laser. Wille et al. [78] ressaltam ainda, que os ensaios de tração apresentam um desafio, contendo dificuldades para manter uma resposta carga-deslocamento e carga-abertura de fissuras estável, limitando como consequência o número de pesquisas com realização de ensaios de tração direta em materiais cimentícios. Outros ensaios de tração indireta podem ser citados como o Double Edge Wedge Splitting [79, 80] e o Double Punch Test [81, 82].

Foi observado por Li et al. [46], que quando o corpo de prova tem uma das suas dimensões menor que o comprimento das fibras empregadas, a orientação das fibras se limita em seu respeito e, quando o processo de lançamento se dá ao longo do eixo longitudinal do elemento de concreto, as fibras são induzidas a uma posição favorável em termos de eficiência. A geometria dos corpos de prova utilizados para se determinar a resistência à tração dos materiais cimentícios variam principalmente com respeito às suas dimensões, cujas extremidades são normalmente alargadas por razão da ancoragem dos elementos na máquina de ensaios. A transição destas duas partes costuma ter curvatura para dentro ou para fora, sendo projetada para ser suave, assumindo a forma de osso (ou dog bone shaped). van Mier \& Jan [55] afirmam, que esta geometria reduz a possibilidade de que as primeiras fissuras ocorreram distantes da seção central monitorada pelos equipamentos de aquisição de deslocamento, mas não resolve os problemas relativos com a estabilidade, que são contornados pela inserção de entalhes nas amostras. Os entalhes executados 
nos corpos de prova reduzem de maneira efetiva as instabilidades ocorridas na sua ruptura e melhoram em consequência a leitura dos deslocamentos para cálculo efetivo das deformações. De maneira geral, as formas dos corpos de prova utilizados nos ensaios de tração direta podem ser agrupadas em corpos de prova tipo dog bone shaped (Tabela 1), prismáticos ou cilíndricos sem entalhe (Tabela 2a) e prismáticos ou cilíndricos com entalhes (Tabela 2b). Segundo Wille et al. [78], os ensaios também podem ser descritos em função dos dispositivos de fixação, que podem dar liberdade de rotação aos corpos de prova, influenciando diretamente no comportamento à tração. 
Tabela 1 - Configurações típicas dos ensaios de tração direta com amostras tipo dog bone shaped; adaptado de [78]

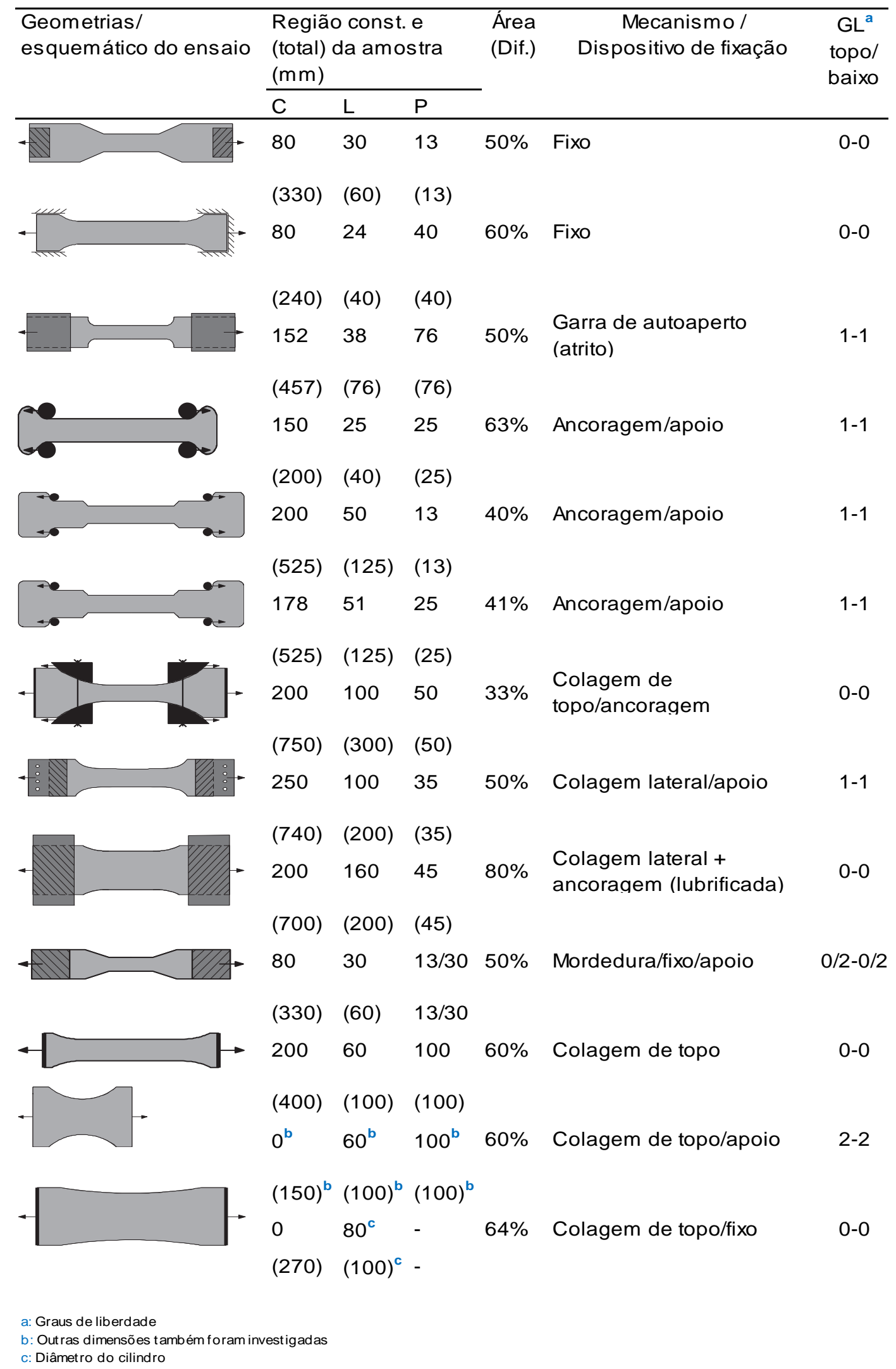


Tabela 2 - Configurações típicas dos ensaios de tração direta com amostras cilíndricas/prismáticas: a) sem entalhe; b) com entalhe; adaptado de [78]

a)

\begin{tabular}{lllcc}
\hline $\begin{array}{l}\text { Geometrias/ } \\
\text { esquemático do ensaio }\end{array}$ & $\begin{array}{l}\text { Região const. e } \\
\text { (total) da amostra } \\
(\mathrm{mm})\end{array}$ & $\begin{array}{l}\text { Área } \\
\text { (Dif.) }\end{array}$ & $\begin{array}{c}\text { Mecanismo/ } \\
\text { Dispositivo de fixação }\end{array}$ & $\begin{array}{c}\mathrm{GL}^{\mathrm{a}} \\
\text { topo/ } \\
\text { baixo }\end{array}$ \\
\cline { 2 - 3 } & $\mathrm{C} \quad \mathrm{L} \quad \mathrm{P}$ & & \\
\hline
\end{tabular}

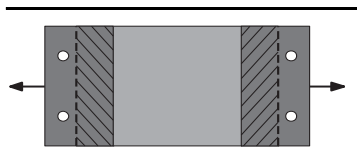

$\begin{array}{lllll}127 & 127 & 28 & 100 \% & \text { Colagem lateral/apoio } \quad 0\end{array}$

(330) (127) (28)

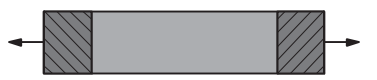

$20576 \quad 13 \quad 100 \%$ Colagem lateral/apoio 0-0

(305) (76) (13)

$10251 \quad 51 \quad 100 \%$ Colagem lateral +

$0-0$

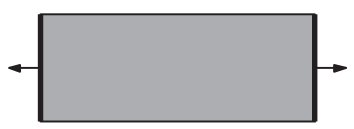

(432) (51) (51)

$16070 \quad 70 \quad 100 \%$ Colagem de topo

$0-0$

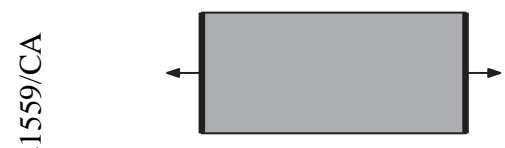

(160) (70) (70)

$200100^{c}-100 \%$ Colagem de topo

$0-0$

(200) (100) $)^{c}-$

b)

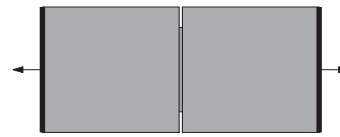

2

$44 \%$ Colagem de topo

$0-0$

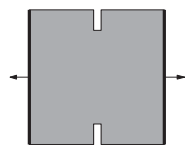

(152) (76) (76)

3

$42 \quad 50$

$70 \%$ Colagem de topo

$0-0$

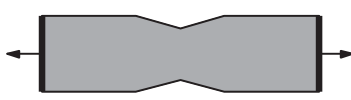

(55) (60) (50)

151

$51 \quad 13$

$67 \%$ Colagem de topo

$0-0$

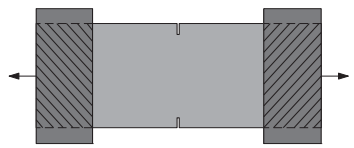

(254) (76) (13)

$\sim 5 \quad 160 \quad 50$

$80 \%$

Colagem lateral + ancoragem (lubrificada)

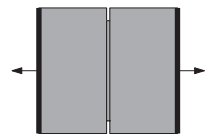

(500) (200)

(50)

$2-5 \quad 135^{c}-$

$81 \%$ Colagem de topo

$0-0$

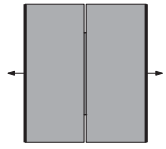

(150) (150) $)^{c}$ -

$244^{\mathrm{c}}-$

$35 \%$ Colagem de topo

0-0

(60) $\quad(74)^{\mathrm{c}} \quad-$ 
Os corpos de prova formados por materiais cimentícios quando submetidos à tração, apresentam comportamentos de strain-softening ou de strain-hardening. Os materiais que possuem o comportamento de strainsoftening apresentam comumente uma única fissura localizada, seguido de um comportamento pós-pico no qual a tensão resistente decresce. Os materiais que apresentam o comportamento de strain-hardening, por sua vez, são denominados como materiais compósitos cimentícios de alto desempenho reforçados com fibras (HPFRCC); e são caracterizados (ou definidos) como de alto desempenho, porque suas curvas tensão-deformação mostram um comportamento de strain-hardening, isto é, possuem resistência pós-fissuração maior que aquela observada à primeira fissura, no fim da fase elástica. A parte ascendente das curvas tensão-deformação dos concretos reforçados com fibras é semelhante ao da matriz, até primeira fissura $(O A)$. A parte pós-pico (ascendente ou descendente $A-B$ ) depende dos parâmetros do reforço como a forma, quantidade e razão de aspecto das fibras, sendo altamente influenciada por sua orientação e distribuição [46, 83]. A parte final das curvas dos ensaios de tração segue com regime de softening, até que seja dissipada toda a energia pelo arrancamento friccional das fibras de aço $(\mathrm{BC})$, cujo comportamento geral pode ser observado na Figura 16.

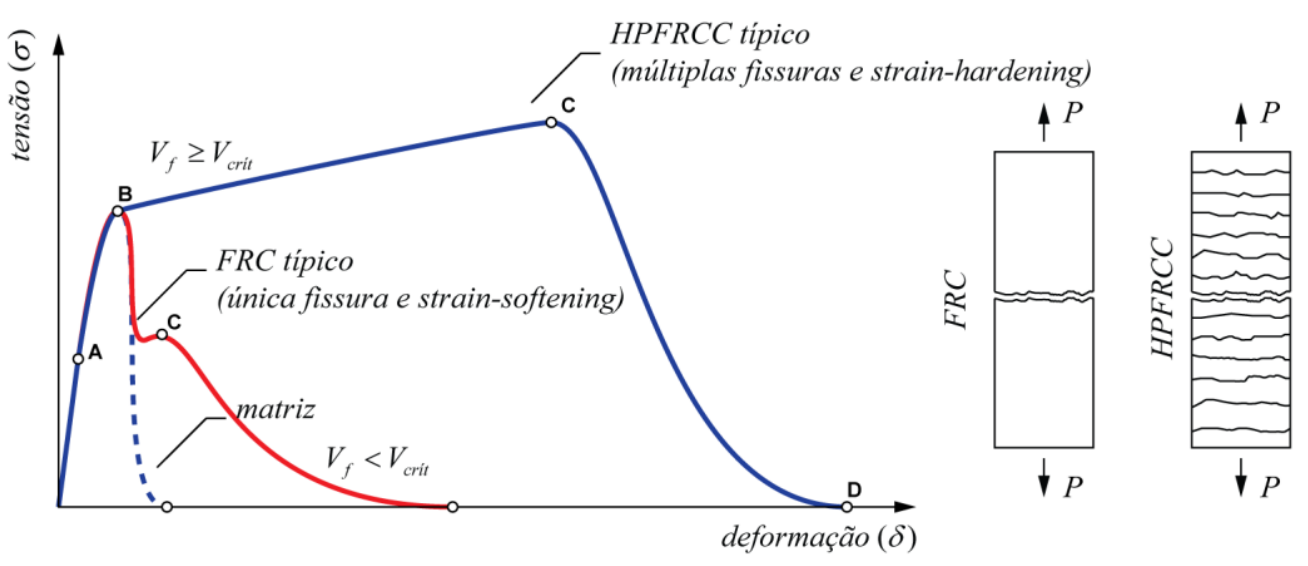

Figura 16 - Comportamento típico dos FRCs e HPFRCCs sob tração direta; adaptado de $[67,84,83]$.

A resistência à tração dos concretos reforçados com fibras de aço na tração direta é geralmente da mesma ordem de grandeza do concreto simples, isto é, de 2 a $4 \mathrm{MPa}[40,85]$. Entretanto, sua tenacidade é maior para frações relativamente baixas $\left(V_{f}<2 \%\right)$ por razão do aumento da energia dissipada 
durante o arrancamento das fibras em ambos os lados de uma ou das múltiplas fissuras formadas durante a deformação. Naaman e Homrich [67] observaram resistência à tração direta do SIFCON em $20 \mathrm{MPa}$, sugerindo a significância de 15 a $25 \%$ com relação à sua resistência à compressão axial. Neste estudo os autores utilizaram a fração volumétrica de $12 \%$ de fibras de aço com ganchos de $30 \mathrm{~mm}$ e razão de aspecto 60 , dispersas em uma matriz de $90 \mathrm{MPa}$. Murakami e Zeng [86], por sua vez, realizaram experimentos em pequenas placas tracionadas de SIMCON e observaram que, para a mesma fração volumétrica e fibras alinhadas, o SIMCON teve desempenho superior ao SIFCON na fração de $4,6 \%$, pois a distribuição de fibras do SIFCON não é uniforme por razão do método típico de lançamento por aspersão.

Segundo Wille et al. [68], o desenvolvimento recente dos UHPCs com resistências à compressão maiores que $150 \mathrm{MPa}$ proporcionou em consequência uma grande força de adesão entre as fibras e a matriz. Ainda segundo Wille et al. [68] a conjugação do UHPC com fibras de alta resistência, possibilitou alcançar altas resistências e ductilidade à tração para percentuais volumétricos relativamente pequenos, sendo reportado o comportamento de strain-hardening acompanhado de múltipla fissuração a partir da fração volumétrica de $1 \%$. Estes concretos têm resistências à tração da ordem de $15 \mathrm{MPa}$, deformações na tensão de pico excedendo $0,3 \%$ e quantidade de fibras não excedendo $2,5 \%$ em volume [68].

As tentativas para melhorar o comportamento à tração dos UHPFRCs, principalmente no que concerne à sua capacidade de deformação à tração, tem sido dada pelo aumento da quantidade de fibras ou pelo uso do HFRC, cujo reforço é promovido por mais de um tipo de fibra [87, 88]. Wille et al. [68] apontam, que se busca alcançar deformações à tração da mesma ordem de grandeza daquelas consideradas para as armaduras convencionais, utilizandose o menor consumo de fibras de aço possível.

Wille et al. [68] utilizaram uma matriz com resistência característica à compressão de $200 \mathrm{MPa}$ em conjunto com fibras de alta resistência para compor UHPFRCs. Foram utilizadas neste estudo de três geometrias de fibras de aço em frações volumétricas menores que $2,5 \%$. Os tipos de fibras estudados foram lisas, com ganchos e torcidas. Utilizando-se fibras lisas de relação $\ell_{f} / d_{f}=13 / 0,2$, nas frações volumétricas de 1,5 a $2,5 \%$, resultou-se em 
resistências à tração do compósito de 8 a $14 \mathrm{MPa}$, com incrementos na deformação de pós-fissuração correspondente à carga de pico de 0,17 a 0,24 \%. Utilizando-se fibras com ganchos nas extremidades de relação $\ell_{f} / d_{f}=30 / 0,38$, nas frações volumétricas de 1,0 a 2,0\%, por sua vez, resultou-se em resistências à tração do compósito de 9 a $14 \mathrm{MPa}$, enquanto que a deformação máxima de pós-fissuração permaneceu em torno de 0,46 \%. Uma vez utilizandose fibras torcidas de relação $\ell_{f} / d_{f}=30 / 0,30 \mathrm{com} 16$ nervuras ao longo do seu comprimento, observou-se que para as frações volumétricas de 1,0 a 2,0\%, obtiveram-se resistências à tração de 8 a $15 \mathrm{MPa}$, com incrementos na deformação de pós-fissuração de 0,33 a 0,61\%; e com as fibras torcidas contendo 6 nervuras ao longo do seu comprimento, na fração de 1,5\%, alcançou-se a resistência à tração de $13 \mathrm{MPa}$, com deformação na zona de pósfissuração de $0,60 \%$.

Em outro estudo realizado com UHPFRC contendo as mesmas fibras do estudo mencionado anteriormente, Wille et al. [89] utilizaram uma matriz de $240 \mathrm{MPa}$ infiltrada para formar o SIFCON, cuja incorporação de $8 \%$ de fibras torcidas resultou em um compósito de resistência à compressão de $292 \mathrm{MPa}$ e resistência à tração de $37 \mathrm{MPa}$. Foi obtida ainda a deformação à tração no ponto correspondente à carga de pico maior que 1,1\%. Wille et al. [78] afirmam que a quantidade de energia absorvida antes da fase de tension-softening de $50 \mathrm{~kJ} / \mathrm{m}^{3}$ seja suficiente para caracterizar os UHPFRC. Da mesma maneira, os mesmos autores reportaram para o SIFCON/UHPFRC com fração volumétrica de 5,5\%, a energia absorvida $\mathrm{g}=304 \mathrm{~kJ} / \mathrm{m}^{3}$, enquanto que com um UHPFRC se obteve $\mathrm{g}=125 \mathrm{~kJ} / \mathrm{m}^{3}$ para a fração volumétrica de fibras de apenas $1 \%$. Outros autores conseguiram obter melhor desempenho dos UHPFRC por meio da utilização de um ou mais tipos de fibras hibridizadas. Kang et al. [87] obtiveram em seu estudo resultados favoráveis com a hibridização de fibras de aço com polipropileno, mostrando o incremento de 39 \% na capacidade de deformação e resistência à tração $13 \%$ maior do que aquelas obtidas com a utilização das fibras de aço.

Do ponto de vista prático, deseja-se obter as propriedades do concreto de alto desempenho reforçado com fibras de aço em conjunto com as propriedades do concreto autoadensável. Para isto, autores como Rambo [32] utilizaram matrizes autoadensáveis de alta resistência em conjunto com fibras de aço em pequenas frações volumétricas $\left(V_{f}<2 \%\right)$, híbridas ou não, para manter ambas 
as características dos concretos de alto desempenho e dos concretos autoadensáveis fibrosos. Rambo [32], em seu estudo, o aumento de em torno de 70 \% na resistência à tração, quando se utilizou uma matriz de $80 \mathrm{MPa}$ reforçada com fibras lisas de aço de $12 \mathrm{~mm}$, nas frações volumétricas de 1,0 a 1,5\%. Foi verificado neste mesmo estudo, um aumento significativo da ductilidade pósfissuração, porém o comportamento de strain-hardening não foi alcançado.

Liao [90], por sua vez, obteve o comportamento de strain-hardening com a utilização do SCHPFRC. No seu estudo foram avaliadas matrizes com o intervalo de resistências à compressão axial de 35 a $65 \mathrm{MPa}$ reforçadas com fibras de aço de alta resistência, relação $\ell_{f} / d_{f}=30 / 0,38$, nas frações volumétricas de 1,5 a 2,0\%. Resultou-se a partir destas misturas nas resistências à tração do intervalo de 3,5 a $6,5 \mathrm{MPa}$. Ambas as amostras apresentaram comportamento de strain-hardening acompanhada de múltipla fissuração, com deformação máxima correspondente à carga de pico no intervalo de 0,25 a $0,45 \%$. 


\section{4 .9 \\ Comportamento à Flexão}

Segundo a norma ACI 544.1R [15], a influência da adição de fibras na resistência à flexão dos SFRCs é muito maior que nas resistências à tração e compressão, sendo reportado incrementos de mais de $100 \%$ para argamassas reforçadas com 4,0\% de fibras em volume. Este efeito ocorre por razão do deslocamento progressivo da linha neutra em direção à zona comprimida, que se deve principalmente à carga residual de tração proporcionada pela presença das fibras de aço. A norma ACI 544.4R [40] afirma, que esse aumento de resistência é sensível ao volume de fibras utilizado, sendo desprezível para teores menores que $0,5 \%$. A razão de aspecto é outro fator importante: quanto maior ela for, maior será o incremento da resistência à flexão. Espera-se, segundo a $\mathrm{ACl} 554.8 \mathrm{R}$ [91], que outras características das fibras também alterem o comportamento à flexão em termos da energia total absorvida como a natureza da sua ancoragem (lisa, com ganchos, torcidas), bem como sua orientação e distribuição. Em geral, os FRCs apresentam o comportamento de deflection-softening ou deflection-hardening. Esta classificação proposta por Naaman e Reinhardt [92] estende a resposta mecânica à tração direta para o comportamento à flexão, porque que a maioria das características da resposta de softening e hardening obtidas nos ensaios de tração também ocorrem na flexão (vide Figura 17).

Pela análise da Figura 17 se observa que o ponto denominado como "de primeira fissura" corresponde à carga na qual a curva tensão-deformação se distancia da linearidade $(\mathrm{OA})$; depois deste ponto, a curva pode ser ascendente ou descendente, apresentando ponto de máximo local ( $A B)$; quando a curva é ascendente, o ponto que caracteriza a carga máxima obtida em todo o ensaio é chamada de resistência última à flexão ou módulo de ruptura (C) [40, 92]. A energia total absorvida é chamada de tenacidade, definida como área sob o gráfico carga-deflexão dos ensaios de flexão sobre carga estática [15, 40].

Para a finalidade de comparação do desempenho dos SFRCs, foram definidos índices de tenacidade (vide ASTM C1018 [93]), que são obtidos por meio da divisão da área sobre a curva carga-deflexão em trechos múltiplos da deflexão do ponto de primeira fissura. A norma ASTM C1609 [6] utiliza o termo "desempenho" para designar o conjunto de parâmetros utilizados para 
caracterizar os SFRCs, como a carga de primeira fissura, a carga máxima de pico, as cargas residuais e a tenacidade.

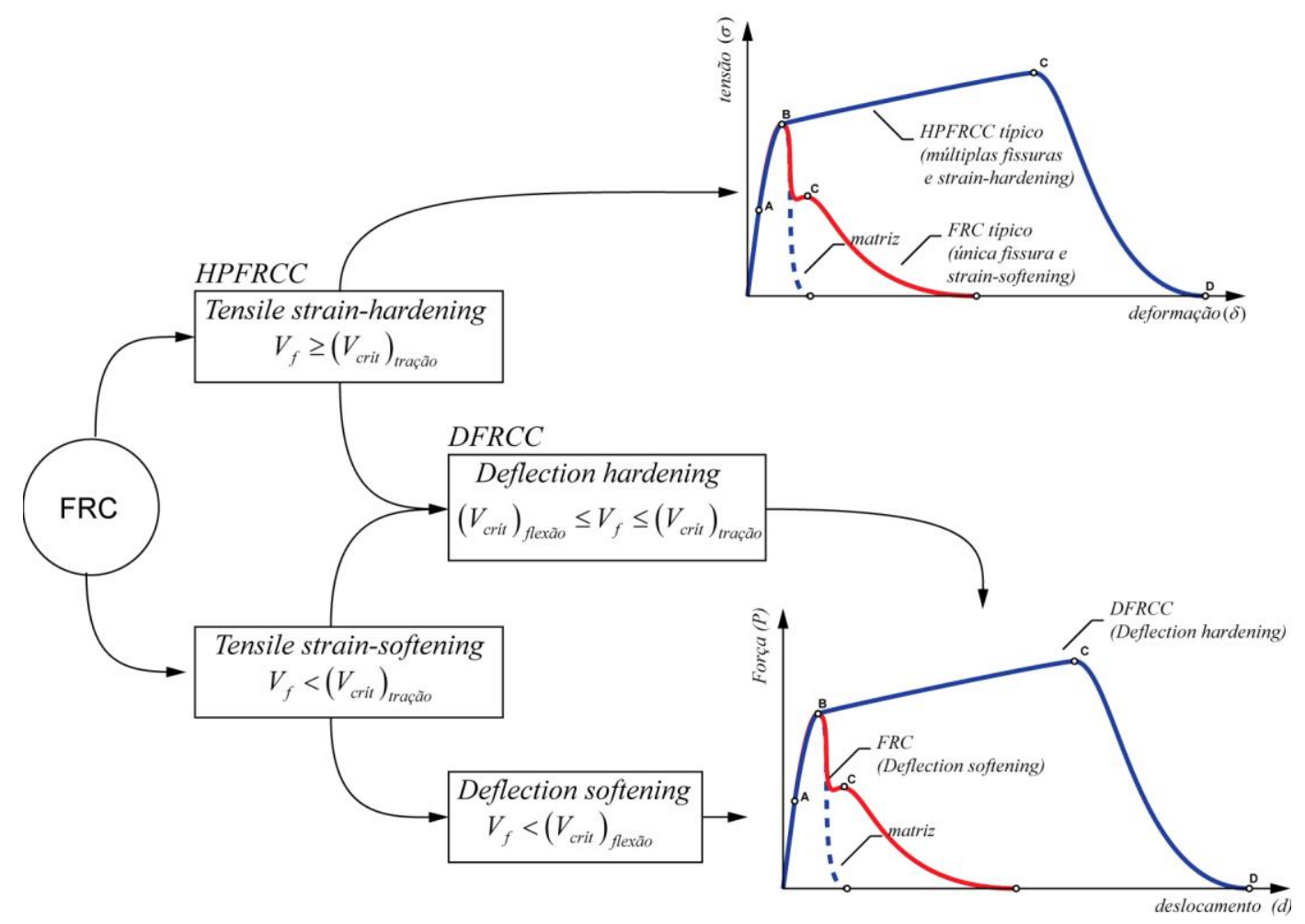

Figura 17 - Classificação dos FRCs baseada no comportamento à tração como de alto desemprenho ou dúctil; adaptado de Naaman \& Reinhardt [92].

A norma ACI 554.8R [91] reporta que as dificuldades para realização dos ensaios de flexão se associam à: instabilidade da propagação das fissuras de um lado para o outro do corpo de prova, implicando na não uniformidade das deformações; à dificuldade dos procedimentos de operação da máquina de ensaios; ao método de controle utilizado nos ensaios com amostras frágeis e que apresentam crescimento súbito das fissuras; às condições de contorno impostas, livres ou fixas no entorno; às instabilidades e dificuldades de ensaiar amostras grandes; às diferenças de resultados entre as geometrias e dimensões; às dificuldades para execução de entalhes; dentre outras.

Kim et al. [94] realizaram flexão em quatro pontos em corpos de prova formados por uma matriz de argamassa de resistência à compressão de $56 \mathrm{MPa}$ reforçada com $1,2 \%$ de fibras de aço em volume, obtendo para ambos o comportamento de deflection-hardening. Neste estudo, foram utilizadas fibras torcidas com relação $\ell_{f} / d_{f}=30 / 0,3$ e fibras com ganchos de relação 
$\ell_{f} / d_{f}=30 / 0,38$, resultando em resistências à tração na flexão à primeira fissura de 2,6 MPa e resistência última aproximada de $12 \mathrm{MPa}$.

Chanvillard e Rigaud apud Bentur \& Mindess [16] reportaram que, em alguns RPCs, as resistências à flexão podem alcançar $60 \mathrm{MPa}$ com utilização de reforço na fração volumétrica de fibras de 2,4\% e $102 \mathrm{MPa}$ com $8 \%$ de fibras. Com Ductal ${ }^{\circledR}$ (outro RPC), Wei et al. [95] reportaram resistências à flexão da ordem de $60 \mathrm{MPa}$, quando se utilizou fibras de $13 \mathrm{~mm}$ de comprimento e diâmetro $0,175 \mathrm{~mm}$, na fração volumétrica de $4 \%$.

No caso dos SFRSCCs, Marangon [26] observou o comportamento de deflection-hardening, aumento da carga máxima de ensaio, maior ductilidade e tenacidade. Neste estudo, não se observou, porém aumento considerável na deflexão correspondente à primeira fissura. No que diz respeito à carga máxima na fase de pós-fissuração, os aumentos percentuais observados variaram de 54 a $113 \%$, com deslocamentos correspondentes à carga máxima acrescidos em $28 \%$ quando comparados com aqueles obtidos na mistura de referência. As fibras de aço utilizadas neste estudo possuíam ganchos nas pontas, $35 \mathrm{~mm}$ de comprimento e razão de aspecto 64. A matriz utilizada neste estudo possuía resistência característica de $80 \mathrm{MPa}$ e foram analisados os reforços de 1 a $2 \%$ fibras de aço em volume. Utilizando como base a matriz utilizada no estudo desenvolvido por Marangon [26], Rambo [32] e Rambo et al. [88] observaram cargas máximas nos ensais de flexão incrementadas de forma expressiva, variando de 70 à $133 \%$, quando comparadas à matriz. Utilizou-se neste estudo, os percentuais volumétricos de 1,0 a $1,5 \%$ de fibras lisas de aço de comprimento $12 \mathrm{~mm}$, hibridizadas com fibras de aço providas de ganchos de comprimento $35 \mathrm{~mm}$, com razões de aspecto de 67 e 65, respectivamente.

Buscando avaliar os efeitos da hibridização de fibras de aço e polipropileno, Pająk [96] utilizou em seu estudo três frações volumétricas de fibras de aço, em conjunto com dois outros tipos de fibras de polipropileno. A matriz utilizada para formar o compósito tinha resistência à compressão de $85 \mathrm{MPa}$ e $5 \mathrm{MPa}$ de resistência de tração na flexão. Pająk [96] constatou, que o aumento da fração volumétrica das fibras de aço de 0,5 até 1,5\% resultou nos incrementos de resistência máxima à flexão de 40 a $55 \%$. Quando se utilizou hibridização com os volumes de 0,3 e $0,9 \%$ de fibras de polipropileno, por sua vez, se obtiveram resistências últimas à flexão aumentadas de 55 a $70 \%$. Foi 
reportado, entretanto, que os concretos que continham maior volume de fibras longas de polipropileno tiveram sua reologia prejudicada. As fibras de aço incluídas neste estudo tinham superfície corrugada e comprimento de $35 \mathrm{~mm}$, enquanto as fibras de polipropileno tinham os comprimentos de 19 e $38 \mathrm{~mm}$.

\subsubsection{0}

\section{Comportamento de elementos estruturais à flexão}

Diversos métodos têm sido propostos como alternativa para caracterizar os FRCs com respeito à tenacidade e resistência à tração. Uma abordagem utiliza o cálculo reverso, que se baseia em uma metodologia de análise inversa dos resultados dos ensaios de flexão; outra utiliza a determinação de índices de tenacidade para avaliar o desempenho dos concretos (vide ASTM C1018 [93]). $\mathrm{O}$ método mais utilizado para se determinar a resistência residual à flexão e também para avaliar as propriedades da fratura dos concretos é o ensaio de flexão em três pontos em prismas com entalhes (vide RILEM TC 162-TDF [97], EN 14651 [98], CEB-FIB [66] e Mobasher et al. [99]). Porém, segundo Minelli e Plizzari [100], há evidências que nas frações volumétricas mais utilizadas na prática $(<1,0 \%)$, os valores de resistência à flexão determinados por meio de corpos de prova prismáticos sejam consideravelmente menores que a média, por razão da grande dispersão dos resultados de ensaios. Minelli e Plizzari [100] observaram ainda, que esta dispersão não tem relação com o material em si, mas se deve principalmente à pequena área de fissuração que é ligada por um pequeno número de fibras (de 160 a $190 \mathrm{~cm}^{2}$ ).

Para se avaliar a tenacidade dos SFRCs recomenda-se utilizar os ensaios de flexão em painéis quadrados ou circulares (vide EFNARC [101] e ASTM C1550 [1]). Estes ensaios são tipicamente utilizados para caracterizar os concretos projetados, no qual o método de ensaio pode simular as condições específicas de carregamento consideradas no projeto estrutural. Segundo Minelli et al. [100], estes ensaios mostram uma variação muito menor do que aquelas obtidas nos ensaios de flexão de prismas de pequenas dimensões - além de se eliminar a necessidade de se executar entalhes; mas possuem como desvantagem a difícil execução, pois as dimensões dos corpos de prova são consideráveis, dificultando sua manipulação e transporte. Ainda no estudo de Minelli e Plizzari [100] observou-se que, ao se considerar painéis de $600 \mathrm{~mm}$ ao invés do painel preconizado pelo ASTM C1550 [1] de 800 mm, não se implicou 
em maior variabilidade dos resultados. Os mesmos autores ressaltaram ainda, que não há normas que orientem a determinação analítica das propriedades da fratura relacionadas com este ensaio, sendo necessária sua elaboração.

Segundo Bentur \& Mindess [102], o uso de fibras de aço foi sugerido inicialmente para ser utilizado como reforço das estruturas em que houvesse chance de exposição à cargas de alta intensidade ao longo da sua vida útil, como cargas de impacto ou explosão. Esta recomendação se justifica pela observância de que a adição de fibras aumenta a resistência e ductilidade das matrizes frágeis, promovendo um reforço tridimensional quando dispersas aleatoriamente na matriz. Sob cargas estáticas, entretanto, as estruturas armadas com barras de aço possuem reforço mais eficiente, pois são posicionadas para coincidir com a direção das forças de tração.

Bentur \& Mindess [102] investigaram as propriedades do concreto armado e reforçado, buscando-se explorar as vantagens do uso ótimo de ambos os materiais. Neste estudo os autores submeteram à flexão oito vigas de $0,10 \times 0,10 \times 1,00 \mathrm{~m}$, com diferentes esquemas de reforço de barras. As barras de aço utilizadas na armação possuíam $6,0 \mathrm{~mm}$ de diâmetro e o SFRC utilizado era formado a partir de um reforço com fibras de aço de relação $\ell_{f} / d_{f}=50 / 0,50$. Bentur \& Mindess [102] observaram, então, que a adição da fração volumétrica de fibras de 1,5\% promoveu aumento da carga de pico à flexão em $62 \%$, com relação à viga de referência. Quando utilizaram o reforço com SFRC em conjunto com as armaduras longitudinais, o incremento observado na carga máxima de ensaio foi de $55 \%$, com relação à viga armada de referência (sem reforço). Ainda neste mesmo estudo, foi verificado que a adição do reforço fibroso resultou no aumento da rigidez à flexão, resultando em menores deflexões para o mesmo nível de carga. O padrão de fissuras observado nas vigas armadas e reforçadas com fibras por foi associado com a diminuição das espessuras e com o aumento no número de fissuras.

Bischoff et al. [103] conduziram um estudo objetivando investigar o efeito do uso de fibras para melhorar o desenvolvimento do escorregamento no trespasse de barras de aço, utilizando duas vigas de dimensões 0,22x 0,33 $\times 3,00 \mathrm{~m}$, sem estribos no seu terço médio. Em ambas as vigas se utilizou um concreto de resistência à compressão axial de $80 \mathrm{MPa}$ e 4,3 MPa à tração. Observou-se, por meio dos ensaios de flexão em quatro pontos, que o elemento 
estrutural concretado concreto simples rompeu bruscamente na carga que correspondia ao escoamento das barras de aço $(2 \Phi 25,2 \mathrm{~mm})$, por razão da falta de aderência. Em contrapartida, se observou no ensaio de flexão da viga reforçada com $0,5 \%$ de fibras o incremento da capacidade de carga em $18 \%$, com manutenção das deformações além daquela observada na viga de referência. As fibras utilizadas neste estudo possuíam ganchos, comprimento de $60 \mathrm{~mm}$ e razão de aspecto 80 . Os mesmos autores observaram ainda, que a adição de fibras de aço aumentou a resistência pós-fissuração e a aderência das barras de aço com o concreto, por meio do efeito conjunto de redução das tensões desenvolvidas na flexão com o melhor confinamento promovido pelo controle da abertura de fissuras.

Em um programa de ensaios mais extenso, Altun et al. [104] analisaram dezoito vigas moldadas com SFRCs formados a partir de matrizes das classes C20 e C30 e resistências à tração de 1,59 e 1,95 MPa, respectivamente. As fibras utilizadas foram semelhantes às utilizadas no trabalho de Bischoff et al. [103]. Os ensaios de flexão em quatro pontos das vigas armadas com um par de barras de aço de $16 \mathrm{~mm}$ e dimensões $0,30 \times 0,30 \times 2,0 \mathrm{~m}$, resultaram nos incrementos de carga máxima à flexão de até $14 \%$ para a classe C20 e, de $30 \%$ para a classe $\mathrm{C} 30$, contendo $60 \mathrm{~kg} / \mathrm{m}^{3}$ de fibras de aço. Da mesma maneira que Bischoff et al. [103], Altun et al. [104] observaram que o reforço de fibras homogeneamente dispersas ajudou a distribuir melhor as tensões, resultando em fissuras de menor magnitude.

Buscando analisar a influencia do tipo e da quantidade de fibras de aço no comportamento à flexão do SFRCs, Holschemacher et al. [105] ensaiaram pequenas vigas de concreto de 0,15 $\times 0,15 \times 0,7 \mathrm{~m}$ armadas com dois arranjos distintos de barras de aço $(2 \Phi 6 \mathrm{~mm}$ e $2 \Phi 12 \mathrm{~mm}$ ). Todas as vigas foram concretadas com um SFRC formado a partir de uma matriz de resistência à compressão axial de $80 \mathrm{MPa}$ reforçada com fibras de aço de comprimento 50 mm e $1 \mathrm{~mm}$ de diâmetro (duas com ganchos de resistências diferentes e uma corrugada). As frações estudadas foram de 20,40 e $60 \mathrm{~kg} / \mathrm{m}^{3}$, no qual se observaram diferentes modos de falha para as vigas contendo taxa de armadura de $1 \%$ ( $2 \Phi 12 \mathrm{~mm}$ ). Para as pequenas quantidades de fibras ( 0 a $20 \mathrm{~kg} / \mathrm{m}^{3}$ ), as vigas apresentaram falha por cisalhamento ou compressão, enquanto que as vigas que continham as quantidades de fibras de 40 a $60 \mathrm{~kg} / \mathrm{m}^{3}$ apresentaram falha principalmente por compressão. Observaram-se para as demais vigas os 
modos de falha à flexão motivada pela deformação excessiva das barras de aço. De forma geral, as vigas reforçadas com as diferentes fibras tiveram comportamento semelhante, com sensível vantagem quando reforçadas com as fibras corrugadas. $\mathrm{O}$ incremento de resistência à flexão ficou dentro do intervalo de 5 a $10 \%$, na carga correspondente ao início da formação de fissuras e. quanto maior foi a quantidade de fibras empregadas, menor foi a dispersão dos resultados.

Barakat e Altoubat [106] propuseram uma solução para contornar as dificuldades envolvidas na produção de elementos pré-moldados de grandes comprimentos, atendendo ao mesmo tempo à demanda arquitetônica para se produzir grandes vãos e resolver os problemas relacionados com o transporte e movimentação destes elementos. A técnica consiste em formar um único elemento a partir da ligação de outras duas partes com concreto reforçado com fibras de aço. Neste estudo objetivou-se avaliar a capacidade de carga última e o desenvolvimento das fissuras nestes elementos, comparando-as com as obtidas nas vigas de referência. Determinou-se o comprimento ótimo da região de ligação entre as partes do elemento pré-moldado e a fração de fibras ideal para esta aplicação. Para concretagem dos elementos pré-moldados foi utilizado um concreto de resistência à compressão axial de $35 \mathrm{MPa}$ e para concretagem das regiões de ligação, utilizou-se esta mesma matriz reforçada com fibras de aço com ganchos de comprimento $30 \mathrm{~mm}$ e $0,55 \mathrm{~mm}$ de diâmetro, nas frações volumétricas de 2,0 e $3,0 \%$. As armaduras consistiam em duas barras longitudinais de diâmetro $12 \mathrm{~mm}(2 \Phi 12 \mathrm{~mm})$, com reforço ao cisalhamento promovido por estribos de $8 \mathrm{~mm}$ espaçados a cada $200 \mathrm{~mm}$, excetuando-se a região de ligação. Por meio dos ensaios de flexão em quatro pontos em uma série de 26 elementos, concluiu-se que a ligação de $300 \mathrm{~mm}$ concretada com SFRCs na fração volumétrica de fibras de $2,0 \%$ pôde ser qualificada como opção viável para a técnica de ligação entre o concreto novo e o concreto velho.

Para o caso dos SFRSCCs, Ning et al. [107] testaram os efeitos da adição de fibras de aço no comportamento à flexão de vigas armadas. Foram utilizadas vigas de dimensões $0,20 \times 0,30 \times 2,4 \mathrm{~m}$ e armadas com pares de barras de aço de 16, 18 e $20 \mathrm{~mm}$, cujas taxas geométricas de armaduras correspondentes são: $0,76 \%(2 \Phi 16 \mathrm{~mm}), 0,96 \%(2 \Phi 18 \mathrm{~mm})$ e $1,18 \%(2 \Phi 16 \mathrm{~mm})$. As vigas possuíam estribos de diâmetro $6,5 \mathrm{~mm}$ posicionados a cada $80 \mathrm{~mm}$, com interrupção no vão central. As fibras utilizadas como reforço proviam de ganchos 
nas extremidades, comprimento $60 \mathrm{~mm}$ e diâmetro $0,75 \mathrm{~mm}$. As séries de vigas foram concretadas com uma matriz de $60 \mathrm{MPa}$ reforçada com as quantidades de fibras de aço de 30 e $50 \mathrm{~kg} / \mathrm{m}^{3}$. Depois de realizados os ensaios de flexão em quatro pontos para os dois conteúdos de fibras e para cada uma das três taxas geométricas estudadas, concluiu-se que a capacidade de carga última à flexão aumentou consideravelmente com o incremento de fibras, sendo identificado um volume de fibras que se equivale a uma taxa geométrica de armaduras de 0,2\%. 


\section{3 \\ Programa experimental}

\section{1 Introdução}

O desdobramento deste estudo se deu pela análise da influência da adição de fibras de aço dispersas em uma matriz de concreto autoadensável. Foram utilizados três tipos de fibras, nas frações volumétricas de 0,5, 1,0 e 2,0 \%. O traço de concreto autoadensável utilizado neste estudo foi desenvolvido por Marangon [26] com auxílio do software BetonlabPro2, que utiliza o conceito do empacotamento compressivo. O presente trabalho se iniciou com a reprodução do concreto autoadensável, levando-se em conta os materiais e recursos disponíveis no LEM (Laboratório de Estruturas e Materiais da PUC-Rio). A fim de se obter maior fidelidade com traço produzido no trabalho anterior (vide Marangon [26]), foram adquiridos insumos com características semelhantes aos originalmente utilizados e mantiveram-se os fornecedores de aditivos e adições. Posteriormente realizaram-se ajustes na dosagem e se estabeleceu um processo de mistura que resultava em características reológicas préestabelecidas.

O concreto de referência, bem como cada uma das famílias de traços de concretos autoadensáveis reforçados com fibras de aço foram caracterizadas no estado fresco e endurecido. Para caracterizar estas misturas no estado fresco, utilizou-se o ensaio de espalhamento modificado. E no estado endurecido, os ensaios de caracterização compreenderam a determinação da compressão axial de corpos de prova cilíndricos, a determinação do módulo elástico à compressão, a determinação da tração direta e da determinação da resistência à flexão.

Depois de realizado o programa de ensaios de caracterização, foram realizados ensaios semiestruturais de flexão em painéis circulares e estruturais de flexão em vigas curtas armadas. Nos ensaios de flexão em painéis circulares objetivou-se observar a evolução da energia de deformação com o aumento da 
fração volumétrica de uma fibra, confrontando-se seu desempenho com as demais séries. Nos ensaios de vigas curtas armadas, analisou-se a influência do reforço fibroso quando conjugado com armaduras convencionais. Para isto, foram ensaiadas vigas em três taxas distintas de armaduras, para a mistura de referência e para o concreto reforçado com a fração volumétrica de $2 \%$ de fibras de aço.

Para cada série ensaiaram-se três corpos de prova, onde cada exemplar foi representado pela média dos resultados individuais. Os corpos de prova de concreto foram identificados pelo tipo de fibra de aço utilizado no reforço, pelo percentual volumétrico empregado e pelo sequencial de moldagem.

A nomenclatura utilizada neste estudo para identificar as séries de corpos de prova consiste na descrição do tipo de fibra, seguido do percentual volumétrico. As fibras torcidas foram identificadas pelas letras "TW" (twisted) e as fibras com ganchos foram identificadas pelas letras "HE" (hooked ends). Portanto, as famílias de traços foram denominadas como:

CAA - 0\% (mistura de referência);

TW 50/25 - 0.5\%, TW 50/25 - 1\% e TW 50/25 - 2\% (misturas com frações volumétricas de $0,5,1,0$ e 2,0 \% de fibras torcidas de comprimento $25 \mathrm{~mm}$ e razão de aspecto 50 );

HE 45/30 - 0.5\%, HE 45/30 - 1\%, HE 45/30 - 2\% (misturas com frações volumétricas de $0,5,1,0$ e 2,0 \% de fibras com ganchos de comprimento $30 \mathrm{~mm}$ e razão de aspecto 45);

HE 80/60 - 0.5\%, HE 80/60 - 1\%, HE 80/60 - 2\% (misturas com frações volumétricas de $0,5,1,0$ e 2,0\% de fibras com ganchos de comprimento $60 \mathrm{~mm}$ e razão de aspecto 80 ). 


\section{2 \\ Materiais utilizados}

\subsection{1}

\section{Material cimentício}

O cimento utilizado para produção da matriz de concreto autoadensável foi cimento Portland CPV ARI do fabricante LafargeHolcim, cujos parâmetros dos lotes recebidos atendiam às condições especificadas na norma NBR 5733 [108].

\subsection{2}

\section{Agregados}

Os agregados utilizados para a fabricação dos concretos foram os agregados miúdos de areia natural quartzosa e agregado graúdo de gnaisse, denominados neste estudo como areia natural e brita 0 . A brita possuía diâmetro máximo de 9,5 mm e módulo de finura 5,41. A areia natural, por sua vez, foi utilizada em duas frações distintas: a primeira fração era representada pelo material passante na peneira $4,75 \mathrm{~mm}$ e retida na peneira $0,85 \mathrm{~mm}$ e; a segunda fração era representada pelo material remanescente retido na peneira $150 \mu \mathrm{m}$. Antes do peneiramento, a areia natural possuía diâmetro máximo de $2,36 \mathrm{~mm}$ e módulo de finura 2,68. A Figura 18a ilustra a composição granulométrica da brita 0 e da areia natural, determinadas de acordo com a NBR NM 248 [109].

\subsection{3}

\section{Adições}

As adições foram a Sílica Ativa SILMIX ${ }^{\circledR}$ tipo D (densificada), as Cinzas Volantes POZOFLY ${ }^{\circledR}$ e um fíler de pó de quartzo, proveniente da indústria cerâmica, denominada neste estudo como Sílica 325. As duas últimas adições tiveram suas composições granulométricas determinadas por granulometria a laser com o equipamento CILAS 1190 (Laboratório de Geotecnia e Meio Ambiente da PUC-Rio) e, a distribuição granulométrica da Ślica Ativa foi realizada pelo Instituto de Pesquisas Tecnológicas e disponibilizada pelo próprio fabricante. A Figura 18b ilustra as composições granulométricas destes materiais. 
a)

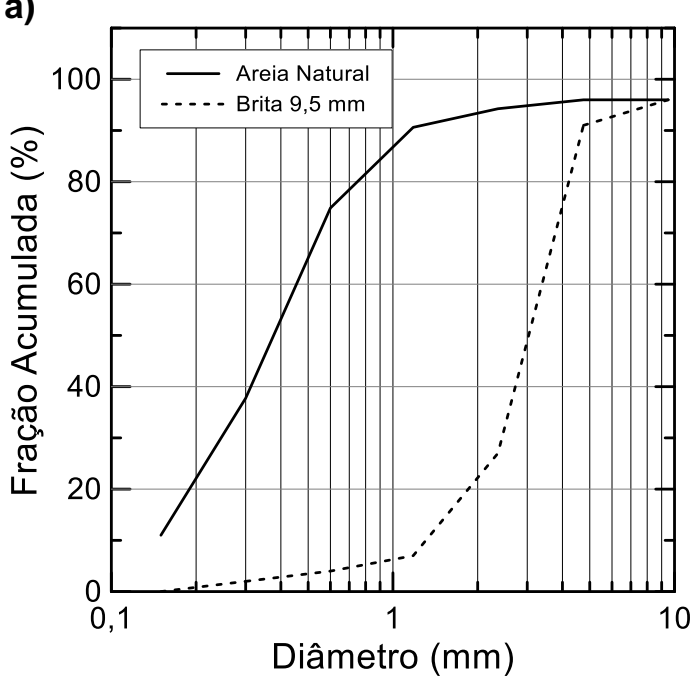

b)

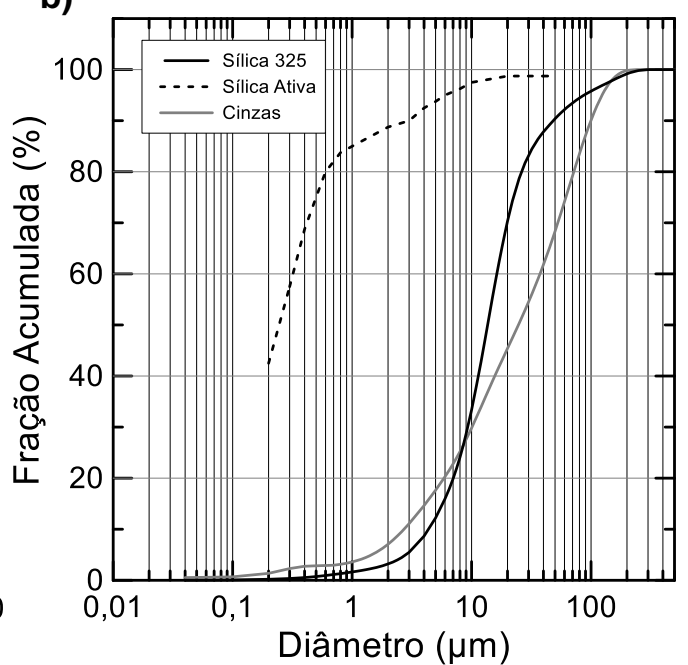

Figura 18 - Gráfico: a) da distribuição granulométrica dos agregados; b) da distribuição granulométrica das adições

\subsection{4}

\section{Aditivo}

O aditivo superplastificante utilizado foi o MasterGlenium ${ }^{\circledR} 51$, que tem base em éter policarboxílico. O aditivo foi produzido pelo fabricante BASF dentro do que estabelece a norma NBR 11768 [110]. Para efeito de cálculo do fator a/c, considerou-se o teor de sólidos dentro do intervalo de controle do fabricante de $30,5 \pm 1,5$, no seu limite inferior.

\subsection{5}

\section{Fibras de aço}

As fibras de aço utilizadas neste trabalho possuíam três tipos distintos. A primeira era torcida ao longo do comprimento de $25 \mathrm{~mm}$ e tinha diâmetro $0,5 \mathrm{~mm}$ e as outras duas possuíam ganchos nas extremidades, comprimentos de 30 e $60 \mathrm{~mm}$ e diâmetros de 0,67 e $0,75 \mathrm{~mm}$, respectivamente (vide Figura 19). As propriedades físicas e mecânicas das fibras foram reunidas na Tabela 3.

TW $50 / 25$

HE $45 / 30$

HE 80/60

Figura 19 - Geometria das fibras de aço utilizadas 
Tabela 3 - Propriedades das fibras de aço utilizadas

\begin{tabular}{|c|c|c|c|c|}
\hline \multicolumn{5}{|c|}{$\begin{array}{l}\text { Propriedades das fibras de aço } \\
\text { Propriedades das fibras de aço } \\
\text { presentes em catálogos técnicos dos fabricantes }\end{array}$} \\
\hline & \multicolumn{4}{|c|}{ valores em médios } \\
\hline & Unidade & TW 50/25 & HE 45/30 & HE 80/60 \\
\hline \multicolumn{5}{|l|}{ Físicas e geométricas } \\
\hline Comprimento & $\mathrm{mm}$ & 25 & 30 & 60 \\
\hline Diâmetro & $\mathrm{mm}$ & 0,50 & 0,62 & 0,75 \\
\hline Razão de aspecto & & 50 & 45 & 80 \\
\hline Massa específica & $\mathrm{g} / \mathrm{cm}^{3}$ & 8,05 & 7,85 & 7,85 \\
\hline \multicolumn{5}{|l|}{ Mecânicas } \\
\hline Resistência à tração & $\mathrm{MPa}$ & 1700 & 1270 & 1270 \\
\hline Módulo elástico & $\mathrm{GPa}$ & * & 210 & 210 \\
\hline
\end{tabular}

\section{3}

\section{Ajuste para produção do concreto autoadensável}

O ajuste para produção do concreto autoadensável se iniciou com a avaliação do ponto de saturação de aditivo, determinado por meio do tempo de escoamento para sucessivos teores de aditivo na argamassa do traço, utilizando o cone de Marsh (vide Figura 20). Sabido o limite de $4 \%$ (em relação ao cimento) para maior eficiência do aditivo superplastificante na argamassa do traço, determinou-se o teor de superplastificante que promoveria o espalhamento arbitrado de $650 \mathrm{~mm}$, cujo teor de $5,5 \%$ se mostrou suficiente para obter este espalhamento sem a presença de segregação ou exsudação - tal como o traço original [26]. Em sequência, estabeleceu-se um processo padrão de mistura para o traço (vide Tabela 4) para cada um dos dois equipamentos disponíveis: Betoneira de $400 \mathrm{~L}$ e Misturador Planetário de $20 \mathrm{~L}$. 


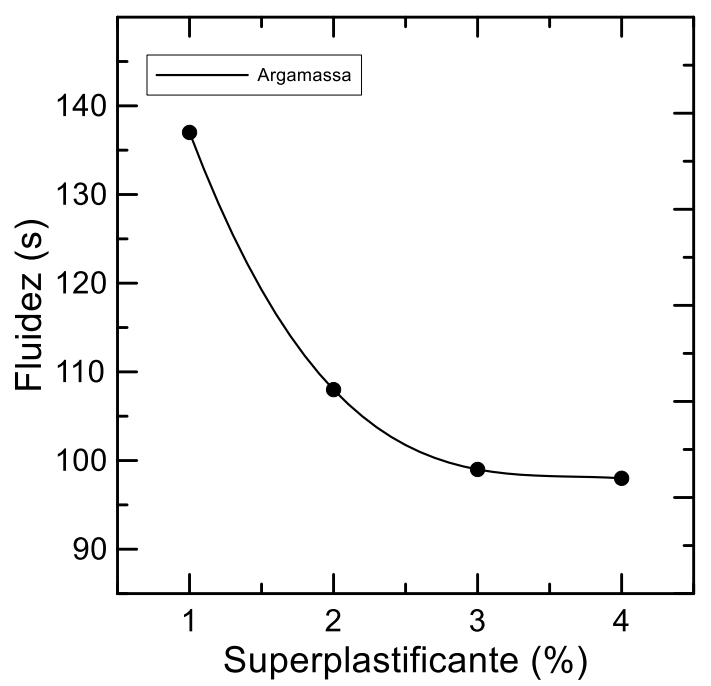

Figura 20 - Índices de fluidez da argamassa do traço para volumes crescentes de aditivo superplastificante

Tabela 4 - Traço do concreto autoadensável

\section{Traço do concreto autoadensável}

Composição padrão da matriz autoadensável

reforçada com fibras de aço em até $2 \%$ do volume

\begin{tabular}{|c|c|c|c|}
\hline \multirow[t]{2}{*}{ Massa aparente: $2247 \mathrm{~kg} / \mathrm{m}^{3}$} & & \multicolumn{2}{|c|}{ valores em massa } \\
\hline & & n fibras & com fibras \\
\hline Cimento CPV ARI & 1,000 & $360 \mathrm{~kg}$ & $360 \mathrm{~kg}$ \\
\hline \multicolumn{4}{|l|}{ Agregados } \\
\hline Areia Natural \# $150 \mu \mathrm{m}$ & 2,305 & $830 \mathrm{~kg}$ & $830 \mathrm{~kg}$ \\
\hline Areia Natural \# 0,85 m m & 0,277 & $100 \mathrm{~kg}$ & $100 \mathrm{~kg}$ \\
\hline Brita 0 & 1,372 & $494 \mathrm{~kg}$ & $468 \mathrm{~kg}$ \\
\hline \multicolumn{4}{|l|}{ Adições } \\
\hline Sílica 325 & 0,194 & $70 \mathrm{~kg}$ & $70 \mathrm{~kg}$ \\
\hline Sílica Ativa & 0,125 & $40 \mathrm{~kg}$ & $40 \mathrm{~kg}$ \\
\hline Cinzas volantes & 0,466 & $168 \mathrm{~kg}$ & $168 \mathrm{~kg}$ \\
\hline Água* & & $180 \mathrm{~kg}$ & $180 \mathrm{~kg}$ \\
\hline Superplastificante & & $20 \mathrm{~kg}$ & $20 \mathrm{~kg}$ \\
\hline Fibras de aço (1\%) & & & $78.5 \mathrm{~kg}$ \\
\hline Relação água/cimento 0,5 & \multicolumn{3}{|c|}{ - Teor de aditivo 5,5\% } \\
\hline Relação água/materiais secos $8,7 \%$ & \multicolumn{3}{|c|}{$\begin{array}{l}\text { - Teor de sólidos do aditivo } \\
32 \%\end{array}$} \\
\hline
\end{tabular}

O processo de mistura consistiu em quatro etapas: na primeira etapa misturavam-se os agregados e cerca de $60 \%$ da água para umedecimento e homogeneização por um minuto; a segunda etapa consistia adicionar os materiais em pó sobre os agregados umedecidos e misturava-se por mais um 
minuto; a terceira etapa consistia em misturar o cimento ao conjunto, formando uma mistura com aparência de argamassa seca após mistura por um minuto; por fim, na quarta etapa, adicionava-se o aditivo superplastificante sobre a mistura pronta, utilizando-se também a parcela remanescente de água. O processo de fabricação se encerrava após a mistura ininterrupta por dez minutos. Quando se utilizaram fibras de aço, as adições foram realizadas gradualmente, utilizando-se cinco minutos adicionais de mistura.

\section{4}

\section{Ensaios do programa experimental}

As fases do programa experimental englobaram os ensaios na escala do material, ensaios semiestruturais e estruturais (vide Figura 21).

\section{Ensaios do programa experimental}

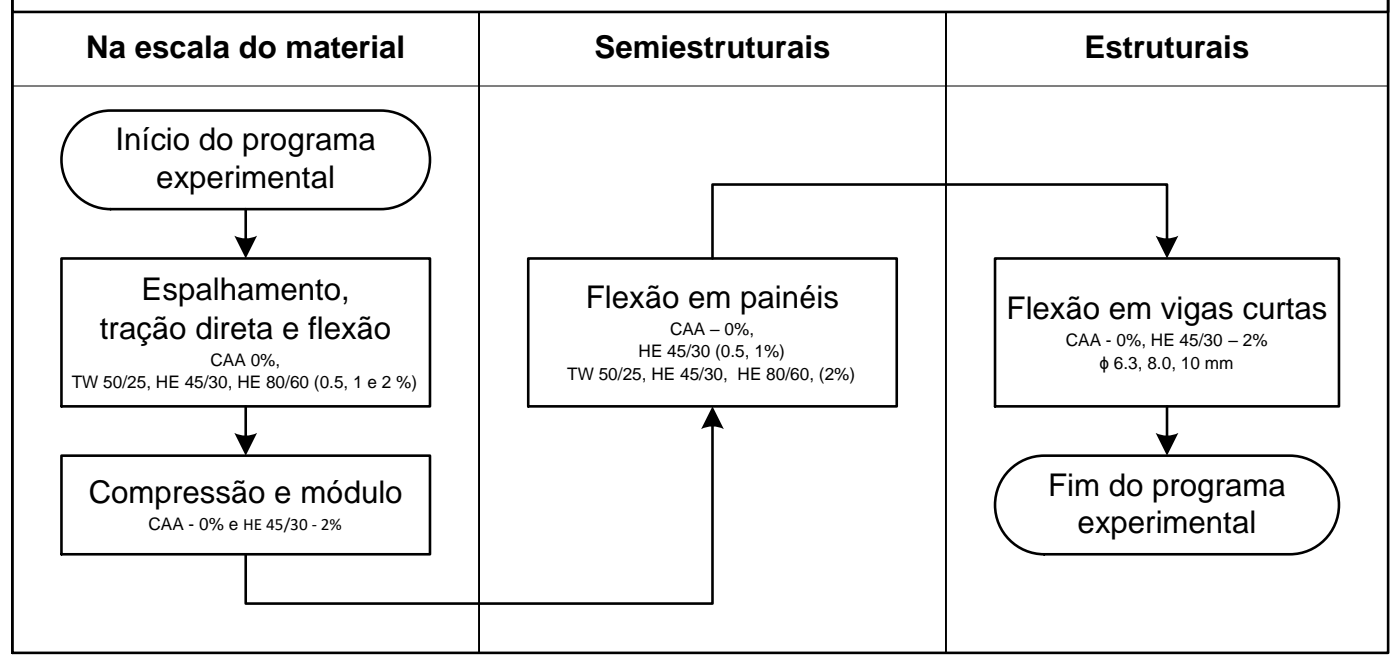

Figura 21 - Fases do programa experimental

\subsection{1}

\section{Ensaios na escala do material}

Os ensaios na escala do material foram representados pelo conjunto de ensaios preliminares utilizados para caracterizar as misturas no estado freso e endurecido. As misturas foram avaliadas no estado fresco pela sua maior ou menor capacidade de fluir por efeito do seu peso próprio e, no estado endurecido, quanto às suas resistências à compressão, tração e flexão. 
O universo amostral e os métodos utilizados para cada ensaio podem ser observados na Tabela 5:

Tabela 5 - Métodos de ensaio e universo amostral

\begin{tabular}{|c|c|c|}
\hline \multicolumn{3}{|c|}{$\begin{array}{l}\text { Métodos de ensaio e universo amostral } \\
\text { Métodos de ensaio } \\
\text { e quantidade de amostras }\end{array}$} \\
\hline & \multicolumn{2}{|c|}{ número de séries / corpos-de-prova } \\
\hline & método & quantidade \\
\hline \multicolumn{3}{|l|}{ Ensaios para ajuste do traço } \\
\hline Determinação do índice de fluidez & ASTM D6910 & 1 \\
\hline Determinação do espalhamento & ASTMC1611 & 1 \\
\hline \multicolumn{3}{|l|}{ Ensaios de caracterização } \\
\hline Determinação do espalhamento & ASTM C1611 & 10 \\
\hline Determinação da resistência à compressão axial & ASTM C39 & $10 / 30$ \\
\hline Determinação do módulo elástico & ASTM C469 & $10 / 30$ \\
\hline Resistência e tenacidade à tração direta & Experimental & $10 / 30$ \\
\hline Resistência à flexão & ASTMC1018 & $10 / 30$ \\
\hline \multicolumn{3}{|l|}{ Ensaios semiestruturais } \\
\hline Tenacidade à flexão us ando painéis circulares & ASTM C1550 & $6 / 18$ \\
\hline Ensaio de flexão em vigas de concreto armado & Experimental & $6 / 6$ \\
\hline
\end{tabular}

\subsubsection{1}

\section{Ensaio de espalhamento modificado}

Os ensaios de espalhamento foram realizados com base na norma ASTM C1611 [3] utilizando-se o cone de Abrams invertido. Para sua determinação, arbitrou-se o teor de aditivo superplastificante de 6,0\% para todas as misturas e frações volumétricas utilizadas, registrando-se os espalhamentos e tempos de escoamento. A Figura 22a mostra as dimensões do cone de Abrams e a Figura 22b as dimensões da placa base utilizada. 
a)
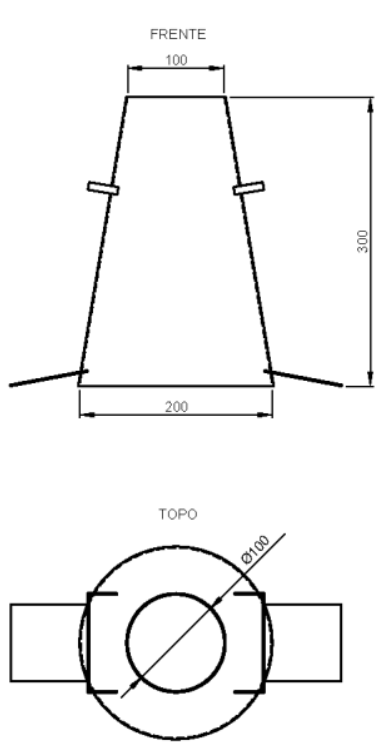

b)

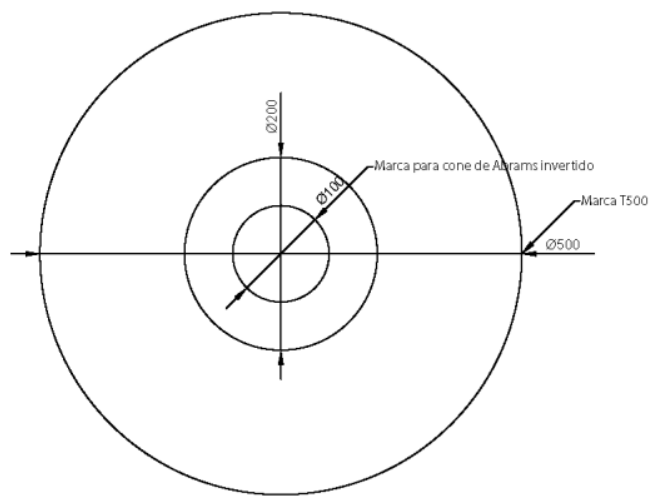

Figura 22 - Ilustração: a) das dimensões do cone de Abrams; b) da placa base para ensaio de espalhamento

\subsubsection{2}

\section{Ensaio resistência e módulo à compressão axial}

Os ensaios de compressão simples e de determinação do módulo de elasticidade à compressão axial foram realizados de acordo com as normas ASTM C39 [4] e ASTM C469 [5], respectivamente. Os corpos de prova foram curados em tanque saturado com hidróxido de cálcio e mantidos em ambiente controlado com temperatura dentro do intervalo de $22 \pm 2{ }^{\circ} \mathrm{C}$. Todos os corpos de prova tiveram suas superfícies planificadas com máquina retífica provida de abrasivo diamantado. Utilizou-se nestes ensaios a máquina de testes da fabricante CONTROLS modelo MCC8, com capacidade máxima de 2000 kN.

\subsubsection{3}

\section{Ensaio de tração direta}

Os ensaios de tração direta foram realizados utilizando corpos de prova com forma de "osso de cachorro" ou dog bone shaped (vide Figura 23a). Eles constituíam-se de duas partes principais: a parte central estreita e extremidades alargadas. Nas extremidades existiam regiões cilíndricas de $150 \mathrm{~mm}$ de diâmetro e $100 \mathrm{~mm}$ de altura. Estas regiões alargadas serviam para ancorarem de barras de aço para a finalidade de fixação na máquina de ensaios. Estas regiões de 
ancoragem faziam transição para a parte estreita do corpo de prova na forma de parábola cúbica de revolução. À meia altura se encontrava a parte mais estreita do elemento de concreto, cujo diâmetro era $68 \mathrm{~mm}$ (tal como a distância entre extremidades das barras do Anel J).

Para moldagem dos exemplares foram utilizadas fôrmas bipartidas fabricadas em poliuretano de alta densidade (vide Figura 23b). O procedimento de preparação das fôrmas para lançamento de concreto iniciava-se pela aplicação de agente desmoldante, seguido da vedação da base com filme plástico, do estaqueamento e travamento laterais com utilização de fita adesiva e, do posicionamento sobre base nivelada. O lançamento do concreto se dava pelo topo da fôrma, vertendo-se o concreto com utilização de concha, sem auxílio de vibração. Aproximadamente a cada terço do volume a ser lançado, aplicavam-se golpes com martelo de borracha a fim de evitar bolhas de ar aprisionadas na superfície interna das fôrmas. A desenforma de todos os corpos de prova foi realizada depois do primeiro dia de idade, seguida de cura ao ar por 28 dias.

a)

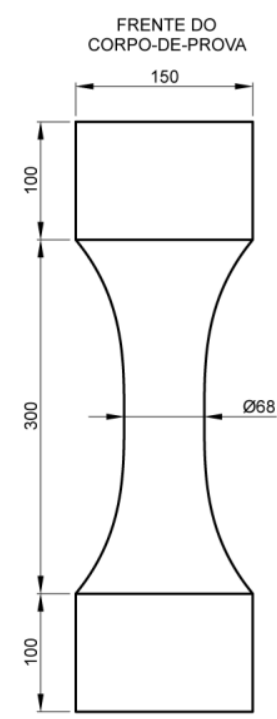

b)

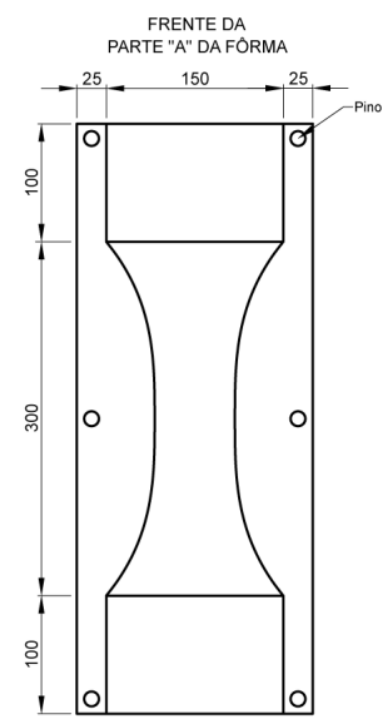

c)

LATERAL DA FORMA - PARTES A/B

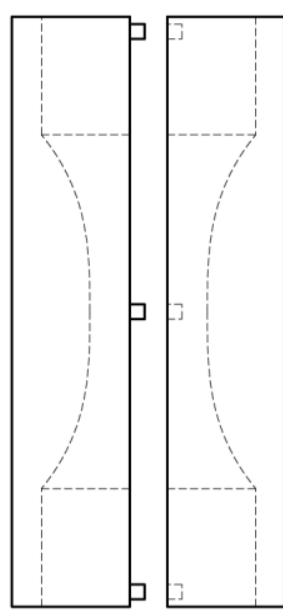

d)

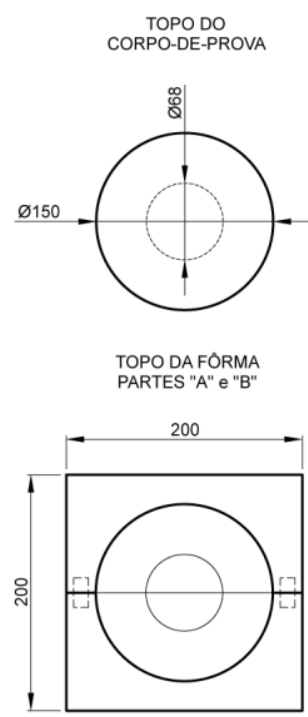

Figura 23 - llustração: a) do corpo de prova do tipo dog bone shaped; b) das partes da fôrma bipartida; c) das partes A/B da fôrma bipartida

Para fixar as barras de ancoragem nos corpos de prova, tornou-se necessária sua preparação prévia com execução de furo e colagem de barra de aço. A preparação incluía o corte de segmentos de barras de aço CA-50 de comprimento $200 \mathrm{~mm}$ e diâmetro $10 \mathrm{~mm}$, retificação de topo e base dos corpos 
de prova, marcação de centro para execução de furo, execução de furo com auxílio de furadeira de bancada ao longo de $100 \mathrm{~mm}$ de profundidade e, colagem das barras de aço com utilização de cola epóxi (vide Figura 24). Os furos foram executados em dois passos: primeiro utilizava-se broca diamantada de $8 \mathrm{~mm}$, depois se alargava o mesmo com utilização de broca de $12 \mathrm{~mm}$. Por fim o limpava-se o furo com aspersão de ar para colagem das barras de aço.

a) b)

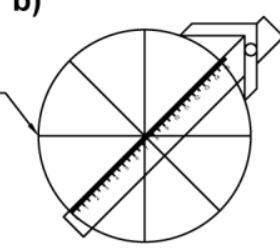

c)

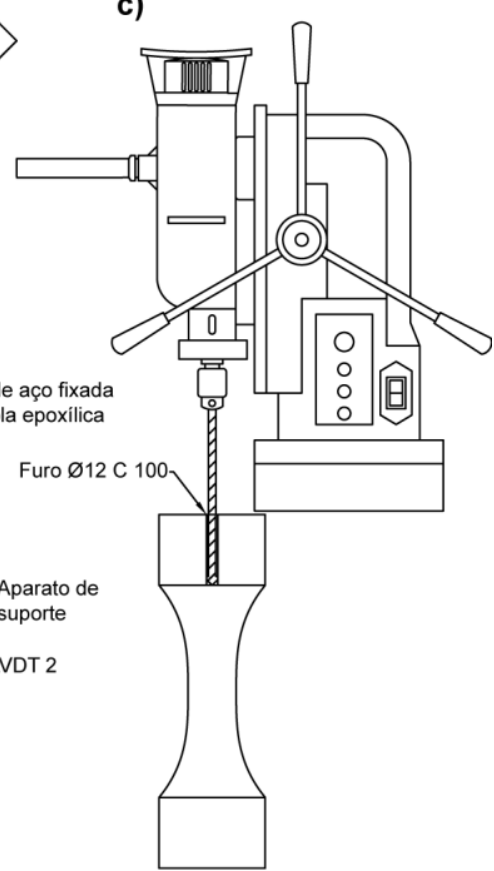

d)

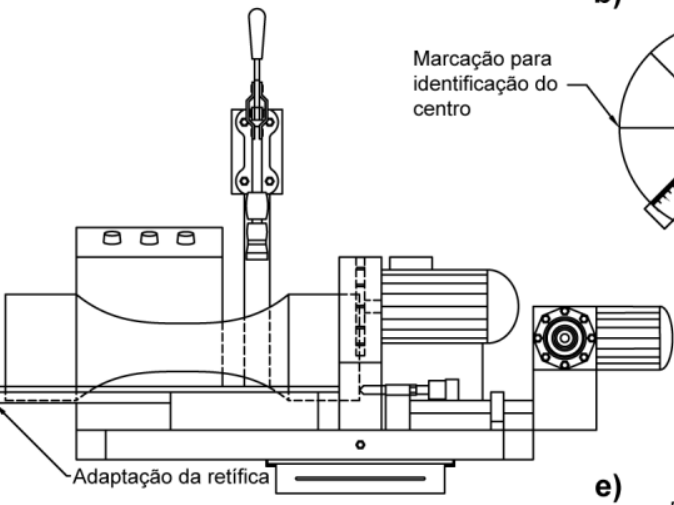

e)
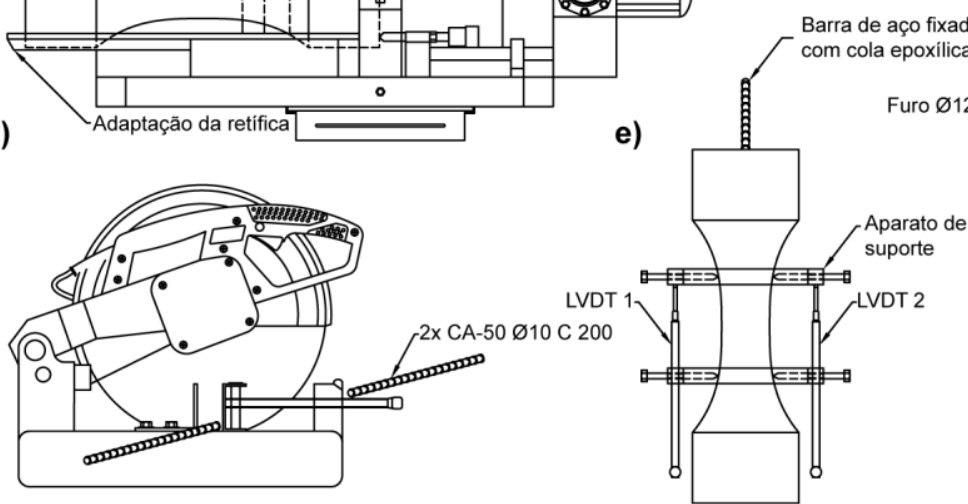

Figura 24 - Ilustração: a) da máquina retífica adaptada; b) da marcação de centro; c) da perfuração; d) do corte das barras de aço; e) da montagem do aparato para ensaio

Todos os ensaios de tração direta foram realizados na idade de 28 dias e com pelo menos um dia de cura para a cola epóxi Sikadur ${ }^{\circledR}$ 32. A montagem do ensaio se iniciava pelo posicionamento do aparato de suporte para um par de LVDTs HBM de $50 \mathrm{~mm}$ no corpo de prova. Seus pinos foram posicionados distantes $140 \mathrm{~mm}$ e equidistantes do centro dos exemplares, abrangendo a seção central de menor diâmetro do "pescoço" dos corpos de prova. Com a máquina de ensaios ligada, posicionava-se o corpo de prova sobre a garra inferior e aplicava-se pressão para fechá-la. Antes de prosseguir com fechamento da garra superior, a carga lida na máquina de ensaios era imposta à zero e observava-se a coincidência das nervuras das barras de aço com as ranhuras das garras de fixação, evitando-se assim efeitos de torção. As possíveis cargas de tração ou compressão promovidas no processo de 
mordedura das barras foram retornadas para o zero por controle de força. Depois de travado o crosshead da máquina de ensaios, iniciava-se o procedimento de ensaio por controle de deslocamento. Durante os ensaios, o atuador hidráulico progredia com velocidade de deslocamento de 0,1 $\mathrm{mm} / \mathrm{min}$ e os seguintes dados foram aquisitados com frequência de $5 \mathrm{~Hz}$ (vide Tabela 6): carga, deslocamento do atuador, tempo, deslocamento do LVDT 1 e deslocamento do LVDT 2. A máquina de ensaios utilizada foi a máquina de ensaios universal MTS modelo 311, com carga máxima de $1200 \mathrm{kN}$. Ao final de cada ensaio, observou-se o número de fibras presentes na seção fissurada.

Tabela 6 - Parâmetros do ensaio de tração direta

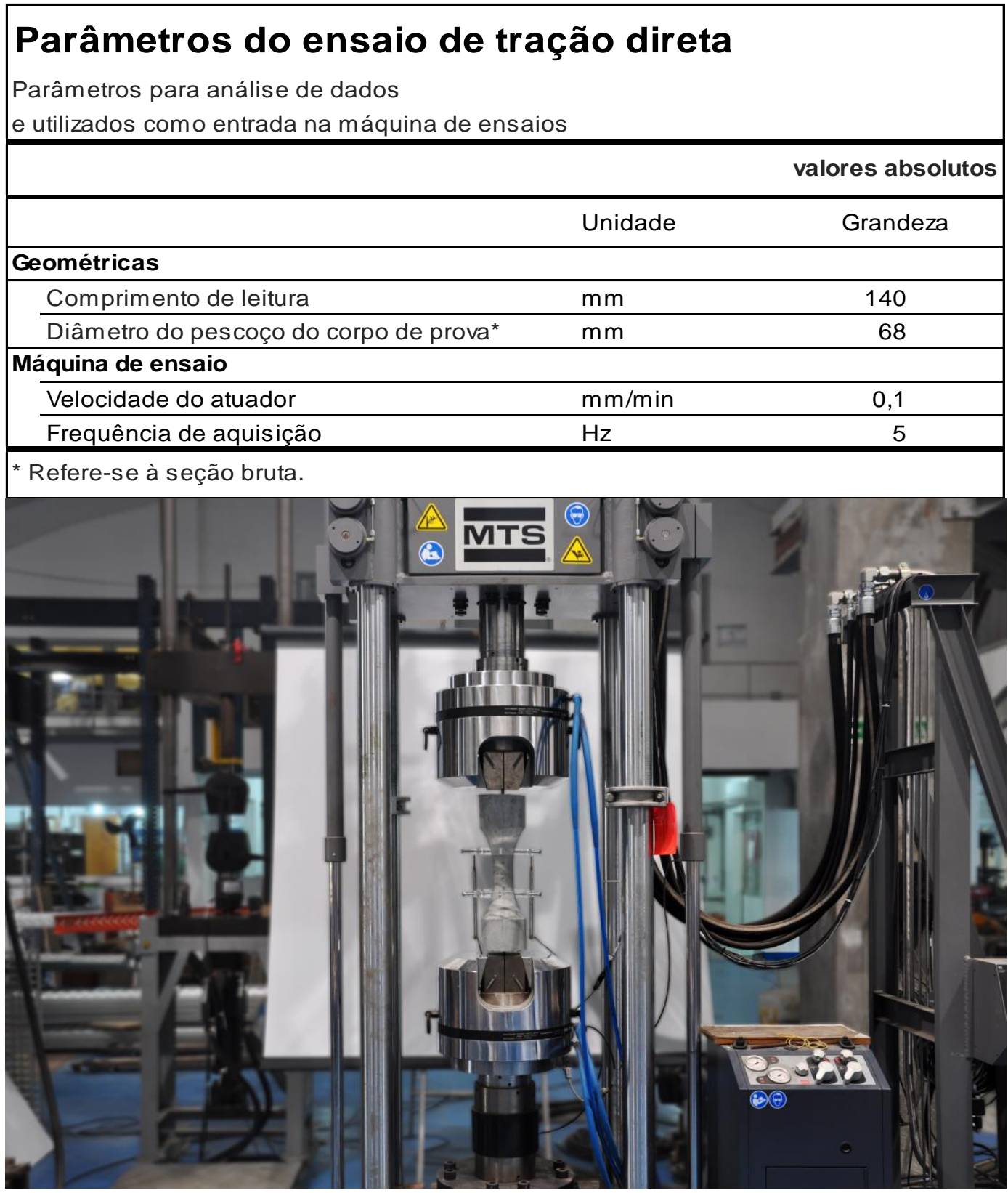

Figura 25 - Máquina de ensaios e aparato utilizados nos ensaios de tração direta 


\subsubsection{4 \\ Ensaio de flexão em prismas de concreto}

Os ensaios de flexão foram realizados em quatro pontos e com base na ASTM C1018 [93] utilizando-se prismas de concreto com dimensões de $150 \times 150 \times 750 \mathrm{~mm}$. Todos os corpos de prova foram moldados com auxílio de forma metálica posicionadas sobre base nivelada. Posteriormente aplicava-se desmoldante nas formas e o concreto era lançado pelo topo da fôrma com auxílio de concha, alternando-se as posições e sem uso de vibração. Aproximadamente a cada terço do volume a ser lançado, aplicavam-se golpes com martelo de borracha, a fim de evitar bolhas de ar aprisionadas nas superfícies internas das fôrmas. A desenforma de todos os corpos de prova foi realizada depois do primeiro dia de idade, seguida de cura ao ar por 28 dias. Os ensaios de flexão precediam de marcação de pontos de interesse com auxílio de lápis, régua e esquadro (vide Figura 26).

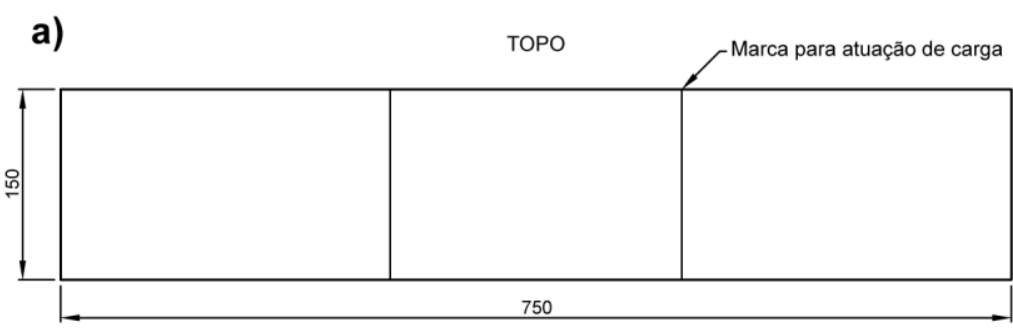

b)

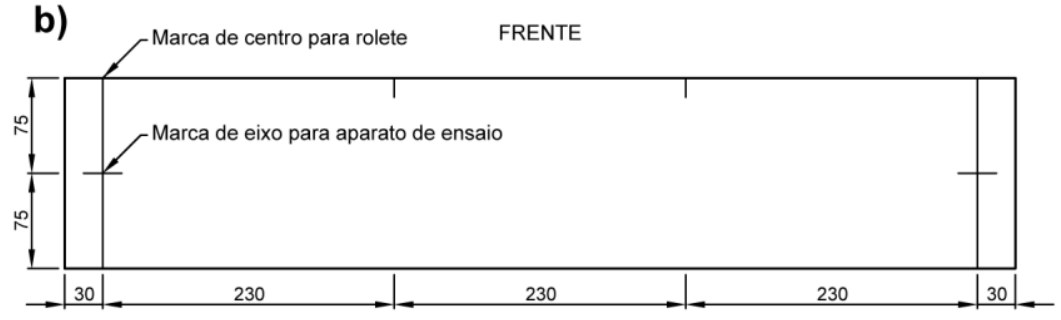

c) SEÇÃ̄o

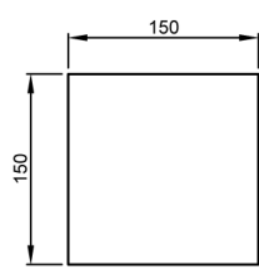

Figura 26 - Detalhe do corpo de prova prismático e das marcações efetuadas.

A montagem dos ensaios de flexão em quatro pontos se iniciava com alinhamento da base, do posicionamento dos roletes de apoio e do ajuste da distância entre eixos. Os roletes de apoio distavam $690 \mathrm{~mm}$ entre si e $30 \mathrm{~mm}$ das bordas dos corpos de prova. Os roletes de aplicação de carga, por sua vez, distavam $230 \mathrm{~mm}$, e posicionavam-se no terço médio dos corpos de prova. Tanto os roletes de aplicação de carga quanto os roletes de apoio possuíam liberdade de movimento horizontal. A preparação para ensaio precedia de posicionamento do aparato de suporte para LVDTs sobre o corpo de prova, bem como da fixação de chapa ao topo do corpo de prova que servia de obstáculo 
para aquisição externa das deflexões. Por fim, se conectava um par de LVDTs HBM de $20 \mathrm{~mm}$ ao dispositivo de aquisição de dados HBM QuantumX MX440B, antes de se iniciar o procedimento de ensaio (vide Figura 27 e Figura 28).

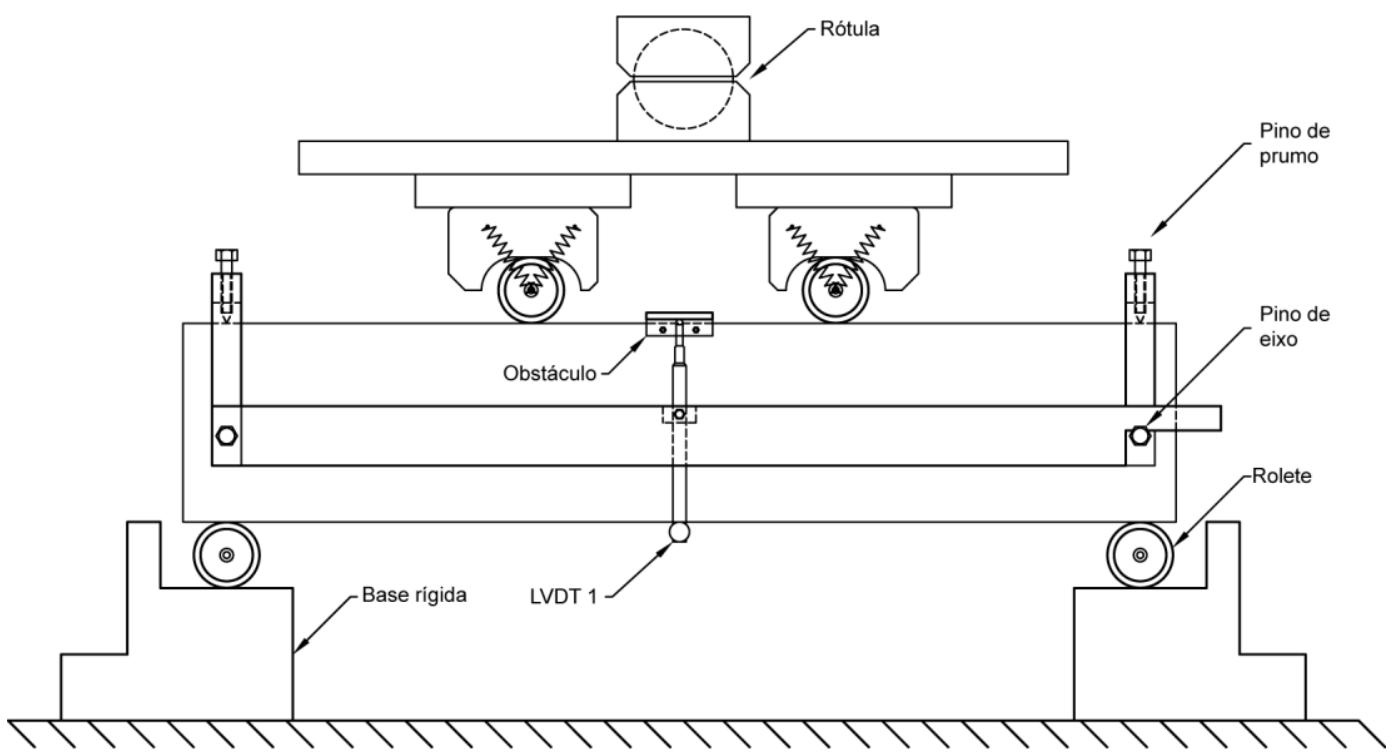

Figura 27 - Detalhe da montagem do ensaio de flexão em quatro pontos

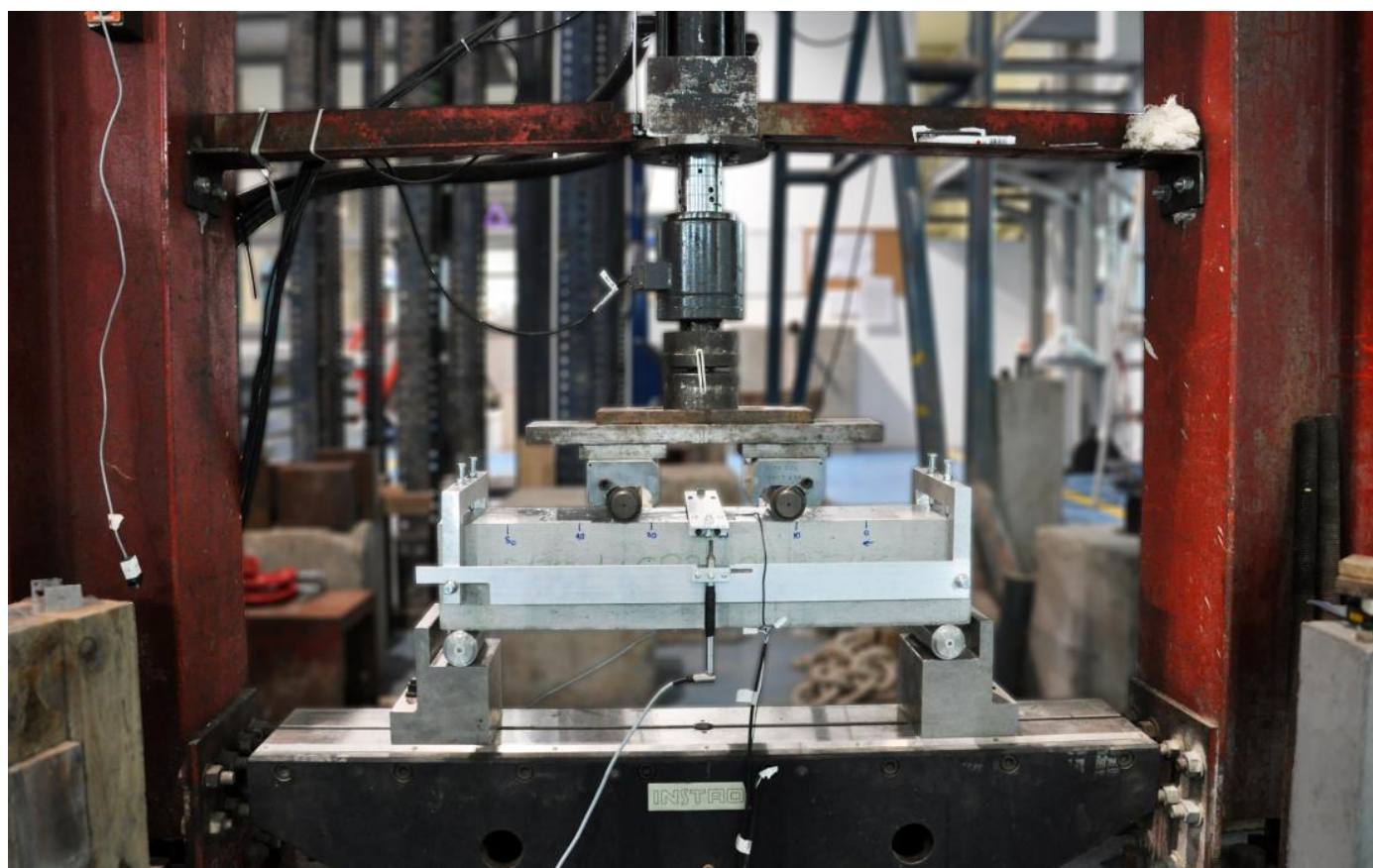

Figura 28 - Detalhe do pórtico rígido utilizado nos ensaios de flexão de corpos de prova prismáticos

A máquina de ensaios utilizada nos ensaios de flexão consistia em um atuador hidráulico com capacidade de $100 \mathrm{kN}$ montado sobre um pórtico rígido e controlado por uma estação central da MTS. Durante o ensaio, o atuador 
hidráulico progredia com velocidade de deslocamento de $0,2 \mathrm{~mm} / \mathrm{min}$ e os dados foram aquisitados com frequência de $5 \mathrm{~Hz}$ (vide Tabela 7).

Tabela 7 - Parâmetros do ensaio de flexão em corpos de prova prismáticos

\begin{tabular}{|c|c|c|}
\hline \multicolumn{3}{|c|}{$\begin{array}{l}\text { Parâmetros para análise de dados } \\
\text { e utilizados como entrada na máquina de ensaios }\end{array}$} \\
\hline & & valores absolutos \\
\hline & Unidade & Grandeza \\
\hline \multicolumn{3}{|l|}{ Geométricas } \\
\hline Base do corpo de prova* & $\mathrm{mm}$ & 150 \\
\hline Altura do corpo de prova* & $\mathrm{mm}$ & 150 \\
\hline Comprimento do corpo de prova* & $\mathrm{mm}$ & 750 \\
\hline \multicolumn{3}{|l|}{ Máquina de ensaio } \\
\hline Velocidade do atuador & $\mathrm{mm} / \mathrm{min}$ & 0,2 \\
\hline Frequência de aquisição & $\mathrm{Hz}$ & 5 \\
\hline
\end{tabular}

\subsection{2}

\section{Ensaios semiestruturais}

\subsubsection{1}

\section{Ensaios de flexão em painéis circulares}

Os ensaios de flexão de painéis circulares foram realizados com aplicação de carga no centro. Todos os painéis possuíam dimensões médias de $\phi 800 x$ $80 \mathrm{~mm}$ e foram moldados com auxílio de fôrma construída com base de madeira envolta de anel metálico. Antes da concretagem, posicionavam-se as fôrmas sobre base nivelada e aplicava-se agente desmoldante. O lançamento do concreto era feito diretamente sobre a fôrma, vertendo-se o concreto com auxílio de carrinho de mão, variando-se os pontos de lançamento diametralmente.

As desenformas dos corpos de prova foram realizadas após $24 \mathrm{~h}$, que seguiam de cura ao ar por 28 dias. Antes de cada ensaio, foram executadas marcações auxiliares, em ambas as faces dos painéis circulares. $\mathrm{Na}$ face superior, marcava-se o centro para orientar o ponto de atuação de carga e, na face inferior, marcava-se o centro para orientar a instrumentação. Objetivando-se medir a abertura de fissuras que surgiam na parte inferior central dos painéis circulares em direção às regiões entre apoios, foram fixados à sua base três transdutores de deslocamento potenciométricos Gefram de $50 \mathrm{~mm}$ com auxílio 
de cola epóxi Araldite ${ }^{\circledR}$. Os três transdutores formavam entre si um arranjo triangular de lado $120 \mathrm{~mm}$ e centroide coincidente com o disco (vide Figura $29 \mathrm{e}$ Figura 30).

a)

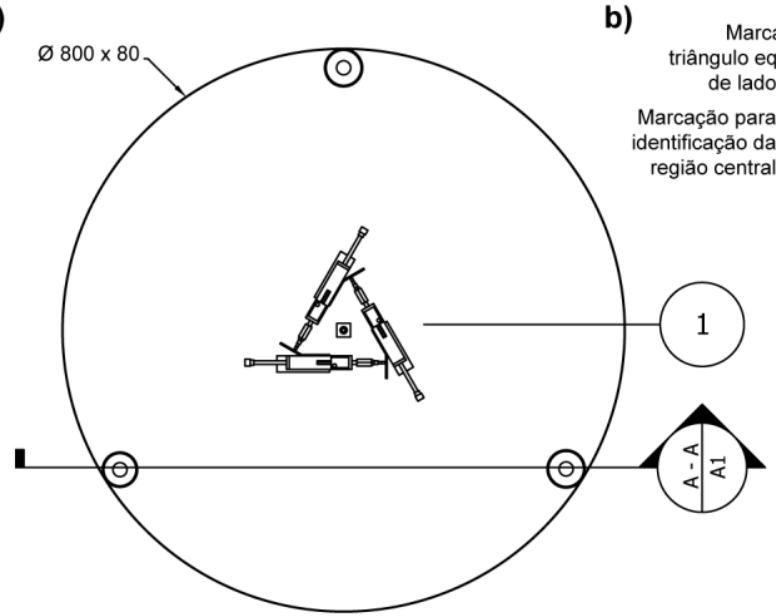

b) Marcaçăo de Marcaçăo do

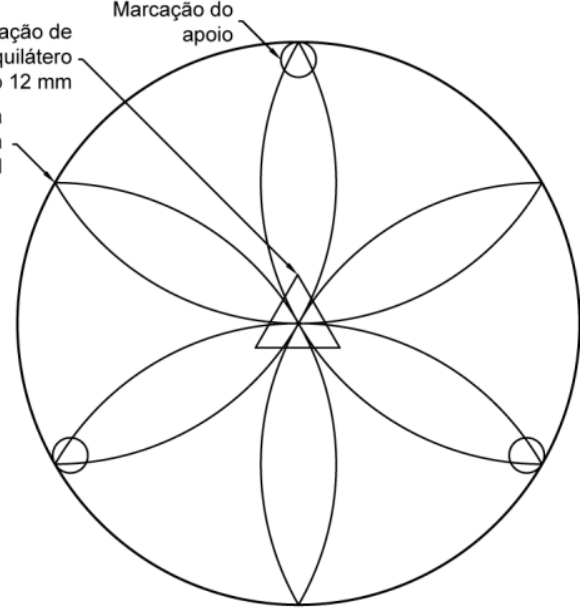

Figura 29 - llustração: a) do painel circular com LVDTs e pontos de apoio colados; b) das marcações de pontos chave

Depois da realização da marcação dos pontos de interesse com auxílio de lápis, régua e esquadro, seguia-se da fixação dos apoios no próprio disco utilizando-se fita adesiva emborrachada de dupla face $3 \mathrm{M}^{\circledR}$. A montagem do ensaio se iniciava com o posicionamento dos suportes de apoio que consistiam em três apoios de alumínio $\phi 50 \mathrm{~mm}$, unidos por barras rosqueadas e providos de esfera rotulada, formando um arranjo triangular equilátero com arestas de $65 \mathrm{~cm}$, aproximadamente (vide Figura 30). Por fim, transportavam-se os painéis circulares até a máquina de ensaios com auxílio de empilhadeira mecânica, posicionava-se um transdutor na parte inferior do disco para medição da deflexão central e fixava-se o pistão de raio 800 mm (vide Figura 31).

a)

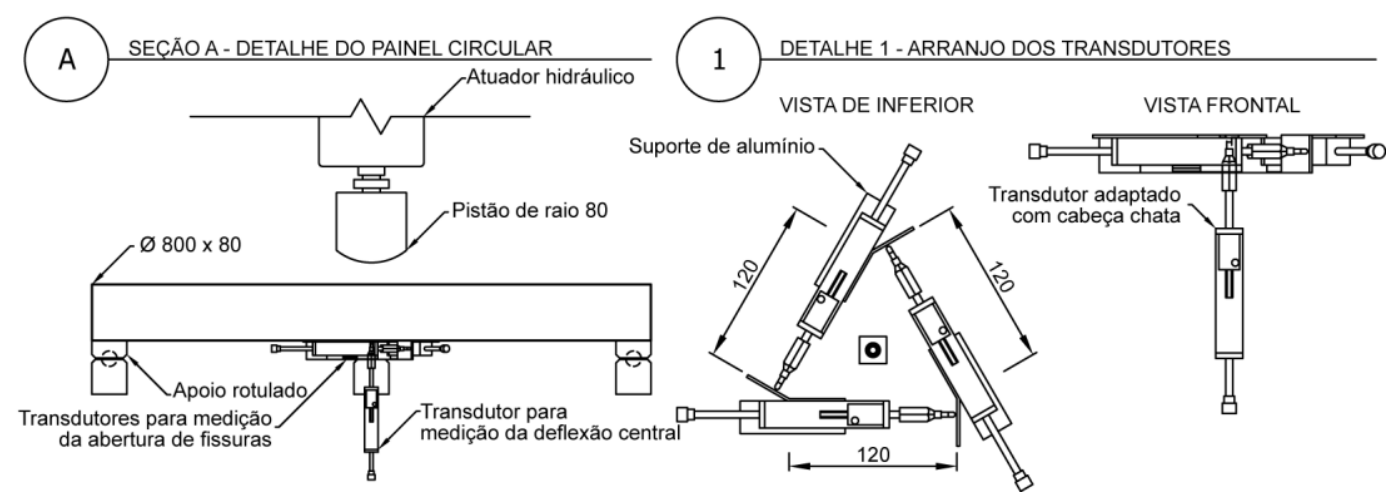

Figura 30 - llustração: a-b) detalhes da disposição dos transdutores 
A máquina de ensaios utilizada nos ensaios de flexão consistia em um atuador hidráulico de capacidade 500 kN fixado a um pórtico rígido e controlado por uma estação central da MTS. Durante os ensaios, o atuador hidráulico progredia com velocidade de deslocamento de $2 \mathrm{~mm} / \mathrm{min}$ e os seguintes dados foram aquisitados com frequência de $5 \mathrm{~Hz}$ : carga, deslocamento do atuador e tempo (vide Tabela 8). Por fim, se conectavam os transdutores potenciométricos Gefram ao dispositivo de aquisição de dados HBM QuantumX MX1615, antes de se iniciar o procedimento de ensaio (vide Figura 31).

Tabela 8 - Parâmetros do ensaio de flexão em painéis circulares

\begin{tabular}{|c|c|c|}
\hline \multicolumn{3}{|c|}{$\begin{array}{l}\text { Parâmetros para análise de dados } \\
\text { e utilizados como entrada na máquina de ensaios }\end{array}$} \\
\hline & & valores absolutos \\
\hline & Unidade & Grandeza \\
\hline \multicolumn{3}{|l|}{ Geométricas } \\
\hline Diâmetro do corpo de prova* & $\mathrm{mm}$ & 800 \\
\hline Altura do corpo de prova* & $\mathrm{mm}$ & 80 \\
\hline \multicolumn{3}{|l|}{\begin{tabular}{|l|} 
Máquina de ensaio \\
\end{tabular}} \\
\hline Velocidade do atuador & $\mathrm{mm} / \mathrm{min}$ & 2 \\
\hline Frequência de aquisição & $\mathrm{Hz}$ & 5 \\
\hline
\end{tabular}

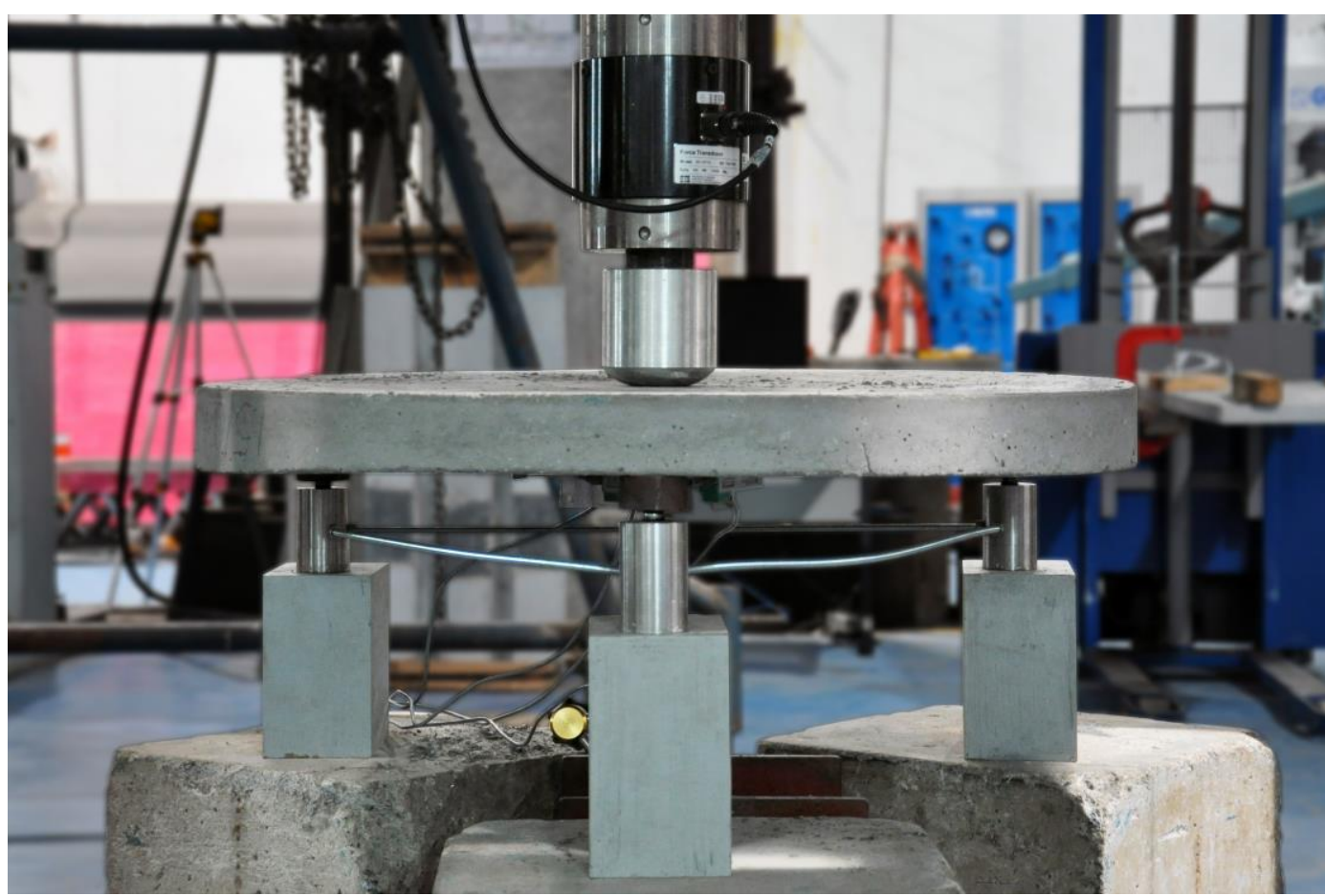

Figura 31 - Detalhe de um painel circular posicionado na máquina de ensaios 


\subsection{3}

\section{Ensaios estruturais}

\subsubsection{1}

\section{Ensaios em vigas curtas armadas}

Os ensaios de flexão foram realizados com aplicação de carga em dois pontos, dentro do terço médio das vigas de concreto armado. Cada elemento de viga possuía dimensões de $150 \times 150 \times 1200$ mm e um entalhe na seção central. Este entalhe possuía altura coincidente com o cobrimento nominal de armaduras e era formado por meio da fixação de uma cantoneira de alumínio na base das fôrmas. A região dos apoios era armada ao cortante com estribos $\phi 5,0 \mathrm{~mm}$ a cada $150 \mathrm{~mm}$, excetuando-se o vão central. Cada uma das barras de aço que compôs as armaduras longitudinais foram instrumentadas com três strain gages EXCEL de $6 \mathrm{~mm}$ de comprimento e $120 \Omega$, cada um distando $100 \mathrm{~mm}$ entre si (vide Figura 32).

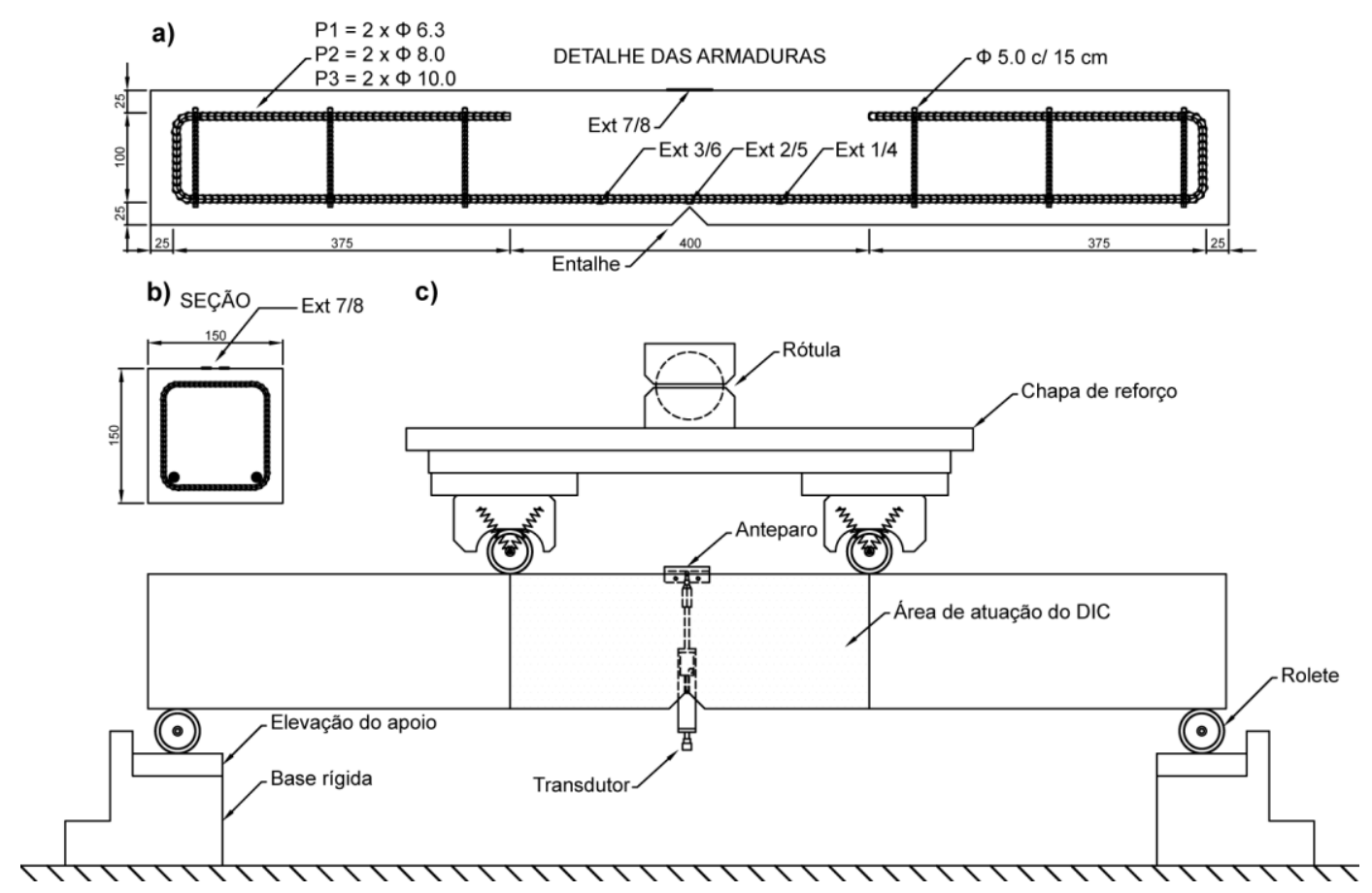

Figura 32 - Detalhe das armaduras e de montagem dos ensaios de flexão em vigas armadas

Para investigar a falha dos elementos formados a partir de SCC e de SFRSCC, foram fabricadas seis séries de vigas curtas armadas de $0,15 \times 0,15 \times 1,2 \mathrm{~m}$, onde cada série foi representada por uma viga de concreto armado. Para cada uma das três configurações de armaduras foi fabricada uma 
viga com SCC e outra com SFRSCC. Cada par de vigas foi armada com pares de barras de aço longitudinais nas configurações $2 \phi 6,3,2$, 8,0 e $2 \phi 10,0$, que correspondem às taxas geométricas de armadura 0,28, 0,45 e 0,70\%, respectivamente.

As fôrmas utilizadas para concretagem das vigas foram fabricadas em compensado naval de $30 \mathrm{~mm}$ e dotavam de travamentos laterais. Todas elas passaram por inspeção dimensional antes de cada concretagem, resultando em elementos com variação de $\pm 2 \mathrm{~mm}$ em suas dimensões. Antes da concretagem posicionavam-se as fôrmas sobre base nivelada e aplicava-se agente desmoldante para madeira. O lançamento do concreto era feito diretamente sobre a fôrma com auxílio de concha metálica, variando-se os pontos de lançamento. A cada terço do volume de concreto lançado, aplicavam-se golpes com martelo de borracha sobre a fôrma para evitar o aprisionamento de ar nas superfícies internas.

A desenforma de todas as vigas foram realizadas depois do primeiro dia de idade, seguindo de cura com manta úmida por 28 dias. Os ensaios de flexão precederam da marcação dos pontos de interesse com auxílio de lápis, régua e esquadro para posicionamento das vigas na máquina de ensaios e fixação de um par de extensômetros elétricos no topo das vigas. Para finalidade de monitoramento por correlação digital de imagens, executou-se ainda uma pintura de fundo branco fosco na face frontal da viga, com sobreposição de borrifo esparso de cor preta (vide Figura 34).

A montagem do ensaio de flexão em quatro pontos se iniciava com alinhamento da base, do posicionamento dos roletes de apoio e do ajuste da distância entre eixos. Os roletes de apoio distavam a $110 \mathrm{~cm}$ entre si e $25 \mathrm{~mm}$ das bordas das vigas. Os roletes de aplicação de carga distavam $30 \mathrm{~cm}$, na região central dos elementos. Tanto os roletes de aplicação de carga quanto os roletes de apoio tinham liberdade de movimento horizontal. A preparação para início do ensaio seguia da fixação de uma chapa ao topo da viga, que servia de obstáculo para aquisição externa das deflexões por um transdutor potenciométrico Gefram de $50 \mathrm{~mm}$ que conectava-se ao dispositivo de aquisição de dados HBM QuantumX MX440B. Fixava-se, então, um par de strain gages de $50 \mathrm{~mm}$ de comprimento e resistência de $120 \Omega$ na região superior central das vigas com auxílio de cola epóxi $\operatorname{Araldite}^{\circledR}$, que por sua vez se conectavam ao 
DAQ HBM QuantumX MX1615, antes de se iniciar o procedimento de ensaio (vide Figura 33). Por fim, o sistema de correlação digital de imagens (DIC) era posicionado e calibrado com placa de $12 \times 9$ pontos espaçados de $12 \mathrm{~mm}$. Os parâmetros de entrada no sistema DIC foram a função de correlação NSSD (normalized sum of squared differences), a dimensão do subconjunto de 41 pixels, a dimensão do passo de 10 pixels e o tamanho das janelas de deformação em 15.

A máquina de ensaios utilizada neste ensaio consistia em um atuador hidráulico com capacidade $500 \mathrm{kN}$ fixado sobre um pórtico rígido e controlado por uma estação central da MTS. Durante os ensaios, o atuador hidráulico progredia com velocidade de deslocamento de $2 \mathrm{~mm} / \mathrm{min}$ e os dados foram aquisitados com frequência de $2 \mathrm{~Hz}$ (vide Tabela 9). O sistema de DIC monitorava os deslocamentos dentro de uma área de $30 \times 15 \mathrm{~cm}$ no vão central da viga e fazia fotografias com frequência de $2 \mathrm{~Hz}$. O equipamento era composto por um par de câmeras monocromáticas Point Grey GRAS-50S5M de 5MP (2248 × 2048 pixels) equipadas com lentes Tamron A031 AF28-200mm F/3.8-5.6 e fonte de luz de fibra ótica Olympus. O software de controle foi o VIC-3D DIC versão 2010 da Correlated Solution Inc.

\section{Tabela 9 - Parâmetros do ensaio de flexão em vigas armadas}

\section{Parâmetros do ensaio de flexão em vigas armadas \\ Parâmetros para análise de dados \\ e utilizados como entrada na máquina de ensaios}

\begin{tabular}{|llc|}
\hline & & valores absolutos \\
\hline Geométricas & Unidade & Grandeza \\
\hline Base do corpo de prova* & & 15 \\
\hline Altura do corpo de prova* & $\mathrm{cm}$ & 15 \\
\hline Comprimento do corpo de prova* & $\mathrm{cm}$ & 120 \\
\hline Máquina de ensaio & $\mathrm{cm}$ & 2 \\
\hline Velocidade do atuador & $\mathrm{mm} / \mathrm{min}$ & 2 \\
\hline Frequência de aquisição & $\mathrm{Hz}$ & \\
\hline * Refere-se às dimensões nominais (efetivas). & & \\
\hline
\end{tabular}




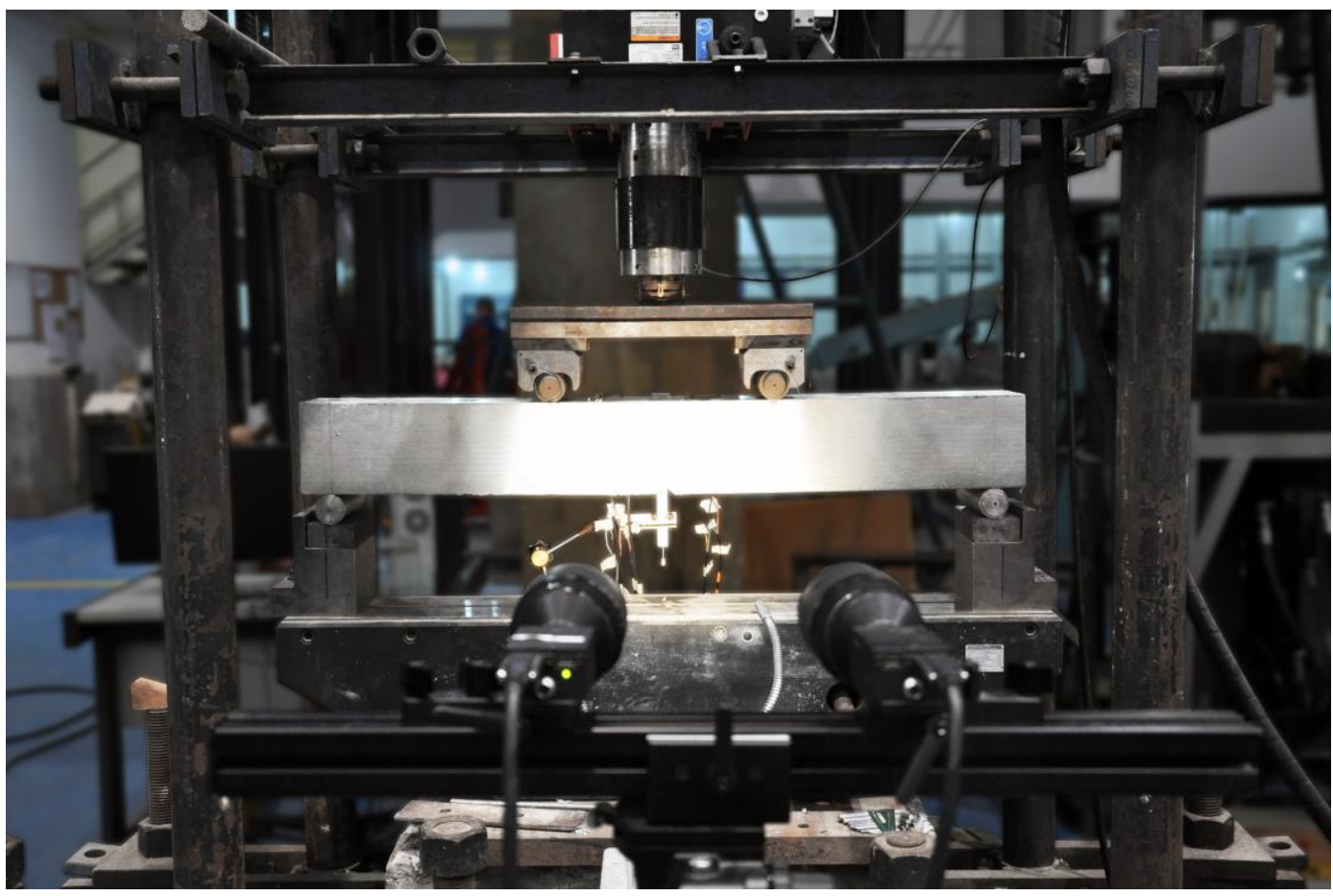

Figura 33 - Detalhe do pórtico rígido utilizado nos ensaios de flexão em vigas armadas

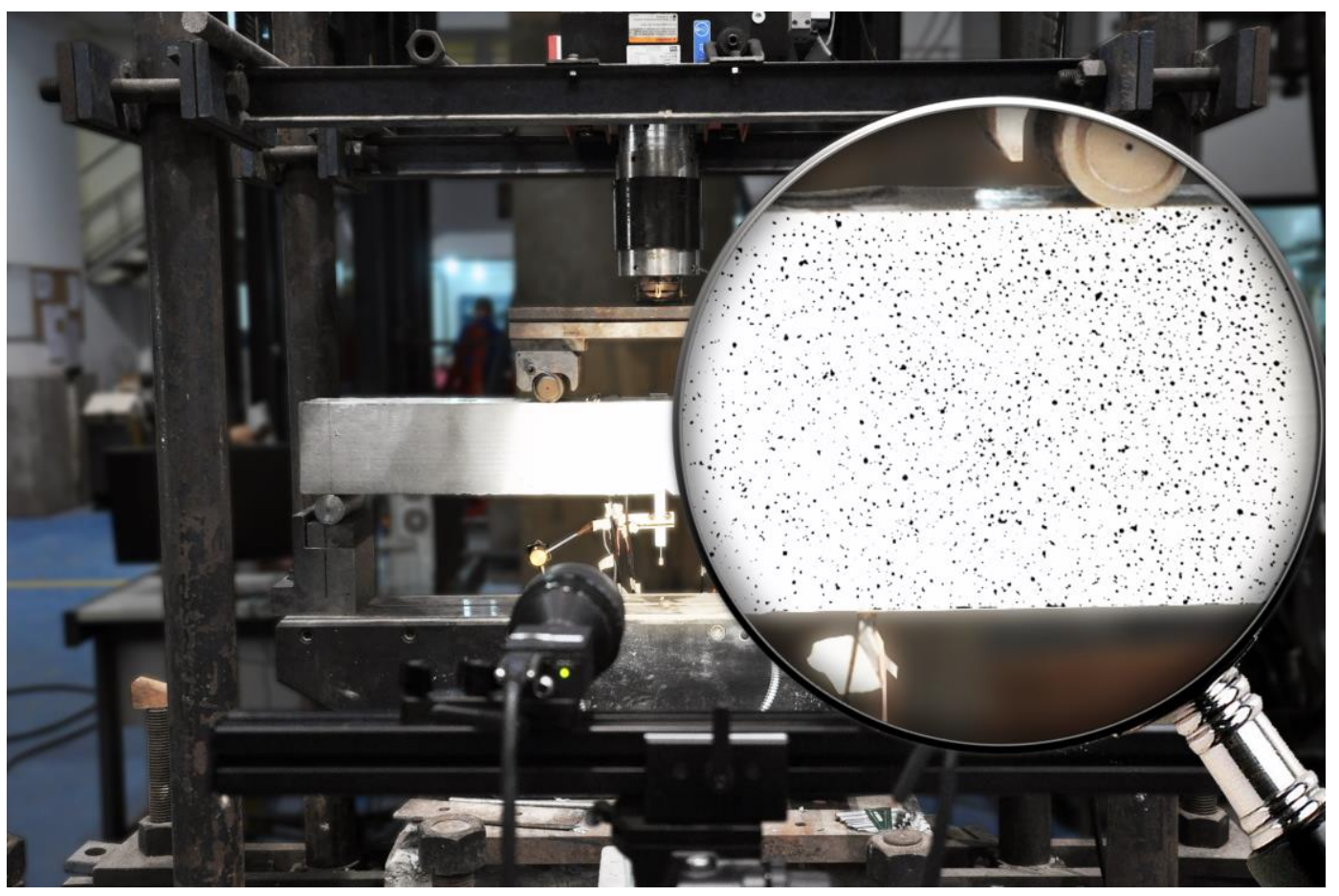

Figura 34 - Detalhe da pintura base para monitoramento por sistema de correlação digital de imagens (DIC). 


\section{4 \\ Resultados e análises}

Este capítulo se dedica à apresentação e discussão dos resultados dos ensaios mecânicos realizados nos corpos de prova concretados com a matriz de concreto autoadensável e com o concreto reforçado com fibras de aço. Compreende os ensaios de caracterização dos concretos por meio das determinações do espalhamento; da resistência à compressão axial; do módulo elástico à compressão; da resistência à tração direta e da resistência à flexão. Estas determinações objetivaram avaliar a influência do acréscimo do percentual volumétrico de fibras e o desempenho diferenciado dos concretos reforçados com os três tipos distintos de fibras de aço. Para auxiliar esta análise, foi determinada a tenacidade à flexão para todos os ensaios, sendo confrontados com o desempenho demonstrado nos ensaios de tenacidade à flexão em painéis circulares. Por fim, discutiu-se a capacidade de carga e o padrão de fissuras observado nos ensaios de flexão em vigas curtas armadas.

\section{1 Ensaios na escala do material}

\subsection{1}

\section{Determinação do espalhamento e do tempo de escoamento}

A avaliação da reologia das misturas no estado fresco foi realizada por meio do ensaio de espalhamento, cujo desempenho dos concretos foi relacionado com os valores de espalhamento e com os tempos de escoamento. Para todas as dez séries ensaiadas utilizou-se como referência o valor médio de espalhamento de $650 \mathrm{~mm}$ recomendado pela norma $\mathrm{ACl} 237 \mathrm{R}$ [111] e que corresponde à classe "SF2" da NBR 15823-1 [112]. Para cada uma das séries realizou-se uma única determinação, mantendo-se constante o teor de aditivo superplastificante em 6,0\%, cujos resultados podem ser observados na Figura 35 e Tabela 10. 

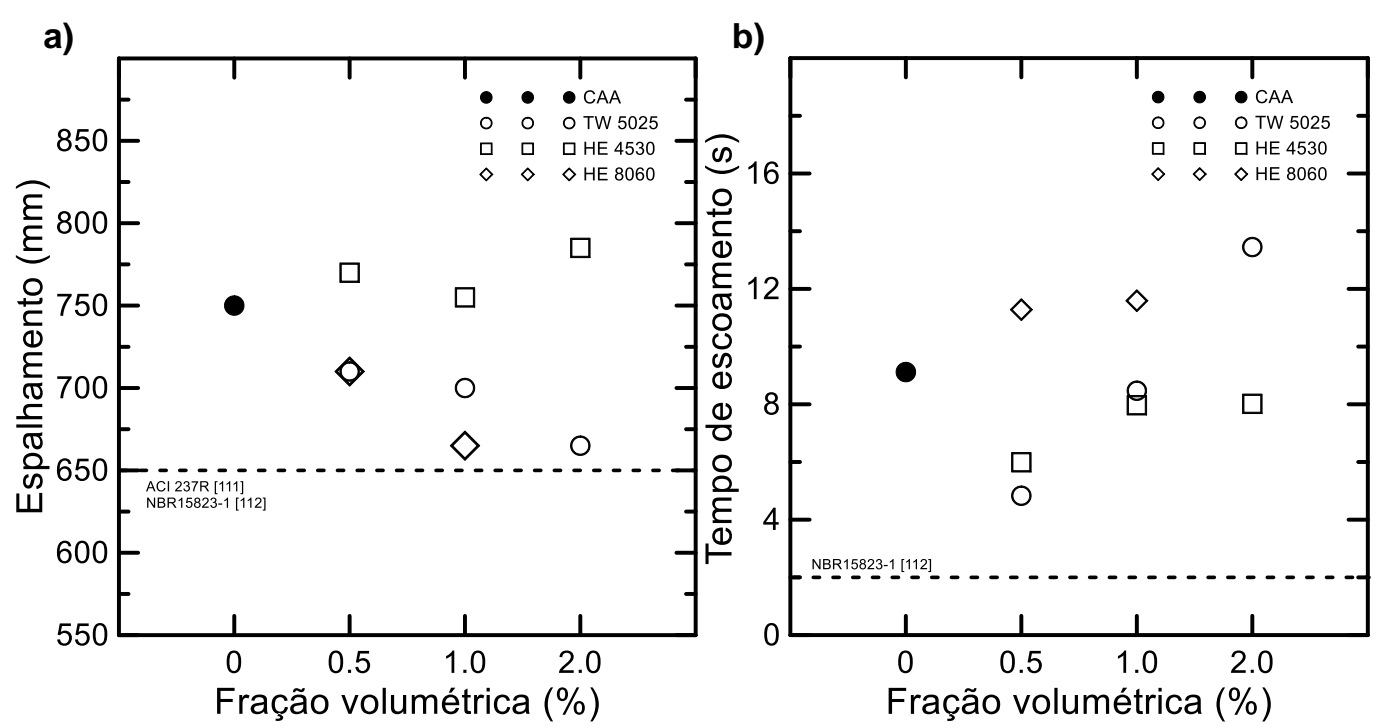

Figura 35 - Gráfico: a) comparativo dos espalhamentos em função da frações volumétricas de fibras; b) comparativo dos tempos de escoamento em função das frações volumétricas de fibras

Tabela 10 - Resumo dos resultados dos ensaios de espalhamento modificado

\section{Resultados do ensaio de espalhamento modificado \\ Resultados do ensaio de espalhamento utilizando cone de Abrams invertido}

\begin{tabular}{|lcc|}
\hline \multicolumn{3}{|c|}{ valores arredondados ao múltiplo ou à significância mais próxima } \\
\hline Referência / Família & $\begin{array}{c}\text { Espalhamento } \\
\mathrm{mm}\end{array}$ & $\begin{array}{c}T_{500} \\
\mathrm{~s}\end{array}$ \\
\hline CAA - 0\% & 750 & $09: 07$ \\
\hline TW 5025 - 0.5\% & 710 & $04: 50$ \\
\hline HE 4530- 0.5\% & 770 & $05: 59$ \\
\hline HE 8060 - 0.5\% & 710 & $11: 17$ \\
\hline TW 5025 - 1\% & 700 & $08: 28$ \\
\hline HE 4530 - 1\% & 755 & $07: 58$ \\
\hline HE 8060 - 1\% & 665 & $11: 35$ \\
\hline TW 5025 - 2\% & 665 & $13: 27$ \\
\hline HE 4530 - 2\% & 785 & $08: 01$ \\
\hline HE 8060 - 2\%* & - & - \\
\hline${ }^{*}$ Indeterminável com o tronco cônico invertido. & \\
\hline
\end{tabular}

Pela análise dos resultados da Tabela 10, observa-se que o melhor desempenho não foi atribuído ao concreto de referência, mas ao concreto reforçado com fibras providas de ganchos de razão de aspecto 45 . Nestes concretos, o efeito do acréscimo de massa promovido pela substituição volumétrica de fibras contribuiu positivamente nos valores de espalhamento e na redução dos tempos de escoamento (vide Figura 36). 
a)

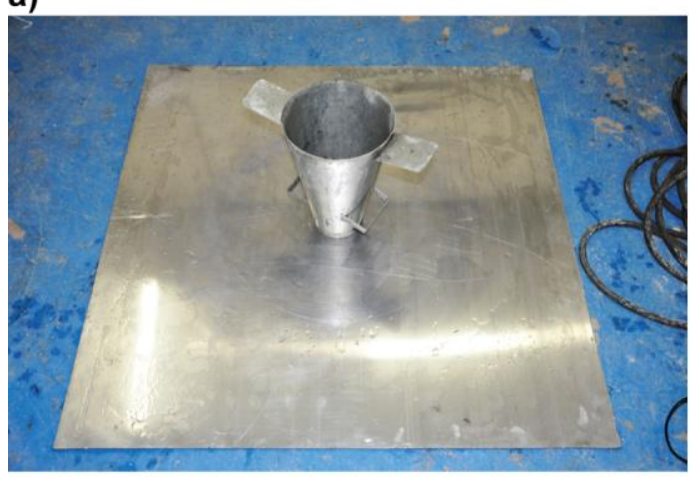

c)

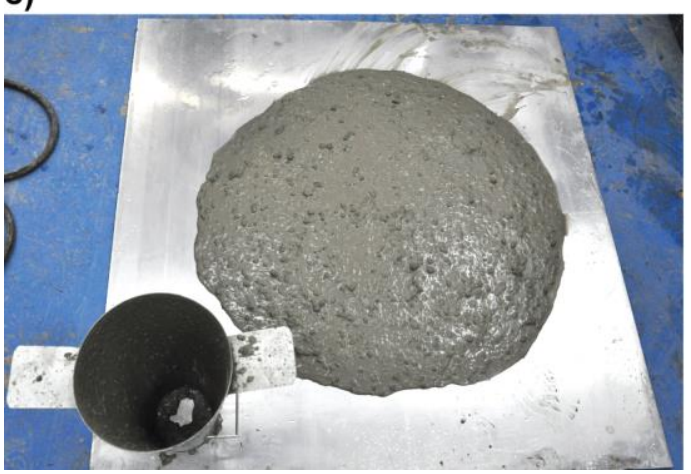

b)

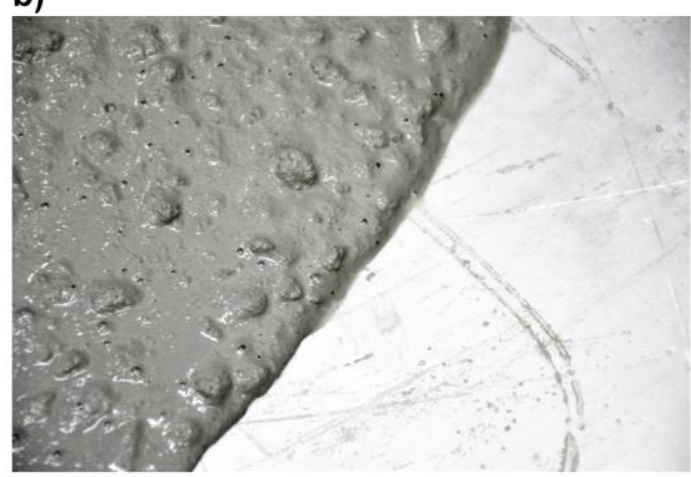

d)

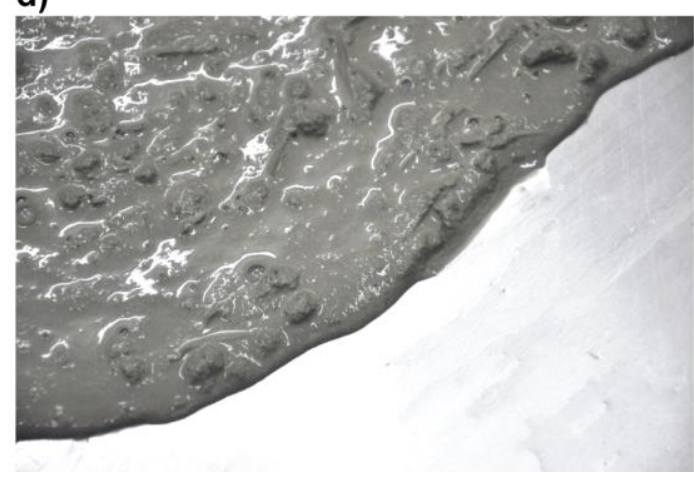

Figura 36 - Fotografia: a) da placa base e do cone de Abrams na posição invertida; b) da borda da matriz de concreto autoadensável; c) do concreto reforçado com a fração volumétrica de $0,5 \%$ de fibras com ganchos de $30 \mathrm{~mm}$ e razão de aspecto 45; d) da borda do autoadensável reforçado com fibras de aço.

O desempenho global dos concretos reforçados com fibras torcidas nos ensaios de espalhamento foi sempre inferior àqueles observados nos concretos reforçados com fibras com ganchos nas extremidades. Este efeito negativo pode ser associado à influência da geometria das fibras torcidas, trazendo prejuízo tanto nos valores de espalhamento, quanto nos tempos de escoamento. $\mathrm{Na}$ fração volumétrica de $0,5 \%$, o espalhamento dos concretos reforçados com fibras torcidas foi semelhante ao daqueles reforçados com fibras com ganchos de razão de aspecto 80 , diferenciando-se pelo tempo de escoamento, que foi sempre superior. Para a fração volumétrica de $1,0 \%$, os concretos reforçados com fibras torcidas apresentaram heterogeneidade, traduzida por uma pequena aglomeração na região central da placa base, enquanto que para a fração de 2,0 \%, houve aglomeração considerável em toda a região circunferencial (vide Figura 37a e Figura 37b). 
a)

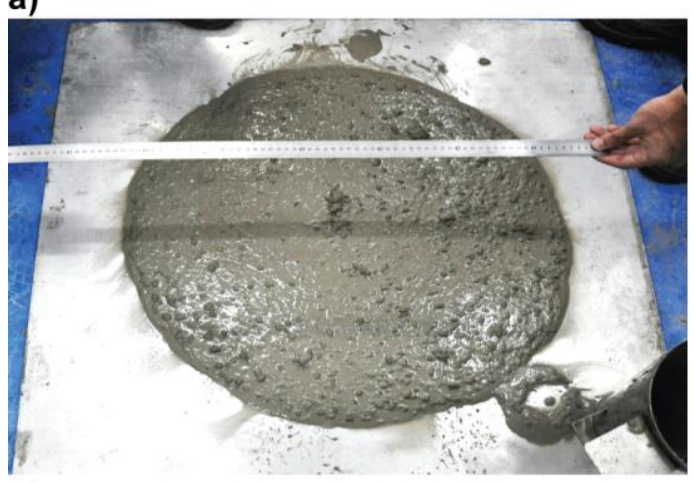

c)

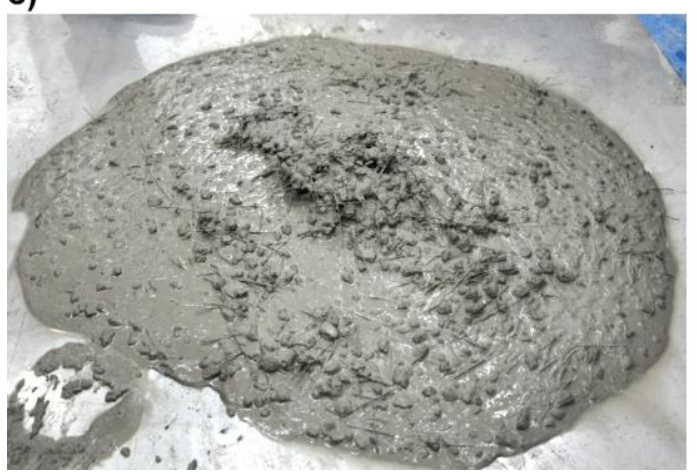

b)

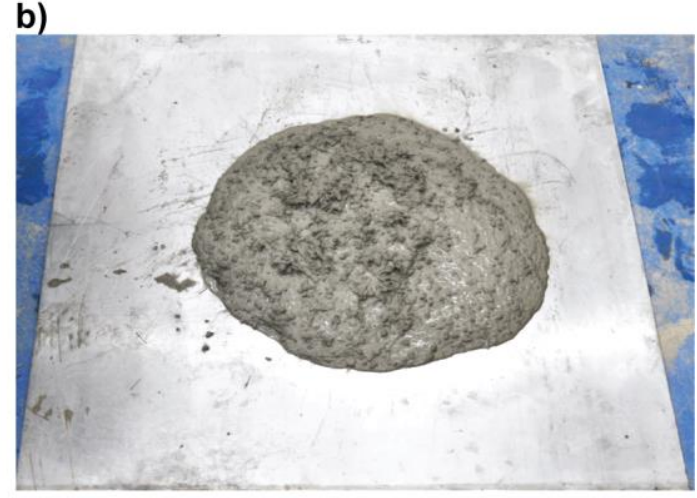

d)

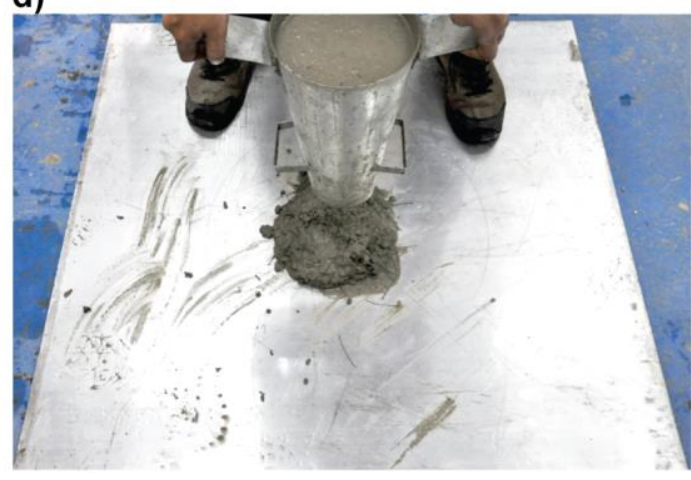

Figura 37 - Fotografia: a) do concreto autoadensável reforçado com a fração volumétrica de $1,0 \%$ de fibras torcidas de comprimento $25 \mathrm{~mm}$ e razão de aspecto 50; b) do concreto autoadensável reforçado com a fração volumétrica de $2,0 \%$ de fibras torcidas de comprimento $25 \mathrm{~mm}$ e razão de aspecto 50 ; c) do concreto com a fração volumétrica de $1,0 \%$ de fibras com ganchos de comprimento $60 \mathrm{~mm}$ e razão de aspecto 80 ; d) do concreto reforçado com fibras com as fibras de "c", mas com a fração volumétrica de $2,0 \%$

Os SFRSCCs que continham fibras de aço com ganchos nas extremidades e comprimento de $60 \mathrm{~mm}$ apresentaram resultados de espalhamento muito semelhantes aos que continham fibras torcidas de $25 \mathrm{~mm}$, para a fração de $0,5 \%$, excetuando-se apenas pelo tempo de escoamento que foi duas vezes maior. Quando na fração volumétrica de 1,0 \%, houve aglomeração significativa de fibras na região central da placa de espalhamento (vide Figura 37c). Uma vez utilizada a fração volumétrica de $2,0 \%$, o concreto reforçado com fibras HE 80/60 apresentou segregação e pouca trabalhabilidade. Observou-se ainda que, na fração volumétrica de 2,0 \% houve obstrução do cone de Abrams na posição invertida e, uma vez com o cone na posição normal, o abatimento mostrou-se comparável ao de concretos simples (vide Figura 37d). Sabendo-se deste comportamento característico das famílias dos concretos reforçados com as fibras HE 80/60 nas frações volumétricas de 1,0 e 2,0\%, não foi possível 
atribuí-los a qualidade de concreto autoadensável, mas se decidiu realizar os demais ensaios para fins de comparação.

\subsection{2}

\section{Determinação da resistência e do módulo à compressão axial}

O concreto de referência utilizado neste estudo foi dosado inicialmente para alcançar a resistência característica à compressão axial de $80 \mathrm{MPa}$, porém Marangon [26] obteve a resistência média à compressão de 75,93 MPa. Rambo [32], por sua vez, utilizou esta mesma matriz, realizando os ajustes necessários para substituir as microfibras minerais por uma adição de pó de quartzo denominada de Sílica 325, resultando na resistência média de 64,61 MPa. No estudo presente utilizaram-se as mesmas considerações de Rambo [32] e obteve-se a resistência média à compressão axial de 73,0 MPa (vide Tabela 11). O módulo elástico estático à compressão, por sua vez, foi muito semelhante àqueles obtidos nos trabalhos anteriores supracitados.

Tabela 11 - Resumo dos resultados dos ensaios de resistência e módulo elástico à compressão axial do concreto de referência

\section{Resultados dos ensaios de compressão e módulo \\ Resultados dos ensaios de compressão axial do módulo elástico}

\begin{tabular}{|lcc|}
\hline & valores arredondados à significância mais próxima \\
\hline Indivíduo / corpo de prova & $f_{c}$ & $E^{*}$ \\
& $\mathrm{MPa}$ & $\mathrm{GPa}$ \\
\hline Resultados & & - \\
\hline CAA - 0\%, CP1 & 75,4 & - \\
\hline CAA - 0\%, CP2 & 67,1 & - \\
\hline CAA - 0\%, CP3 & 74,3 & - \\
\hline CAA - 0\%, CP5 & 80,1 & 35,4 \\
\hline CAA - 0\%, CP4 & 67,6 & 32,2 \\
\hline CAA - 0\%, CP6 & 73,4 & $\mathbf{3 3 , 8}$ \\
\hline MÉDIA & $\mathbf{7 3 , 0}$ & $\mathbf{2 , 3}$ \\
\hline DESVIO PADRÃO & $\mathbf{5 , 0}$ & $\mathbf{6 , 7}$ \\
\hline COEFCIENTE DE VARIAÇÃO (\%) & $\mathbf{6 , 8}$ \\
\hline * Refere-se ao módulo secante & & \\
\hline
\end{tabular}

Foi discutido na seção 2.4.7, que o incremento da resistência à compressão promovido pela adição de fibras de aço no concreto é pequeno quando utilizadas frações menores que 2,0 \%. Para confirmar este fato, avaliouse a influência da incorporação das fibras HE 4530 na matriz autoadensável, 
resultando-se no incremento de $12 \%$ na resistência à compressão axial, assim como observado por Marangon [26] (vide Tabela 12). O módulo elástico, por sua vez, não se mostrou afetado consideravelmente com a inclusão de fibras de aço.

Tabela 12 - Resumo dos resultados dos ensaios de resistência e módulo elástico à compressão axial da série HE 4530 - 2\%

\section{Resultados dos ensaios de compressão e módulo \\ Resultados dos ensaios de compressão axial do módulo elástico}

\begin{tabular}{|lcc|}
\hline & valores arredondados à significância mais próxima \\
\hline Indivíduo / corpo de prova & $\begin{array}{c}f_{c} \\
\mathrm{MPa}\end{array}$ & $\begin{array}{c}E^{*} \\
\mathrm{GPa}\end{array}$ \\
\hline Resultados & & \\
\hline HE 4530 - 2\%, CP1 & 84,8 & 32,5 \\
\hline HE 4530 - 2\%, CP2 & 78,8 & 30,7 \\
\hline HE 4530 - 2\%, CP3 & 82,6 & 32,3 \\
\hline MÉDIA & $\mathbf{8 2 , 1}$ & $\mathbf{3 1 , 8}$ \\
\hline DESVIO PADRÃO & $\mathbf{3 , 0}$ & $\mathbf{1 , 0}$ \\
\hline COEFCIENTE DE VARIAÇÃO & $\mathbf{3 , 7}$ & $\mathbf{3 , 1}$ \\
\hline * Refere-se ao módulo secante até 40\% da carga última. & \\
\hline
\end{tabular}

\subsection{3}

\section{Determinação da resistência à tração direta}

Esta seção trata da análise dos ensaios de tração direta realizados em corpos de prova tipo dog bone shaped. Foram realizados trinta ensaios que incluíram a família da matriz de concreto autoadensável e os concretos reforçados com cada um dos três tipos de fibras, nas três frações volumétricas estudadas (0,5 1,0 e 2,0 \%). Os resultados individuais estão apresentados na Figura 39 até a Figura 41 e resumidos na Tabela 19. O cálculo da tensão de tração foi feito com relação à área bruta da seção central do corpo de prova (68 mm) e, para cálculo da deformação, foi considerada a média absoluta dos deslocamentos dos LVDTs. O módulo à tração, por sua vez, foi calculado considerando o trecho linear dos gráficos tensão-deformação.

Dentre os ensaios realizados, o concreto de referência (sem reforço) obteve a maior resistência à tração $(6,04 \mathrm{MPa})$, representando aproximadamente $8 \%$ da resistência média do concreto à compressão axial (vide Figura 38). Vale salientar que as condições de cura dos corpos de prova foram diferentes para cada um destes ensaios. 


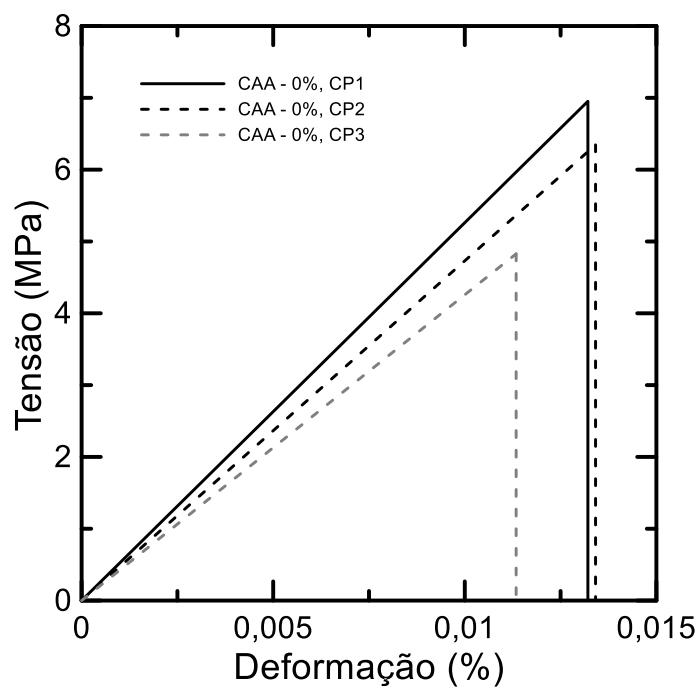

Figura 38 - Gráfico tensão-deformação à tração direta da matriz de concreto autoadensável

Os resultados médios cada uma das dez séries ensaiadas foram apresentadas na Tabela 13, na qual se fizeram necessárias as seguintes definições:

$\varepsilon_{p} \quad=$ deformação correspondente à primeira fissura;

$P_{p} \quad=$ carga de primeira fissura;

$f_{p} \quad=$ tensão de primeira fissura;

$P_{0,5}=$ carga residual correspondente à deformação de 0,5\%;

$f_{0,5}=$ tensão calculada em função da área íntegra da seção, à deformação de $0,5 \%$

$E \quad=$ modulo de elasticidade secante no limite de proporcionalidade;

$T_{3}$ = tenacidade correspondente à deformação de 3,0 \%;

$C V=$ coeficiente de variação. 
Tabela 13 - Resumo dos resultados dos ensaios de tração direta

\section{Resistências médias e energia de deformação}

Resultados de resistência, deformações de pico e pós-pico

de tração direta em corpos de prova dog bone shaped

\begin{tabular}{|c|c|c|c|c|c|c|c|c|c|c|}
\hline & & & & & & & & \multicolumn{3}{|c|}{ valores médios } \\
\hline Referência / & $\overline{\varepsilon_{p}}$ & $P_{p}$ & $f_{p}$ & $C V$ & $P_{0,5}$ & $f_{0,5}$ & $C V$ & $E$ & $C V$ & $T_{3}$ \\
\hline Família & $\%$ & $\mathrm{kN}$ & $\mathrm{MPa}$ & $\%$ & $\mathrm{kN}$ & $\mathrm{MPa}$ & $\%$ & $\mathrm{GPa}$ & $\%$ & $\mathrm{Jm}^{-3} 10^{4}$ \\
\hline CAA - $0 \%$ & 0,013 & 21,94 & 6,04 & 18 & - & - & - & 45 & 11 & - \\
\hline TW 50/25 - 0.5\% & 0,017 & 20,29 & 5,59 & 12 & 05,19 & 1,43 & 26 & 34 & 08 & 2,52 \\
\hline HE $45 / 30-0.5 \%$ & 0,016 & 18,02 & 4,96 & 17 & 04,62 & 1,27 & 48 & 36 & 14 & 2,31 \\
\hline HE 80/60 - 0.5\% & 0,016 & 17,36 & 4,68 & 09 & 05,04 & 1,35 & 35 & 29 & 29 & 2,61 \\
\hline TW 50/25 - 1\% & 0,014 & 18,32 & 5,05 & 06 & 07,39 & 2,04 & 18 & 33 & 14 & 3,27 \\
\hline HE $45 / 30-1 \%$ & 0,016 & 18,58 & 5,12 & 05 & 06,98 & 1,92 & 14 & 32 & 13 & 3,13 \\
\hline HE $80 / 60-1 \%$ & 0,015 & 21,24 & 5,85 & 00 & 06,16 & 1,70 & 55 & 34 & 10 & 2,98 \\
\hline TW 50/25 - $2 \%$ & 0,016 & 16,47 & 4,53 & 10 & 10,57 & 2,91 & 07 & 27 & 07 & 5,35 \\
\hline HE $45 / 30-2 \%$ & 0,013 & 16,50 & 4,54 & 08 & 09,18 & 2,53 & 23 & 34 & 17 & 4,38 \\
\hline HE $80 / 60-2 \%$ & 0,014 & 18,75 & 5,16 & 14 & 12,57 & 3,46 & 14 & 33 & 04 & 7,45 \\
\hline
\end{tabular}

Os ensaios de tração direta realizados nos concretos reforçados com fibras torcidas de razão de aspecto 50 resultaram nas resistências médias de tração de 5,59, 5,05 e 4,53 MPa, para as frações volumétricas de 0,5, 1,0 e 2,0\%, respectivamente (vide Figura 39 e Tabela 13). Para se observar a influência do incremento na fração volumétrica desta fibra, comparou-se a tenacidade média $T_{3}$ obtida na série TW 50/25 - 0,5\%, com as tenacidades obtidas nos demais percentuais de 1,0 e 2,0\%, resultando nos acréscimos de tenacidade de 30 e $112 \%$, respectivamente. 
a)

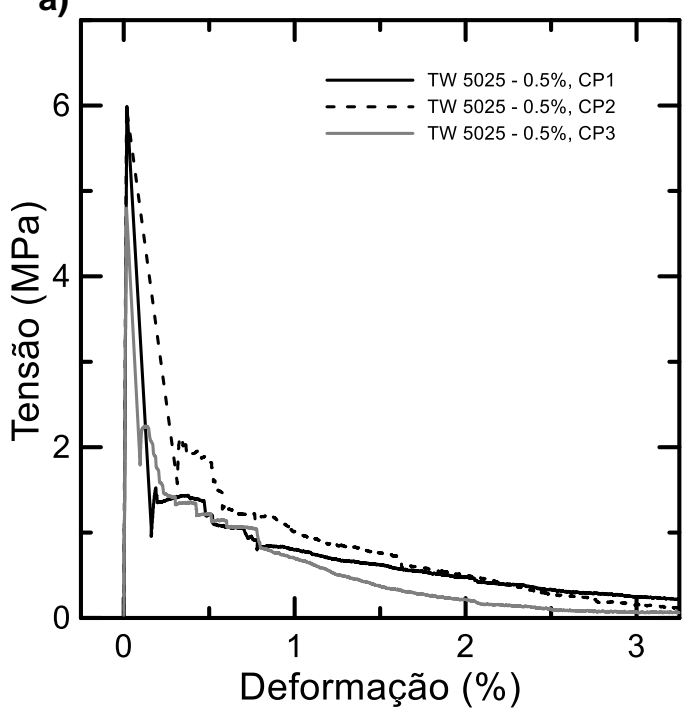

c)

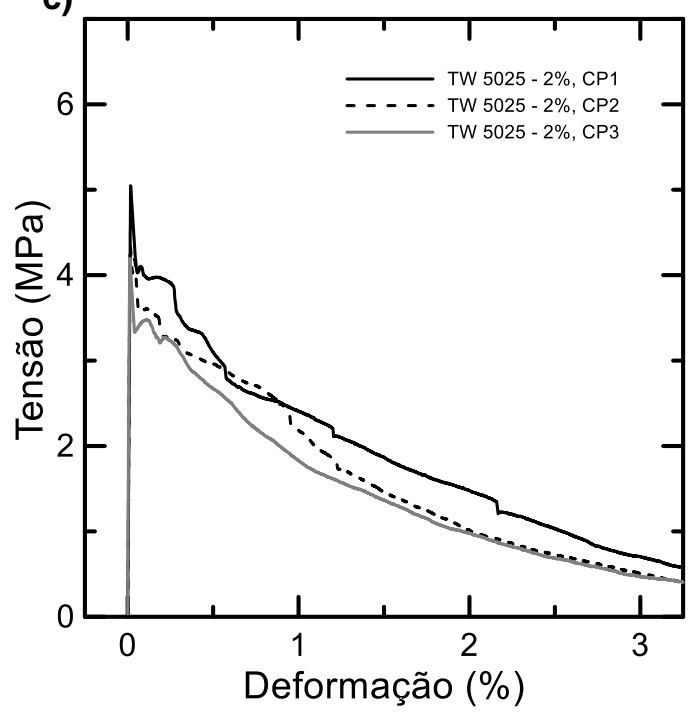

b)

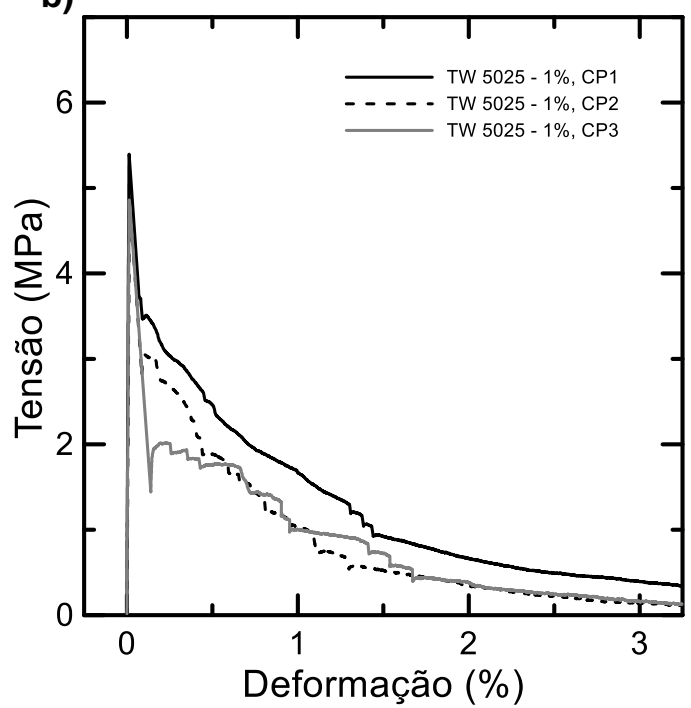

d)

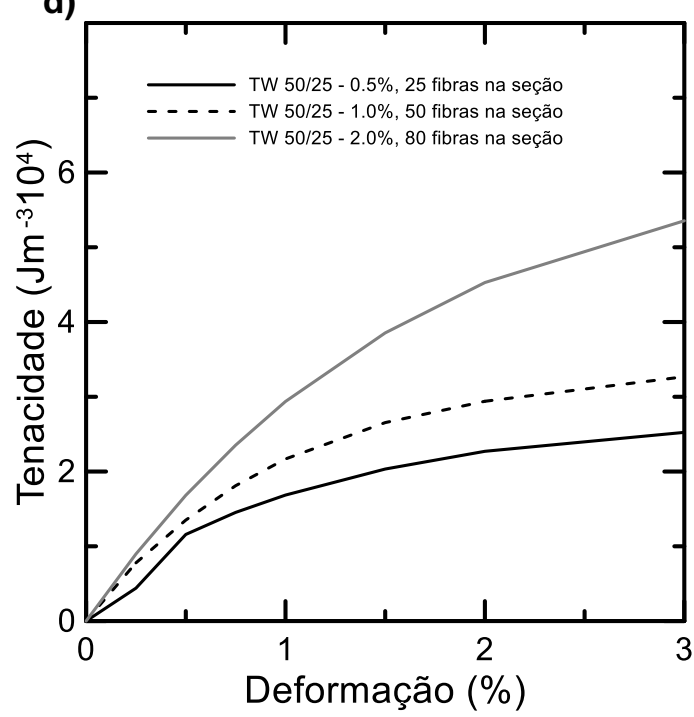

Figura 39 - Gráfico: a-c) tensão-deformação à tração direta dos concretos reforçados com fibras torcidas de razão de aspecto 50 e comprimento $25 \mathrm{~mm}$, nas frações volumétricas de 0,5, 1,0 e 2,0\%, respectivamente; d) comparativo de tenacidade-deformação médios à tração direta dos mesmos concretos de "a-c"

Os SFRSCCs formados a partir da inclusão das fibras HE 45/30 tiveram desempenho intermediário com respeito à carga residual $P_{0,5}$ e à tenacidade $T_{3}($ vide Figura 40 e Tabela 13). Os concretos reforçados com estas fibras resultaram nas resistências médias de 4,96, 5,12 e 4,54 MPa, para as frações volumétricas de $0,5,1,0$ e 2,0\%, respectivamente. Objetivando-se observar a influência do incremento na fração volumétrica desta fibra, comparou-se a tenacidade média $T_{3}$ obtida na série HE 45/30 - 0,5\% com as tenacidades obtidas nos demais percentuais de 1,0 e 2,0 \%, resultando nos acréscimos de tenacidade de 35 e $90 \%$, respectivamente. Estes acréscimos na tenacidade $T_{3}$ 
foram menos expressivos que os observados nos concretos reforçados com fibras torcidas.

a)

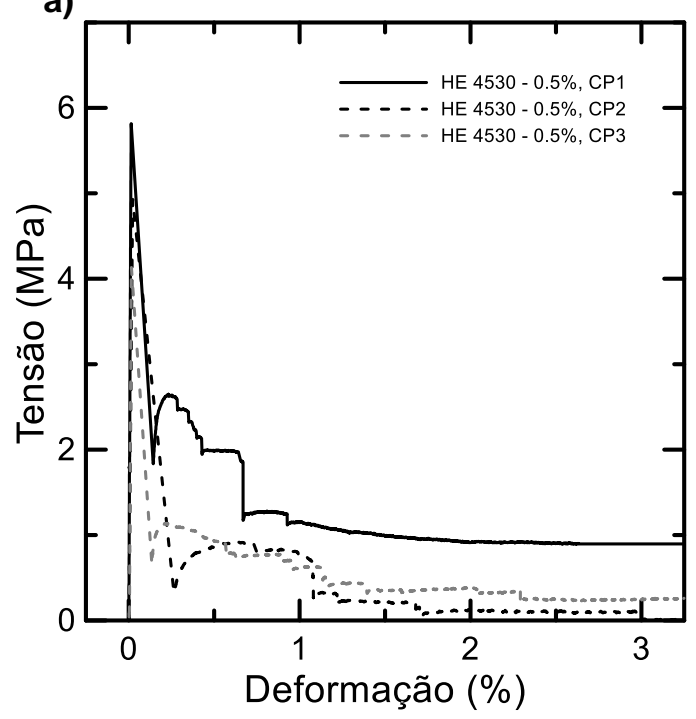

c)

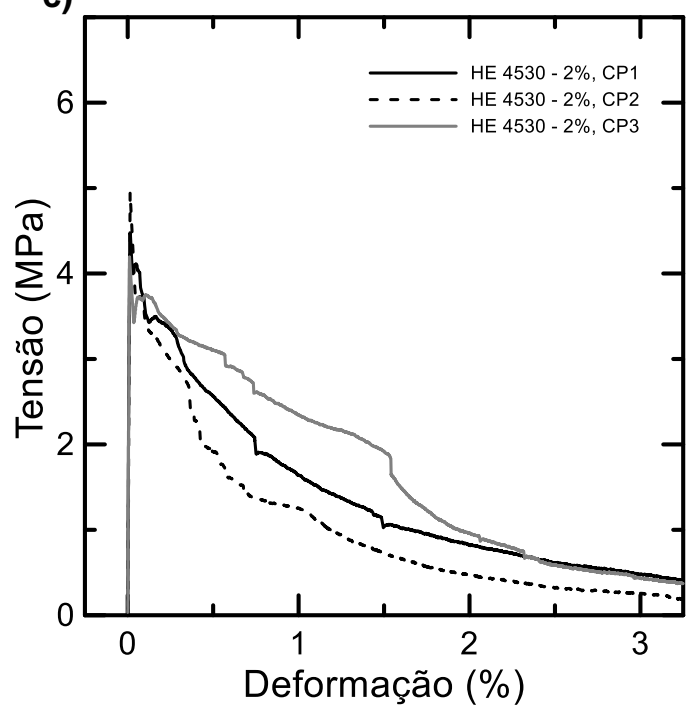

b)

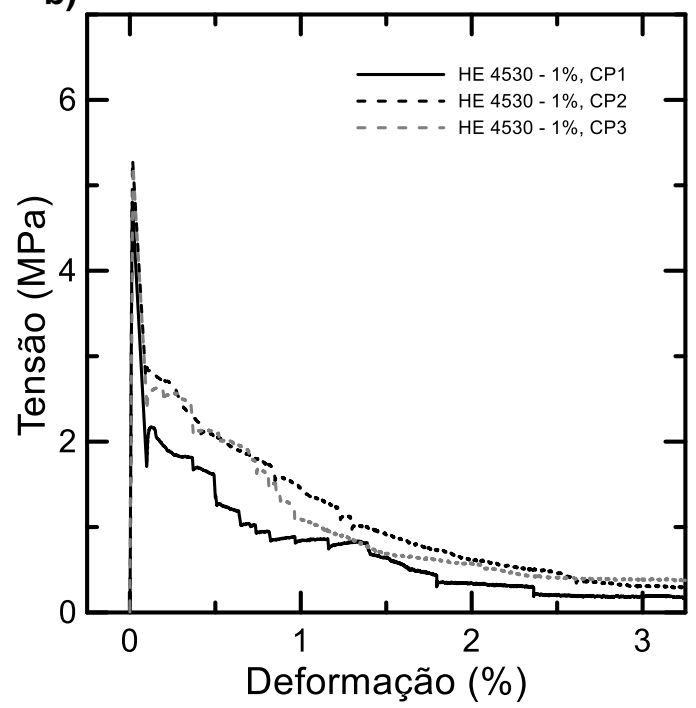

d)

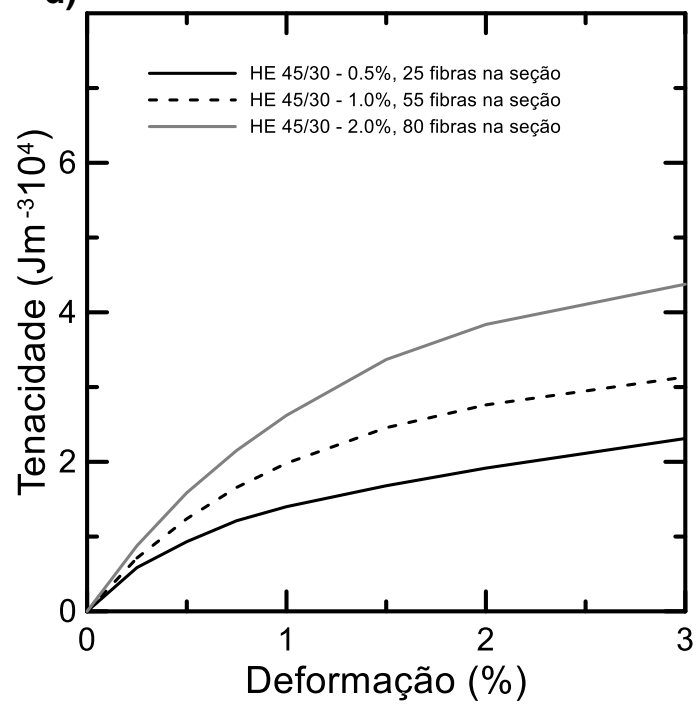

Figura 40 - Gráfico: a-c) tensão-deformação à tração direta de corpos de prova dog bone shaped moldados com concreto reforçado com fibras providas de ganchos nas extremidades com razão de aspecto 45 e comprimento $30 \mathrm{~mm}$, nas frações volumétricas de $0,5,1,0$ e 2,0 \%, respectivamente; d) comparativo de tenacidadedeformação médios à tração direta dos mesmos concretos de "a-c"

Uma vez analisados os ensaios de tração direta realizados nos concretos reforçados com fibras com ganchos de comprimento $60 \mathrm{~mm}$ e razão de aspecto 80 (vide Figura 41 e Tabela 13), obtiveram-se os resultados de resistência de 4,68, 5,85 e 5,16 MPa, para as frações volumétricas de 0,5, 1,0 e 2,0 \%, respectivamente. A fim de se observar a influência do incremento na fração volumétrica desta fibra, comparou-se a tenacidade média $T_{3}$ obtida na série 
HE 80/60 - 0,5\% com as tenacidades obtidas nos demais percentuais de 1,0 e $2,0 \%$, resultando nos acréscimos de tenacidade de 37 e $185 \%$, respectivamente. Esta relação representa um aumento na tenacidade em cinco vezes, que é maior do que aquele que se deu pelo aumento na fração volumétrica de fibras, de 0,5 para 2,0\%.

a)

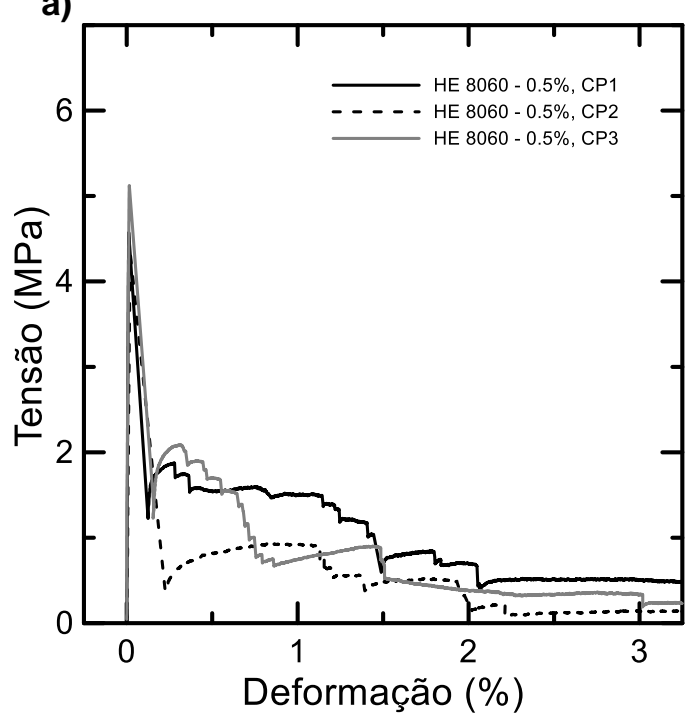

c)

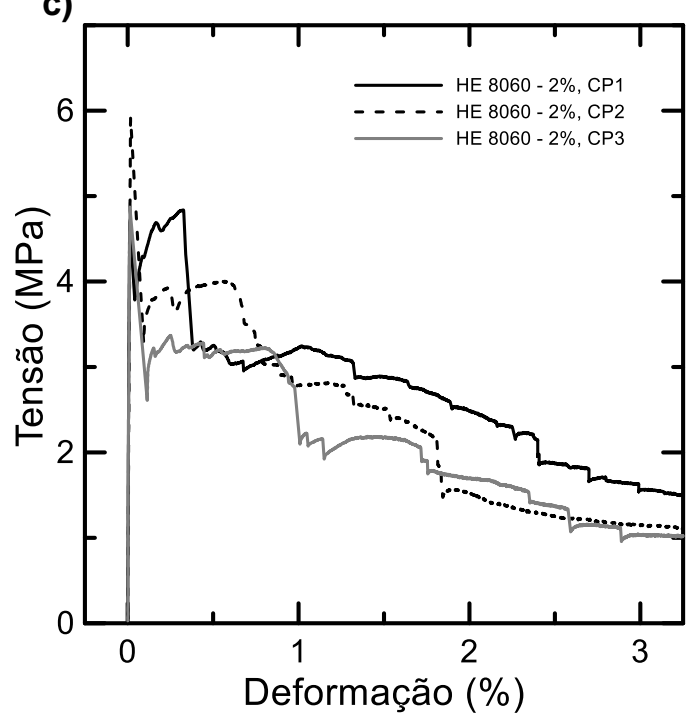

b)

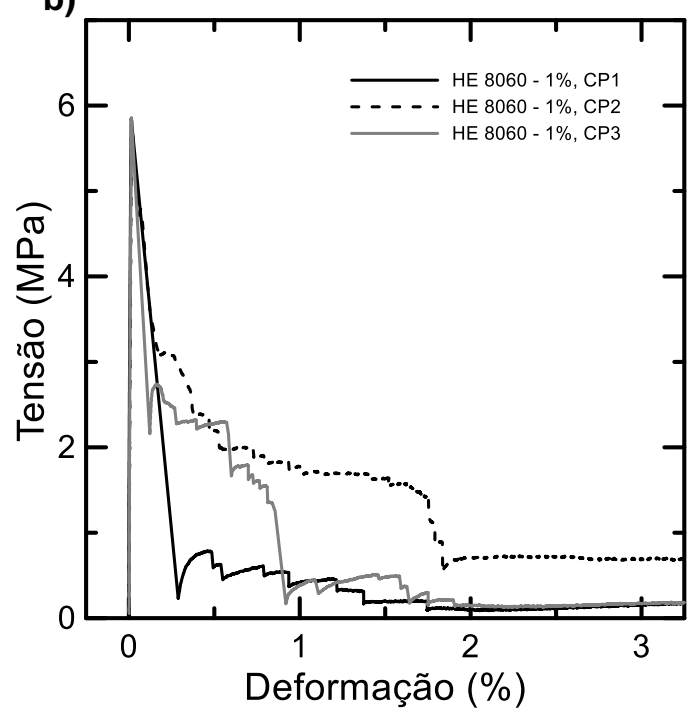

d)

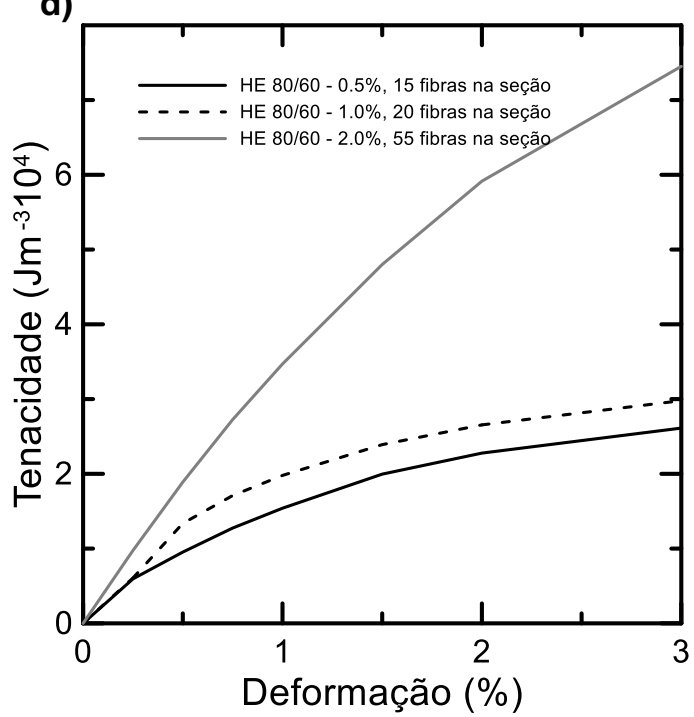

Figura 41 - Gráfico: a-c) tensão-deformação à tração direta de corpos de prova dog bone shaped moldados com concreto reforçado com fibras providas de ganchos nas extremidades com razão de aspecto 80 e comprimento $60 \mathrm{~mm}$, nas frações volumétricas de $0,5,1,0$ e 2,0 \%, respectivamente; d) comparativo de tenacidadedeformação médios à tração direta dos mesmos concretos de "a-c" 
O padrão de fissuras observado se caracterizou pelo surgimento de uma única fissura na região central do pescoço do corpo de prova (vide Figura $71 \mathrm{e}$ Figura 72). Em apenas uma das amostras, as deformações se concentraram em uma fissura diferente da primeira observada (vide Figura 42). Para todas as demais, a fissura central foi predominante com comportamento geral de strainsoftening.

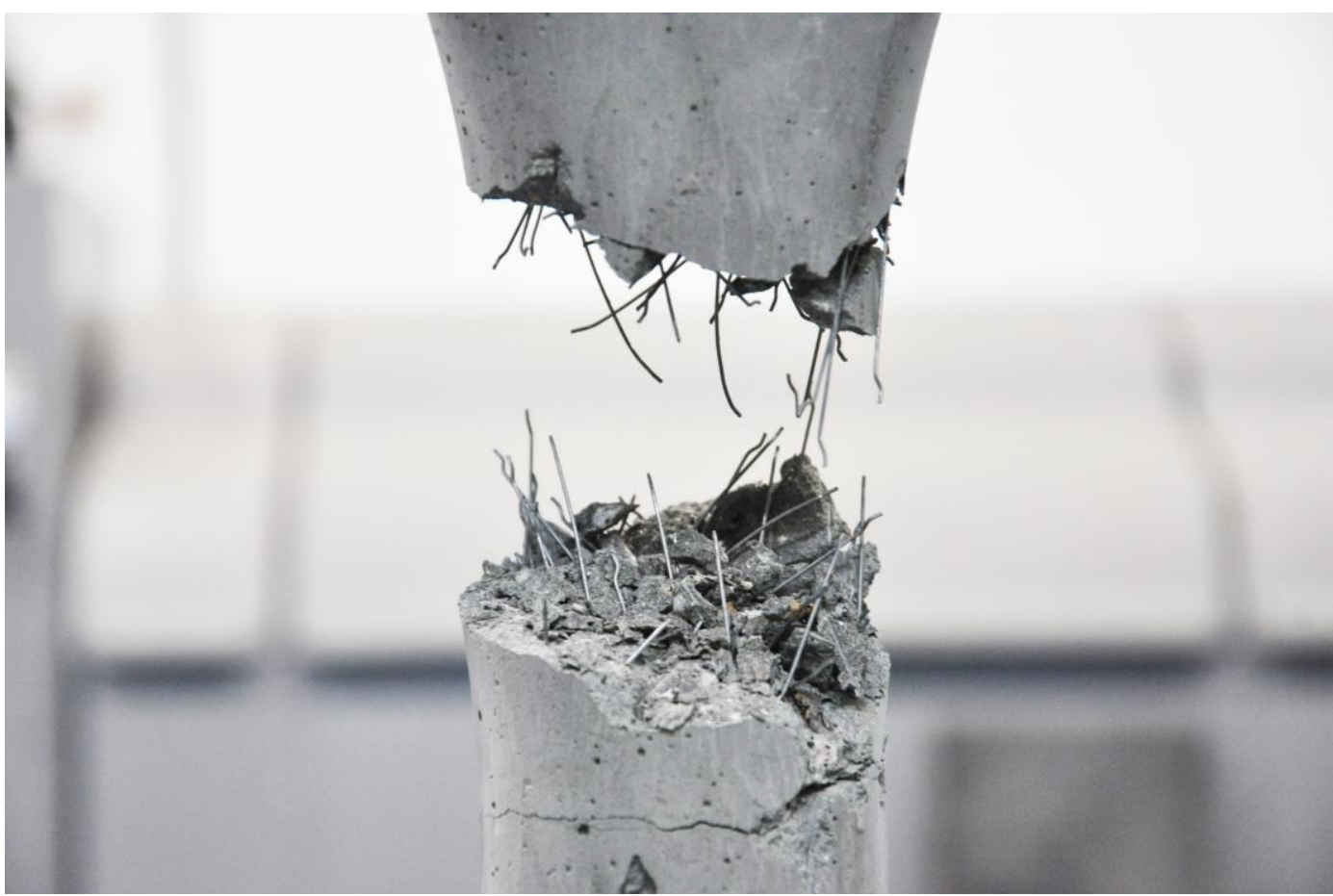

Figura 42 - Detalhe da seção rompida do corpo de prova HE 80/60 - 2\%, CP1

$\mathrm{Na}$ zona de pré-fissuração, as deformações foram incrementadas de 0 a 30 \% com a inclusão das fibras de aço na matriz e as cargas residuais da zona de pós-fissuração correspondentes à deformação 0,5 \% representaram, em média, $28 \%, 36 \%$ e $62 \%$ da carga de primeira fissura, para as frações volumétricas de 0,5, 1,0 e 2,0 \%, respectivamente (vide Figura 43). 


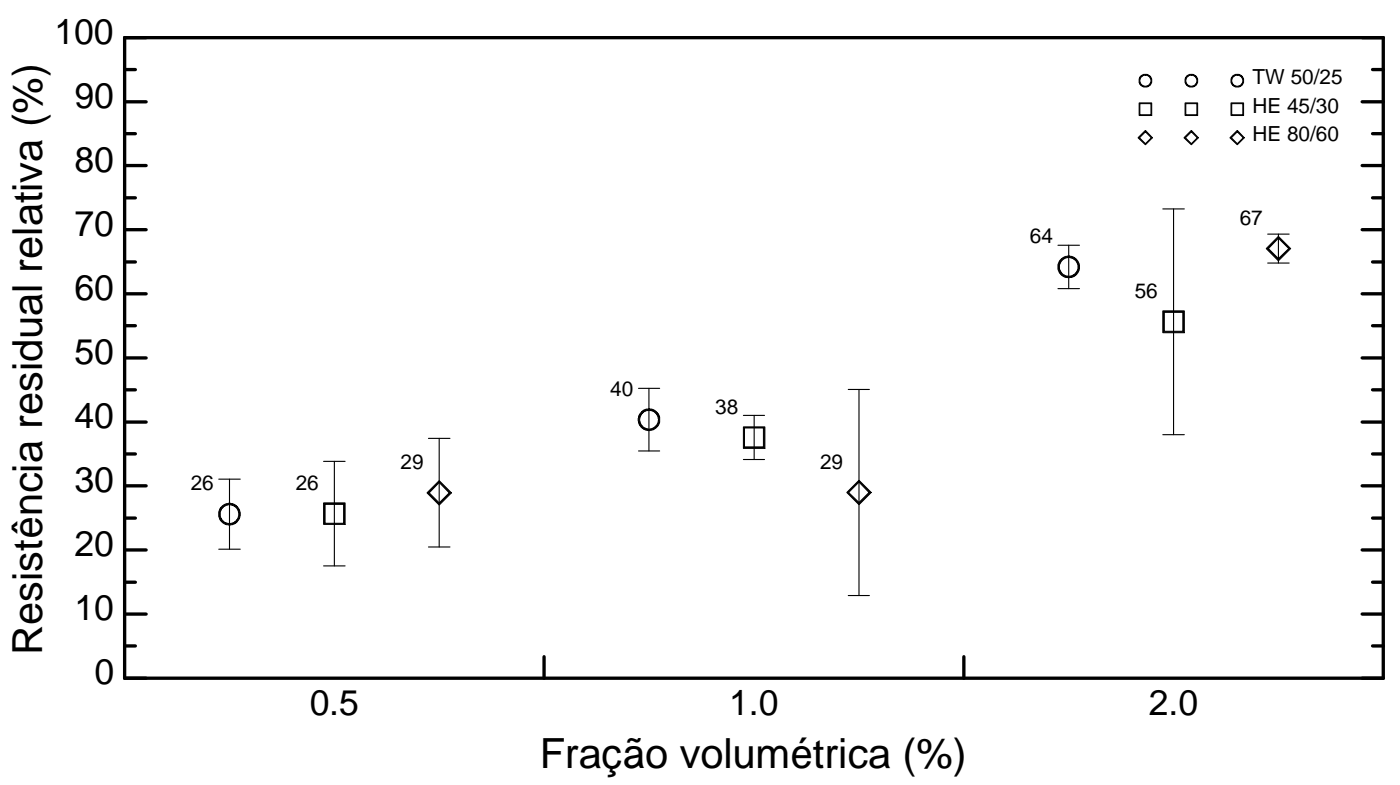

Figura 43 - Gráfico de resistências residuais na deformação de $0,5 \%$, com relação à de primeira fissura

Ao contrário do que se observou nos concretos reforçados com fibras de menores comprimentos, as resistências médias residuais $P_{0,5}$ dos concretos reforçados com fibras com ganchos de comprimento $60 \mathrm{~mm}$ e razão de aspecto 80 tiveram maiores variações nos resultados de ensaio, pois com menor número de fibras na seção, os corpos de prova passaram por processos de arrancamento de fibras muito mais localizados (vide decréscimos de cargas expressivos no ensaio do corpo de prova "CP2" na Figura 41a e corpo de prova "CP1" na Figura 41b). Vale ressaltar que, os SFRSCCs formados a partir das fibras HE 80/60 apresentam reologia prejudicada, sendo observada heterogeneidade nas misturas e pouca trabalhabilidade.

Uma vez analisada a tenacidade $T_{3}$ para os diferentes SFRSCCs produzidos na fração volumétrica de $2,0 \%$, observou-se grande disparidade nos resultados, no qual o desempenho promovido pelo reforço com fibras torcidas foi intermediário com relação às fibras com ganchos. A tenacidade média $T_{3}$ dos concretos reforçados com as fibras torcidas foi $22 \%$ maior do que o observado nos ensaios dos concretos com reforço de fibras com ganchos de razão de aspecto semelhante (vide Figura 44c) - fato que pode ser explicado pela influência da geometria complexa das fibras torcidas, no aumento de capacidade de absorção de energia. 

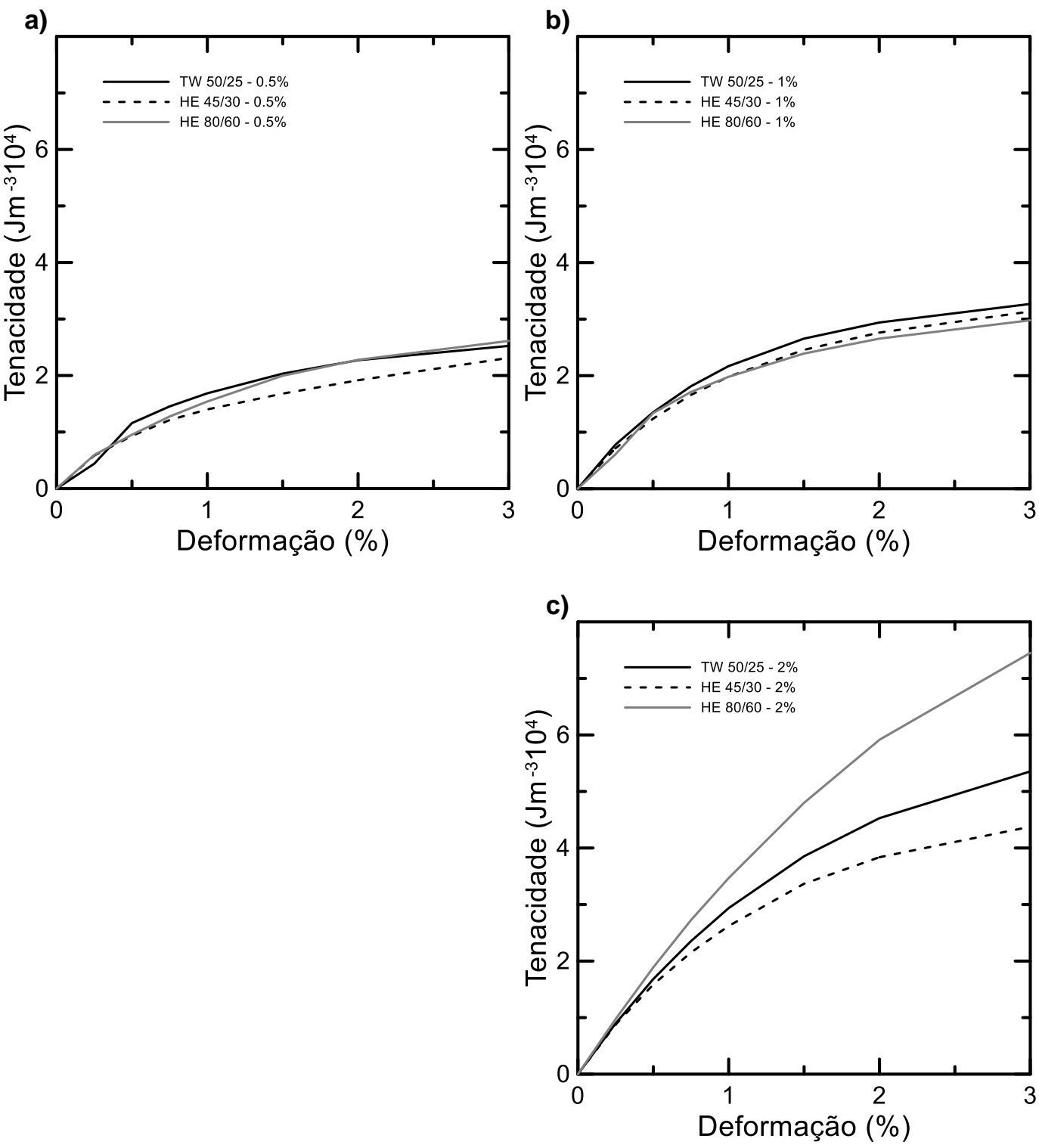

Figura 44 - Gráfico: a-c) tenacidade-deformação médios à tração direta de concretos reforçados com diferentes fibras de aço, em frações volumétricas crescentes

Os valores de tenacidade foram semelhantes para os concretos reforçados com todas as fibras analisadas, quando nas frações volumétricas de 0,5 e 1,0 \% (vide Figura 44). Este fato demonstra que os concretos com reforço de fibras longas foram igualmente capazes de dissipar energia com menor número médio de fibras na seção (vide Tabela 14).

Conclui-se, portanto, que o reforço fibroso trouxe incremento sensível nas deformações correspondentes à carga de pico, resultando no decréscimo dos módulos secantes como consequência. Em termos gerais, a adição de fibras 
aleatoriamente dispersas na matriz atribuiu ao concreto autoadensável a capacidade de carga residual à tração média de 60 \%.

Tabela 14 - Quantidade de fibras média na seção transversal

\section{Quantidade média de fibras na seção}

Quantidade média de fibras presentes no topo e base da seção transversal do corpo de prova dog bone shaped

\begin{tabular}{|lcccc|}
\hline \multicolumn{4}{|c|}{ valores médios arredondados ao múltiplo ou à significância mais próxima } \\
\hline Referência / Família & $\begin{array}{c}\text { Quantidade } \\
\text { und }\end{array}$ & $\begin{array}{c}\text { Desvio } \\
\text { und }\end{array}$ & $\begin{array}{c}A f / A_{c} \\
\%\end{array}$ & $\begin{array}{c}\text { Desvio } \\
\%\end{array}$ \\
\hline TW 50/25 - 0.5\% & 25 & 03 & 0,14 & 0,02 \\
\hline HE 45/30 - 0.5\% & 25 & 15 & 0,21 & 0,12 \\
\hline HE 80/60 - 0.5\% & 15 & 05 & 0,18 & 0,06 \\
\hline TW 50/25 - 1\% & 50 & 20 & 0,27 & 0,11 \\
\hline HE 45/30 - 1\% & 55 & 10 & 0,46 & 0,08 \\
\hline HE 80/60 - 1\% & 20 & 15 & 0,24 & 0,18 \\
\hline TW 50/25 - 2\% & 80 & 05 & 0,43 & 0,03 \\
\hline HE 45/30 - 2\% & 80 & 05 & 0,67 & 0,04 \\
\hline HE 80/60 - 2\% & 55 & 20 & 0,67 & 0,24 \\
\hline Obs.: Contagem por inspeção visual. & & & & \\
\hline
\end{tabular}

\subsection{4}

\section{Determinação da resistência à tração na flexão}

Este item se destina à avaliação do desempenho à flexão das dez séries de corpos de prova prismáticos ensaiadas, cujo comportamento foi observado para as zonas de pré e pós-fissuração. Para fins deste estudo, foi denominado como ponto de primeira fissura o ponto pertencente à zona de pré-fissuração cuja não linearidade dos gráficos carga-deflexão fica evidente. Depois de alcançado este ponto, denominado também como o ponto do "limite de proporcionalidade" (vide ASTM C 1018 [93]), classificou-se o comportamento pós-fissuração das amostras conforme sugerido por Naaman et al. [92], como de deflection-hardening ou de deflection-softening.

Em norma mais recente (ASTM C1609 [6]) utiliza-se o termo "carga de pico" como o ponto onde a inclinação do gráfico carga-deflexão é nula, fato que não ocorre nos materiais que exibem comportamento de deflection-hardening, acompanhados de múltipla fissuração. Por isto, as resistências residuais e os índices de tenacidade foram determinados nos pontos correspondentes à deflexões arbitradas. Para finalidade deste estudo, os ensaios de flexão foram realizados conforme as diretrizes do ASTM C 1018 [93], utilizando controle por 
deslocamento do atuador hidráulico, cujos resultados médios obtidos em cada uma das dez séries ensaiadas foram apresentadas na Tabela 15.

Tabela 15 - Resumo das resistências e energias de deformação médios à flexão de corpos de prova prismáticos

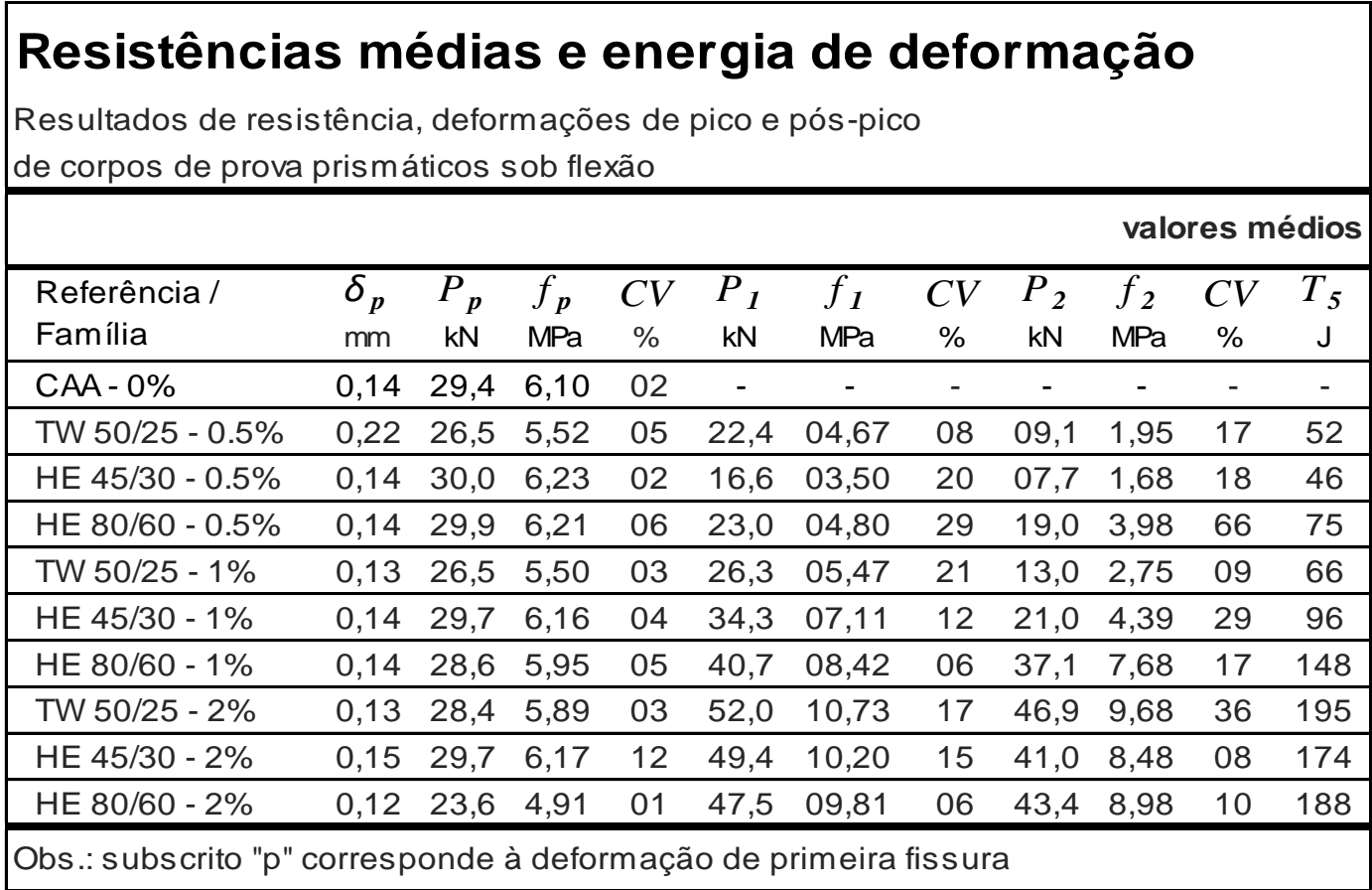

Onde,

$\delta_{p} \quad=$ deflexão de primeira fissura;

$P_{p} \quad=$ carga de primeira fissura;

$f_{p} \quad$ = tensão de primeira fissura;

$P_{1} \quad$ = carga residual correspondente à deflexão de $1 \mathrm{~mm}$;

$f_{1}$ = tensão calculada em função da área íntegra da seção, à deflexão de $1 \mathrm{~mm}$;

$P_{2}=$ carga residual correspondente à deflexão de $2 \mathrm{~mm}$;

$P_{2}=$ tensão calculada em função da área íntegra da seção, à deflexão de $2 \mathrm{~mm}$;

$T_{5} \quad$ = tenacidade correspondente à deflexão de $5 \mathrm{~mm}$. 
A resistência à tração na flexão da matriz foi de $6,10 \mathrm{MPa}$, representando $8 \%$ da sua resistência correspondente à compressão axial - exatamente o mesmo percentual obtido por meio dos ensaios de tração direta, porém menos variáveis (vide Figura 38 contra Figura 45 e Tabela 15). Os resultados das demais séries estão apresentados nas Figura 45 até Figura 48 e resumidos na Tabela 20.

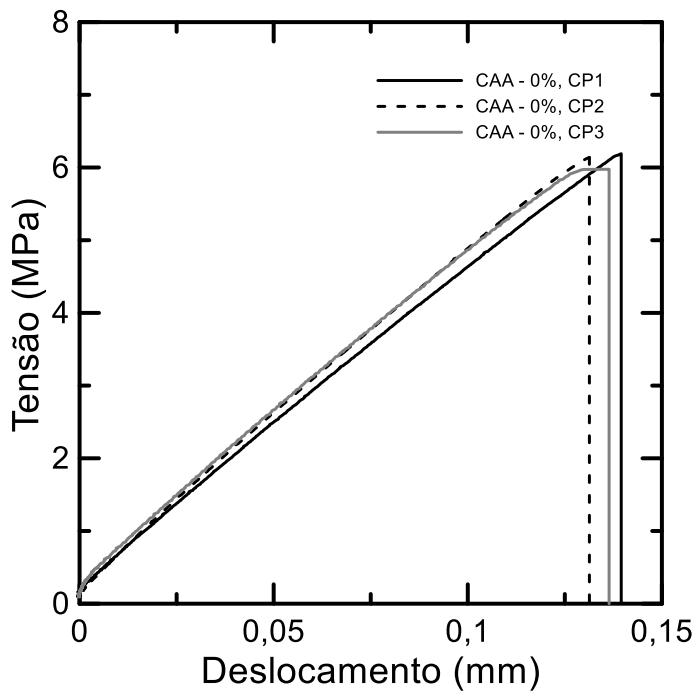

Figura 45 - Gráfico tensão-deformação à flexão da matriz de concreto autoadensável;

Os ensaios de flexão realizados nos concretos reforçados com fibras torcidas de razão de aspecto 50 resultaram nas resistências médias de 5,52 , 5,50 e 6,16 MPa, para as frações volumétricas de 0,5, 1,0 e 2,0\%, respectivamente (vide Figura 46 e Tabela 15).

Para se observar a influência do incremento na fração volumétrica das fibras TW 50/25 nos concretos (vide Figura 46), comparou-se a tenacidade média $T_{5}$ obtida na série TW 50/25 - 0,5\%, com as obtidas nos demais percentuais de 1,0 e 2,0\%, resultando nos acréscimos de tenacidade de 27 e $275 \%$, respectivamente. Este fato indica que, as áreas sob as curvas cresceram em proporção muito maior do que se aumentou a fração volumétrica de fibras. Enquanto se aumentou a quantidade de fibras em quatro vezes, a tenacidade correspondente à deflexão de $5 \mathrm{~mm}$, em contrapartida, aumentou em dez. 
a)

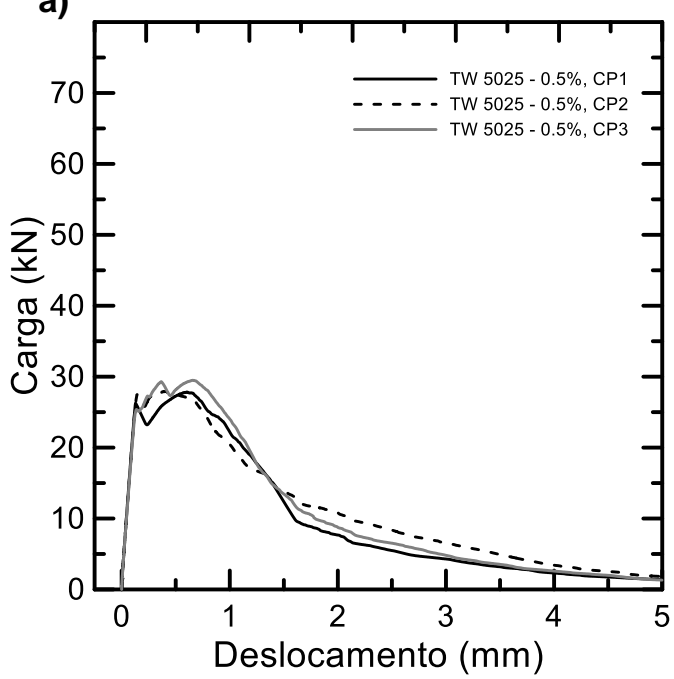

c)

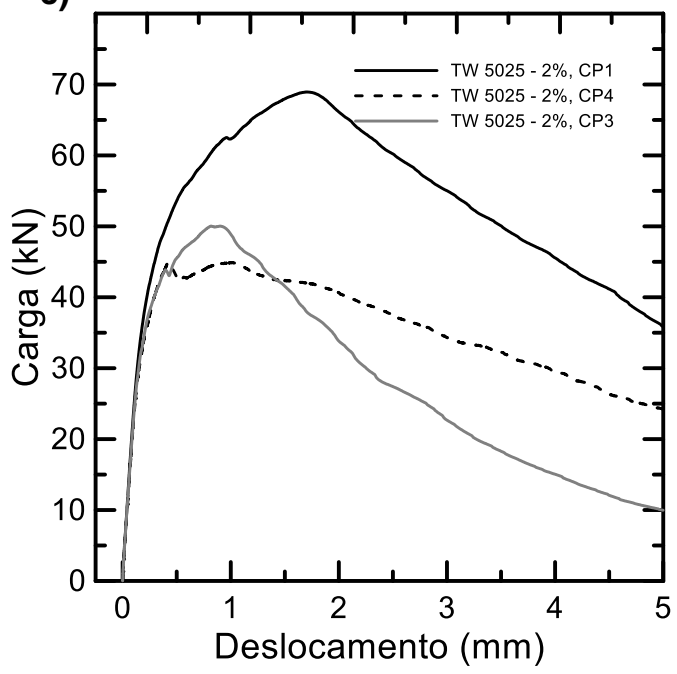

b)

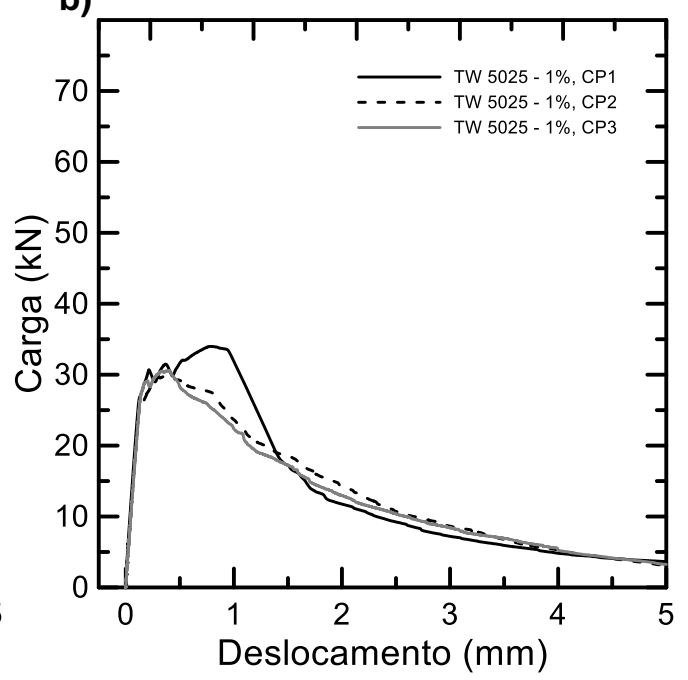

d)

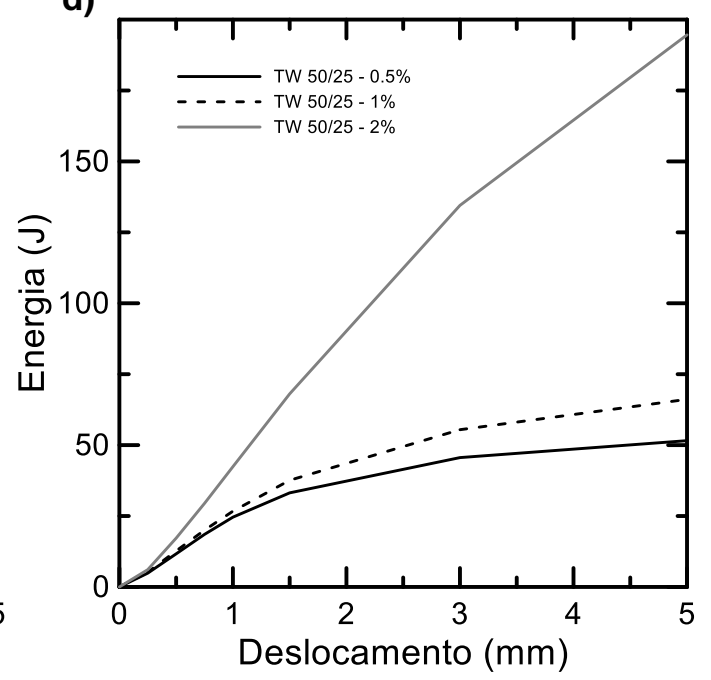

Figura 46 - Gráfico a-c) carga-deslocamento à flexão de concretos reforçados com fibras torcidas de razão de aspecto 50 e comprimento $25 \mathrm{~mm}$, nas frações volumétricas de $0,5,1,0$ e $2,0 \%$, respectivamente; d) comparativo de energiadeslocamento médios à flexão dos mesmos concretos de "a-c"

Os SFRSCCs formados a partir da inclusão de fibras HE 45/30 apresentaram as resistências de tração na flexão de 6,23, 6,16 e 6,17 MPa, para as frações volumétricas de 0,5, 1,0 e 2,0 \%, respectivamente (vide Figura 47 e Tabela 15). Para se observar a influência do incremento na fração volumétrica da fibra HE 45/30 nos concretos (vide Figura 47), comparou-se a tenacidade média $T_{5}$ obtida na série $\mathrm{HE} 45 / 30-0.5 \%$, com as obtidas nos demais percentuais de 1,0 e 2,0\%, resultando nos acréscimos de tenacidade de 107 e $278 \%$, respectivamente. 
a)

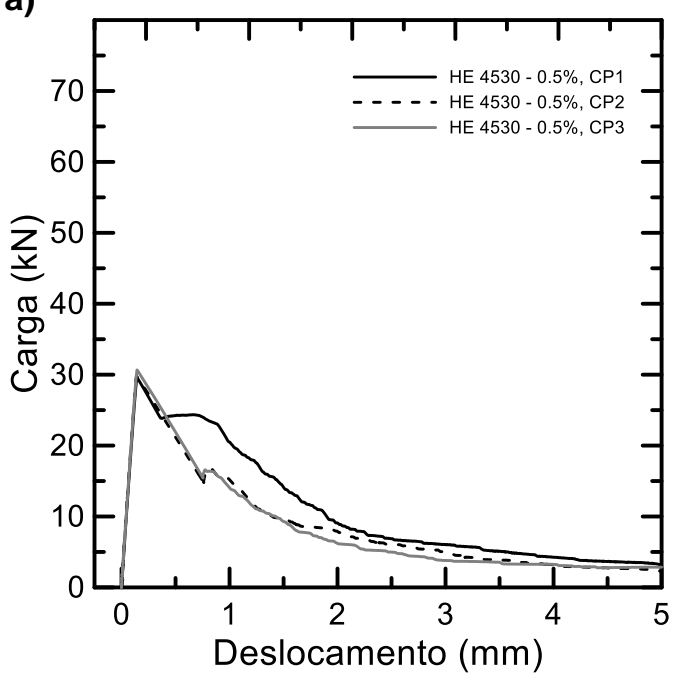

c)

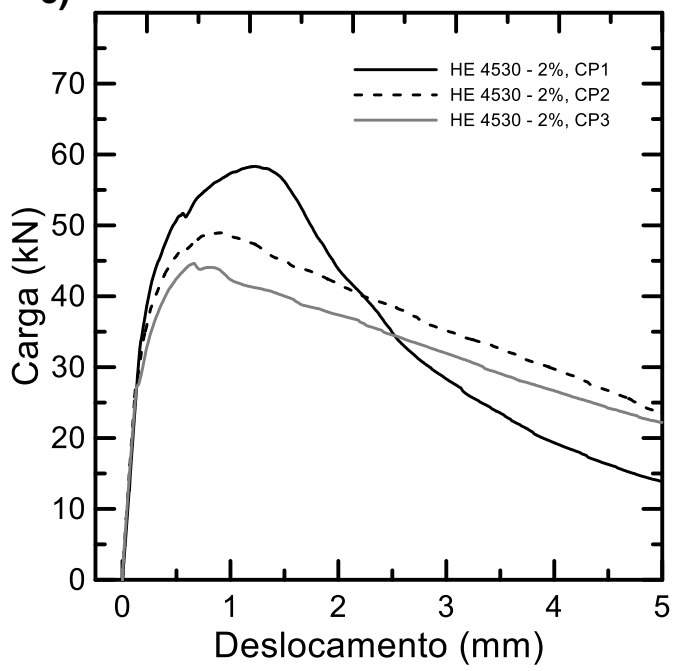

b)

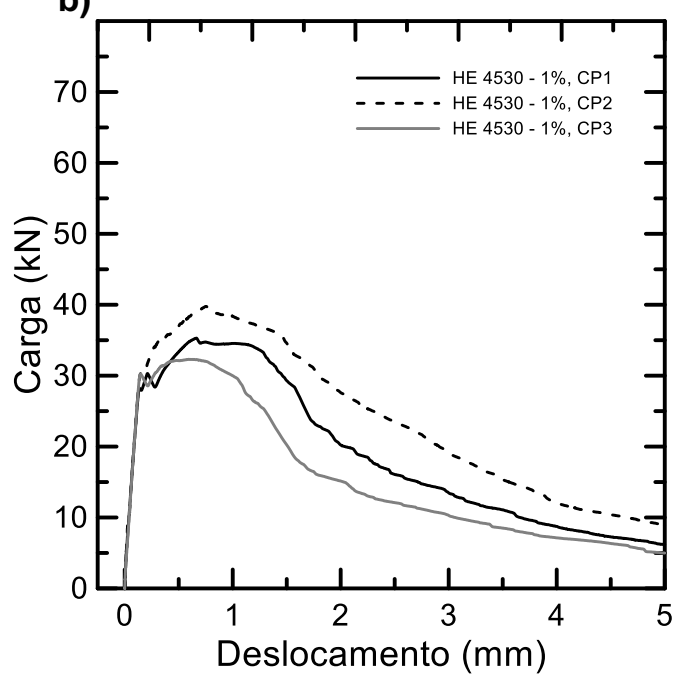

d)

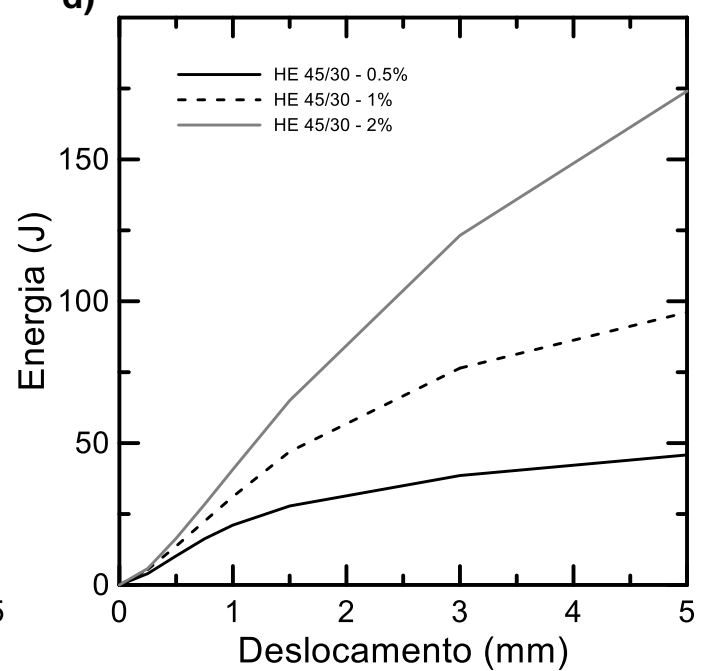

Figura 47 - Gráfico: a-c) carga-deslocamento à flexão de corpos de prova prismáticos moldados com concreto reforçado com fibras providas de ganchos com razão de aspecto 45 e comprimento $30 \mathrm{~mm}$, nas frações volumétricas de $\mathbf{0 , 5}$, 1,0 e 2,0\%, respectivamente; d) comparativo de energia-deslocamento médios à flexão dos mesmos concretos de "a-c"

Uma vez analisados os ensaios de flexão dos concretos reforçados com fibras com ganchos de comprimento $60 \mathrm{~mm}$ e razão de aspecto 80 (vide Figura 48 e Tabela 13), observaram-se as resistências de tração na flexão de 6,21, 5,95 e 4,91 MPa, para as frações volumétricas de 0,5, 1,0 e 2,0 \%, respectivamente. A fim de se observar a influência do incremento nas frações volumétricas das fibras HE 80/60 nos concretos (vide Figura 48), comparou-se a tenacidade média $T_{5}$ obtida na série HE $80 / 60$ - 0,5\% com as obtidas nos demais percentuais de 1,0 e 2,0\%, resultando nos acréscimos de tenacidade de 97 e $151 \%$, respectivamente. 
a)

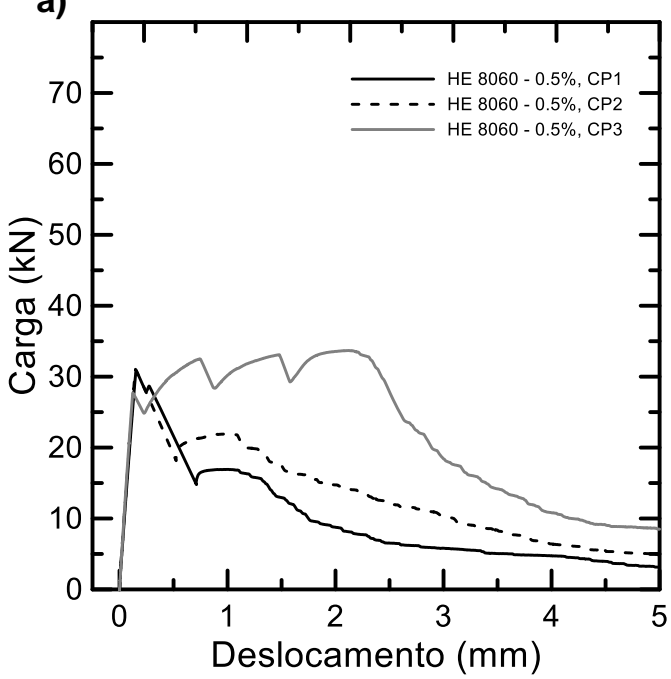

c)

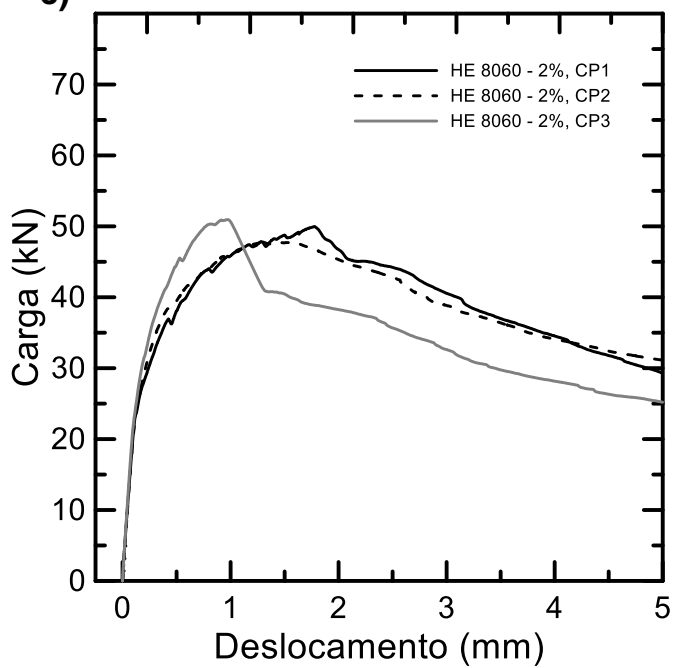

b)

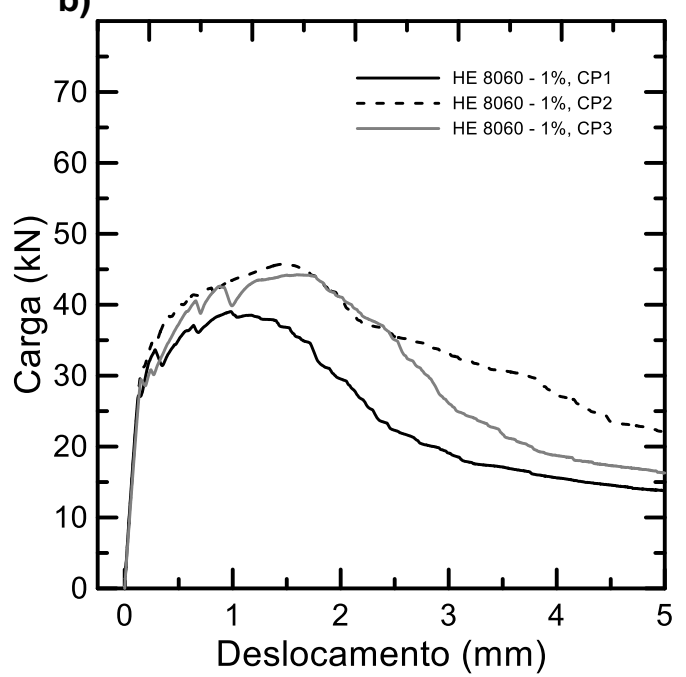

d)

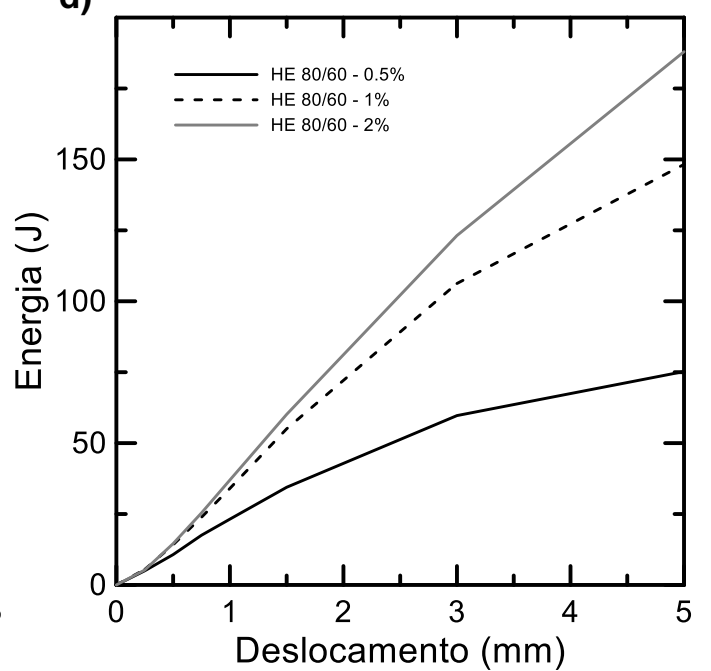

Figura 48 - Gráfico: a-c) carga-deslocamento à flexão de corpos de prova prismáticos moldados com concreto reforçado com fibras providas de ganchos com razão de aspecto 80 e comprimento $60 \mathrm{~mm}$, nas frações volumétricas de 0,5 , 1,0 e 2,0\%, respectivamente; d) comparativo de energia-deslocamento médios à flexão dos mesmos concretos de "a-c"

A inclusão das fibras de aço na matriz de concreto autoadensável incrementou de forma significativa as resistências residuais à flexão. Na deflexão de $1 \mathrm{~mm}$, as cargas residuais representaram em média, $72 \%, 118 \%$ e $182 \%$ da carga correspondente à primeira fissura, para as frações volumétricas de 0,5 , 1,0 e 2,0\%, respectivamente (vide Figura 49). 


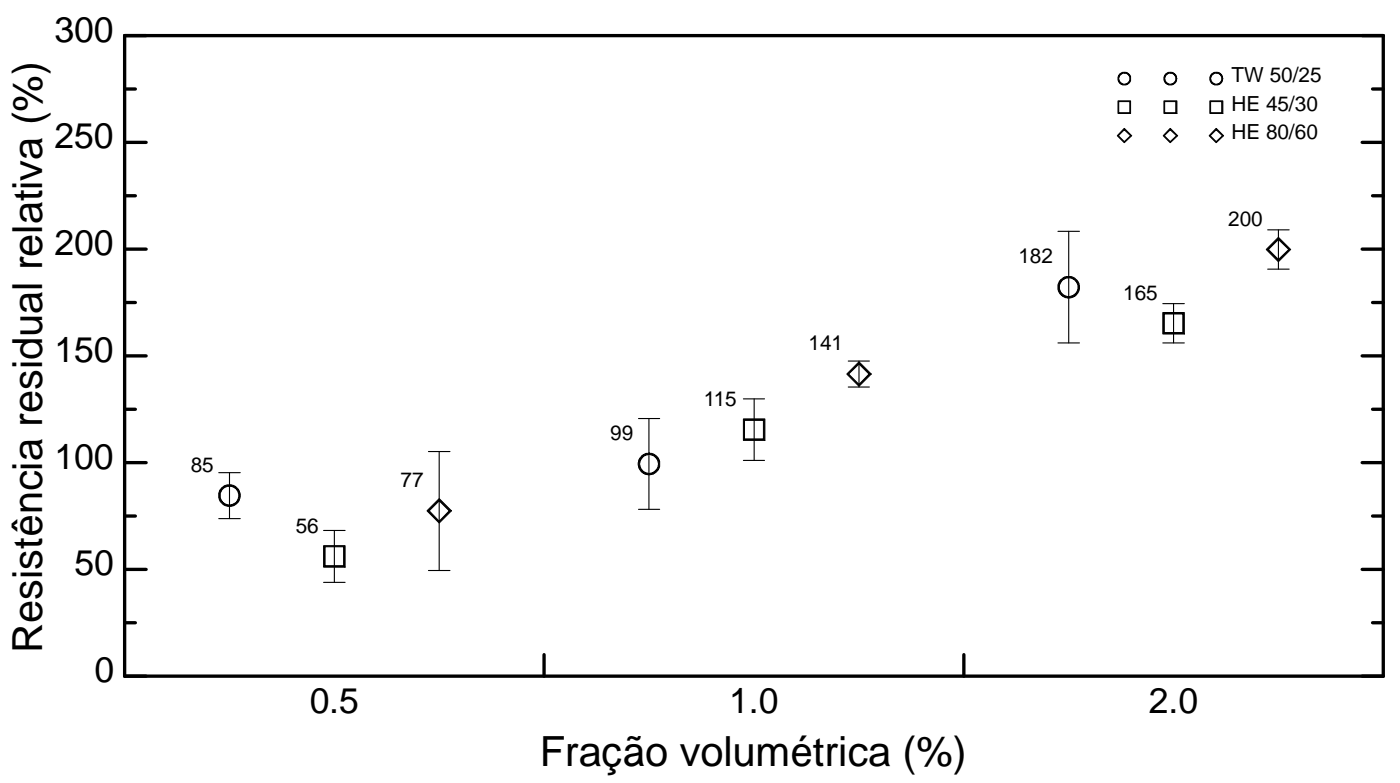

Figura 49 - Gráfico de resistências residuais na deflexão de $1 \mathrm{~mm}$, com relação à de primeira fissura

Uma vez observadas sobre o ponto de vista da deflexão de $2 \mathrm{~mm}$, as cargas residuais representaram em média, $42 \%, 83 \%$ e $161 \%$ da carga correspondente à primeira fissura, para as frações volumétricas de 0,5, 1,0 e 2,0\%, respectivamente (vide Figura 50 ).

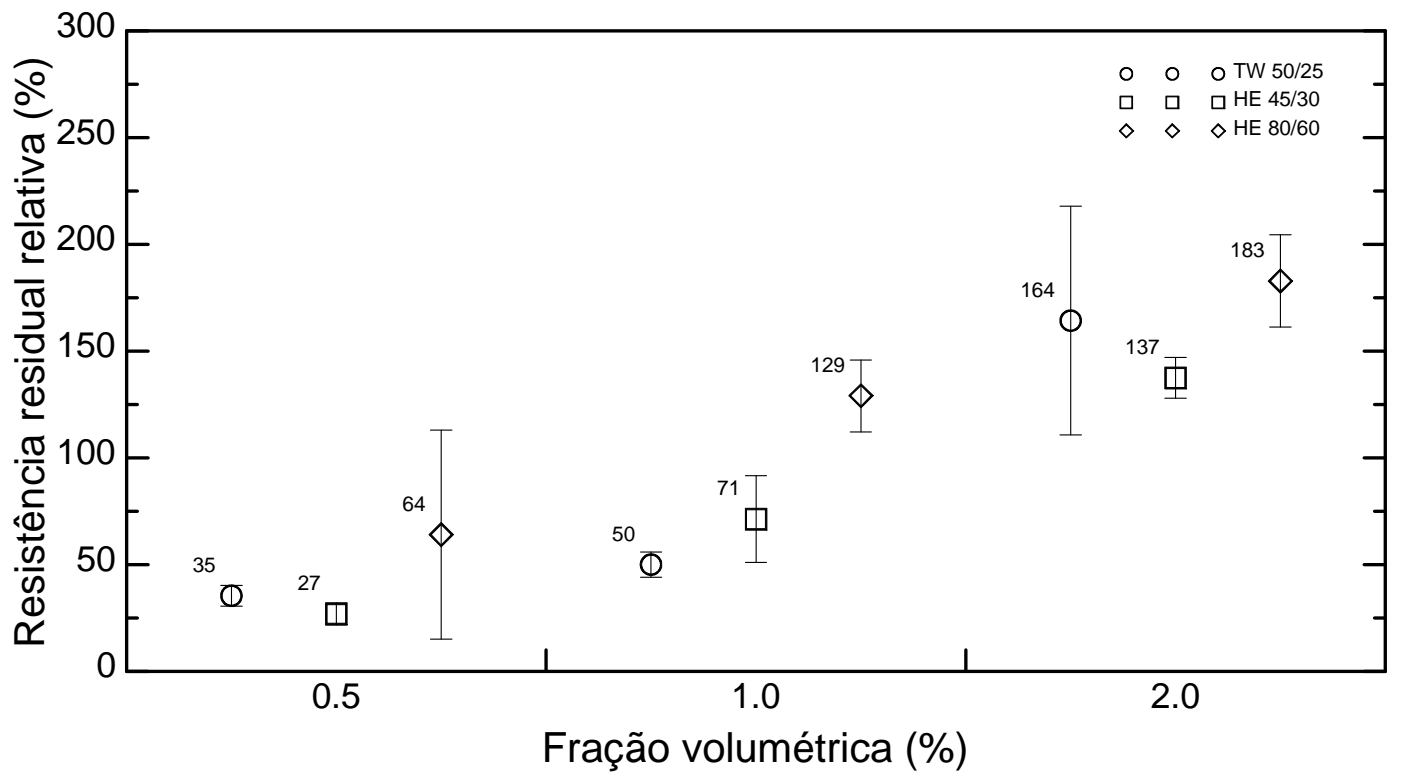

Figura 50 - Gráfico de resistências residuais na deflexão de $2 \mathrm{~mm}$, com relação à de primeira fissura 
Os valores de tenacidade à flexão foram semelhantes para todos os concretos reforçados com fibras, quando na fração volumétrica de 2,0 \%. Já nas frações volumétricas de 0,5 e 1,0\%, os valores foram mais dispersos (vide Figura 51). Observando-se a Figura 51a e Figura 51b, nota-se ainda, que os SFRSCCs contendo fibras torcidas não obtiveram incrementos na tenacidade média significativos com o aumento da fração volumétrica de 0,5 para 1,0 \%.

a)

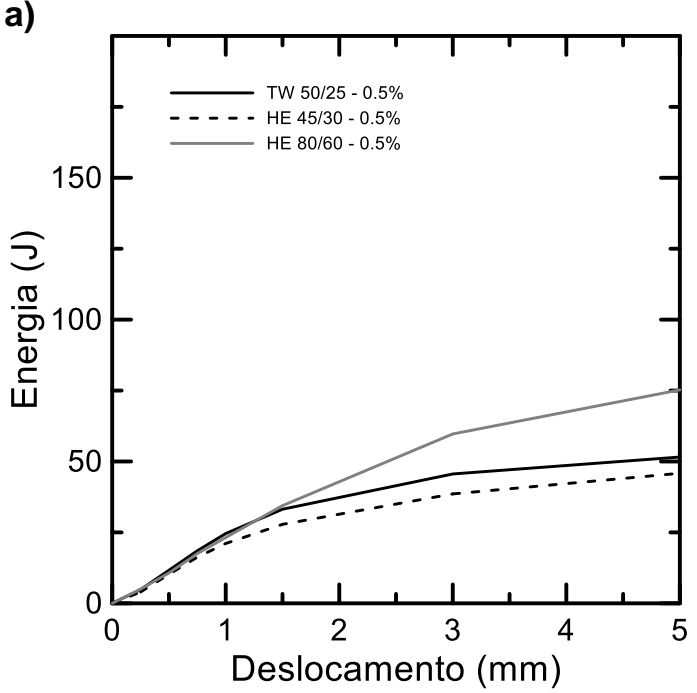

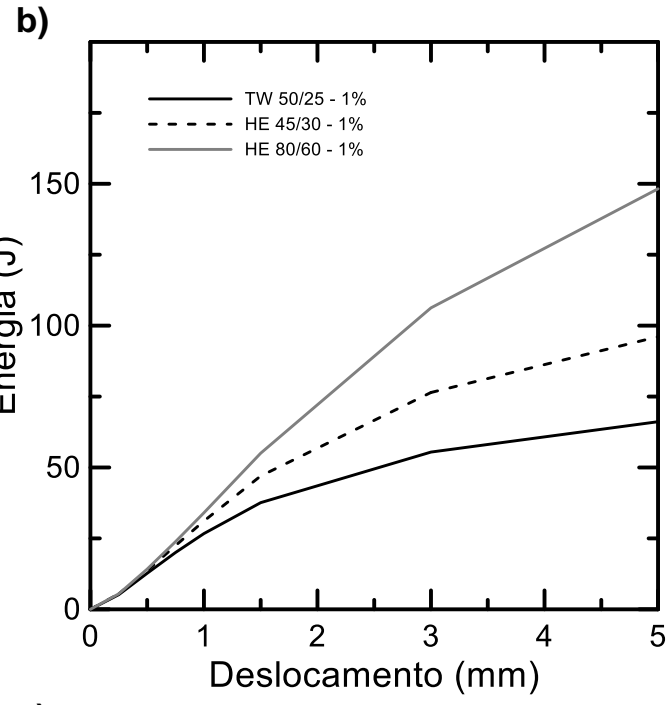

c)

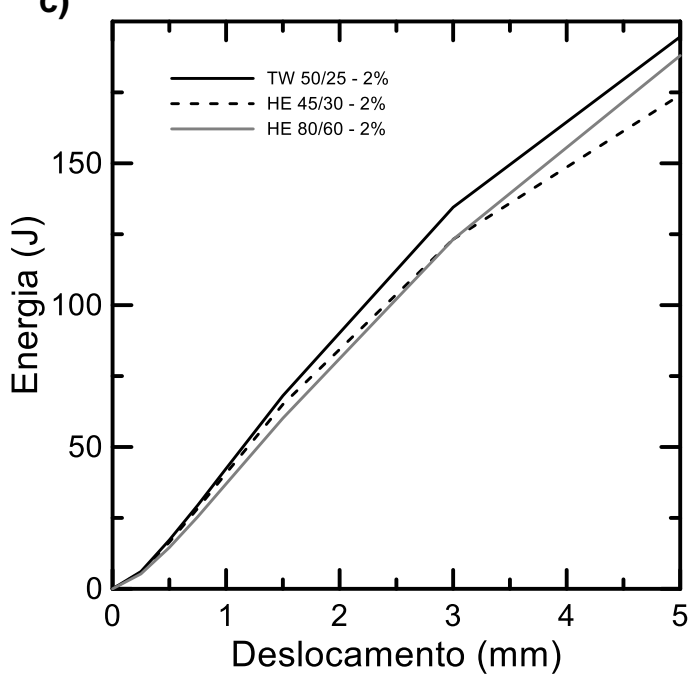

Figura 51 - Gráfico: a-c) energia-deslocamento médios à flexão de concretos reforçados com diferentes fibras de aço, em frações volumétricas crescentes

Ao contrário das demais séries, os ensaios realizados nos corpos de prova com reforço de fibras $\mathrm{HE} \mathrm{80/60} \mathrm{mostraram} \mathrm{relações} \mathrm{mais} \mathrm{estreitas} \mathrm{em} \mathrm{termos} \mathrm{da}$ tenacidade média $T_{5}$ para as frações volumétricas de 1,0 e 2,0\%. Este comportamento pode ser relacionado pelo maior comprimento ancorado entre ambos os lados de uma fissura, pois em uma seção transversal, o número de 
fibras HE 80/60 é sempre menor do que o das demais fibras estudadas. Em contrapartida, a série de concretos reforçados com HE 80/60 - 2,0 \% obtiveram os menores valores de resistência à primeira fissura $f_{p}$, que pode ser resultado dos efeitos negativos observados no estado fresco destas misturas (vide seção 4.1.1).

Os ensaios de flexão realizados nos corpos de prova reforçados com a fração volumétrica de $0,5 \%$ apresentaram cargas de pico facilmente identificáveis, conforme ilustrado no ASTM C1609 [6]. Nas demais frações (1,0 e 2,0 \%), a ruptura se caracterizou pelo comportamento de deflection-hardening, mostrando diversos estágios de queda e de recuperação de resistências. O padrão de fissuração observado nos ensaios foi de uma única fissura sinuosa predominante, dentro do terço médio dos corpos de prova (vide Figura 73 e Figura 74), excetuando-se apenas o corpo de prova HE 80/60 - 0.5\%, CP3, que apresentou a formação duas outras fissuras aproximadamente equidistantes da primeira, em ambos os lados.

Em geral, os concretos reforçados com fibras torcidas tiveram melhor desempenho quando comparados com aqueles reforçados com fibras com ganchos, pois se notou o comportamento de deflection-hardening em todos os corpos de prova ensaiados (vide Figura 46). Entretanto, na fração volumétrica de $1,0 \%$ o reforço promovido pelas fibras de aço torcidas teve menor eficácia aparente, sendo comparável com os resultados à meia fração.

\section{2}

\section{Ensaios semiestruturais}

\subsection{1}

\section{Ensaios de flexão em painéis circulares}

Este item se destina à avaliação do desempenho à flexão de painéis circulares de concreto agrupados em seis séries de corpos de prova, cujo comportamento foi observado para as zonas de pré e pós-fissuração. Para finalidade deste estudo, foi denominado como "ponto de primeira fissura" o ponto pertencente à zona de pré-fissuração cuja não linearidade do gráfico carga-deflexão fica evidente, pois a norma utilizada como referência ASTM C1550 [1] prevê a identificação da carga de pico, que só é possível de determinar nos casos em que se observa o comportamento de deflection- 
softening. O desempenho do reforço fibroso foi quantificado em termos da energia absorvida do início do carregamento até valores de deflexões centrais predeterminados, como proposto na norma ASTM C1550 [1]. Buscou-se verificar também, para cada um destes pontos de interesse, a abertura de fissuras correspondente (tal como em Rambo [32] e Rambo et al. [88], vide seção 3.4.2.1).

Por meio da análise da Figura 52, observa-se que emprego do reforço em volumes crescentes de fibras de aço mudou o comportamento de falha dos painéis circulares à flexão de abrupta para dúctil (vide Figura 52).

a)
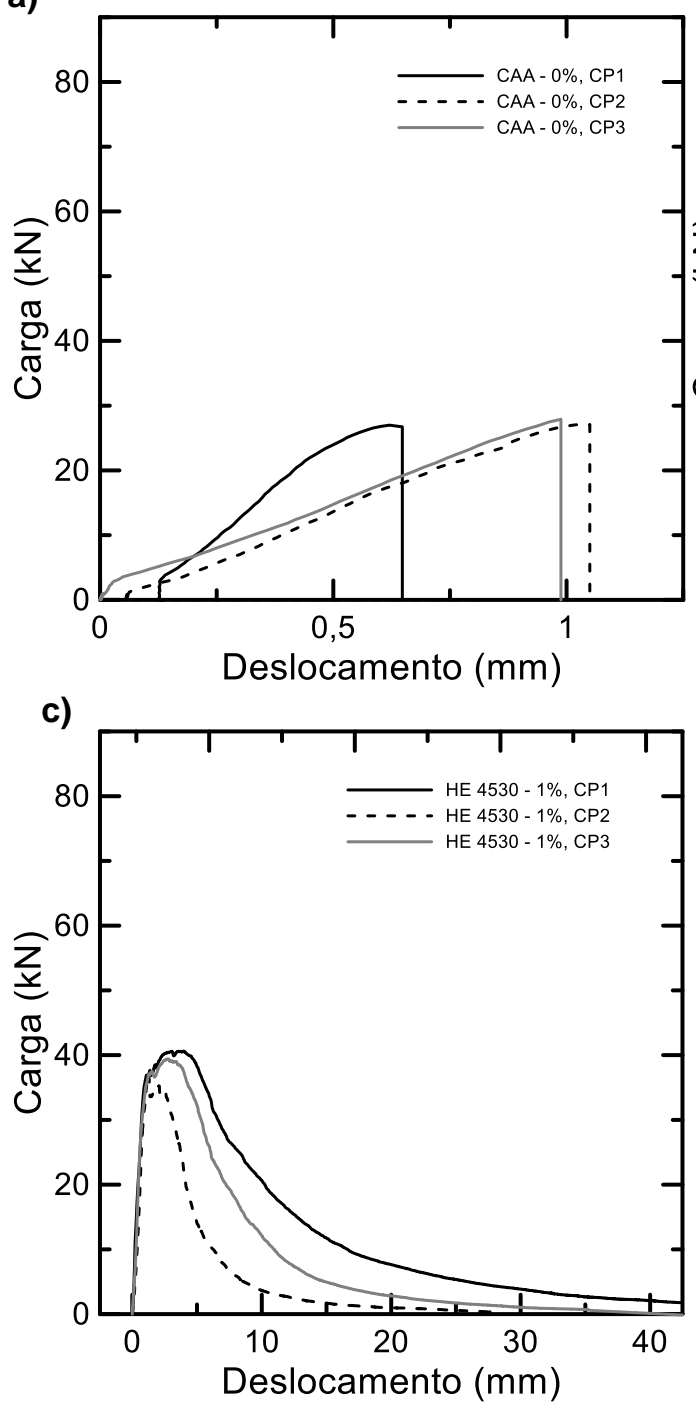

b)

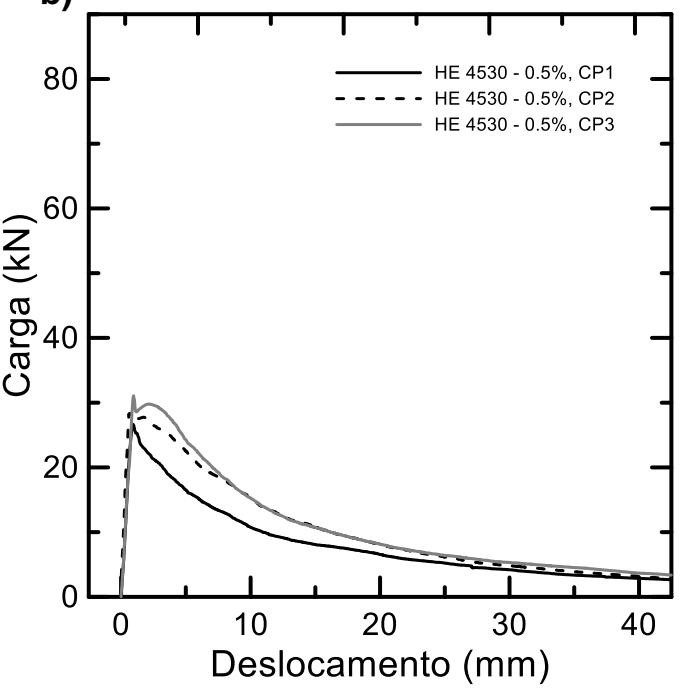

d)

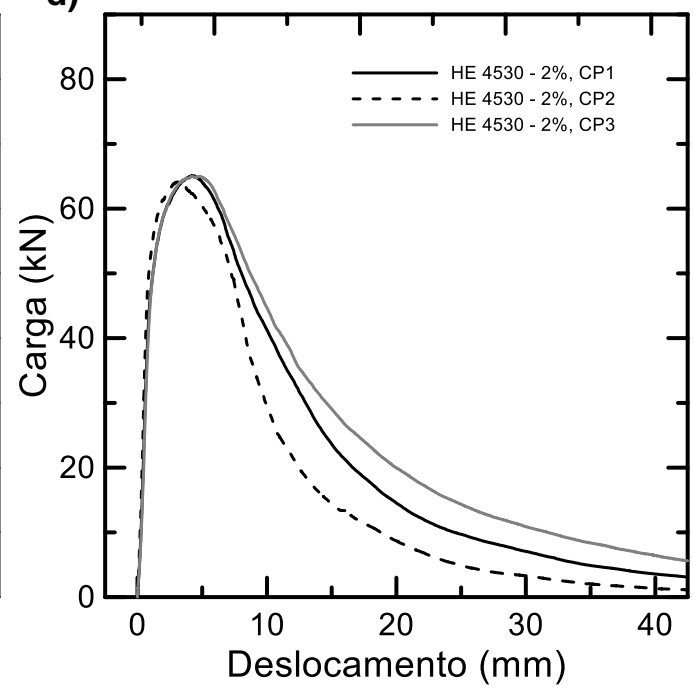

Figura 52 - Gráfico carga-deslocamento à flexão de painéis circulares moldados com: a) matriz de concreto autoadensável; b-d) concreto autoadensável reforçado com fibras de aço providas de ganchos de razão de aspecto 45 e comprimento $30 \mathrm{~mm}$, nas frações volumétricas de 0,5, 1,0 e 2,0 \%, respectivamente 
Os resultados das seis séries contempladas nesta análise estão apresentados na Figura 52, Figura 53 e os resultados médios cada uma das dez séries ensaiadas foram apresentadas na Tabela 16, cujos seguintes termos se mostraram necessários para sua análise:

$\delta_{p} \quad=$ deslocamento de primeira fissura;

$P_{p} \quad=$ carga de primeira fissura;

$C V=$ coeficiente de variação;

$P_{0,1}=$ carga correspondente à abertura média de fissuras de $0,1 \mathrm{~mm}$;

$P_{5} \quad$ = carga residual correspondente à deflexão de $5 \mathrm{~mm}$;

$P_{10} \quad$ carga residual correspondente à deflexão de $10 \mathrm{~mm}$;

$T_{40} \quad=$ tenacidade correspondente à deflexão de $40 \mathrm{~mm}$.

Tabela 16 - Resumo dos resultados de flexão em painéis circulares

\section{Resistências médias e tenacidade à flexão}

Resultados de carga e deflexão de base

de painéis circulares sob flexão

valores médios

\begin{tabular}{|lcccccccccc|}
\hline \multirow{2}{*}{ Referência / Família } & $\begin{array}{c}\delta_{\boldsymbol{p}} \\
\mathrm{mm}\end{array}$ & $\begin{array}{c}P_{\boldsymbol{p}} \\
\mathrm{kN}\end{array}$ & $\begin{array}{c}C V \\
\%\end{array}$ & $\begin{array}{c}P_{\boldsymbol{0}, \boldsymbol{1}} \\
\mathrm{kN}\end{array}$ & $\begin{array}{c}C V \\
\%\end{array}$ & $\begin{array}{c}P_{5} \\
\mathrm{kN}\end{array}$ & $\begin{array}{c}C V \\
\%\end{array}$ & $\begin{array}{c}P_{10} \\
\mathrm{kN}\end{array}$ & $\begin{array}{c}C V \\
\%\end{array}$ & $\begin{array}{c}T_{40} \\
\mathrm{~kJ}\end{array}$ \\
\hline CAA - 0\% & 0,9 & 27,3 & 02 & - & - & - & - & - & - & - \\
\hline HE 45/30 - 0.5\% & 0,9 & 28,7 & 08 & 28,3 & 07 & 21,1 & 19 & 13,8 & 19 & 303 \\
\hline HE 45/30 - 1\% & 0,8 & 31,6 & 07 & 30,9 & 07 & 28,2 & 45 & 12,1 & 70 & 318 \\
\hline HE 45/30 - 2\% & 1,0 & 44,3 & 10 & 39,3 & 14 & 68,4 & 13 & 49,2 & 26 & 897 \\
\hline TW 50/25 - 2\% & 0,9 & 45,9 & 04 & 41,2 & 03 & 63,1 & 04 & 38,5 & 21 & 766 \\
\hline HE 80/60 - 2\% & 0,9 & 41,2 & 01 & 35,9 & 02 & 69,3 & 02 & 68,9 & 15 & 1145 \\
\hline Obs .: subs crito "p" corresponde à deformação de primeira fissura & & & \\
\hline
\end{tabular}

Durante a fase ascendente dos gráficos (vide Figura 52), observou-se grande dissipação de energia e grandes deslocamentos correspondentes. Este efeito se traduziu pelo aumento de rigidez à flexão promovido pelas pontes de fibras, cujo comportamento de hardening foi observado a partir da fração volumétrica de 1,0\%. A exceção foi a série HE 45/30 - 0,5\%, que apresentou pico pronunciado seguido do comportamento de deflection-softening (como previsto no ASTM C1550 [1]). 

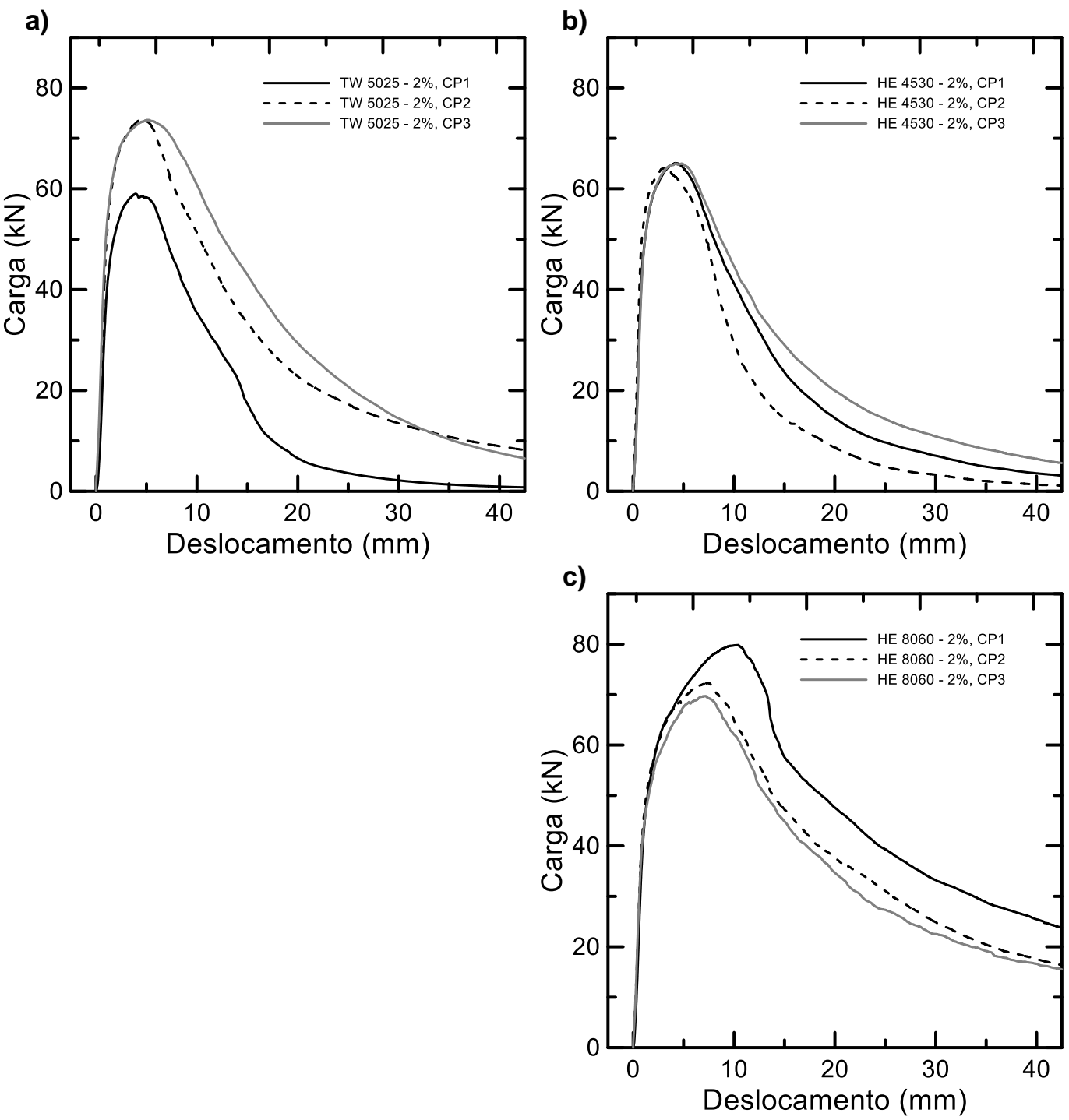

Figura 53 - Gráficos carga-deslocamento à flexão de painéis circulares moldados com concreto autoadensável reforçado com a fração volumétrica de $2,0 \%$ de fibras de aço do tipo: a) torcidas de razão de aspecto 50 e comprimento $25 \mathrm{~mm}$; b) fibras com ganchos de razão de aspecto 45 e comprimento $30 \mathrm{~mm}$; c) fibras com ganchos de razão de aspecto 80 e comprimento $60 \mathrm{~mm}$

De modo geral, os gráficos carga-deslocamento obtidos nos ensaios de flexão em painéis circulares se mostraram menos variáveis do que aqueles observados nos gráficos de flexão em prismas, mostrando sua melhor reprodutibilidade.

A inclusão de fibras de aço na matriz autoadensável incrementou de forma significativa as resistências residuais à flexão dos painéis circulares. Na deflexão de $5 \mathrm{~mm}$, as cargas residuais da série HE 45/30 representaram em média, $73 \%, 88 \%$ e $138 \%$ da carga correspondente à primeira fissura, para as 
frações volumétricas de 0,5, 1,0 e 2,0\%, respectivamente (vide Figura 54a). Uma vez analisando-se no ponto de vista da deflexão $10 \mathrm{~mm}$, as cargas residuais da série HE 45/30 representaram em média, $48 \%$, $38 \%$ e $84 \%$ da carga correspondente à primeira fissura, para as frações volumétricas de 0,5, 1,0 e 2,0\%, respectivamente (vide Figura 54b).

a)

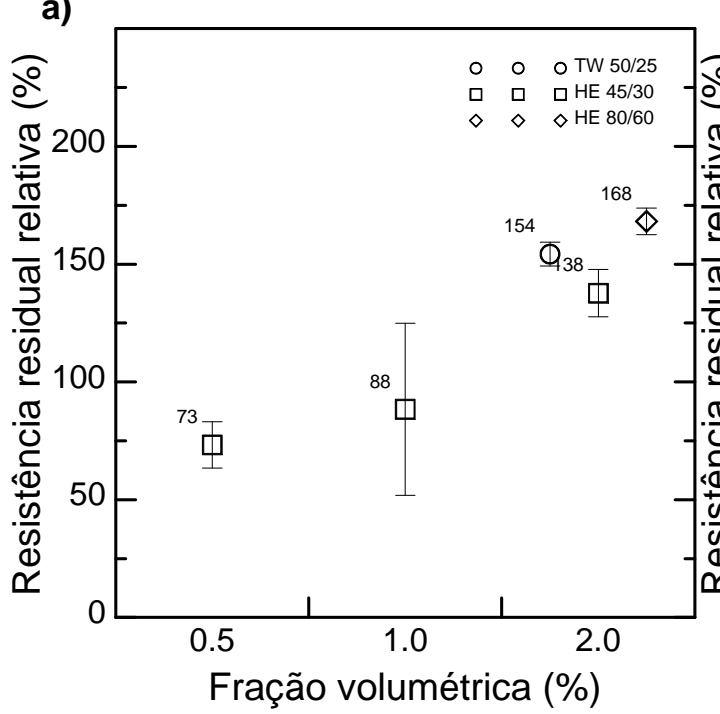

b)

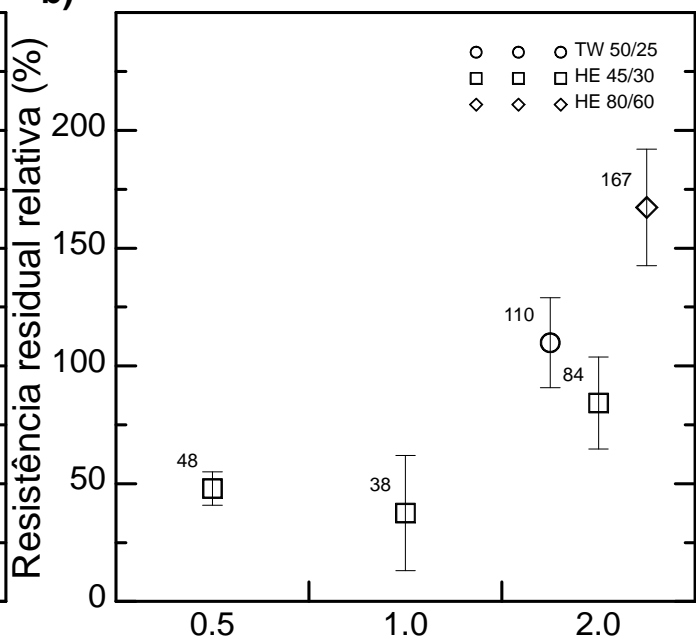

Fração volumétrica (\%)

Figura 54 - Gráfico: a) de resistências residuais na deflexão de $5 \mathrm{~mm}$, com relação à de primeira fissura; b) de resistências residuais na deflexão de $10 \mathrm{~mm}$, com relação à de primeira fissura

Comparando-se o desempenho dos concretos reforçados com as diferentes fibras no percentual de 2,0\% (vide Figura 53, Figura 54a e Figura 54b), notou-se que os concretos reforçados com fibras de razão de aspecto 80 obtiveram as maiores cargas residuais, pois as regiões de pico observadas nos gráficos carga-deslocamento se mantiveram até deflexões da ordem de $10 \mathrm{~mm}$. Uma vez analisados os painéis reforçados com as fibras de razão de aspecto 45 e 50, observa-se que as cargas residuais $P_{5}$ e $P_{10}$ foram maiores 12 e $31 \%$ com a utilização de fibras torcidas, comparativamente.

$\mathrm{Na}$ Figura 55 foram plotados os valores de energia $T_{10}, T_{20}, T_{30}, T_{40}$ em função do deslocamento central dos painéis das séries HE 45/30 - 0,5\%, HE 45/30 - 1,0\%, HE 45/30 - 2,0\%, HE 80/60 - 2,0\% e TW 50/25 - 2,0\%. De maneira semelhante ao observado para as cargas residuais, verificou-se que a razão de aspecto das fibras tem influência expressiva na energia total absorvida (vide Figura 55b). 

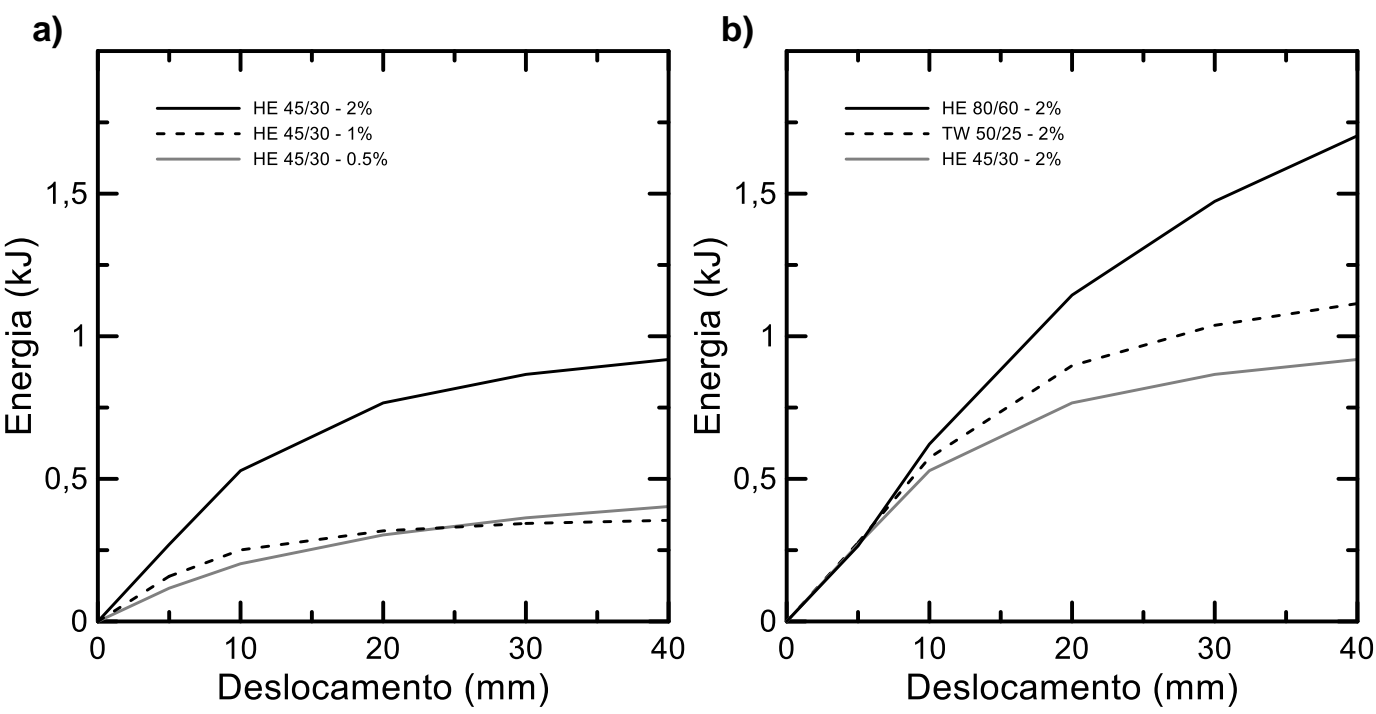

Figura 55 - Gráfico: a) energia-deslocamento médios à flexão de painéis circulares moldados com concreto autoadensável reforçado com fibras de razão de aspecto 45 e comprimento $30 \mathrm{~mm}$ nas frações volumétricas de $0,5,1,0$ e 2,0\%; b) comparativo de energia-deformação à flexão de painéis circulares moldados com concreto autoadensável reforçado com as diferentes de fibras utilizadas, na fração volumétrica de $2,0 \%$

Analisando a abertura de fissuras média em cada um dos ensaios, se observa que os gráficos foram quase assintóticos para os painéis reforçados nas frações volumétricas de fibras de 0,5 e 1,0\%.
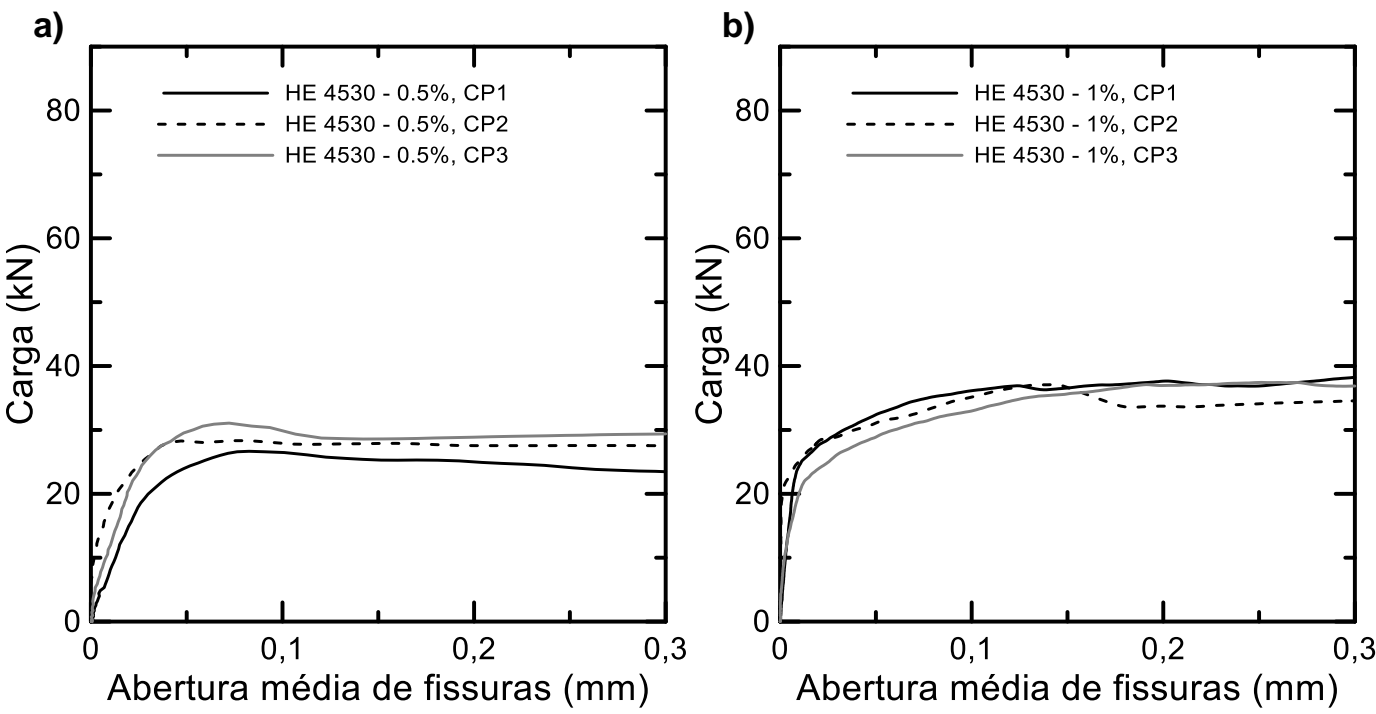

Figura 56 - Gráficos a-b) carga-abertura de fissuras à flexão de painéis circulares moldados com concreto autoadensável reforçado com fibras de aço providas de ganchos de razão de aspecto 45 e comprimento $30 \mathrm{~mm}$, nas frações volumétricas de $0,5,1,0 \%$, respectivamente 
Quando se utilizou a fração volumétrica de 2,0\%, as cargas necessárias para o progresso da abertura de fissuras foi crescente (vide Figura 57). Este fato se justifica pela recuperação de resistências motivada pelas pondes de fibras formadas entre fissuras, resultando em grande dissipação de energia e perda de linearidade observada na fase inicial nos gráficos (vide Figura 52 e Figura 53).
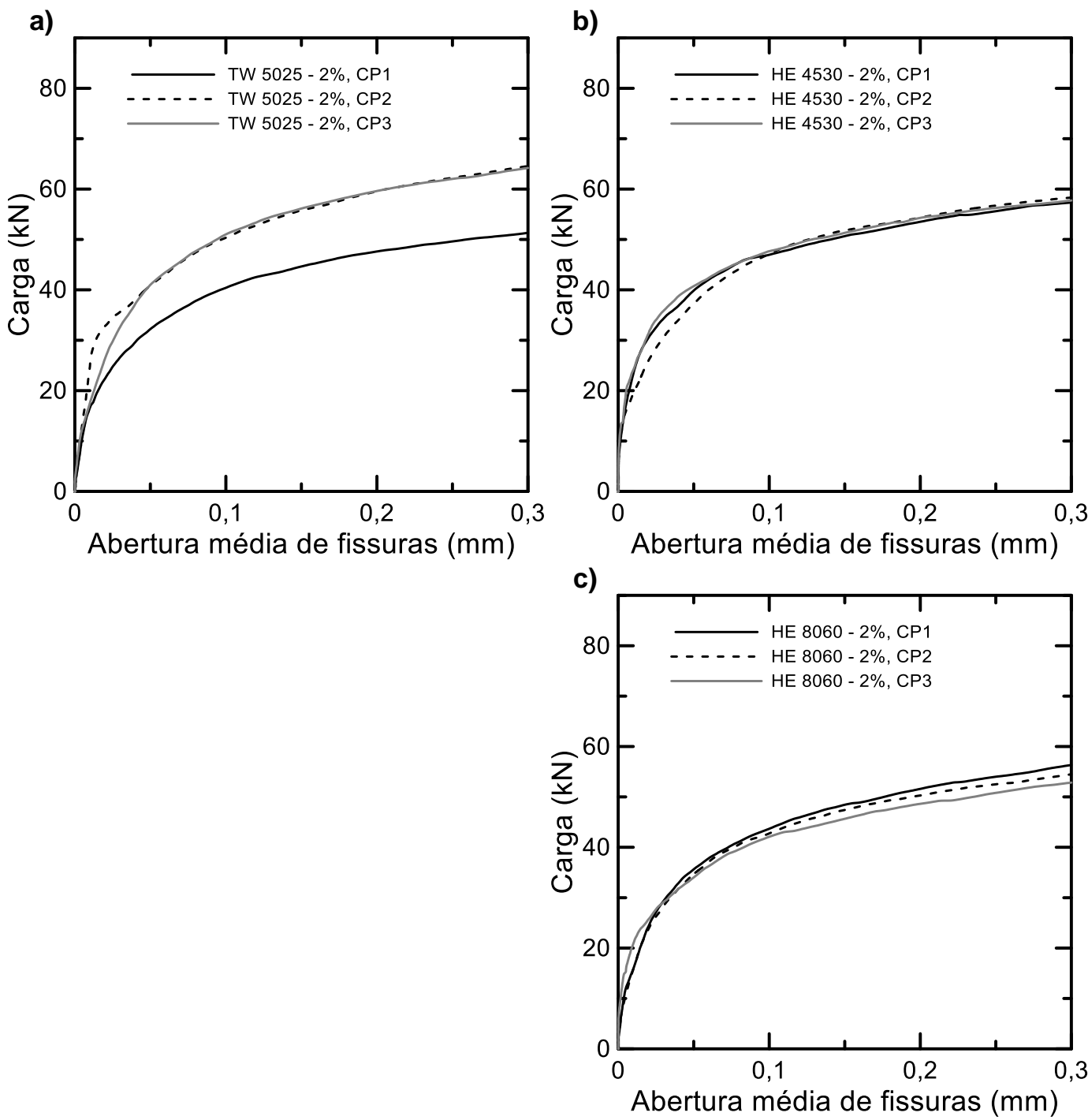

Figura 57 - Gráficos carga-abertura de fissuras à flexão de painéis circulares moldados com concreto autoadensável reforçado com a fração volumétrica de $2,0 \%$ de fibras de aço do tipo: a) torcidas de razão de aspecto 50 e comprimento $25 \mathrm{~mm}$; b) fibras com ganchos de razão de aspecto 45 e comprimento $30 \mathrm{~mm}$; c) fibras com ganchos de razão de aspecto 80 e comprimento $60 \mathrm{~mm}$ 
O padrão de fissuração observado nos ensaios de flexão em painéis circulares foi a abertura de uma ou três fissuras predominantes que se estendiam da região central dos corpos de prova até as regiões entre apoios (vide Figura 58, Figura 75, Figura 76 e Figura 77). Foi observado também, um segundo modo de ruptura anômalo (vide Figura 58a contra Figura 58b).

a)

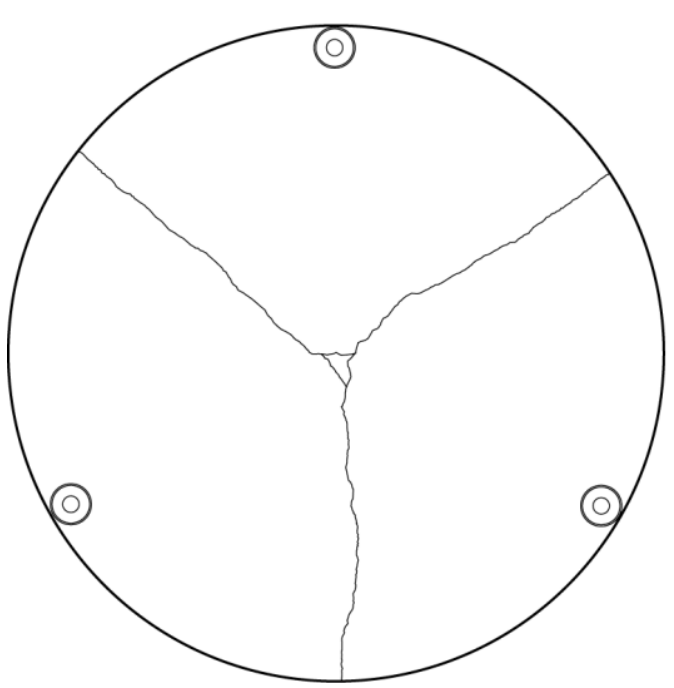

b) RUPTURA MODO॥

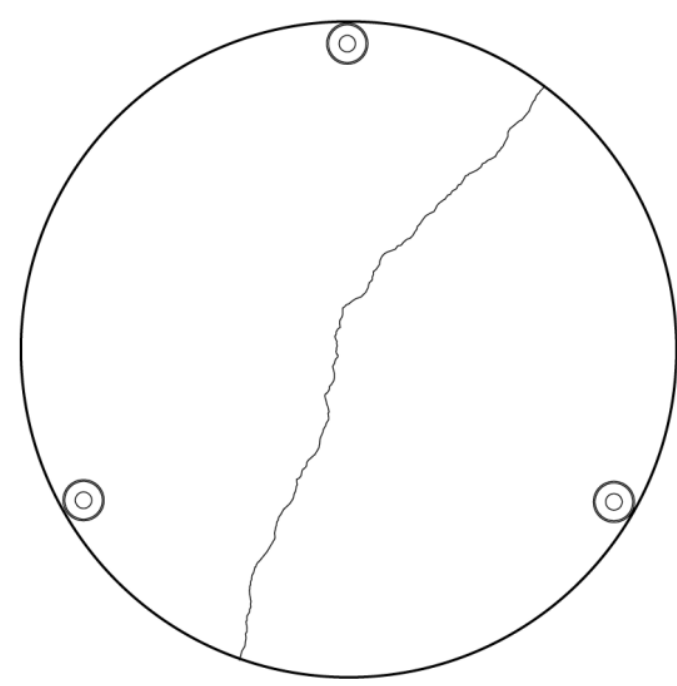

Figura 58 - llustração: a) do modo de ruptura esperado (ASTM C 1550 [3]); b) do outro modo de ruptura observado nos ensaios de flexão em painéis circulares

\section{3}

\section{Ensaios estruturais}

\subsection{1}

Ensaios em vigas curtas armadas

Este item se destina à avaliação do desempenho à flexão e de vigas de concreto armado agrupadas em seis séries de corpos de prova. Três delas foram concretadas com concreto autoadensável de referência e as demais, com o concreto autoadensável reforçado com fibras HE 45/30, na fração volumétrica de $2,0 \%$. Todos os ensaios foram realizados conforme procedimento experimental descrito no item 3.4.3.1, cujas cargas de ensaio foram investigadas e relacionadas com as deflexões.

Sabe-se, que a falha por tração dos concretos ocorre em deformações significativamente menores do que a do ponto de escoamento das barras de aço e o concreto fissura antes mesmo que Ihe seja transferida carga significante. Por 
isto, também se observaram as aberturas de fissuras para deflexões específicas, cujo atendimento ao estado limite de serviço especificado foi observado. Por fim, as cargas máximas obtidas nos ensaios foram comparadas com as resistências calculadas para o estado limite último.

Sobre o ponto de vista estrutural, observou-se por meio da Figura 59a e Figura 59b, que a capacidade de carga máxima das vigas foi aumentada ao passo que se aumentou a taxa geométrica de armaduras e se empregou reforço fibroso. Do ponto de vista da capacidade de carga última obtida nos ensaios, a viga reforçada com fibras de aço que tinha taxa geométrica de armaduras de $0,45 \%$ teve carga última equivalente à obtida na viga sem reforço com taxa de $0,70 \%$. Este fato indica que a inclusão de 2,0\% de fibras com ganchos de comprimento $30 \mathrm{~mm}$ equivaleu-se, do ponto de vista da resistência última, à taxa geométrica de armadura de 0,25\%.

a)

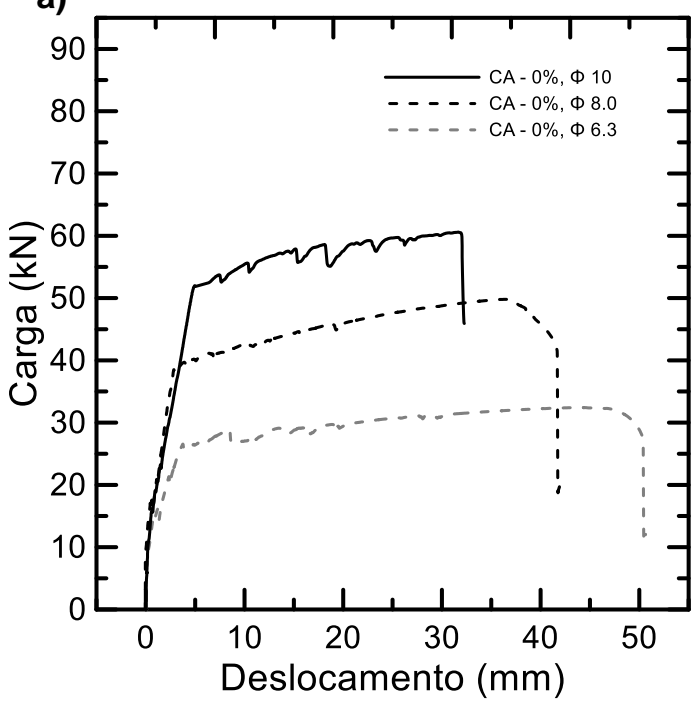

b)

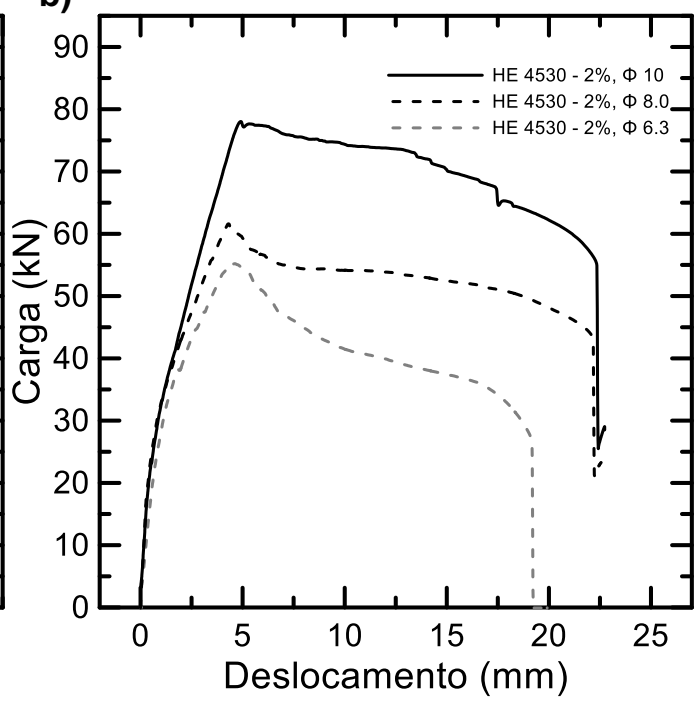

Figura 59 - Gráficos carga-deslocamento à flexão de vigas armadas com pares barras de aço de 6.3, 8.0 e $10 \mathrm{~mm}$ e moldadas com: a) matriz de concreto autoadensável; b) concreto autoadensável reforçado com fibras de aço com ganchos de razão de aspecto 45 e comprimento $30 \mathrm{~mm}$, na fração volumétrica de $2,0 \%$

Ao se comparar duas vigas com mesma taxa de armadura, uma com reforço e a outra sem, observa-se que as cargas máximas obtidas nos ensaios correspondem à deflexões de menores magnitudes (vide Figura 59a e Figura 59b). Objetivando explicar estes efeitos, utilizaram-se os gráficos momentocurvatura, cujo comportamento geral foi descrito por Grimaldi et al. [113] (vide 
Figura 60c). Segundo Grimaldi et al. [113], depois da fase elástica inicial (OA) ocorre a fissuração do concreto e há deslizamento entre os materiais. Em seguida há redistribuição das tensões e deformações, no qual os valores relacionados com uma única seção perdem importância e se torna necessário se referir aos valores médios ao longo do elemento. Conforme se incrementa os níveis de deformação nas vigas, as barras de aço se alongam cada vez mais $(A B)$ até alcançarem seu ponto de escoamento na seção onde passou a fissura (B). Impondo maiores níveis de deslocamentos (ou cargas), as deformações plásticas ao longo do elemento crescem (BC) até que se alcance a condição limite última por compressão do concreto ou por deformação excessiva das armaduras.

a)

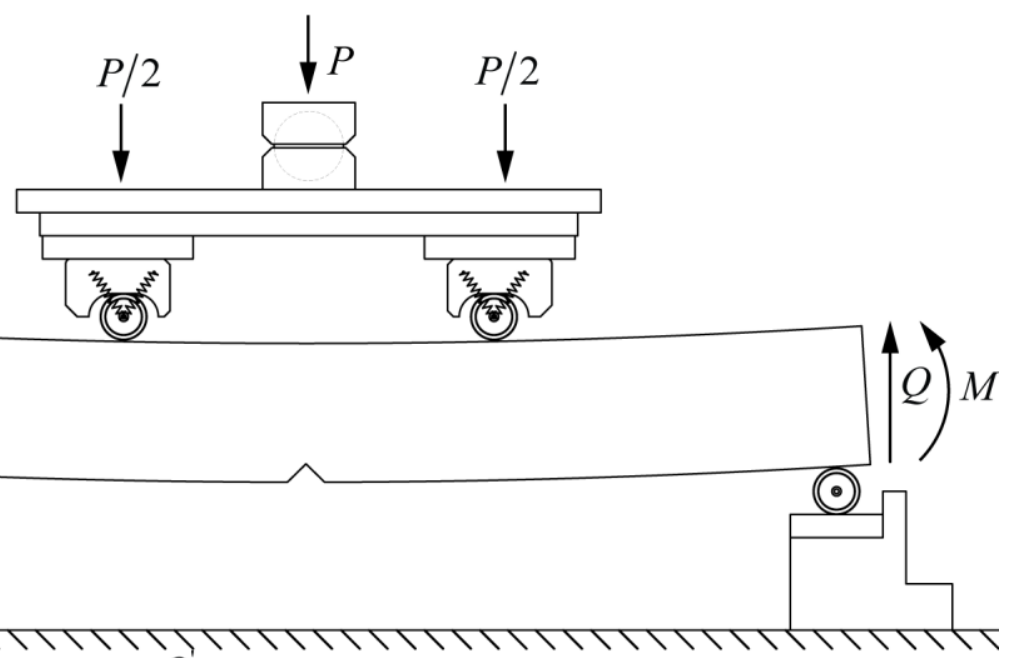

b)

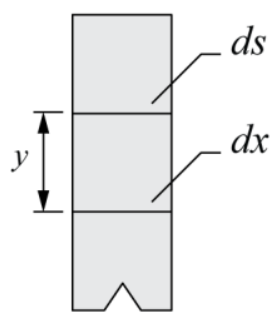

antes da deformação

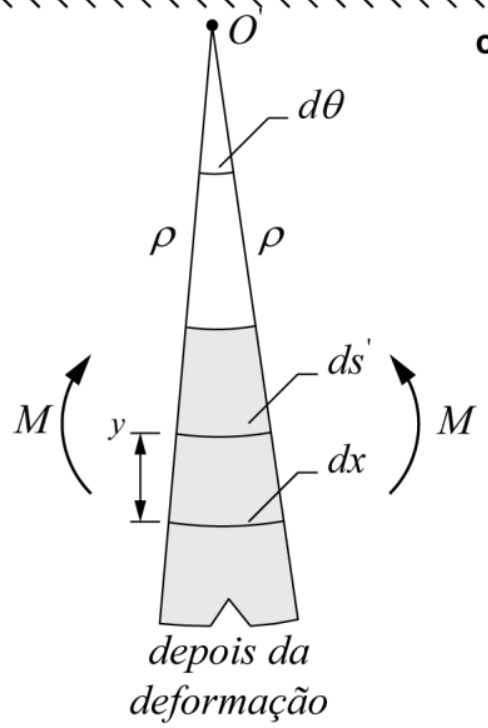

c)

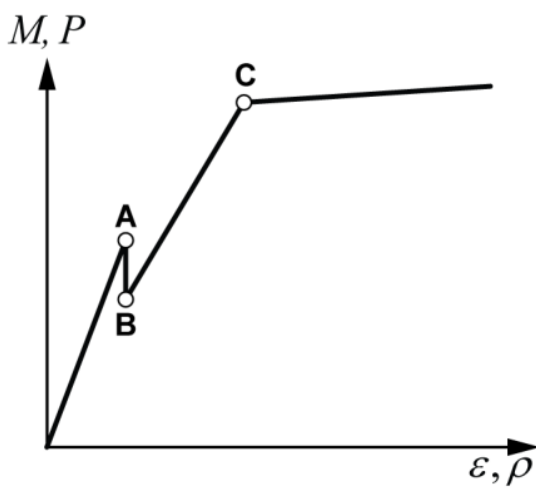

Figura 60 - llustração: a) do detalhe da viga armada sob flexão; b) do modelo utilizado para cálculo dos gráficos momento-curvatura; c) do gráfico momentocurvatura típico 
Para cálculo da relação momento-curvatura utilizou-se as expressões teóricas da resistência dos materiais que relacionam as deformações na região central de vigas. O modelo considera que o eixo $x$ estende-se na direção positiva para a direita, ao longo do eixo longitudinal do trecho inicialmente reto da viga, que contém o elemento diferencial $d x$ (vide Figura 60b). Ao se aplicar a carga $P$, o momento fletor interno $M$ deforma o elemento de viga e as seções transversais formam o ângulo $d \theta$ entre si. Em consequência o elemento $d x$ se torna um arco que intercepta o eixo neutro, representando uma porção da linha elástica entre as seções transversais. A distância do centro de curvatura $O$ até $d x$ é o raio de curvatura $\rho$. Qualquer ponto distante de $d x$ está sujeito à uma deformação normal, exceto $d x$, que passa na linha neutra da viga. Um elemento distante de $y$ em relação à linha neutra é um arco de comprimento $d s$ cuja deformação resulta em:

$$
\varepsilon_{c}=\left(d s^{\prime}-d s\right) / d s
$$

$\mathrm{O}$ arco $d s$ por sua vez, pode ser relacionado com o raio de curvatura $\rho$ e o ângulo $d \theta$ pela expressão:

$$
d s=d x=\rho \cdot d \theta
$$

O $\operatorname{arco} d s$ depois da deformação assume o comprimento $d s^{\prime}$, e tem raio de curvatura $\rho-y$. Da mesma maneira que na eq. (4.2), tem-se:

$$
d s^{\prime}=(\rho-y) d \theta
$$

Utilizando as equações 4.1, 4.2 e 4.9, resulta-se na relação da curvatura (vide eq. (4.4)) com as deformações do elemento de viga, cuja posição da linha neutra foi estimada por meio dos dados de ensaio na eq. (4.5) para plotar os gráficos momento-curvatura apresentados na Figura 61.

$$
\begin{gathered}
\frac{1}{\rho}=\frac{-\varepsilon_{c}}{y} \\
y=\frac{\varepsilon_{c} \cdot h}{\varepsilon_{c}+\left|\varepsilon_{t}\right|}
\end{gathered}
$$


Onde,

$\rho=$ raio de curvatura de um ponto qualquer sobre a linha elástica;

$\frac{1}{\rho} \quad=0$ inverso do raio de curvatura denomina-se "curvatura";

$\varepsilon_{c} \quad=$ deformação de compressão determinada experimentalmente;

$y \quad$ = altura da linha neutra até a fibra superior das vigas de concreto armado determinada experimentalmente

a)

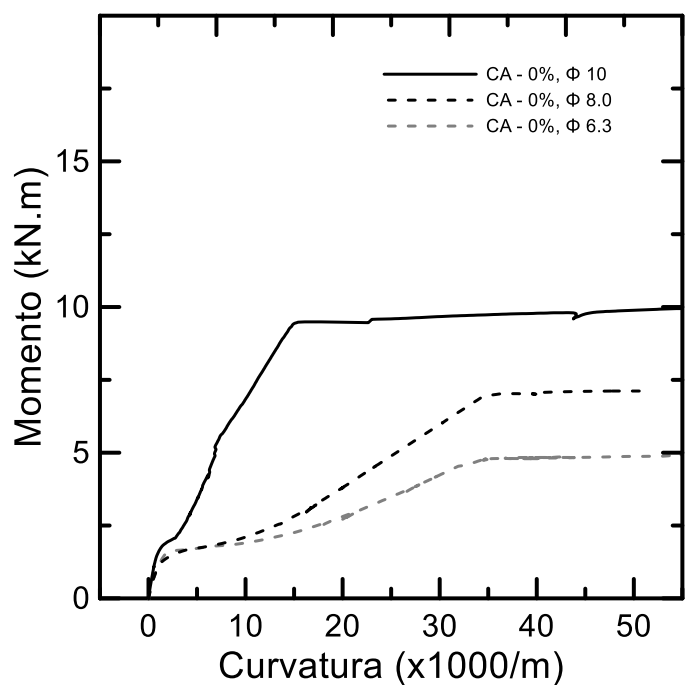

c)

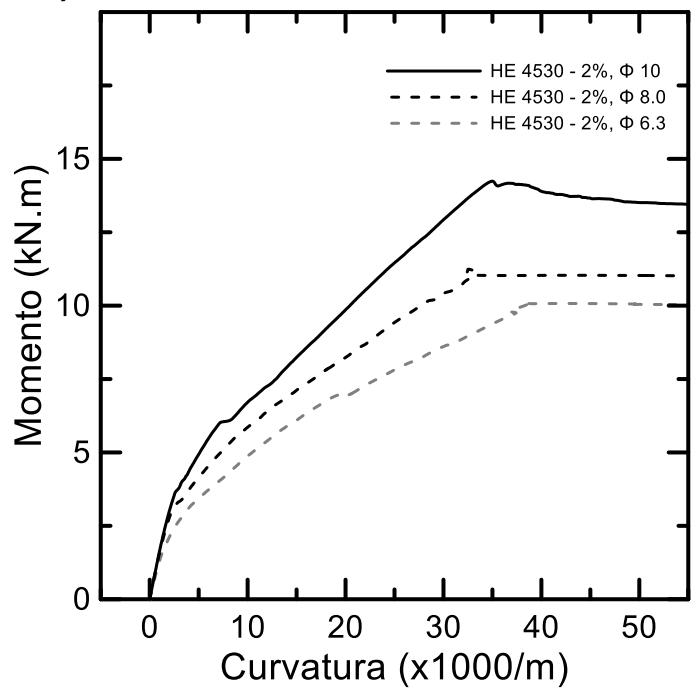

b)

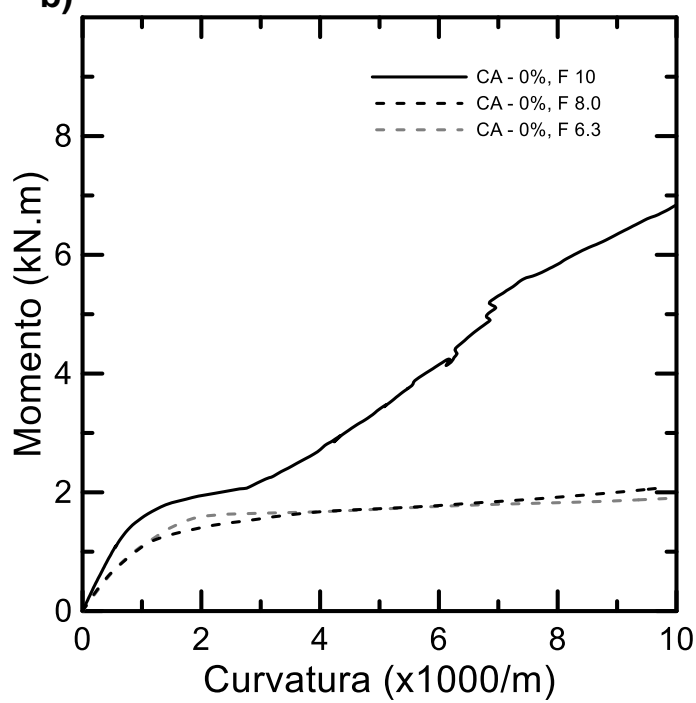

d)

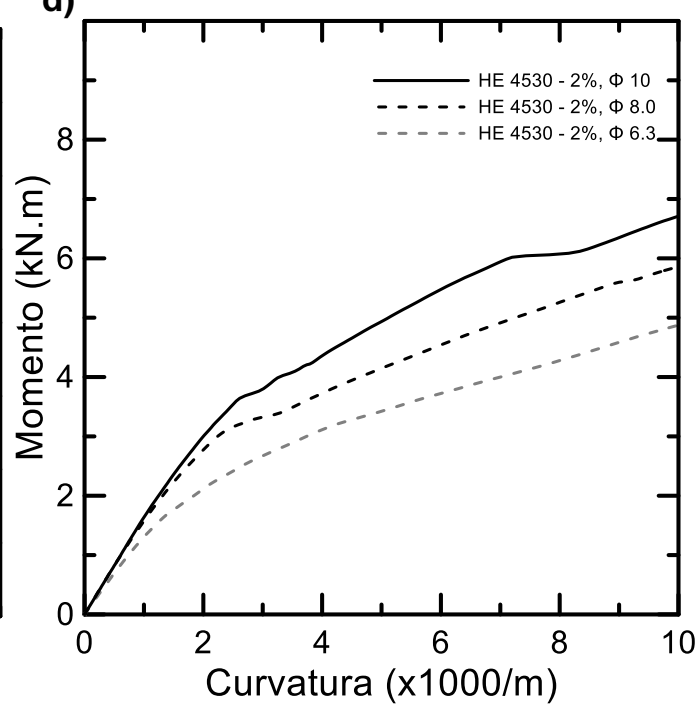

Figura 61 - Gráfico: a) momento-curvatura de vigas moldadas com a matriz de concreto autoadensável e armadas com pares de barras de 6,3, 8,0 e 10,0 mm; b) do trecho inicial da curva "a"; c) momento-curvatura de vigas armadas e reforçadas com concreto autoadensável contendo a fração volumétrica de $2,0 \%$ de fibras com ganchos de comprimento $30 \mathrm{~mm}$ e razão de aspecto 45; d) do trecho inicial da curva "c" 
Observou-se por meio da análise da Figura 61 que, a viga armada e reforçada (2 $\Phi 10 \mathrm{~mm}$ ) apresentou menor curvatura com relação à viga sem reforço (vide Figura 61a contra Figura 61c). Foi mencionado que, ao se comparar duas vigas de mesma taxa de armadura, a primeira com o reforço fibroso e a segunda sem, observa-se menores níveis de deflexão. Este fato se justifica pelo aumento de rigidez à flexão observado nos gráficos da Figura 62 , que mostram que para estágios iniciais de carregamento, as vigas formadas por SCCs tiveram sua rigidez reduzida de forma intensa, enquanto que as vigas formadas por SFRSCCs tiveram redução suave - mesmo para níveis de carga dobrados. Cada um dos pontos de rigidez à flexão observados nos gráficos da Figura 62 corresponde à um módulo secante inicial dos gráficos momentocurvatura (vide Figura 61).

a)

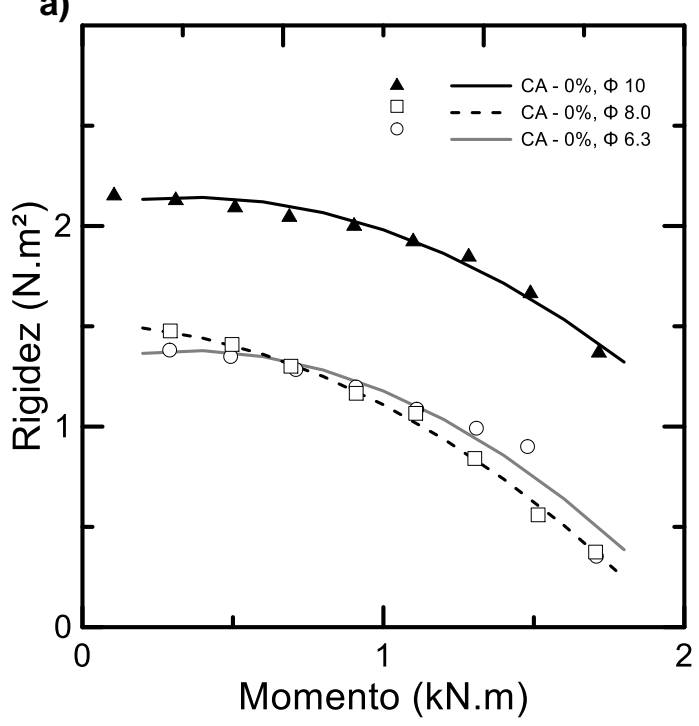

b)

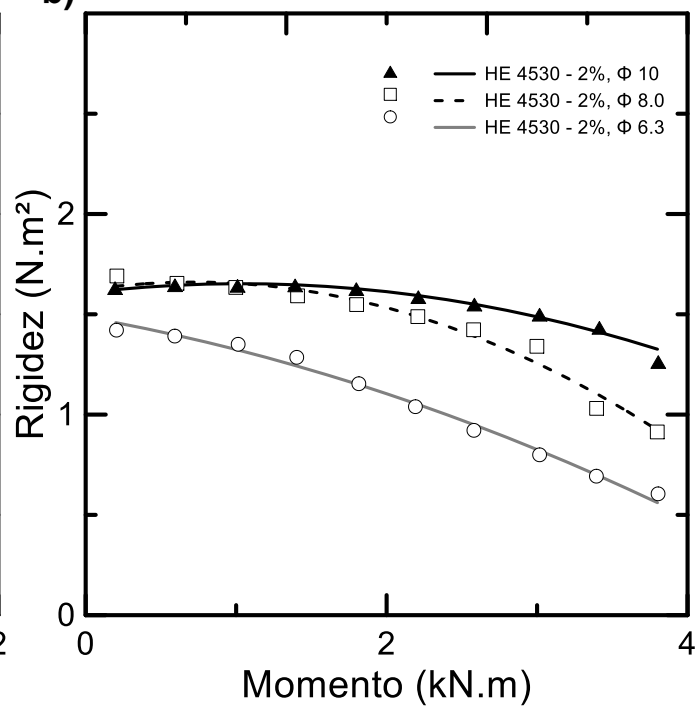

Figura 62 - Gráficos rigidez-momento de vigas armadas com pares barras de aço de 6.3, 8.0 e $10 \mathrm{~mm}$ e moldadas com: a) matriz de concreto autoadensável; b) concreto autoadensável reforçado com fibras de aço com ganchos de razão de aspecto 45 e comprimento $30 \mathrm{~mm}$, na fração volumétrica de $2,0 \%$

Para efeito de verificação das condições de serviço, a NBR 6118 [114] orienta utilizar como referência o momento de primeira fissura. Este momento corresponde à região elástica no qual a fibra inferior da viga alcança a resistência última à tração direta. Para efeito de cálculo da resistência à tração dos concretos utilizaram-se os resultados de tração direta obtidos na seção 4.1.3 e, para cálculo do momento de primeira fissura utilizou-se a expressão da NBR 6118 [114] (vide eq. (4.6)). A resistência à tração foi calculada por sua vez, utilizando-se o valor médio de resistência do concreto fibroso com fração 
volumétrica de 2,0 \% (4,54 MPa), o desvio padrão (0,38 MPa) e o quantil de $5 \%$, resultando na resistência de $3,91 \mathrm{MPa}$.

$$
M_{r}=\frac{f_{c t} \cdot I_{c}}{y_{t}}
$$

Onde,

$M_{r}=$ momento de fissuração;

$f_{c t}=$ resistência do concreto à tração direta;

$I_{c} \quad=$ momento de inércia da seção bruta;

$y_{t} \quad=$ distância do centro de gravidade da seção à fibra mais tracionada.

Entrando com a resistência à tração e os parâmetros geométricos da seção da viga na (eq. (4.6)), resulta-se no momento de primeira fissura de 2,20 kNm, cuja carga de ensaio correspondente é 11,73 kN. Espera-se, contudo, que a carga de iminência da primeira fissura das vigas ocorra em estágios preliminares de carregamento. A fim de se observar o padrão de fissuração e de esclarecer as dúvidas com relação ao surgimento de fissuras nos estágios preliminares de carga, foram utilizados os mapas de deformações gerados pelo sistema de correlação digital de imagens.

A Figura 63a representa as deformações que ocorreram em uma única linha que passa na altura das barras de aço na região monitorada de $\pm 200 \mathrm{~mm}$, para diversos estágios de cargas e deflexões múltiplas do comprimento útil das vigas (de L/8000 até L/250). Pela análise da Figura 63b, observa-se que o surgimento da primeira fissura da viga armada com um par de barras de $10,0 \mathrm{~mm}$ e reforçada com 2,0\% de fibras ocorreu antes da deflexão L/2000 $(0,6 \mathrm{~mm}) \mathrm{e}, \mathrm{com}$ momento fletor corresponde à aproximadamente duas vezes ao de primeira fissura $\left(M \approx 2 M_{r}\right)$. Conforme os deslocamentos foram sendo impostos pelo atuador hidráulico, observou-se por meio da análise das mesmas figuras o surgimento de pares de novas fissuras posicionadas à direita e à esquerda da fissura principal (vide Figura 63a e Figura 63b). 
a)

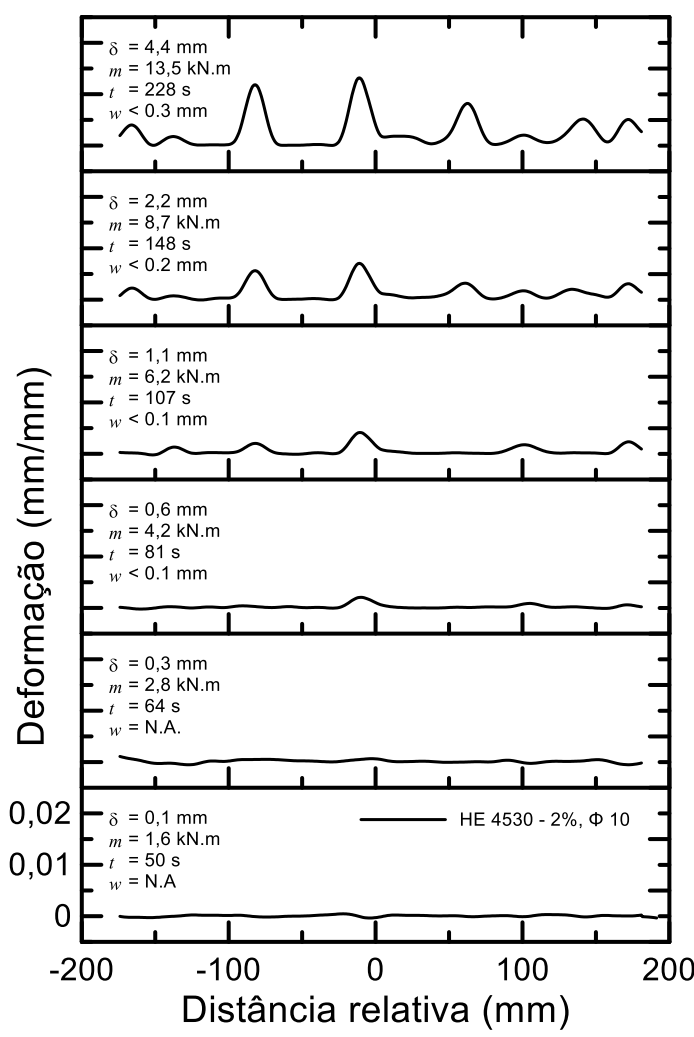

b)

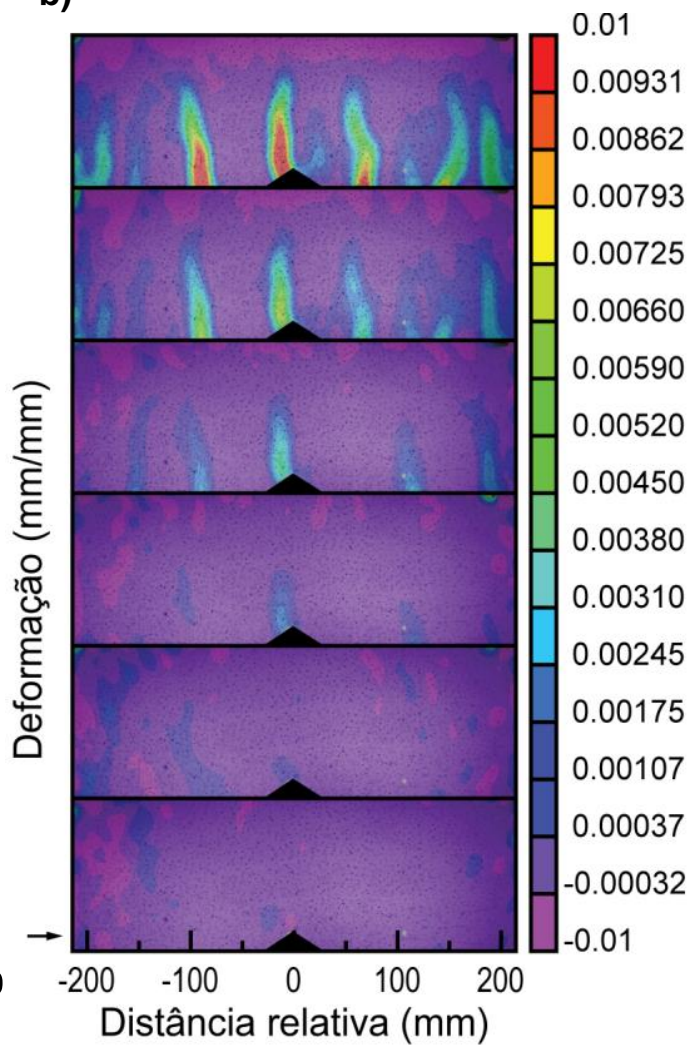

Figura 63 - Gráficos deformação-distância de vigas armadas com um par de barras de $10 \mathrm{~mm}$ para: a) uma linha que passa na altura do eixo das barras de aço; b) a região inteira monitorada pelo sistema de correlação digital de imagens (DIC)

Ao se comparar duas vigas com mesma taxa de armadura, a primeira concretada com o concreto autoadensável de referência e a segunda reforçada com concreto autoadensável com 2,0 \% de fibras de aço HE 45/30 observou-se que, para o mesmo nível de deflexão, as vigas reforçadas exibiram menor número e abertura de fissuras (vide Figura 64 e Figura 65). Este fato é resultado da resposta mais rígida à flexão observada nos gráficos momento-curvatura (vide Figura 61). 
a)

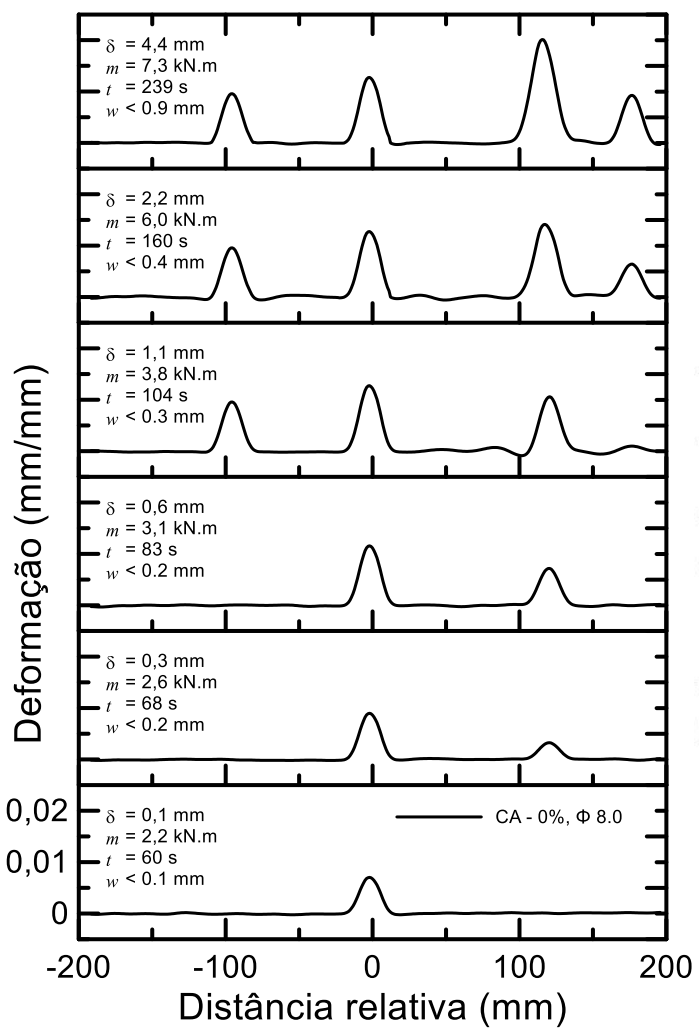

c)

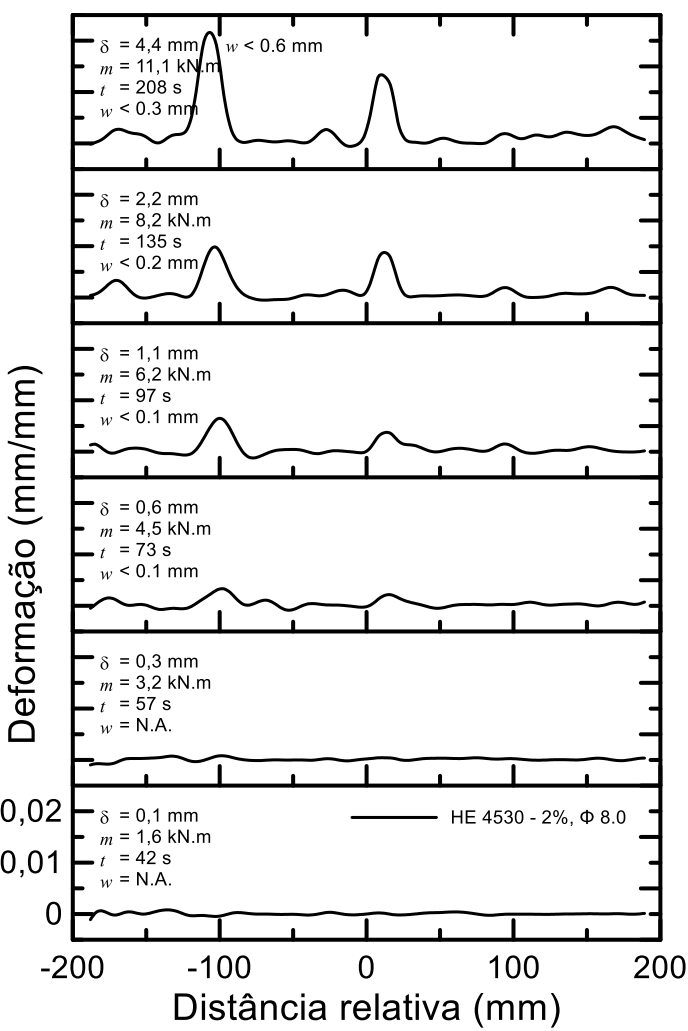

b)

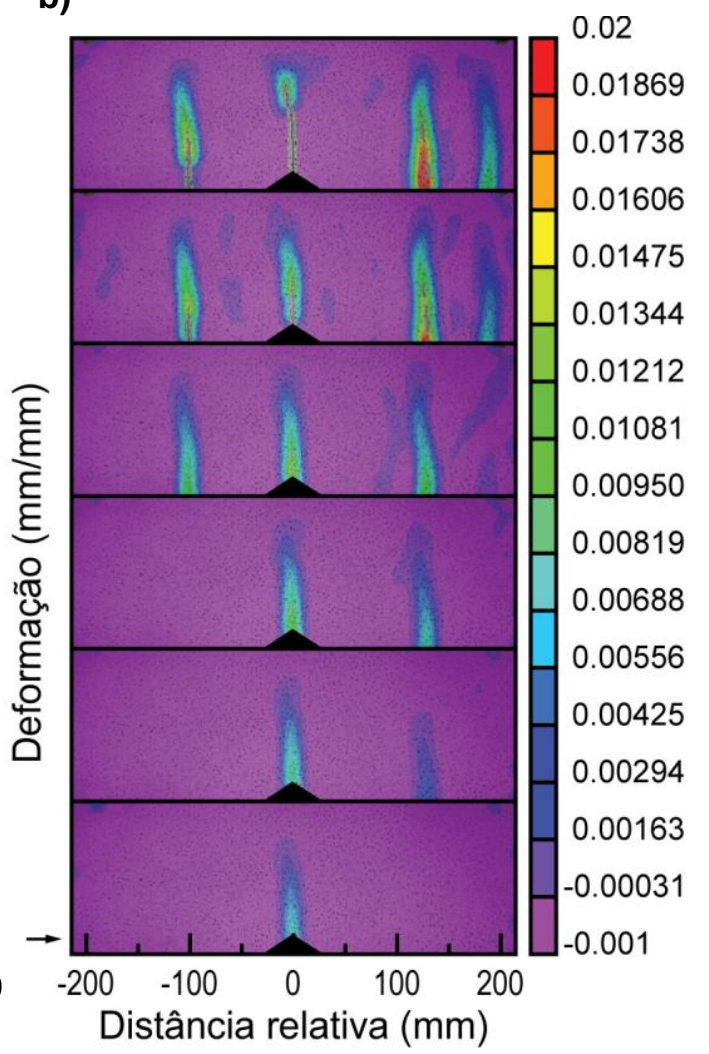

d)

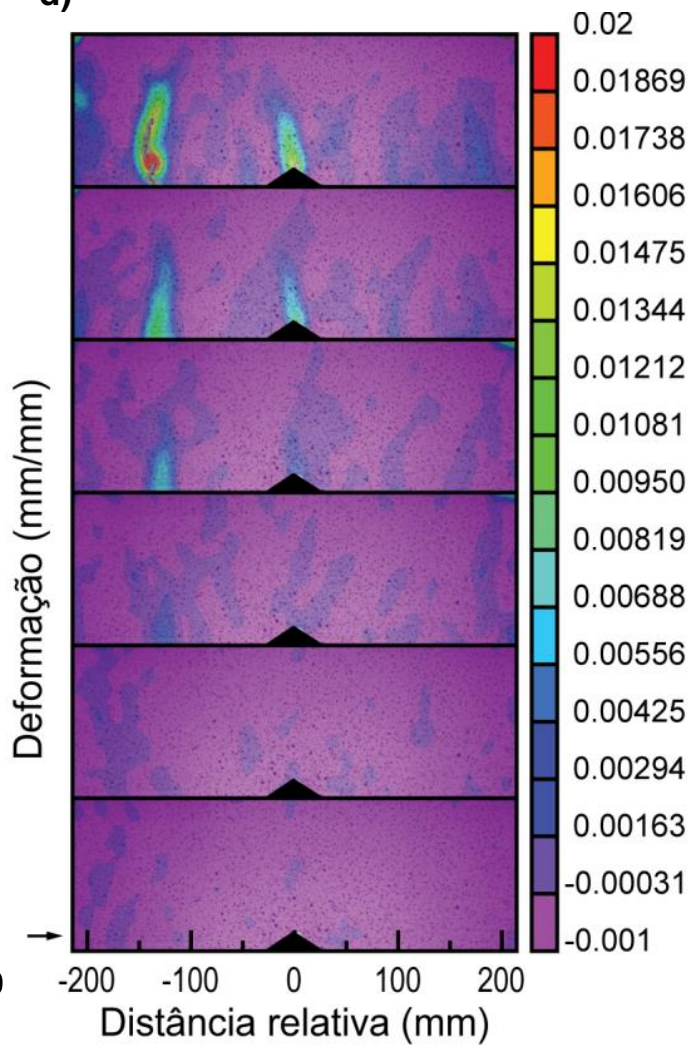

Figura 64 - Gráficos comparativos de deformação-distância de vigas armadas com um par de barras de $8.0 \mathrm{~mm}$ : a-b) sem reforço fibroso; b-d) com reforço de 2,0 \% de fibras de aço de aspecto 45 e comprimento $30 \mathrm{~mm}$ 
a)

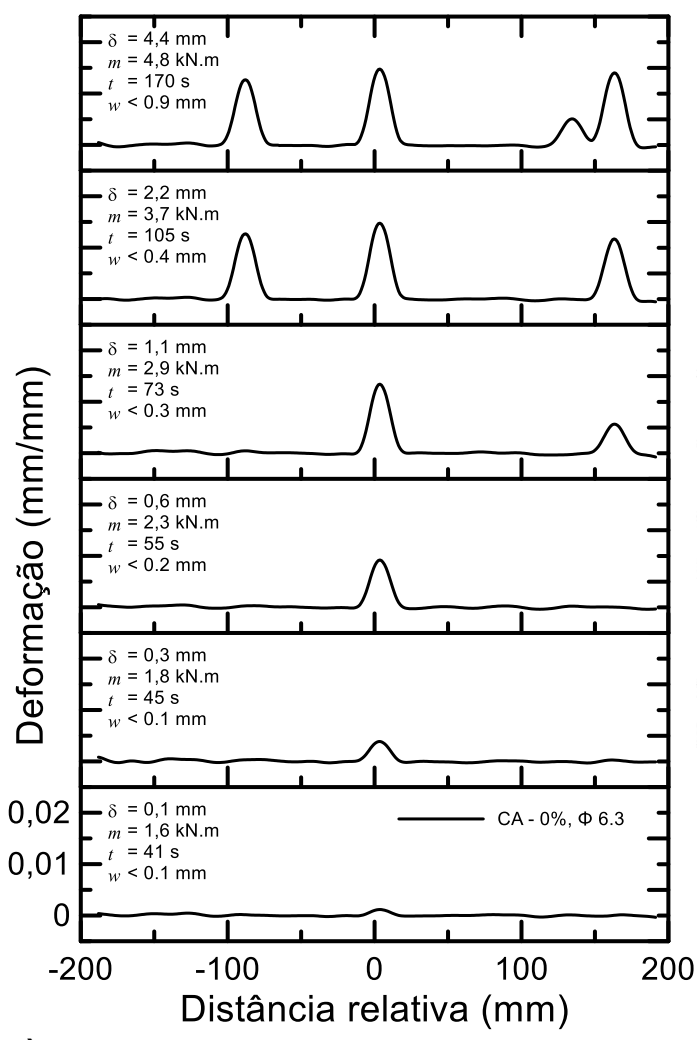

c)

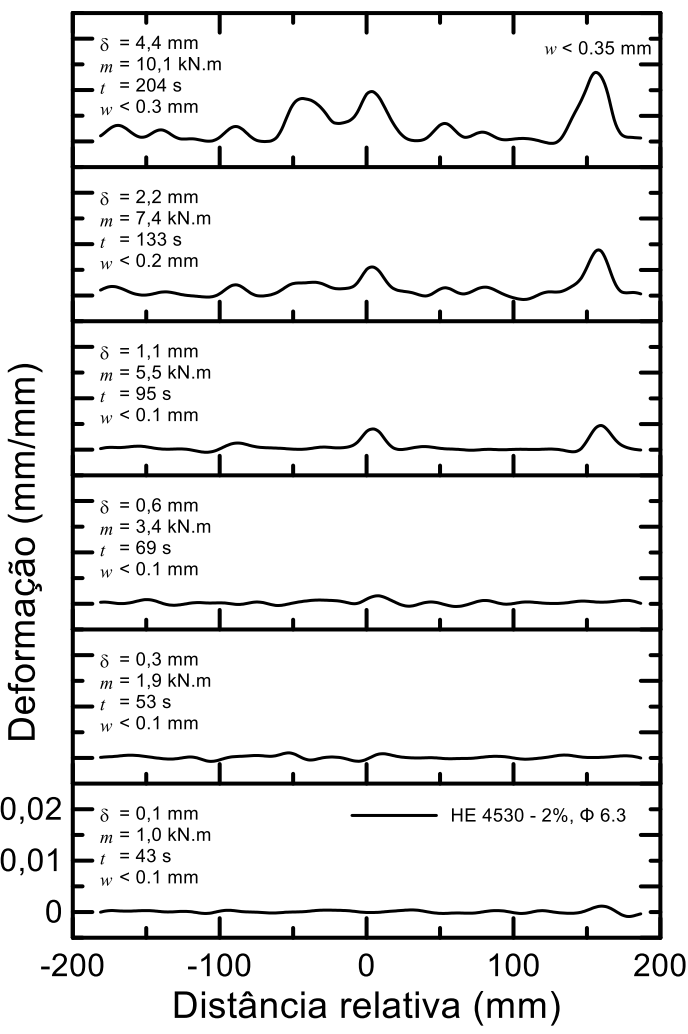

b)

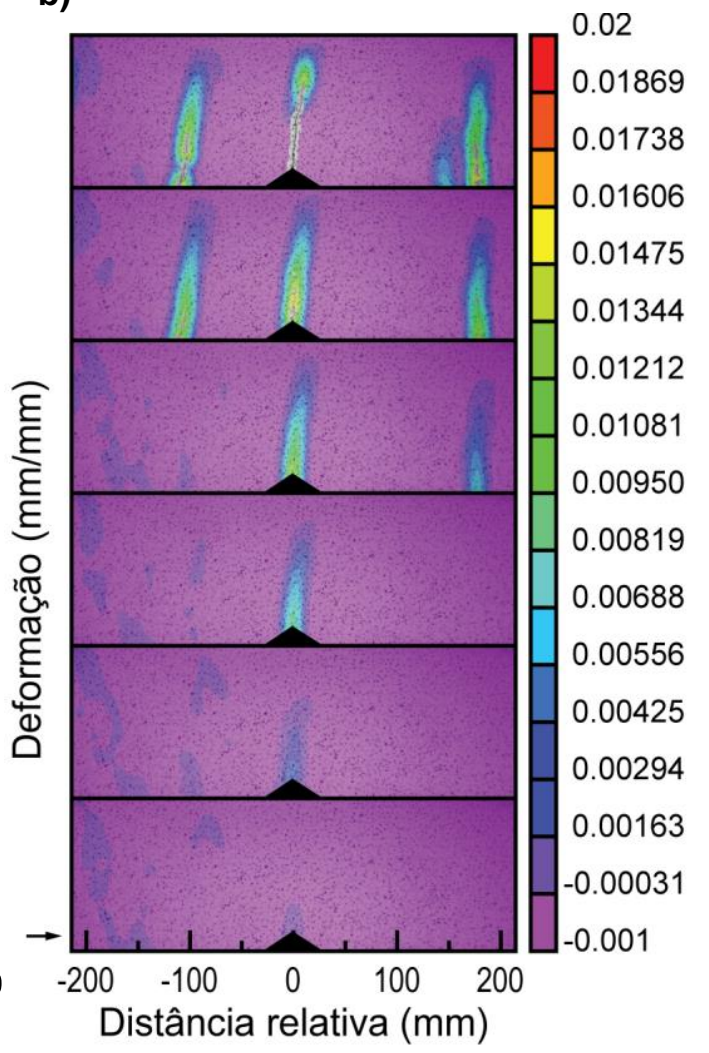

d)

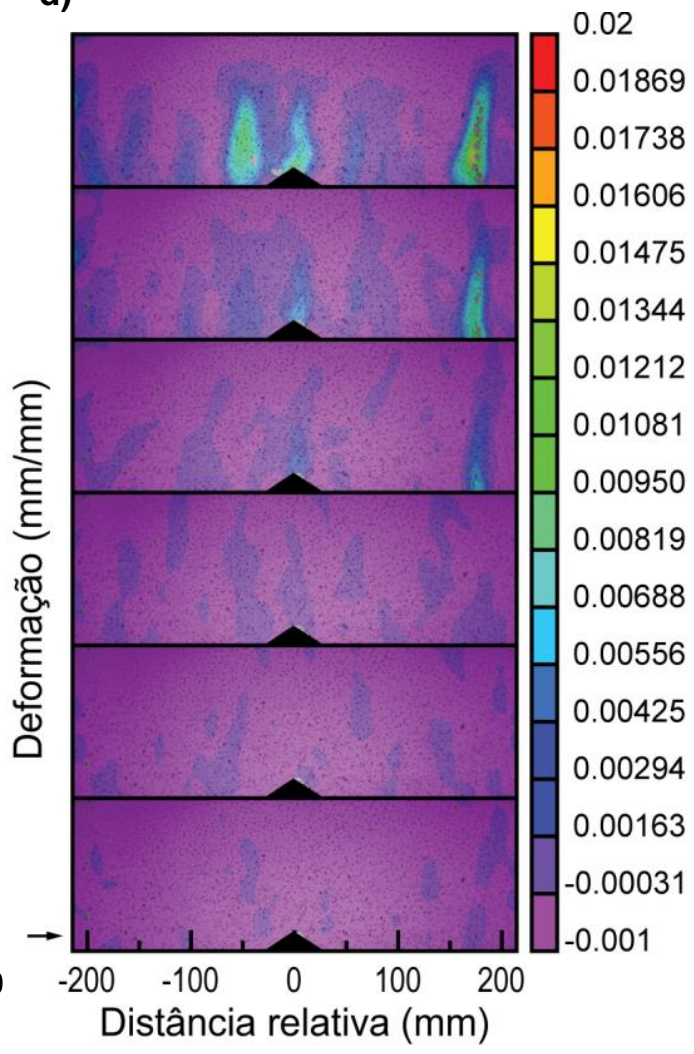

Figura 65 - Gráficos comparativos de deformação-distância de vigas armadas com um par de barras de $6.3 \mathrm{~mm}$ : a-b) sem reforço fibroso; b-d) com reforço de 2,0 \% de fibras de aço de aspecto 45 e comprimento $30 \mathrm{~mm}$ 
A Tabela 17 resume os resultados obtidas nos ensaios em função da abertura de fissuras obtidas com auxilio do DIC, cuja definição das seguintes variáveis se mostrou necessária para sua análise:

$P_{0,1} \quad=$ carga que corresponde à abertura de fissura menor ou igual à $0,1 \mathrm{~mm}$;

$\delta_{0,1}=$ deflexão correspondente à abertura de fissura menor ou igual à 0,1 mm;

$P_{0,2}=$ carga que corresponde à abertura de fissura menor ou igual à $0,2 \mathrm{~mm}$;

$\delta_{0,2}=$ deflexão correspondente à abertura de fissura menor ou igual à $0,2 \mathrm{~mm}$;

$P_{0,3}=$ carga que corresponde à abertura de fissura menor ou igual à $0,3 \mathrm{~mm}$;

$\delta_{0,3}=$ deflexão correspondente à abertura de fissura menor ou igual à $0,3 \mathrm{~mm}$;

$P_{\text {máx }}=$ carga máxima obtida nos ensaios;

$\delta_{\text {máx }}=$ deflexão máxima obtida nos ensaios.

Tabela 17 - Valores característicos individuais à flexão de vigas

Valores característicos individuais à flexão de vigas

Resultados de carga à primeira fissura, máxima e de aberturas de

fissuras de vigas armadas e de vigas armadas e reforçadas com fibras de aço

valores absolutos

\begin{tabular}{|lcccccccc|}
\hline $\begin{array}{l}\text { Amostra / corpo-de- } \\
\text { prova }\end{array}$ & $\begin{array}{c}P_{0.1} \\
\mathrm{kN}\end{array}$ & $\begin{array}{c}\delta_{0.1} \\
\mathrm{~mm}\end{array}$ & $\begin{array}{c}P_{0.2} \\
\mathrm{kN}\end{array}$ & $\begin{array}{c}\delta_{0.2} \\
\mathrm{~mm}\end{array}$ & $\begin{array}{c}P_{0.3} \\
\mathrm{kN}\end{array}$ & $\begin{array}{c}\delta_{0.3} \\
\mathrm{~mm}\end{array}$ & $\begin{array}{c}P_{\text {máx }} \\
\mathrm{kN}\end{array}$ & $\begin{array}{c}\delta_{\text {máx }} \\
\mathrm{mm}\end{array}$ \\
\hline $\mathrm{CA}-0 \%, 6.3 \mathrm{~mm}$ & 10,8 & 0,400 & 15,2 & 1,022 & 20,1 & 2,131 & 32,4 & 44,5 \\
\hline $\mathrm{CA}-2 \%, 6.3 \mathrm{~mm}$ & 32,0 & 1,235 & 47,0 & 3,045 & 55,3 & 4,433 & 55,4 & 04,5 \\
\hline $\mathrm{CA}-0 \%, 8.0 \mathrm{~mm}$ & 11,4 & 0,107 & 17,5 & 0,830 & 30,3 & 1,990 & 49,8 & 36,3 \\
\hline $\mathrm{CA}-2 \%, 8.0 \mathrm{~mm}$ & 36,9 & 1,363 & 45,6 & 2,285 & 56,2 & 3,559 & 61,6 & 04,3 \\
\hline $\mathrm{CA}-0 \%, 10.0 \mathrm{~mm}$ & 16,9 & 0,781 & 29,2 & 2,203 & 38,7 & 3,368 & 60,6 & 31,6 \\
\hline $\mathrm{CA}-2 \%, 10.0 \mathrm{~mm}$ & 36,9 & 1,313 & 60,9 & 3,243 & 75,4 & 4,528 & 78,0 & 04,9 \\
\hline
\end{tabular}

Obs.: subscrito "0,1" para a abertura de fissuras menores ou iguais à $0,1 \mathrm{~mm}$.

Por meio da análise da Tabela 17 observa-se que os incrementos de carga promovidos pelo reforço fibroso variam de 100 a $200 \%$ para aberturas de fissuras menores que $0,1 \mathrm{~mm}$, sendo esperado então, que para que ocorra uma fissura de mesma magnitude, seja necessário uma carga na ordem de 2 a 3 vezes àquela aplicada na viga de referência. Observa-se ainda pela Tabela 17, que estes incrementos foram ainda mais expressivos nos pontos correspondentes às aberturas de fissuras de 0,2 e 0,3 mm. 


\subsection{2 \\ Cálculo da capacidade de carga das vigas armadas e reforçadas}

A carga residual de tração dos SFRCs é comumente determinada a partir dos resultados dos ensaios de CMOD (Crack Mouth Opening Displacement, vide EN 14651 [98]), no qual são feitas duas considerações distintas para estabelecer as leis constitutivas dos concreto (vide Figura 66): a primeira relaciona as resistências residuais de tração em função da abertura de fissuras, que é o caso do Model Code [66]; a segunda relaciona as tensões residuais de tração em função da deformação dos materiais, que é o caso das abordagens da norma ACI 544.4R [40] e RILEM TC 162-TDF [97].

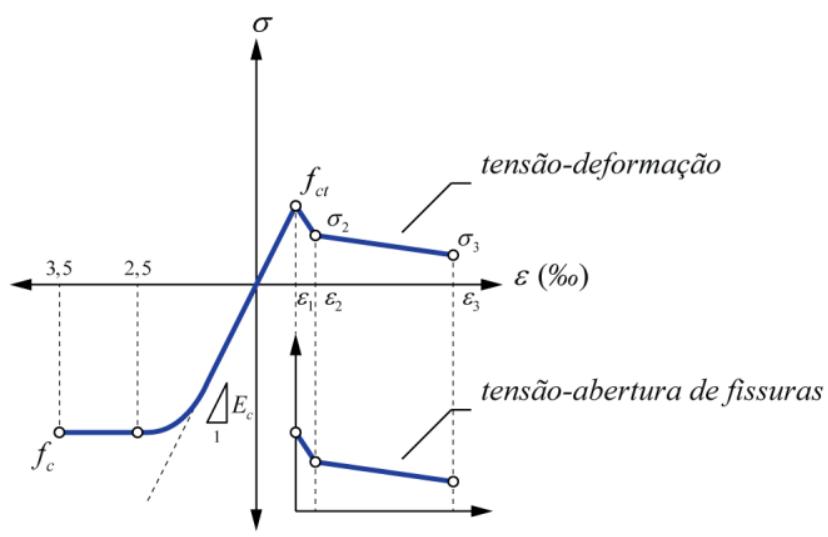

Figura 66 - Leis constitutivas dos SFRCs em termos de $\sigma-\varepsilon$ e $\sigma-w$

A norma $\mathrm{ACl}$ 544.4R [40] além de propor uma relação empírica para determinação da resistência residual à tração, inclui um método de cálculo que se baseia no método desenvolvido por Henager e Doherty apud ACI 544.4R [40], que é muito semelhante ao método de cálculo para o estado último de serviço proposto na $\mathrm{ACI}$ 318. O princípio básico de cálculo está na consideração de uma parcela da resistência à tração do concreto fibroso que é adicionada àquela promovida pelas barras de aço, obtendo-se assim o momento último de cálculo (vide Figura 67). O momento resistente calculado por meio das equações 4.7, 4.8, 4.9 e 4.10 dependem das considerações feitas sobre as resistências características dos materiais, cujas deformações máximas admissíveis para o aço e concreto são consideradas em $3 \%$ e 2 \%, respectivamente. 


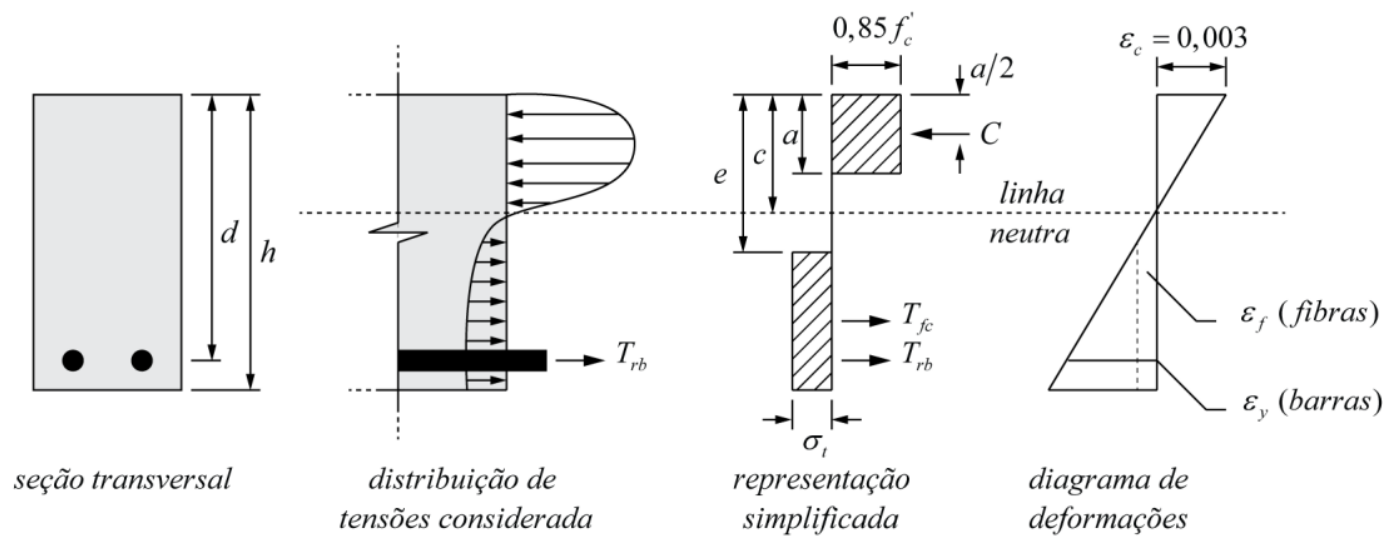

Figura 67 - Considerações de projeto para análise de vigas concreto armado contendo fibras de aço; adaptado da ACI 544.4R [40]

$$
\begin{gathered}
c=\frac{0,003 \cdot d}{\varepsilon_{y}+0,003} \\
e=\left(\varepsilon_{s}+0,003\right) \cdot \frac{c}{0,003} \\
\sigma_{t}=0,00772 \cdot \ell_{f} / d_{f} \cdot V_{f} \cdot F_{b e} \\
M_{n}=A_{s} \cdot f_{y}\left(d-\frac{a}{2}\right)+\sigma_{t} \cdot b(h-e)\left(\frac{h}{2}+\frac{e}{2}-\frac{a}{2}\right)
\end{gathered}
$$

Onde,

$c \quad=$ distância da fibra comprimida mais distante até a linha neura encontrada pelo equilíbrio de forças internas de tração e compressão;

$d=$ distância da fibra comprimida mais distante ao centroide da armadura de tração;

$e \quad=$ distância da fibra comprimida mais distante até o topo do bloco de tração do concreto fibroso;

$\varepsilon_{y} \quad=$ deformação de tração no aço $f_{y} / E_{s}$;

$\varepsilon_{s} \quad=$ deformação de tração na fibra de aço baseada na tensão desenvolvida no arrancamento (tensão dinâmica adesional);

$M_{n}=$ Momento nominal para um único reforço de fibras de aço;
$A_{s}$ = área da armadura de tração;
$f_{y}=$ tensão de escoamento das barras de aço;
$f_{c}^{\prime} \quad=$ resistência à compressão do concreto; 
$a \quad=$ profundidade do bloco retangular de compressão;

$\sigma_{t} \quad=$ resistência à tração do concreto fibroso;

$b, h$ = largura e altura da viga;

$V_{f} \quad=$ percentual em volume de fibras;

$F_{b e} \quad=$ eficiência de adesão da fibra que varia de 1,0 a 1,2.

O método para determinação da resistência residual à tração proposto no RILEM TC 162-TDF [97] se baseia na contabilização de forças equivalentes para considerar uma distribuição de tensões simplificada e constituir uma relação tensão-deformação para os concretos reforçados com fibras de aço (vide Figura $68)$.

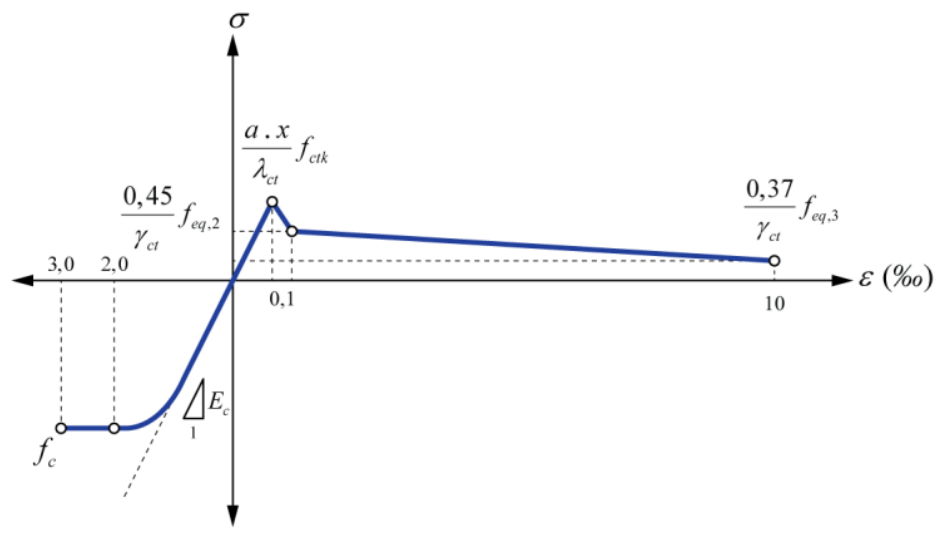

Figura 68 - Leis constitutivas do concreto reforçado com fibras de aço com base nas recomendações do RILEM TC 162-TDF [97]

a)

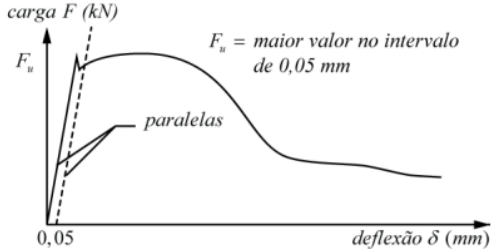

b)

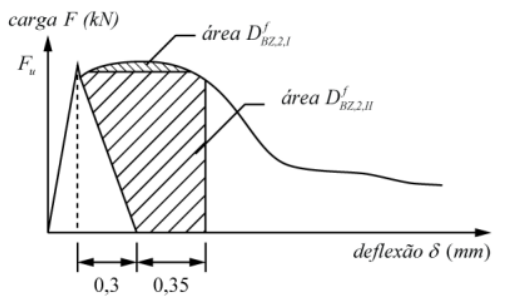

c)

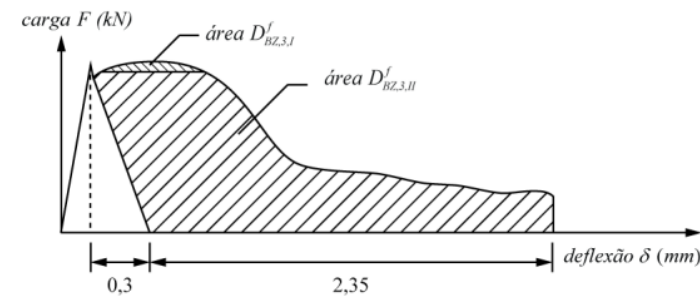

d)

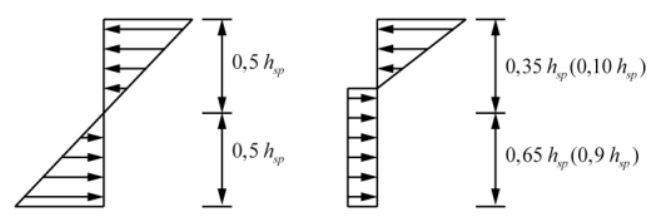

Figura 69 - llustração: a) do detalhe da reta paralela ao período inicial elástico do gráfico carga-deflexão utilizada para interceptar a curva e determinar a carga máxima $\left.F_{u} ; b-c\right)$ da contribuição das fibras na capacidade de absorção de energia; d) das distribuições de tensões simplificadas; adaptado do RILEM TC 162-TDF [97] 
O método do RILEM TC 162-TDF [97] considera duas distribuições de tensões distintas, uma linear correspondente à fase elástica, no limite de proporcionalidade (vide eq. (4.11)), e outra simplificada para a zona de pósfissuração (Figura 69d). Quando consideradas lineares ao longo de todo o ensaio, a tensão de tração na flexão pode ser calculada diretamente pela modificação da eq. (4.11) para considerar forças médias equivalentes contabilizadas para cada trecho hachurado do gráfico carga-deflexão (vide Figura 69b, Figura 69c e eqs. (4.12-4.15)). Para calcular estas áreas sobre os gráficos precisa-se definir a deflexão correspondente à carga do limite de proporcionalidade $\left(F_{u}\right)$, que é dada por uma reta paralela ao período elástico dos gráficos carga-deslocamento e que passa pela deflexão de 0,05 mm (vide Figura 69a). As resistências residuais à flexão necessárias para formar as relações constitutivas apresentadas na Figura 68 são calculadas pelas relações das eqs. (4.16-4.18).

$$
\begin{gathered}
f_{f c t, f l}=\frac{3 \cdot F_{u} \cdot L}{2 \cdot b \cdot h_{s p}^{2}} \\
F_{2}=\frac{D_{B Z, 2, \mathrm{I}}^{f}+\frac{D_{B Z, 2, I I}^{f}}{0,50}}{F_{3}=\frac{D_{B Z, 3, \mathrm{I}}^{f}}{2,65}+\frac{D_{B Z, 3, I I}^{f}}{2,50}} \\
f_{e q, 2}=\frac{3}{2}\left(\frac{D_{B Z, 2, \mathrm{I}}^{f}}{0,65}+\frac{D_{B Z, 2, I I}^{f}}{0,50}\right) \cdot \frac{L}{b \cdot h_{s p}^{2}} \\
f_{e q, 3}=\frac{3}{2}\left(\frac{D_{B Z, 3, \mathrm{I}}^{f}}{2,65}+\frac{D_{B Z, 3, I I}^{f}}{2,50}\right) \cdot \frac{L}{b \cdot h_{s p}^{2}} \\
\sigma_{f c t, 2}=\frac{0,45}{\lambda_{c t}} \cdot f_{e q, 2} \\
\sigma_{f c t, 3}=\frac{0,37}{\lambda_{c t}} \cdot f_{e q, 3} \\
\sigma_{f c}=\frac{0,85 \cdot f_{c k}}{\lambda_{c}}
\end{gathered}
$$


Onde,

$f_{f c t, f l} \quad=$ resistência à tração na fibra mais distante tracionada;

$F_{u} \quad=$ carga máxima correspondente à interseção da curva com uma reta paralela à zona elástica e que passa pela deflexão de 0,05 mm;

$b, L \quad$ = largura e distância do vão entre apoios do corpo de prova;

$h_{s p} \quad$ = distância da ponta do entalhe e o topo da seção transversal;

$D_{B Z, 2, \mathrm{I}}^{f}=$ contribuição das fibras na capacidade de absorção de energia para as áreas referidas na Figura 69;

$D_{B Z, 2, \text { II }}^{f} \quad=$ contribuição das fibras na capacidade de absorção de energia para as áreas referidas na Figura 69;

$D_{B Z, 3, \mathrm{I}}^{f}=$ contribuição das fibras na capacidade de absorção de energia para as áreas referidas na Figura 69;

$D_{B Z, 3, \mathrm{II}}^{f} \quad=$ contribuição das fibras na capacidade de absorção de energia para as áreas referidas na Figura 69;

$F_{2} F_{3} \quad=$ Forças médias correspondente às áreas da Figura 69b e Figura $69 c$;

$f_{\text {eq,2 }}=$ Tensão calculada com a força $F_{2}$ considerando uma distribuição de tensões linear (vide Figura 69d);

$f_{\text {eq }, 3}=$ Tensão calculada com a força $F_{3}$ considerando uma distribuição de tensões linear (vide Figura 69d);

$\sigma_{f c t, 2}=$ tensão residual de cálculo do concreto na tração $(0,1 \%)$;

$\sigma_{f c t, 3}=$ tensão residual de cálculo do concreto na tração $(10 \%)$;

$\sigma_{f c} \quad=$ tensão residual de tração $(10 \%)$;

$\lambda_{c t}, \lambda_{c}=$ fator de segurança parcial para determinação da resistência à tração e compressão, respectivamente;

$f_{c k} \quad=$ resistência característica do concreto à compressão. 
A fim de calcular as tensões residuais do concreto autoadensável reforçado por meio do método do RILEM TC 162-TDF [97], utilizou-se um único ensaio de CMOD (vide Figura 70). A partir da determinação da deflexão correspondente à carga do limite de proporcionalidade (vide Figura 70a) e da contabilização das regiões hachuradas dos gráficos da Figura 70b e Figura 70c, puderam-se calcular as forças equivalentes e as tensões residuais por meio das expressões $4.14,4.15,4.21$ e 4.22 .

a)

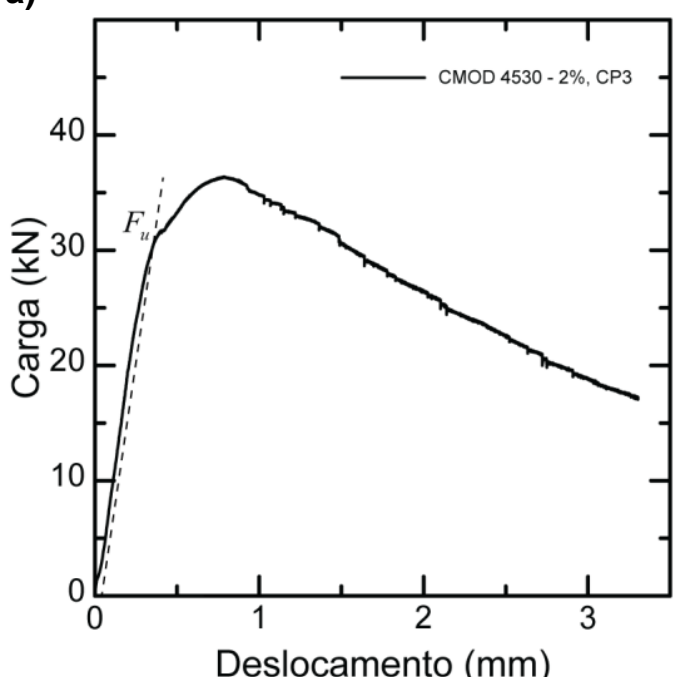

b)

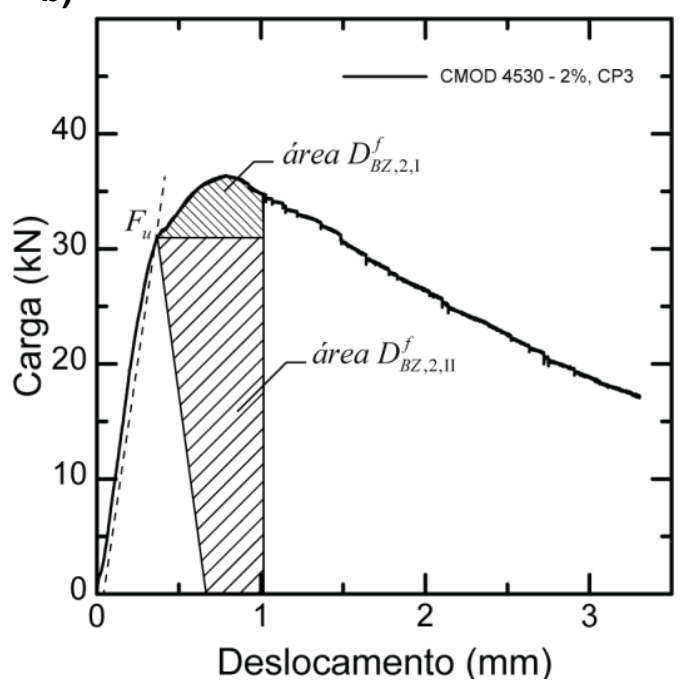

c)

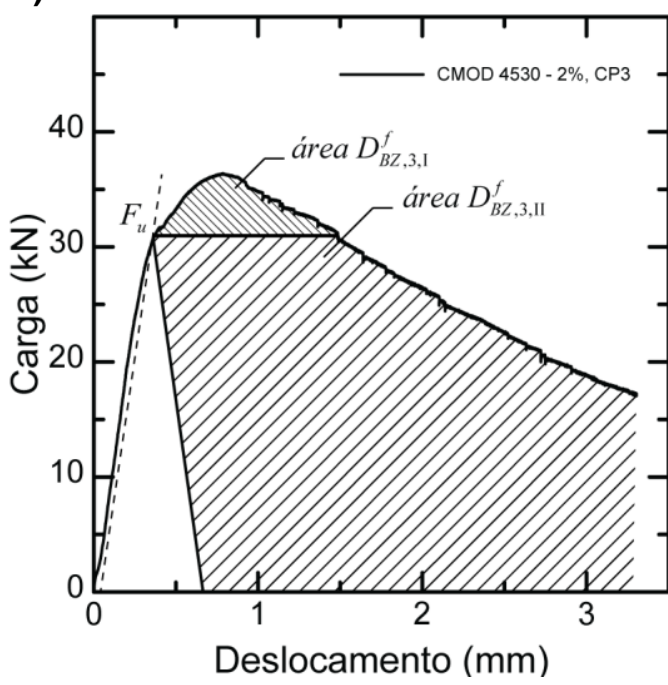

Figura 70 - Gráficos carga-deslocamento à flexão de um único corpo de prova prismático de $150 \times 150 \times 500 \mathrm{~mm}$ com entalhe de espessura $3 \mathrm{~mm}$ e profundidade $25 \mathrm{~mm}$, contendo: a) detalhe da reta paralela ao trecho elástico do gráfico cargadeslocamento; b-c) detalhes das áreas utilizadas para cálculo das forças residuais equivalentes 


$$
\begin{gathered}
f_{e q, 2}=\frac{3}{2}\left(\frac{2,51}{0,65}+\frac{12,27}{0,50}\right) \cdot \frac{500}{150 \cdot(150-25)^{2}}=9,09 \mathrm{MPa} \\
f_{e q, 3}=\frac{3}{2}\left(\frac{3,46}{2,65}+\frac{65,12}{2,50}\right) \cdot \frac{500}{150 \cdot(150-25)^{2}}=8,75 \mathrm{MPa} \\
\sigma_{f, 2}=0.45 \cdot f_{e q, 2}=4,09 \mathrm{MPa} \\
\sigma_{f, 3}=0,37 \cdot f_{e q, 3}=3,24 \mathrm{MPa}
\end{gathered}
$$

Utilizando o processo de cálculo da $\mathrm{ACl} 544.4 \mathrm{R}$ [40] e considerando as cargas residuais de tração calculadas pelos métodos da ACI 544.4R [40] e do RILEM TC 162-TDF [97], resultou-se nos momentos resistentes de cálculo exibidos na Tabela 18. Por meio da análise dos dados da mesma tabela, observa-se que a consideração da carga residual de tração incrementou os momentos resistentes em 21, 12 e $8 \%$, com relação às vigas armadas de referência, para as taxas geométricas de armaduras de 0,28, 0,45 e 0,70\%, respectivamente. Observa-se ainda pela análise da Tabela 18, que os momentos de cálculo resultantes dos modelos corresponderam às cargas obtidas nos ensaios experimentais para a abertura de fissuras de magnitude $0,2 \mathrm{~mm}$, atendendo também às condições de serviço, salvo os efeitos escala.

\section{Tabela 18 - Momentos resistentes característicos}

\section{Momentos resistentes característicos}

Resultados de capacidade de carga à primeira fissura, máxima e

de cálculo de vigas armadas e de vigas armadas e reforçadas com fibras de aço

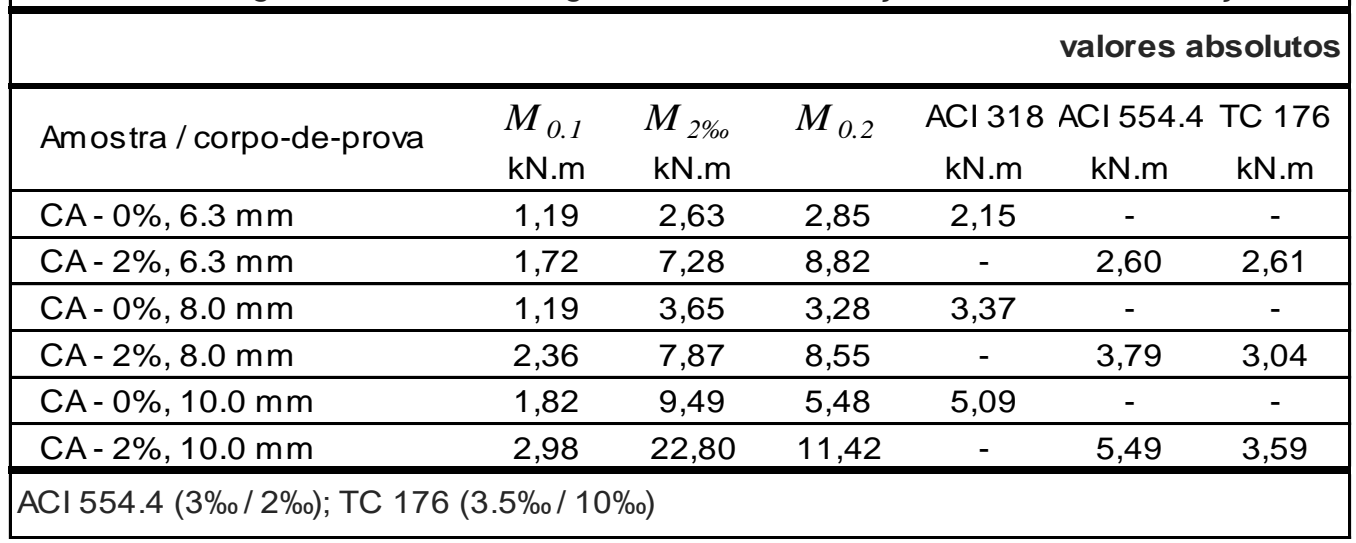




\section{5 \\ Conclusões}

O desempenho dos concretos reforçados com fibras de aço no estado fresco mostrou-se muito influenciado pela forma e comprimento das fibras, cujo melhor desempenho foi relacionado com os concretos reforçados com fibras com ganchos nas extremidades de comprimento $30 \mathrm{~mm}$ e razão de aspecto 45 , cujos valores de espalhamento se mantiveram superiores a $750 \mathrm{~mm}$ e os tempos de escoamento inferiores a 8 segundos em todas as frações volumétricas utilizadas $(0,5,1,0$ e $2,0 \%)$.

Observou-se nos ensaios de espalhamento, que os concretos reforçados com fibras torcidas de $25 \mathrm{~mm}$ e os concretos reforçados com fibras com ganchos de comprimento $60 \mathrm{~mm}$ obtiveram valores de espalhamento semelhantes para todas as frações volumétricas abordadas, porém com tempos de escoamento tão maiores quanto foram as razões de aspecto das fibras empregadas.

Os concretos reforçados com fibras torcidas de razão de aspecto 50 apresentaram desempenho no estado fresco inferior com relação àqueles que continham fibras com ganchos razão de aspecto semelhante, sugerindo que sua forma influenciou de forma negativa nos valores de espalhamento e tempos de escoamento.

Do ponto de vista da resistência à compressão axial, quando se utilizou um reforço com 2,0\% de fibras com ganchos de comprimento $30 \mathrm{~mm}$ e razão de aspecto 45 , obtiveram-se incrementos da ordem de $12 \%$ com relação à matriz de concreto autoadensável. Porém não se observaram alterações significativas no módulo elástico.

Sob tração, a adição do volume de 2,0 \% de fibras aleatoriamente dispersas na matriz atribuiu a capacidade de resistência residual média na zona de pós-fissuração dos concretos em 60 \%, com relação àquela observada na primeira fissura. Para esta mesma fração volumétrica, os concretos reforçados com fibras de aço de razão de aspecto 80 tiveram desempenho superior em 
termos da capacidade de absorção de energia, indicando que houve influência do seu maior comprimento médio de ancoragem, pois na seção transversal dos corpos de prova havia menor número destas fibras em comparação com as demais. Para as frações volumétricas de 0,5 e $1,0 \%$, as séries que contavam com reforço promovido pelas fibras torcidas razão de aspecto 45 tiveram valores de tenacidade acumulada média à deformação de $3 \%$ superiores àquelas observadas nas séries que continham fibras de razão de aspecto semelhante fato que se especula ser influência da geometria das fibras torcidas.

O ensaio de tração proposto neste trabalho resultou nos coeficientes de variação médios de ensaio menores que $10 \%$, mas se observou que as áreas de fibras presentes nas seções transversais dos corpos de prova não tiveram relação proporcional com o incremento da sua fração volumétrica, mostrando-se sensível à amostragem.

Da mesma maneira que na tração direta, a resistência à tração na flexão da matriz representou $8 \%$ da resistência correspondente à compressão. Quando se utilizou o reforço fibroso, observaram-se incrementos consideráveis nas deflexões, resultando no comportamento de deflection-hardening com aumento da ductilidade na zona de pós-fissuração e cargas residuais incrementadas em até $200 \%$. O reforço promovido pela adição de fibras torcidas de aspecto 50 na fração de $0,5 \%$ resultou em maiores cargas residuais e tenacidade quando comparadas às fibras com ganchos de aspecto semelhante. Entretanto, na fração volumétrica de 1,0 \% não se observou ganho efetivo com reforço destas fibras, sendo comparáveis àqueles obtidos à fração de 0,5\%.

Ao contrário do que se observou nos ensaios de flexão de prismas, os ensaios de flexão em painéis circulares exibiram grande dissipação de energia e deslocamentos correspondentes. De modo geral, as respostas dos gráficos carga-deslocamento à flexão dos painéis circulares se mostraram menos variáveis do que aqueles observados nos gráficos de flexão em prismas, mostrando sua melhor reprodutibilidade. Observou-se ainda, que a abertura média de fissuras medida na região central dos painéis circulares se deu a uma carga praticamente constante quando se utilizou frações volumétricas de 0,5 e $1,0 \%$, enquanto que na fração volumétrica de $2,0 \%$, houve recuperação de resistências. Este efeito se traduziu pelo aumento de rigidez à flexão promovido 
pelos mecanismos de arrancamento progressivo de fibras, cujo com comportamento de hardening foi observado.

Sobre o ponto de vista estrutural, observou-se que a adição de fibras dispersas na matriz de concreto autoadensável melhorou a manutenção da rigidez das vigas armadas sob flexão, resultando como consequência em menores deflexões. Por meio da análise das aberturas de fissuras características estimadas com auxilio de sistema de correlação digital de imagens, notou-se que as cargas correspondentes dos ensaios foram aumentas de maneira significativa quando houve emprego do reforço fibroso. Da mesma maneira, ao se comparar duas vigas com mesma taxa de armadura, uma com reforço e a outra sem, observou-se que fissuras de mesma magnitude ocorreram com atraso, correspondendo a maiores níveis de carga.

Do ponto de vista da capacidade de carga última obtida nos ensaios de flexão das vigas armadas, observou-se que a viga reforçada com taxa geométrica de armaduras $0,45 \%$ teve capacidade de carga máxima equivalente à obtida com a viga sem reforço e taxa geométrica de armaduras de 0,70\%, indicando que a inclusão de $2,0 \%$ de fibras com ganchos de comprimento $30 \mathrm{~mm}$ equivale-se à taxa geométrica de armaduras de 0,25\%. Salienta-se, porém, a necessidade de se avaliar a influência dos efeitos escala.

Conclui-se, que desempenho dos concretos reforçados com fibras torcidas de razão de aspecto 50 foi superior, em termos gerais, com relação àqueles observados por meio do reforço com fibras com ganchos de razão de aspeto 45 . Uma vez que as razões de aspecto destas fibras são semelhantes, sugere-se o melhor desempenho seja efeito da influência da geometria complexa das fibras torcidas. A única exceção se deu sob flexão e para os reforços com a fração volumétrica de $1,0 \%$, cujo desempenho dos concretos com ganchos foi sempre superior. Uma vez analisados os reforços promovidos pela adição de fibras na fração volumétrica de 2,0 \%, observa-se que há maior influência do comprimento ancorado, pois com menor número de fibras passando nas seções transversais dos corpos de prova, os concretos reforçados fibras com ganchos de comprimento $60 \mathrm{~mm}$ mostram-se superiores em termos das cargas residuais e energias absorvidas. 
6

\section{Referências bibliográficas}

1. AMERICAN SOCIETY FOR TESTING AND MATERIALS. ASTM C1550-12: Standard Test Method for Flexural Toughness of Fiber Reinforced Concrete (Using Centrally Loaded Round Panel). United States: ASTM International, 2012.

2. ASSOCIAÇÃO BRASILEIRA DE NORMAS TÉCNICAS. NBR 15146-12011: Controle tecnológico de concreto - Qualificação de pessoal - Parte 1: Requisitos gerais. Rio de Janeiro: ABNT, 2011.

3. AMERICAN SOCIETY FOR TESTING AND MATERIALS. ASTM C1611-05: Standard Test Method for Slump Flow of Self-Consolidating Concrete. United States: ASTM International, 2005.

4. AMERICAN SOCIETY FOR TESTING AND MATERIALS. ASTM C39-03: Standard Test Method for Compressive Strength of Cylindrical Concrete Specimens. United States: ASTM International, 2003.

5. AMERICAN SOCIETY FOR TESTING AND MATERIALS. ASTM C469-14: Standard Test Method for Static Modulus of Elasticity and Poisson's Ratio of Concrete in Compression. United States: ASTM International, 2014.

6. AMERICAN SOCIETY FOR TESTING AND MATERIALS. ASTM C1609-12: Standard Test Method for Flexural Performance of Fiber-Reinforced Concrete. United States: ASTM International, 2012.

7. NEVILLE, A. M. Properties of concrete. 4ª . ed. Harlow: Pearson Education Limited, 2002. 844 p.

8. AIITCIN, P. C. Cements of Yesterday and Today. Cement and Concrete Research, v. 30, p. 1349-1359, Julho 2000.

9. AïTCIN, P. C. High-Performance Concrete. $2^{\text {a }}$. ed. New York: Taylor \& Francis, 2004. 569 p.

10. AMERICAN CONCRETE INSTITUTE. ACI 116R-00: Cement and Concrete Terminology. United States: American Concrete Institute, 2000.

11. AMERICAN SOCIETY FOR TESTING AND MATERIALS. ACI C125-15: 
Standard Terminology Relating to Concrete and Concrete Aggregates. United States: ASTM International, 2015.

12. AMERICAN CONCRETE INSTITUTE. ACI CT-2016: ACl Concrete Terminology. United States: American Concrete Institute, 2016.

13. NAAMAN, A. E. Tensile strain-hardening FRC composites: Historical evolution since the 1960. In: GROSSE, C. U. Advances in Construction Materials. 1a. ed. New York: Springer, 2007. p. 181-202.

14. ZOLLO, R. F. Fiber-reinforced Concrete: an Overview after 30 Years of Development. Cement and Concrete Composites, v. 19, p. 107-122, Outubro 1996.

15. AMERICAN CONCRETE INSTITUTE. ACI 544.1R-96: State-of-the-Art Report on Fiber Reinforced Concrete. United States: American Concrete Institute, 1996.

16. BENTUR, A.; MINDESS, S. Fibre Reinforced Cementitious Composites. 2 ${ }^{\mathrm{a}}$. ed. London: Taylor \& Francis, 2007. 601 p.

17. MEHTA, P. K.; MONTEIRO, P. J. M. Concrete: Microstructure, Properties, and Materials. 33. ed. New York: McGraw-Hill, 2006.

18. AMERICAN SOCIETY FOR TESTING AND MATERIALS. ASTM A820-06: Standard Specification for Steel Fibers for Fiber-Reinforced Concrete. United States: ASTM International, 2006.

19. AMERICAN CONCRETE INSTITUTE. ACI 544.3R-93: Guide of Specifying, Proportioning, Mixing, Placing, and Finishing Steel Fiber Reinforced Concrete. United States: American Concrete Institute, 1993.

20. BRITISH STANDARD. BS EN 14889-06: Fibres for concrete - Part 1: Steel fibres - Definitions, specifications and conformity. United Kingdom: European Committee for Standardization, 2006.

21. BRITISH STANDARD. BS EN 206-13: Concrete: Especification, performance, production and conformity. United Kingdom: European Committee for Standardization, 2013.

22. AÏTCIN, P. C. Developments in the aplication of high-performance concretes. Construction and Building Materials, v. 9, p. 13-17, Maio 1995.

23. DE LARRARD, F.; SEDRAN, T. Mixture-proportioning of high-performance concrete. Cement and Concrete Research, p. 1699-1704, Janeiro 2002. 
24. BROUWERS, H. J. H.; RADIX, H. J. Self-Compacting Concrete: Theoretical and experimental study. Cement and Concrete Research, p. 2116-2136, Junho 2005.

25. FERRARA, L.; PARK, Y.-D.; P. SHAH, S. A method for mix-design of fiberreinforced self-compacting concrete. Cement and Concrete Research, $p$. 957-971, Março 2007.

26. MARANGON, E. Desenvolvimento e Caracterização de Concretos Autoadensáveis Reforçados com Fibras de Aço. Rio de Janeiro: Dissertação de Mestrado - Universidade Federal do Rio de Janeiro (COPPE/UFRJ), 2006. $142 \mathrm{p}$.

27. SUURONEN, J.-P. et al. Analysis of short fibres orientation in steel fibrereinforced concrete (SFRC) by X-ray tomography. Springer Science, $p$. 1358-1367, Outubro 2012.

28. STÄHLI, P.; G.M. VAN MIER, J. Manufacturing, fibre anisotropy and fracture of hybrid fibre concrete. Engineering Fracture Mechanics, p. 223-242, Março 2006.

29. ŠVEC, O. et al. Influence of formwork surface on the orientation of steel fibres within self-compacting concrete and on the mechanical properties of cast structural elements. Cement \& Concrete Composites, p. 60-72, Setembro 2013.

30. J. BARNETT, S. et al. Assessment of fibre orientation in ultra high performance fibre reinforced concrete and its effect on flexural strength. Materials and Structures, p. 1009-1023, Outubro 2009.

31. LARANJEIRA, F. et al. Characterization of the orientation profile of steel fiber reinforced concrete. Materials and Structures, p. 1093-1111, Outubro 2010.

32. RAMBO, D. A. S. Concretos autoadensáveis reforçados com fibras de aço híbridas: aspectos materiais e estruturais. Rio de Janeiro: Dissertação de Mestrado - Universidade Federal do Rio de Janeiro (COPPE/UFRJ), 2012. $185 \mathrm{p}$.

33. FERRARIS, C. F. Measurement of the Rheological Properties of High Performance Concrete: State of the Art Report. Journal of Research of the National Institute of Standards and Technology, p. 461-478, Outubro 1999.

34. DE LARRARD, F.; HU, C. The Rheology of Fresh High-performance 
Concrete. Cement and Concrete Research, p. 283-294, Outubro 1995.

35. FERRARIS, C. F.; , F. D. L. Testing and Modelling of Fresh Concrete Rheology. NIST: National Institute of Standards and Technology. Gaithersburg, p. 71. 1998.

36. P., W. Understanding the rheology of concrete. 1' ${ }^{\text {a }}$ ed. Philadelphia: Woodhead Publishing in Materials, 2012.

37. DE LARRARD, F. Concrete Mixture Proportioning: A Scientific Approach. London: E \& FN SPON, 2011. 419 p.

38. S. P. S. et al. Self-consolidating concrete: Now and Future. International Symposium on Design, Performance and Use of Self-Consolidating Concrete, p. 3-15, Junho 2009.

39. M. F. ASMUS, S.; J. CHRISTENSEN, B. Status of Self Consolidating Concrete (SCC) in Asia Pacific. International Symposium on Design, Performance and Use of Self-Consolidating Concrete, p. 35-42, Junho 2009.

40. AMERICAN CONCRETE INSTITUTE. ACI 544.4R-88: Design Considerations for Steel Fiber Reinforced Concrete. United States: American Concrete Institute, 1988.

41. NAAMAN, A. E. Evaluation of steel fibers for applications in structural concrete. 6th International RILEM Symposium on Fibre Reinforced Concretes, p. 389-400, Agosto 2004.

42. A. M. B. Cement-Based Composites: Materials, mechanical properties and performance. $2^{\mathrm{a}}$. ed. New York: Taylor \& Francis, 2009. 518 p.

43. OLIVEIRA, F. L. D. Design-oriented constitutive model for steel fiber reinforced concrete. Catalunya: Tese de Doutorado - Universitat Politècnica de Catalunya, 2010.

44. KAW, A. K. Mechanics of Composite Materials. 1‥ ed. New York: Taylor \& Francis, 2006. $457 \mathrm{p}$.

45. AVESTON, J.; , A. K. Theory of multiple fracture of fibrous composites. Journal of Materials Science, p. 352-362, Setembro 1972.

46. C. LI, V. et al. Tensile Behavior of Cement-Based Composites with Random Discontinuous Steel Fibers. Journal of the American Ceramic Society, p. 74-78, Outubro 1994.

47. MASO, J. C. Interfacial Transition Zone in Concrete - State-of-Art 
Report prepared by RILEM Technical Commitee 108-ICC, Interfaces in Cementitious Composites. 1‥ ed. London: E \& FN Spon, 1996. 197 p.

48. COX, H. L. The elasticity and stregth of paper and other fibrous materials. The National Physical Laboratory, Teddington, p. 72-79, Agosto 1951.

49. BARTOS, P. Review paper: Bond in fibre reinforced cements and concretes. The international Journal of Cement Composites, Paisley, p. 159-177, Agosto 1981.

50. NAAMAN, A. E. et al. Fiber Pullout and Bond Slip. I: Analytical Study. Journal of Structural Engineering, p. 2769-2790, Setembro 1991.

51. C. LI, V.; STANG, H. Interface Property Characterization and Strengthening Mechanisms in Fiber Reinforced Cement Based Composites. Advanced Cement Based Materials, Lyngby, p. 1-20, Fevereiro 1997.

52. BENTUR, A. et al. Fiber-matrix interfaces. In: MATÉRIAUX, R. R. I. D. L. E. E. D. High Performance Fiber Reinforced Cement Composites 2 (HPFRCC2). London: E \& FN Spon, 1996. p. 150-185.

53. ALWAN, J. M.; NAAMAN, A. E.; HANSEN, W. Pull-Out Work of Steel Fibers From Cementitious Composites: Analytical Investigation. Cement \& Concrete Composites, p. 247-255, Maio 1991.

54. ISLA, F.; RUANO, G.; LUCCIONI, B. Analysis of steel fibers pull-out. Experimental study. Construction and Building Materials, p. 183-193, Setembro 2015.

55. VAN MIER, J. G. M. Concrete Fracture: A Multiscale Approach. 1‥ ed. London: Taylor \& Fancis Group, 2013. 315 p.

56. MOBASHER, B. Mechanics of Fiber and Textile Reinforced Cement Composites. 1‥ ed. London: Taylor \& Fancis Group, 2012. 438 p.

57. LI, V. C.; STANG, H.; KRENCHEL, H. Micromechanics of crack bridging in fibre-reinforced concrete. Materials and Structures, p. 486-494, Outubro 1993.

58. SCHLANGEN, E.; VAN MIER, J. G. M. Experimental and Numerical Analysis of Micromechanisms of Fracture of Cement-Based Composites. Cement and concrete Composites, p. 105-118, 1992.

59. KARIHALOO, B. L.; CARPINTERI, A.; ELICES, M. Fracture Mechanics of Cement Mortar and Plain Concrete. Advanced Cement Based Materials, p. 92-105, Dezembro 1993. 
60. BETTERMAN, L. R.; OUYANG, C.; SHAH, S. P. Fiber-Matrix Interaction in Microfiber-Reinforced Mortar. Advanced Cement Based Materials, p. 5361, Março 1995.

61. LI, V. C.; , M. M. Thoughening in Cement Based Composites. Part I: Cement, Mortar, and Concrete. Cement and Concrete Composites, p. 223-237, Fevereiro 1996.

62. LI, V. C.; , M. M. Thoughening in Cement Based Composites. Part II: Fiber Reinforced Cementitious Composites. Cement and Concrete Composites, p. 239-249, Fevereiro 1996.

63. OHTSU, M. Acoustic Emission (AE) and Related Non-destructive Evaluation (NDE) Techiniques in the Fracture Mechanics of Concrete. London: Woodhead Publishing, 2015. 291 p.

64. SHI, Z. Analysis in Structural Concrete. Burlington: ButterworthHeinemann, 2009. 327 p.

65. LÖFGREN, I. Fibre-reinforced Concrete for Industrial Construction. Göteborg: Tese de Doutorado - Chalmers University of Technology, 2005. $277 \mathrm{p}$.

66. FÉDÉRATION INTERNATIONALE DU BÉTON. CEB-FIP: Model Code 2010. 1a. ed. Lausanne: International Federation for Structural Concrete (FIB), v. 2, 2012. $331 \mathrm{p}$.

67. NAAMAN, A. E.; HOMRICH, J. R. Stress-strain properties of SIFCON in unixial compression and tension. Michigan University, Ann Arbor, 1988.

68. WILLE, K.; JOO KIM, D.; NAAMAN, A. E. Strain-hardening UHP-FRC with low fiber contents. Materials and Structures, p. 583-598, Julho 2011.

69. DE LARRARD, F.; SEDRAN, T. Optimization of Ultra-high-performance Concrete by the Use of a Packing Model. Cement and Concrete Research, p. 997-1009, Setembro 1994.

70. BANCHE, H. H. Densified cement/ultrafine particle-based materials. 2nd International conference on superplasticizers in concrete, Aalborg, 1981.

71. RÉUNION INTERNATIONALE DES LABORATOIRES ET EXPERTS DES MATÉRIAUX. RILEM State of the Art Reports: Mechanical Properties of Self-Compacting Concrete. London: Springer, 2014. 286 p.

72. R.A. VAN VLIET, M.; G.M. VAN MIER, J. Experimental investigation of size 
effect in concrete and sandstone under uniaxial tension. Engineering Fracture Mechanics, p. 165-188, Outubro 1998.

73. G.M. VAN MIER, J.; R.A. VAN VLIET, M. Influence of microstructure of concrete on size/scale effects in tensile fracture. Engineering Fracure Mechanics, p. 2281-2306, Setembro 2002.

74. AMERICAN CONCRETE INSTITUTE. ACI 554.2R-89: Measurement of Properties of Fiber Reinforced Concrete. United States: American Concrete Institute, 1989.

75. AMERICAN SOCIETY FOR TESTING AND MATERIALS. ASTM C496-11: Standard Test Method for Splitting Tensile Strength of Cylindrical Concrete Specimens. United States: ASTM International, 2011.

76. XU, B. W.; SHI, H. S. Correlations among mechanical properties of steel fiber reinforced concrete. Construction and Building Materials, p. 34683474, Agosto 2009.

77. BEHNOOD, A.; PIN VERIAN, K.; MODIRI GHAREHVERAN, M. Evaluation of the splitting tensile strength in plain and steel fiber-reinforced concrete based on the compressive strength. Construction and Building Materials, p. 519-529, Agosto 2015.

78. WILLE, K.; EL TAWIL, S.; NAAMAN, A. E. Properties of strain hardening ultra high performance fiber reinforced concrete (UHP-FRC) under direct tensile loading. Cement \& Concrete Composites, Dezembro 2013. 53-66.

79. DI PRISCO, M.; LAMPERTI, M. G. L.; LAPOLLA, S. Double-edge wedge splitting test: preliminary results. Fracture Mechanics of Concrete and Concrete Structures - High Performance, Fiber Reinforced Concrete, Special Loadings and Structural Applications, p. 1579-1586, 2010.

80. DI PRISCO, M.; FERRARA, L.; LAMPERTI, M. G. L. Double edge wedge splitting (DEWS): an indirect tension test to identify post-cracking behaviour of fibre reinforced cementitious composites. Materials and Structures, $p$. 1893-1918, Fevereiro 2012.

81. CHEN, W. F. Double Punch Test for Tensile Strength of Concrete. Department of Civil Engineering, Pennsylvania, p. 18, Julho 1973.

82. MOLINS, C.; AGUADO, A.; SALUDES, S. Double Punch Test to control the energy dissipation in tension of SRC (Barcelona test). Materials and Structures, p. 415-425, Maio 2008.

83. NAAMAN, A. E.; FISCHER, G.; KRSTULOVIC-OPARA, N. Measurement of 
Tensile Properties of Fiber Reinforced Concrete: Draft Submited to $\mathrm{ACl}$ Committee 544, 2014. 10.

84. TJIPTOBROTO, P.; HANSEN, W. Mechanism for Tensile Strain Hardening in High Performance Cement-based Fiber Reinforced Composites. Cement \& Concrete Composites, p. 265-273, Outubro 1991.

85. SUWANNAKARN, S.; EL-TAWIL, S.; NAAMAN, A. E. Experimental Observations on the Tensile Response of Fiber Reinforced Cement Composites With Different Fibers. Fifth International RILEM Workshop on High Performance Fiber Reinforced Cement Composites, 2014.

86. Y. ZENG, J.; MURAKAMI, H. Experimental and analytical study of SIMCON tension members. Mechanics of Materials, p. 181-195, Março 1997.

87. KANG, S.-T. et al. Hybrid effects of steel fiber and microfiber on the tensile behavior of ultra-high performance concrete. Composite Structures, p. 3742, Março 2016.

88. RAMBO, D. A. S.; ANDRADE SILVA, F.; DIAS TOLEDO FILHO, R. Flexural behavior of hybrid steel fiber reinforced self-consolidating concretes. Materials and Design, p. 32-42, Agosto 2013.

89. WILLE, $\mathrm{K}$. et al. Ultra-high performance concrete and fiber reinforced concrete: archieving strength and ductility without heat curing, Julho 2011. 309-324.

90. LIAO, W.-C. et al. Self-consolidating high performance fiber reinforced concrete: SCHPFRC. Fifth International RILEM Workshop on High Performance Fiber Reinforced Cement Composites, 2014. 293-302.

91. AMERICAN CONCRETE INSTITUTE. ACI 554.8R-16: Report on Indirect Method to Obtain Stress-Strain Response of Fiber-Reinforced Concrete (FRC). United States: American Concrete Institute, 2016.

92. NAAMAN, A. E.; REINHARDT, H. W. Proposed classification of HPFRC composites based on their tensile response, p. 547-555, Dezembro 2005.

93. AMERICAN SOCIETY FOR TESTING AND MATERIALS. ASTM C1018-97: Standard Test Method for Flexural Toughness and First-Crack Strength of Fiber-Reinforced Concrete (Using Beam With Third-Point Loading). United States: ASTM International, 1997.

94. KIM, D. J.; NAAMAN, A. E.; EL-TAWIL, S. Comparative flexural behavior of four fiber reinforced cementitious composites. Cement \& Concrete Composites, p. 917-928, Agosto 2008. 
95. WEI, S.; JIANZHONG, L.; JIAO, C. Study of the mechanical behavior of ECO-RPC under static and dynamic loads. 6th RILEM Symposium of Fibre-Reinforced Concretes (FRC), 2004. 1411-1420.

96. PAJąK, M. Investigation on Flexural Properties of Hybrid Fibre Reinforced Self-Compacting Concrete. World Multidisciplinary Civil EngineeringArchitecture-Urban Planning Symposium, p. 121-126, 2016.

97. RÉUNION INTERNATIONALE DES LABORATOIRES ET EXPERTS DES MATÉRIAUX. RILEM TC 162-TDF: Test and design methods for steel fibre reinforced concrete. Materials and Structures, Outubro 2003. 560-567.

98. EUROPEAN STANDARD. BS EN 14651-2005: Test method for metallic concrete - Measuring the flexural tensile strength (limit of proportionality (LOP), residual). United Kingdom: European Committee for Standardization, 2005.

99. MOBASHER, B.; YAO, Y.; SORANAKOM, C. Analytical solutions for flexural design of hybrid steel fiber reinforced concrete beams. Engineering Structures, p. 164-177, Junho 2015.

100. MINELLI, F.; PLIZZARI, G. A New Round Panel Test for the Characterization of Fiber Reinforced Concrete: A Broad Experimental Study. Journal of Testing and Evaluation, p. 889-897, Junho 2010.

101. EUROPEAN FEDERATION OF NATIONAL ASSOCIATIONS REPRESENTING FOR CONCRETE. EFNARC: European Specification for Sprayed Concrete, 1996.

102. BENTUR, A.; MINDESS, S. Concrete beams reinforced with conventional steel bars and steel fibres: properties in static loading. The international Journal of Cement Composites and Lightweight Concrete, p. 199-202, Agosto 1983.

103. BISCHOFF, P.; BERUBE, F.; LAWRENCE, G. Use of Steel Fibres to Enhance Bond and Development of Reinforcing Bars in High-strength Reinforced Concrete Beams. 6th RILEM Symposium on Fibre-Reinforced Concretes (FRC), p. 1103-1112, Agosto 2004.

104. ALTUN, F.; HAKTANIR, T.; ARI, K. Effects of steel fiber addition on mechanical properties of concrete and RC beams. Construction and Building Materials, p. 654-661, Dezembro 2005.

105. HOLSCHEMACHER, K.; MUELLER, T.; RIBAKOV, Y. Effect of steel fibres on mechanical properties of high-strength concrete. Materials and Design, 
p. 2604-2615, Novembro 2009.

106. A. BARAKAT, S.; ALTOUBAT, S. Concrete welding using steel fibers. Engineering Structures, p. 2065-2073, Março 2010.

107. NING, X. et al. Experimental study and prediction model for flexural behavior of reinforced SCC beam containing steel fibers. Construction and Building Materials, p. 644-653, Junho 2015.

108. ASSOCIAÇÃO BRASILEIRA DE NORMAS TÉCNICAS. NBR 5733-1991: Cimento Portland de alta resistência inicial. Rio de Janeiro: ABNT, 1991.

109. ASSOCIAÇÃO BRASILEIRA DE NORMAS TÉCNICAS. NBR NM 248: Agregados - Determinação da composição granulométrica. Rio de Janeiro: ABNT, 2003.

110. ASSOCIAÇÃO BRASILEIRA DE NORMAS TÉCNICAS. NBR 11768-2011: Aditivos químicos para concreto de cimento Portland - Requisitos. Rio de Janeiro: ABNT, 2011.

111. AMERICAN CONCRETE INSTITUTE. ACI 237R-07: Self-Consolidating Concrete. United States: American Concrete Institute, 2007.

112. ASSOCIAÇÃO BRASILEIRA DE NORMAS TÉCNICAS. NBR 15823-1: Concreto auto-adensável - Parte 1: Classificação, controle e aceitação no estado fresco. Rio de Janeiro: ABNT, 2010.

113. GRIMALDI, A.; OLIVITO, R. S.; RINALDI, Z. Behaviour of R.C. Beams Reinforced With FRC Material: Analytical - Experimental Evaluation. 6th International RILEM Symposium on Fibre-Reinforced Concretes (BEFIB'2004), Setembro 2004. 1035-1044.

114. ASSOCIAÇÃO BRASILEIRA DE NORMAS TÉCNICAS. NBR 6118-14: Projeto de estruturas de concreto - Procedimento. Rio de Janeiro: ABNT, 2014. 
7

ANEXOS

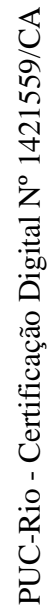


7.1

ANEXO I - Resultados individuais dos ensaios

Tabela 19 - Resumo das resistências individuais dos ensaios de tração direta

\begin{tabular}{|c|c|c|c|c|c|c|c|c|}
\hline \multicolumn{9}{|c|}{$\begin{array}{l}\text { Valores característicos individuais } \\
\text { Resultados de resistência de pico e pós-pico, individuais } \\
\text { de tração direta em corpos de prova dog bone shaped }\end{array}$} \\
\hline \multirow[b]{2}{*}{$\begin{array}{l}\text { Exemplar / corpo de } \\
\text { prova }\end{array}$} & \multirow[b]{2}{*}{$\begin{array}{c}\varepsilon_{p} \\
\%\end{array}$} & \multirow[b]{2}{*}{$\begin{array}{l}P_{p} \\
\mathrm{kN}\end{array}$} & \multirow[b]{2}{*}{$\begin{array}{c}f_{p} \\
\mathrm{MPa}\end{array}$} & \multirow[b]{2}{*}{$\begin{array}{c}P_{0,5} \\
\mathrm{kN}\end{array}$} & \multirow[b]{2}{*}{$\begin{array}{l}f_{0,5} \\
\mathrm{MPa}\end{array}$} & \multicolumn{3}{|c|}{ valores absolutos } \\
\hline & & & & & & $\begin{array}{c}E \\
\mathrm{GPa}\end{array}$ & $\begin{array}{c}T_{3} \\
\mathrm{Jm}^{-3} 10^{4}\end{array}$ & $\begin{array}{c}f_{0,5} / f_{p} \\
\%\end{array}$ \\
\hline CAA - 0\%, CP1 & 0,013 & 25,25 & 6,95 & - & - & 39 & - & \\
\hline CAA - 0\%, CP2 & 0,013 & 23,05 & 6,35 & - & - & 49 & - & \\
\hline CAA - 0\%, CP3 & 0,011 & 17,53 & 4,83 & - & - & 47 & - & \\
\hline HE $45 / 30-0.5 \%$, CP1 & 0,015 & 21,12 & 5,82 & 07,20 & 1,98 & 41 & 4,02 & 34 \\
\hline HE $45 / 30-0.5 \%$, CP2 & 0,017 & 17,90 & 4,93 & 03,28 & 0,90 & 31 & 1,16 & 18 \\
\hline HE $45 / 30-0.5 \%$, CP3 & 0,016 & 15,03 & 4,14 & 03,39 & 0,93 & 36 & 1,76 & 23 \\
\hline HE $45 / 30-1 \%$, CP1 & 0,014 & 17,45 & 4,80 & 05,85 & 1,61 & 34 & 2,41 & 34 \\
\hline HE 45/30 - 1\%, CP2 & 0,016 & 19,27 & 5,31 & 07,47 & 2,06 & 35 & 3,65 & 39 \\
\hline HE $45 / 30-1 \%$, CP3 & 0,018 & 19,02 & 5,24 & 07,62 & 2,10 & 27 & 3,35 & 40 \\
\hline HE $45 / 30-2 \%$, , 1 & 0,013 & 16,26 & 4,48 & 09,31 & 2,56 & 28 & 4,44 & 57 \\
\hline HE 45/30 - 2\%, CP2 & 0,014 & 17,99 & 4,95 & 06,96 & 1,92 & 36 & 3,30 & 39 \\
\hline HE 45/30 - 2\%, CP3 & 0,011 & 15,24 & 4,20 & 11,26 & 3,10 & 38 & 5,39 & 74 \\
\hline HE 80/60 - 0.5\%, CP1 & 0,012 & 16,61 & 4,57 & 05,62 & 1,55 & 39 & 3,29 & 34 \\
\hline HE 80/60 - 0.5\%, CP2 & 0,021 & 15,75 & 4,34 & 02,96 & 0,82 & 23 & 1,86 & 19 \\
\hline HE 80/60 - 0.5\%, CP3 & 0,015 & 19,72 & 5,12 & 06,54 & 1,70 & 26 & 2,69 & 33 \\
\hline HE 80/60 - 1\%, CP1 & 0,014 & 21,24 & 5,85 & 02,22 & 0,61 & 30 & 1,66 & 10 \\
\hline HE 80/60 - 1\%, CP2 & 0,016 & 21,20 & 5,84 & 07,98 & 2,20 & 35 & 4,69 & 38 \\
\hline HE $80 / 60-1 \%$, CP3 & 0,015 & 21,28 & 5,86 & 08,28 & 2,28 & 37 & 2,59 & 39 \\
\hline HE $80 / 60-2 \%$, CP1 & 0,012 & 17,05 & 4,70 & 11,80 & 3,25 & 33 & 8,47 & 69 \\
\hline HE $80 / 60$ - 2\%, CP2 & 0,017 & 21,50 & 5,92 & 14,46 & 3,98 & 34 & 7,31 & 67 \\
\hline HE 80/60 - 2\%, CP3 & 0,013 & 17,69 & 4,87 & 11,46 & 3,16 & 31 & 6,58 & 65 \\
\hline TW 50/25 - 0.5\%, CP1 & 0,019 & 21,75 & 5,99 & 04,42 & 1,22 & 35 & 2,46 & 20 \\
\hline TW 50/25 - 0.5\%, CP2 & 0,017 & 21,70 & 5,97 & 06,78 & 1,87 & 36 & 3,20 & 31 \\
\hline TW 50/25 - 0.5\%, CP3 & 0,017 & 17,43 & 4,80 & 04,39 & 1,21 & 31 & 1,92 & 25 \\
\hline TW 50/25 - 1\%, CP1 & 0,013 & 19,60 & 5,40 & 08,95 & 2,46 & 38 & 4,14 & 46 \\
\hline TW 50/25 - 1\%, CP2 & 0,016 & 17,72 & 4,88 & 06,83 & 1,88 & 32 & 2,87 & 39 \\
\hline TW 50/25 - 1\%, CP3 & 0,015 & 17,65 & 4,86 & 06,40 & 1,76 & 29 & 2,79 & 36 \\
\hline TW 50/25 - 2\%, CP1 & 0,018 & 18,33 & 5,05 & 11,24 & 3,10 & 29 & 6,09 & 61 \\
\hline TW 50/25 - 2\%, CP2 & 0,016 & 15,84 & 4,36 & 10,77 & 2,97 & 25 & 5,23 & 68 \\
\hline TW 50/25 - 2\%, CP3 & 0,013 & 15,24 & 4,20 & 09,71 & 2,67 & 27 & 4,75 & 64 \\
\hline
\end{tabular}


Tabela 20 - Resumo dos resistências individuais dos ensaios de flexão em corpos de prova prismáticos

Valores característicos individuais à flexão

Resultados de resistência, deformações de pico e pós-pico de corpos de prova prismáticos sob flexão

valores absolutos

\begin{tabular}{|c|c|c|c|c|c|c|c|c|c|c|}
\hline Exemplar / corpo de & $\delta_{p}$ & $P_{p}$ & $f_{p}$ & $P_{1}$ & $f_{1}$ & $P_{2}$ & $f_{2}$ & $T_{5}$ & \multicolumn{2}{|c|}{$f_{1} / f_{p} f_{2} / f_{p}$} \\
\hline$p$ & $\mathrm{~mm}$ & $\mathrm{kN}$ & $\mathrm{MPa}$ & $\mathrm{kN}$ & $\mathrm{MPa}$ & $\mathrm{kN}$ & $\mathrm{MPa}$ & $\mathrm{J}$ & $\%$ & $\%$ \\
\hline CAA - 0\%, CP1 & 0,14 & 29,8 & 6,19 & - & - & - & - & - & - & - \\
\hline CAA - 0\%, CP2 & 0,13 & 29,6 & 6,14 & - & - & - & - & - & - & - \\
\hline CAA - 0\%, CP3 & 0,14 & 28,8 & 5,98 & - & - & - & - & - & - & - \\
\hline HE 45/30 - 0.5\%, CP1 & 0,14 & 29,6 & 6,15 & 20,5 & 04,29 & 09,1 & 01,95 & 053 & 069 & 031 \\
\hline HE 45/30 - 0.5\%, CP2 & 0,14 & 29,8 & 6,19 & 15,2 & 03,20 & 07,9 & 01,71 & 043 & 051 & 027 \\
\hline HE 45/30 - 0.5\%, CP3 & 0,14 & 30,7 & 6,37 & 14,2 & 03,00 & 06,2 & 01,36 & 041 & 046 & 020 \\
\hline HE 45/30 - 1\%, CP1 & 0,13 & 28,3 & 5,88 & 34,5 & 07,16 & 20,2 & 04,23 & 094 & 122 & 072 \\
\hline HE 45/30 - 1\%, CP2 & 0,15 & 30,4 & 6,32 & 38,4 & 07,94 & 27,6 & 05,74 & 117 & 126 & 091 \\
\hline HE 45/30 - 1\%, CP3 & 0,15 & 30,2 & 6,28 & 30,0 & 06,23 & 15,1 & 03,19 & 077 & 099 & 050 \\
\hline HE 45/30 - 2\%, CP1 & 0,17 & 33,8 & 7,00 & 57,3 & 11,82 & 43,8 & 09,06 & 174 & 170 & 130 \\
\hline HE 45/30 - 2\%, CP2 & 0,13 & 28,1 & 5,85 & 48,5 & 10,01 & 41,8 & 08,65 & 183 & 172 & 149 \\
\hline HE 45/30 - 2\%, CP3 & 0,13 & 27,3 & 5,67 & 42,4 & 08,76 & 37,4 & 07,74 & 165 & 155 & 137 \\
\hline HE 80/60 - 0.5\%, CP1 & 0,15 & 30,9 & 6,41 & 16,9 & 03,56 & 08,8 & 01,89 & 049 & 055 & 028 \\
\hline HE 80/60 - 0.5\%, CP2 & 0,15 & 31,0 & 6,44 & 21,9 & 04,58 & 14,7 & 03,11 & 066 & 071 & 047 \\
\hline HE 80/60 - 0.5\%, CP3 & 0,12 & 27,7 & 5,76 & 30,2 & 06,27 & 33,6 & 06,96 & 111 & 109 & 121 \\
\hline HE 80/60 - 1\%, CP1 & 0,13 & 27,0 & 5,61 & 38,8 & 08,03 & 29,5 & 06,13 & 123 & 144 & 110 \\
\hline HE 80/60 - 1\%, CP2 & 0,14 & 29,5 & 6,13 & 43,5 & 08,99 & 40,7 & 08,41 & 171 & 147 & 138 \\
\hline HE 80/60 - 1\%, CP3 & 0,15 & 29,5 & 6,12 & 39,9 & 08,25 & 41,1 & 08,50 & 151 & 135 & 139 \\
\hline HE 80/60 - 2\%, CP1 & 0,12 & 23,2 & 4,85 & 45,8 & 09,46 & 46,7 & 09,65 & 196 & 197 & 201 \\
\hline HE 80/60 - 2\%, CP2 & 0,12 & 23,5 & 4,90 & 46,0 & 09,50 & 45,3 & 09,36 & 194 & 196 & 193 \\
\hline HE 80/60 - 2\%, CP3 & 0,12 & 23,9 & 4,98 & 50,7 & 10,47 & 38,3 & 07,92 & 174 & 212 & 160 \\
\hline TW 50/25 - 0.5\%, CP1 & 0,13 & 26,3 & 5,47 & 22,5 & 04,69 & 07,7 & 01,66 & 048 & 086 & 029 \\
\hline TW 50/25 - 0.5\%, CP2 & 0,14 & 27,9 & 5,80 & 20,5 & 04,29 & 10,8 & 02,31 & 054 & 073 & 039 \\
\hline TW 50/25 - 0.5\%, CP3 & 0,14 & 25,4 & 5,28 & 24,1 & 05,02 & 08,8 & 01,89 & 052 & 095 & 034 \\
\hline TW 50/25 - 1\%, CP1 & 0,12 & 26,6 & 5,53 & 32,8 & 06,80 & 11,8 & 02,50 & 068 & 123 & 044 \\
\hline TW 50/25 - 1\%, CP2 & 0,13 & 25,6 & 5,34 & 23,7 & 04,93 & 14,2 & 03,01 & 066 & 092 & 056 \\
\hline TW 50/25 - 1\%, CP3 & 0,14 & 27,1 & 5,64 & 22,4 & 04,67 & 13,0 & 02,74 & 064 & 083 & 048 \\
\hline TW 50/25 - 2\%, CP1 & 0,13 & 29,4 & 6,12 & 62,3 & 12,83 & 66,1 & 13,62 & 266 & 212 & 225 \\
\hline TW 50/25 - 2\%, CP2 & 0,13 & 28,0 & 5,82 & 44,9 & 09,27 & 40,7 & 08,41 & 177 & 160 & 145 \\
\hline TW 50/25 - 2\%, CP3 & 0,13 & 27,6 & 5,75 & 48,9 & 10,10 & 33,9 & 07,02 & 141 & 177 & 122 \\
\hline
\end{tabular}

Obs.: A sigla CPN refere-se ao corpo de prova ou exemplar de número $\mathrm{N}$. 
Tabela 21 - Resumo dos resultados individuais à flexão de painéis circulares

\begin{tabular}{|c|c|c|c|c|c|c|c|c|c|}
\hline \multicolumn{10}{|c|}{$\begin{array}{l}\text { Valores característicos ir } \\
\text { Resultados de carga e deflexão de base } \\
\text { de painéis circulares sob flexão }\end{array}$} \\
\hline \multirow[b]{2}{*}{$\begin{array}{l}\text { Exemplar / corpo-de- } \\
\text { prova }\end{array}$} & \multirow[b]{2}{*}{$\begin{array}{l}\delta_{p} \\
\mathrm{kN}\end{array}$} & \multirow[b]{2}{*}{$\begin{array}{l}P_{p} \\
\mathrm{kN}\end{array}$} & \multirow[b]{2}{*}{$\begin{array}{c}P_{w, 0,1} \\
\mathrm{kN}\end{array}$} & \multirow[b]{2}{*}{$\begin{array}{l}P_{5} \\
\mathrm{kN}\end{array}$} & \multirow[b]{2}{*}{$\begin{array}{c}P_{10} \\
\mathrm{kN}\end{array}$} & \multirow[b]{2}{*}{$\begin{array}{c}T_{40} \\
\mathrm{~kJ}\end{array}$} & \multicolumn{3}{|c|}{ valores absolutos } \\
\hline & & & & & & & $\begin{array}{c}P_{w} / P_{p} \\
\%\end{array}$ & $\begin{array}{c}P_{5} / P_{p} \\
\%\end{array}$ & $\begin{array}{c}P_{10} / P_{p} \\
\%\end{array}$ \\
\hline CAA - 0\%, CP1 & 0,62 & 27,0 & - & - & - & - & - & - & - \\
\hline CAA - 0\%, CP2 & 1,03 & 27,1 & - & - & - & - & - & - & - \\
\hline CAA - 0\%, CP3 & 0,99 & 27,9 & - & - & - & - & - & - & - \\
\hline HE $45 / 30-0.5 \%$, CP1 & 0,92 & 26,7 & 26,6 & 16,5 & 10,7 & 248 & 100 & 062 & 040 \\
\hline HE $45 / 30-0.5 \%$, CP2 & 0,72 & 28,3 & 28,1 & 22,6 & 15,4 & 326 & 099 & 080 & 054 \\
\hline HE $45 / 30-0.5 \%$, CP3 & 0,97 & 31,1 & 30,4 & 24,3 & 15,3 & 336 & 098 & 078 & 049 \\
\hline HE $45 / 30-1 \%$, CP1 & 0,86 & 34,1 & 32,9 & 38,2 & 20,6 & 442 & 097 & 112 & 061 \\
\hline HE 45/30 - 1\%, CP2 & 0,87 & 30,3 & 31,1 & 14,1 & 3,6 & 185 & 103 & 046 & 012 \\
\hline HE 45/30 - 1\%, CP3 & 0,77 & 30,3 & 28,8 & 32,3 & 12,1 & 325 & 095 & 107 & 040 \\
\hline HE $45 / 30-2 \%$, CP1 & 0,90 & 44,1 & 41,8 & 64,1 & 41,3 & 786 & 095 & 145 & 094 \\
\hline HE 45/30 - 2\%, CP2 & 0,79 & 47,8 & 39,7 & 60,5 & 29,6 & 668 & 083 & 126 & 062 \\
\hline HE 45/30 - 2\%, CP3 & 1,00 & 45,9 & 42,1 & 64,8 & 44,7 & 845 & 092 & 141 & 097 \\
\hline HE 80/60 - 2\%, CP1 & 0,98 & 40,8 & 36,7 & 71,0 & 79,8 & 1267 & 090 & 174 & 196 \\
\hline HE 80/60 - 2\%, CP2 & 0,87 & 41,5 & 35,2 & 69,3 & 64,8 & 1109 & 085 & 167 & 156 \\
\hline HE $80 / 60-2 \%$, CP3 & 0,92 & 41,4 & 35,7 & 67,6 & 62,1 & 1058 & 086 & 163 & 150 \\
\hline TW 50/25 - 2\%, CP1 & 1,04 & 39,2 & 32,9 & 58,3 & 35,4 & 660 & 084 & 149 & 090 \\
\hline TW 50/25 - 2\%, CP2 & 0,94 & 46,3 & 42,5 & 73,5 & 51,3 & 952 & 092 & 159 & 111 \\
\hline TW 50/25 - 2\%, CP3 & 0,88 & 47,3 & 42,6 & 73,6 & 60,8 & 1079 & 090 & 156 & 128 \\
\hline
\end{tabular}


7.2

ANEXO II - Fotomontagem dos corpos de prova ensaiados

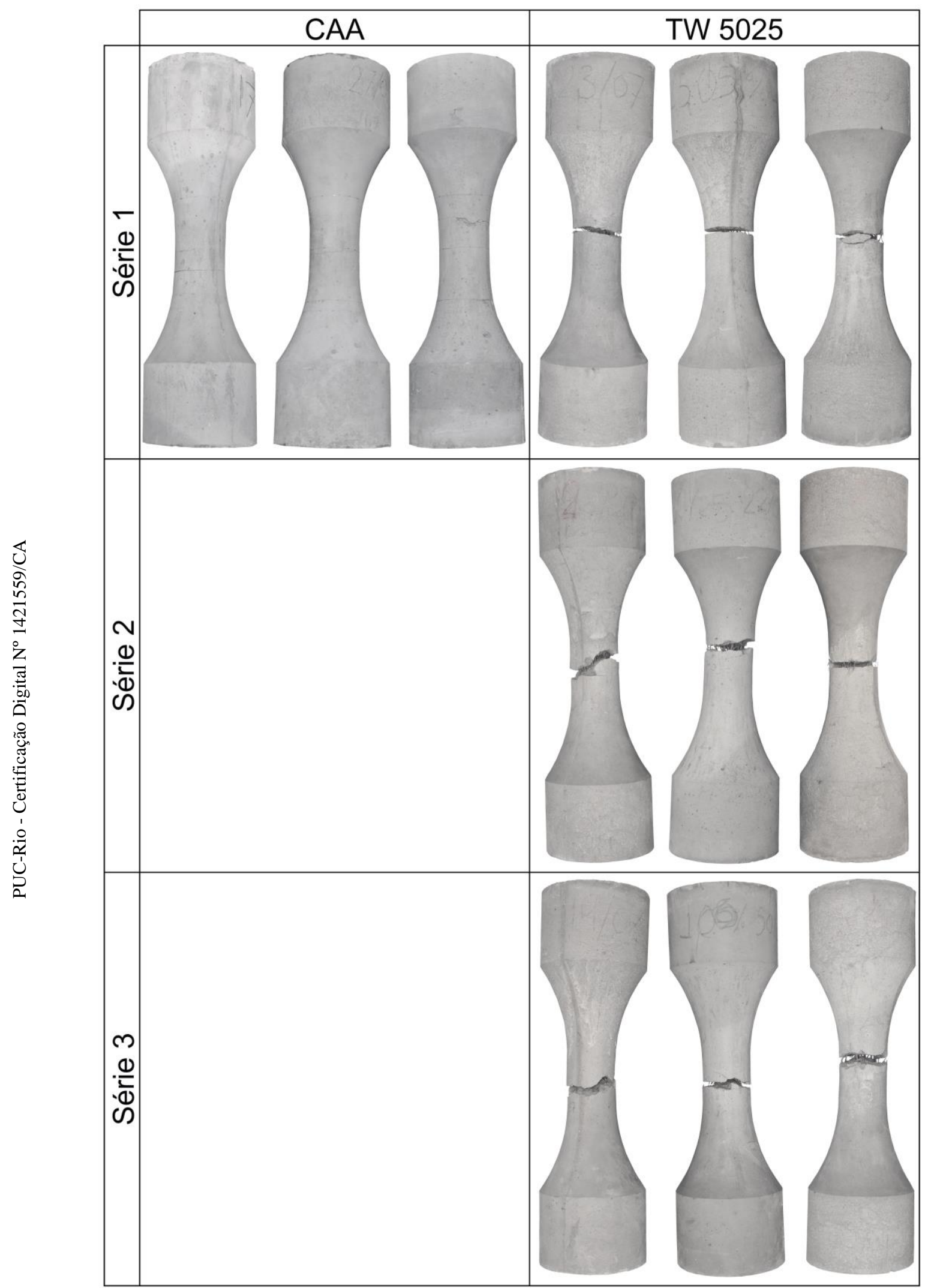

Figura 71 - Fotomontagem dos corpos de prova tipo dog bone shaped ensaiados à tração direta: séries CAA - 0\% e TW 50/25 


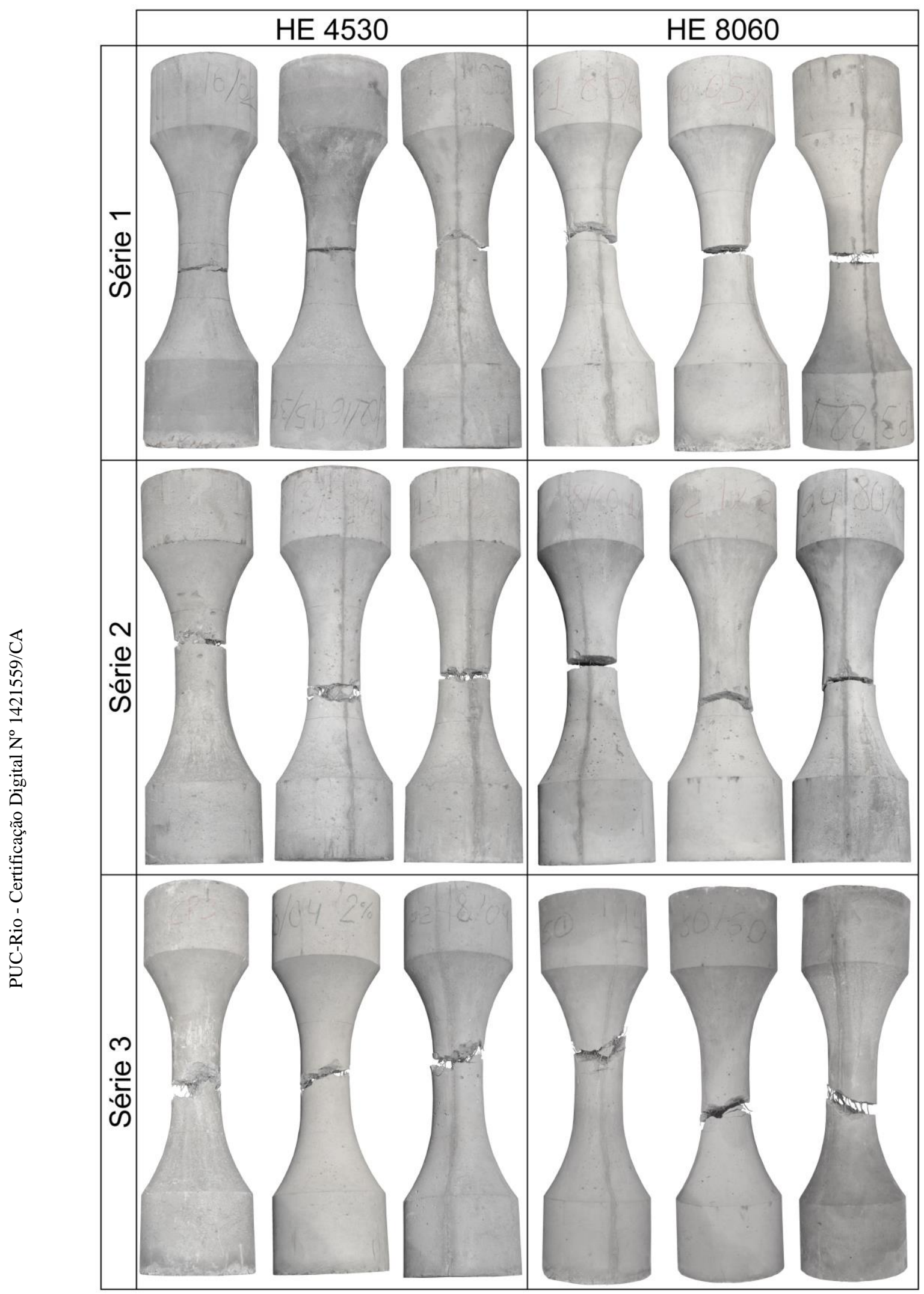

Figura 72 - Fotomontagem dos corpos de prova tipo dog bone shaped ensaiados à tração direta: séries HE 45/30 e HE 80/60 


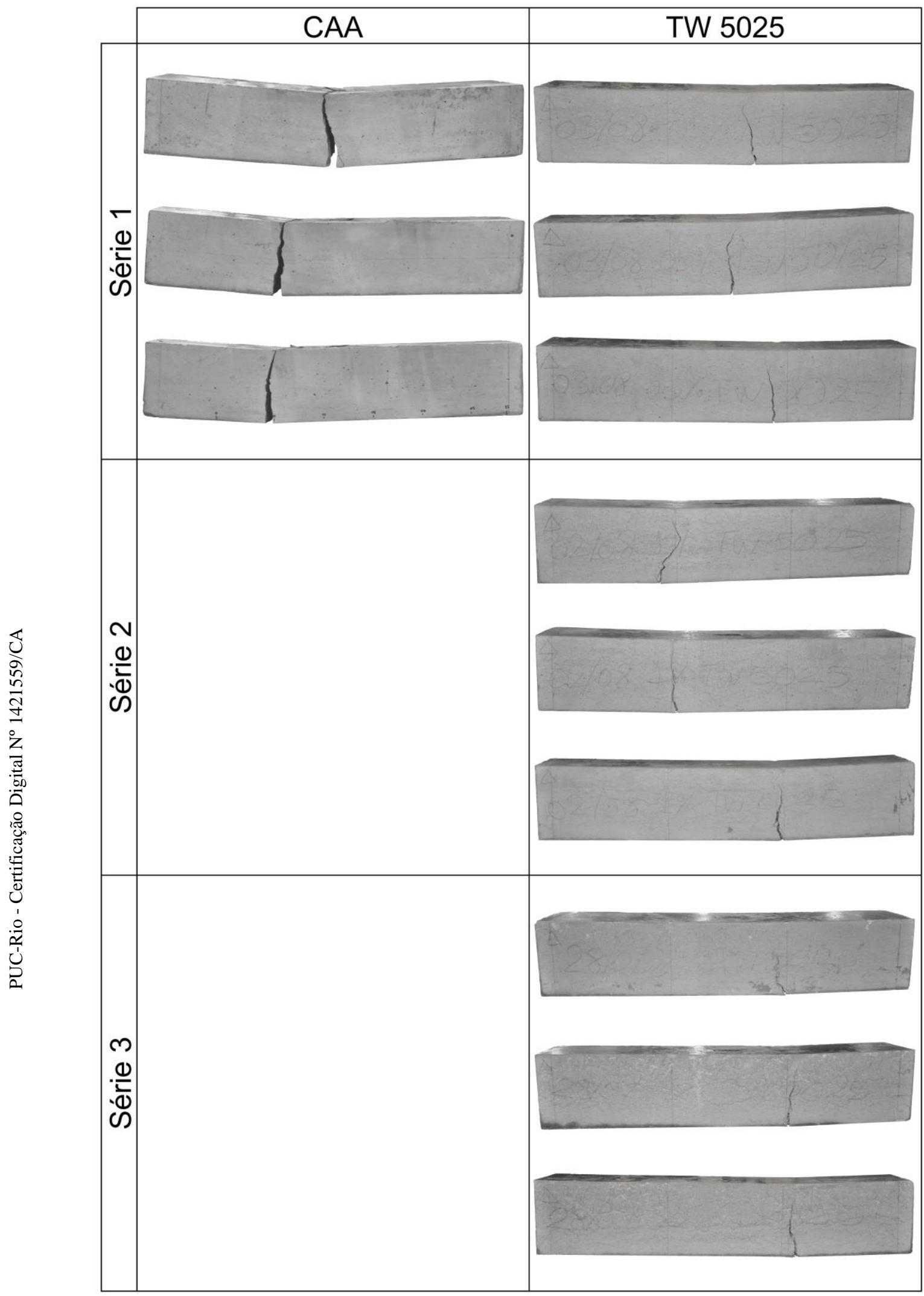

Figura 73 - Fotomontagem dos corpos de prova prismáticos ensaiados à flexão: séries CAA - 0\% e TW 50/25 


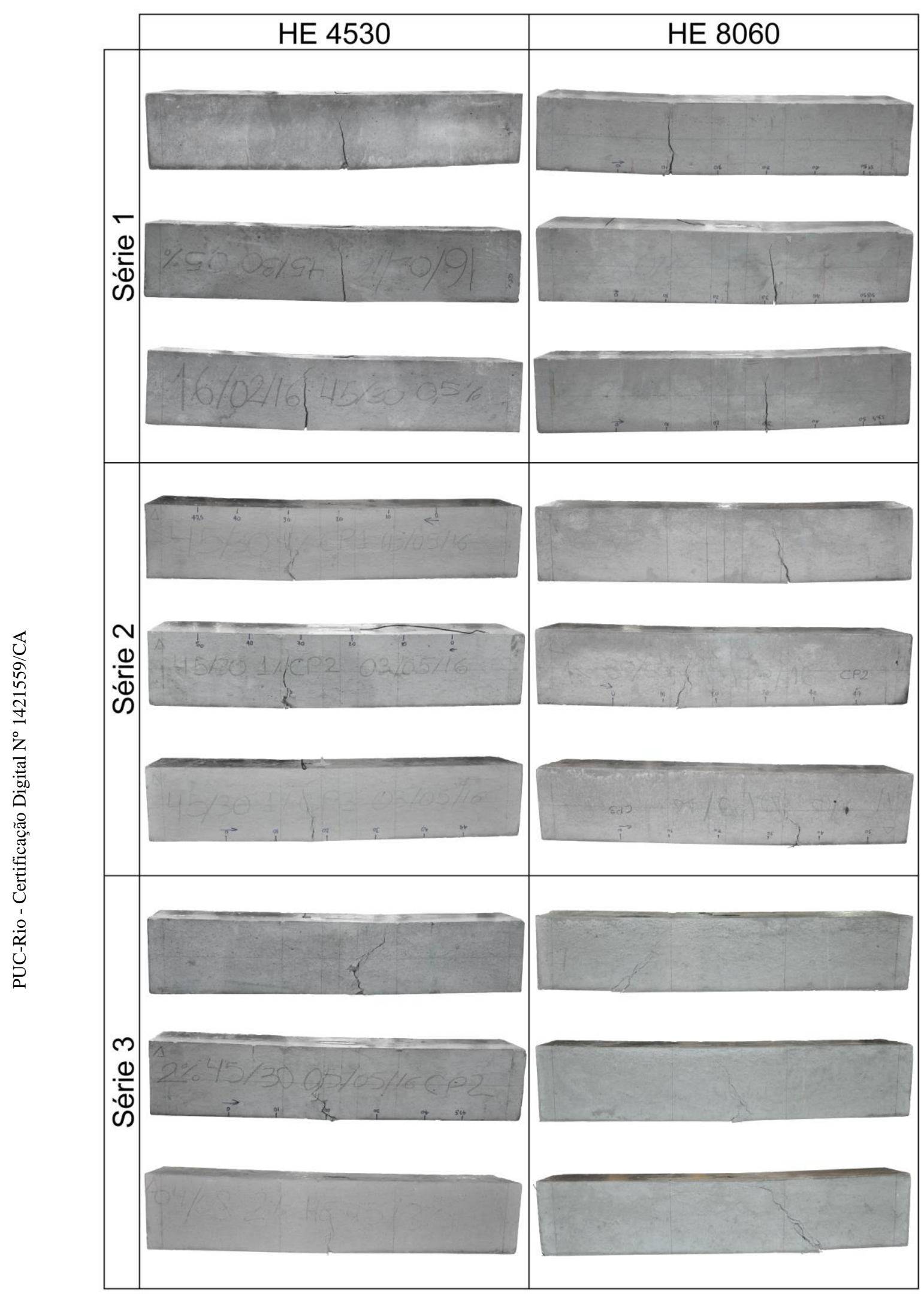

Figura 74 - Fotomontagem dos corpos de prova prismáticos ensaios à flexão: séries HE 45/30 e HE 80/60 


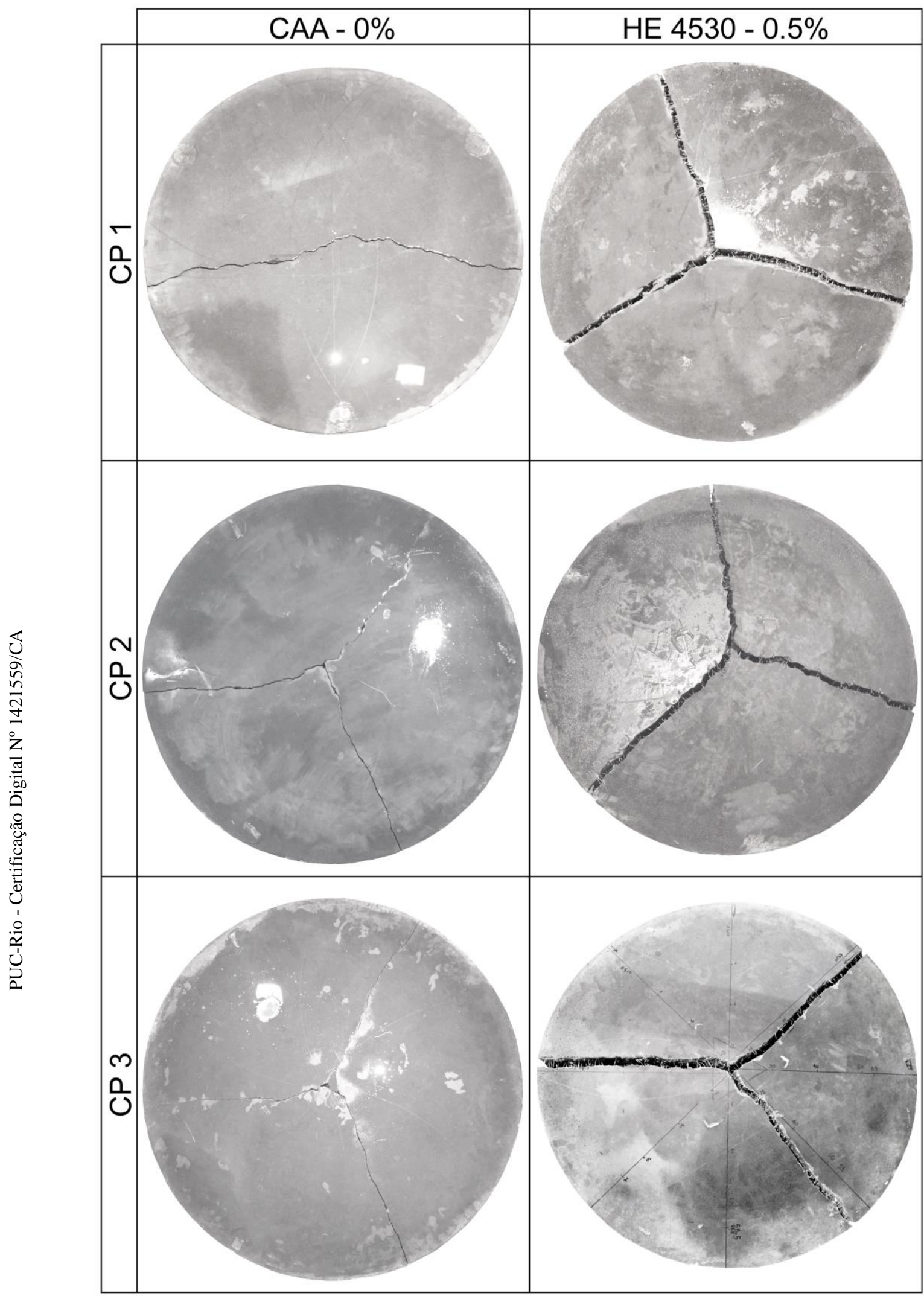

Figura 75 - Fotomontagem dos painéis circulares ensaiados à flexão: séries CAA $0 \%$ e HE $45 / 30-0,5 \%$ 


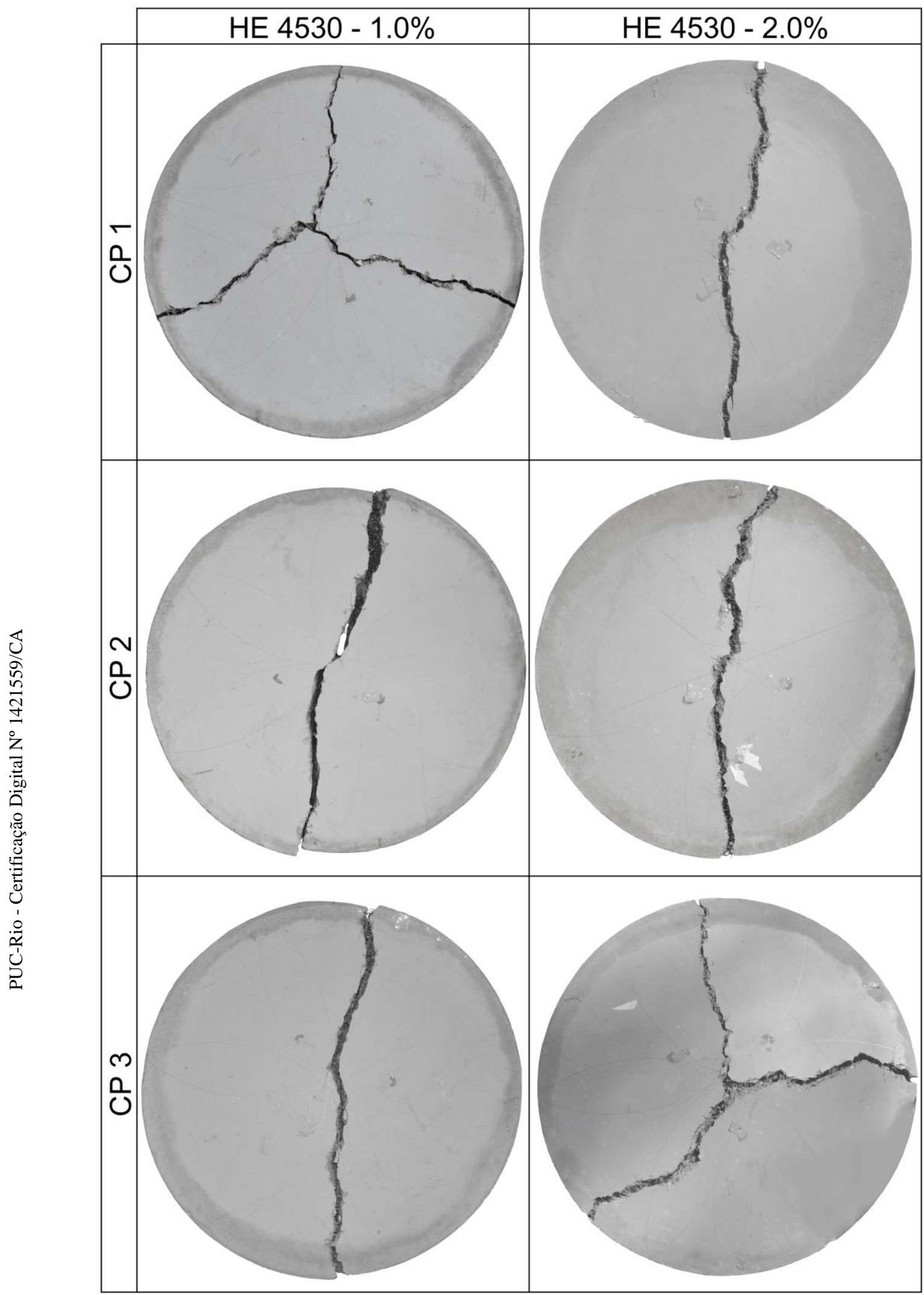

Figura 76 - Fotomontagem dos painéis circulares ensaiados à flexão: séries HE $45 / 30-1,0 \%$ e HE $45 / 30-2,0 \%$ 


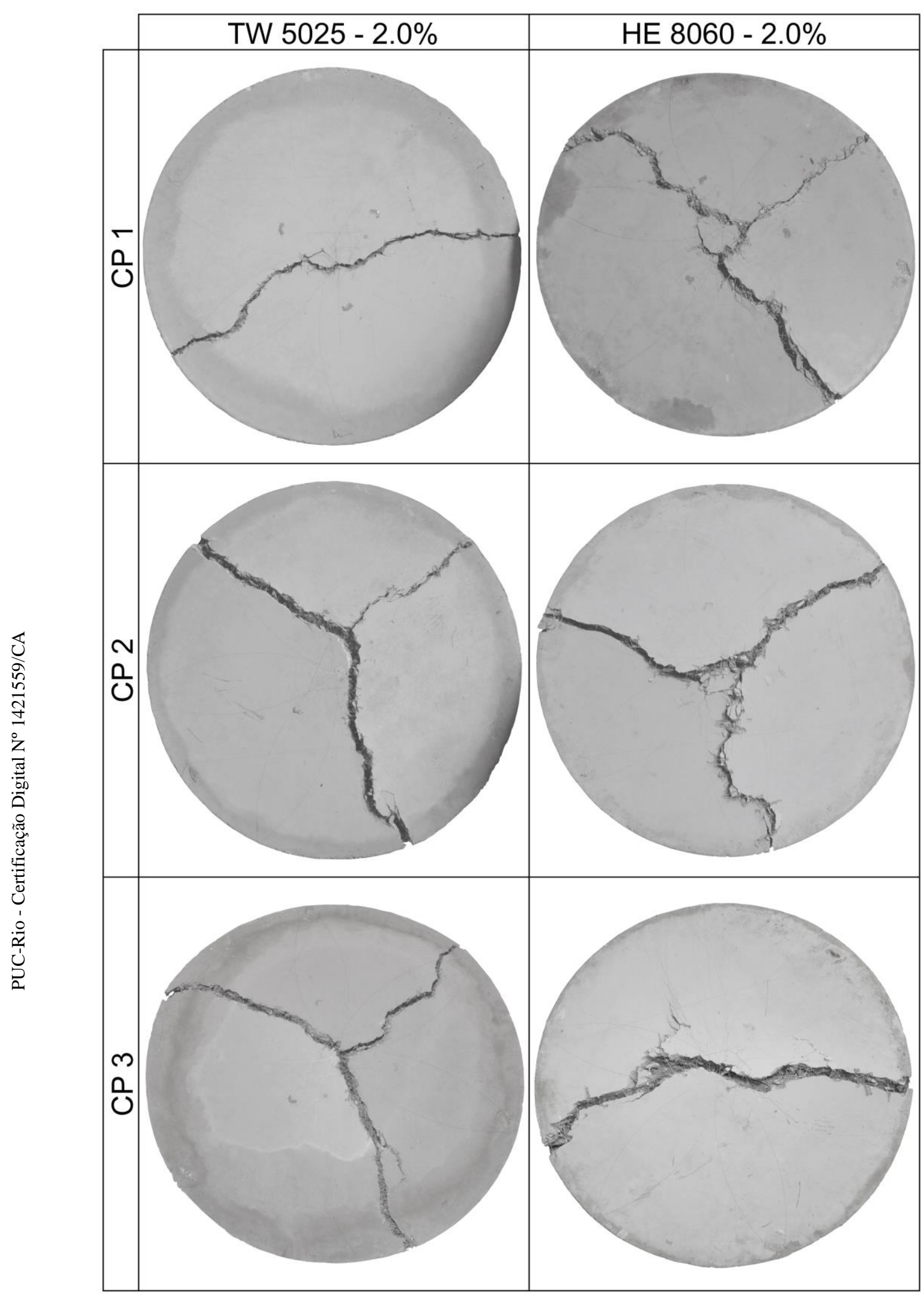

Figura 77 - Fotomontagem dos painéis circulares ensaiados à flexão: séries TW $50 / 25-2,0 \%$ e HE $80 / 50-2,0 \%$ 